UNIVERSIDADE DE SÃO PAULO

INSTITUTO DE QUÍMICA DE SÃO CARLOS

EXTRAÇÃO ASSISTIDA POR MICRO-ONDAS NO PREPARO DE UM BIOERBICIDA A PARTIR DAS FOLHAS DA CANAVALIA ENSIFORMIS: APLICAÇÃO EM PLANTAS INVASORAS NA CULTURA DE SOJA CONVENCIONAL E AS CONSEQUÊNCIAS NO SOLO

ALUNO: Darlan Ferreira da Silva

ORIENTADORA: Profa. Dra. Maria Olímpia de Oliveira Rezende 


\section{EXTRAÇÃO ASSISTIDA POR MICRO-ONDAS NO PREPARO DE UM BIOERBICIDA A PARTIR DAS FOLHAS DA CANAVALIA ENSIFORMIS: APLICAÇÃO EM PLANTAS INVASORAS NA CULTURA DE SOJA CONVENCIONAL E AS CONSEQUÊNCIAS NO SOLO}

Tese apresentada ao Instituto de Química de São Carlos da Universidade de São Paulo como parte dos requisitos para obtenção do título de Doutor em Química (Química Analítica).

Área de concentração: Química Analítica e Inorgânica Orientadora: Profa. Dra. Maria Olímpia de Oliveira Rezende

\section{Exemplar revisado}

O exemplar original encontra-se em acervo na Biblioteca do IQSC-USP 
Ficha catalográfica elaborada pela Seção de Referência e Atendimento ao Usuário do SBI/IQSC

Silva, Darlan Ferreira da

Extração assistida por micro-ondas no preparo de um bioerbicida a partir das folhas da canavalia ensiformis: aplicação em plantas invasoras na cultura de soja convencional e as consequências no solo / Darlan Ferreira da Silva. São Carlos, 2016.

$207 \mathrm{f}$.

Tese (Doutorado em Química Analítica e Inorgânica) - Instituto de Química de São Carlos / Universidade de São Paulo, 2016.

Edição revisada

Orientadora: Profa. Dra. Maria Olímpia de Oliveira Rezende

1.Soja. 2. Solos. 3. Compostos fenólicos. 4. Plantas invasoras. I. Título 


\section{Agradecimentos}

À Profa Dra. Maria Olímpia, pela oportunidade de desenvolver este trabalho em seu laboratório e principalmente pela confiança e valiosa orientação;

À Maria Diva Landgraf, pelo carinho e todo ensinamento; Aos colegas do Laboratório de Química Ambiental (LQA), Leandro, Rachide, Fernanda e Lívia pelo agradável convívio e pela troca de ideias e experiências de vida;

À Letícia Furlan pela ajuda durante todas as etapas de análise do solo e às alunas de iniciação científica Paula Barione (Loló Barione), Rut Naiara, Rhaissa e Ticiane por todo e qualquer auxílio;

Agradeço ao Adilson Junior da Embrapa Soja de Londrina-PR e a Marcilene Bueno da Fazenda Santa Inês, Ourinhos-SP, por gentilmente cederem as sementes de soja convencional para a realização do meu trabalho;

Ao técnico Oscar dos Santos Neto, do Departamento de Geotecnia, pela disposição e ajuda nas coletas do solo;

À minha família, pai, mãe e irmão que sempre torceram por mim;

À Nilia, por participar de mais uma jornada de experiências em minha vida;

Ao IQSC-USP pelo suporte institucional;

À FAPEMA pela concessão da bolsa. 


\section{RESUMO}

Vários compostos químicos são usados para o controle de pragas e doenças na agricultura com a finalidade de aumentar a produtividade. É de conhecimento científico que tais compostos afetam negativamente a saúde humana e animal por meio da contaminação dos alimentos e do meio ambiente. Assim, o uso de substâncias obtidas da própria natureza para o combate de pragas e plantas invasoras é uma alternativa para o controle e, consequente, prevenção da contaminação ambiental. Neste trabalho foram avaliados os extratos aquosos das folhas da leguminosa feijão-de-porco (Canavalia ensiformis) como bioerbicida pós-emergente aplicado no controle de plantas invasoras em cultura de soja e seus efeitos no solo. Salienta-se que não há informações sobre os efeitos desses bioerbicida no solo. Os compostos fenólicos, em especial os ácidos fenólicos, têm ação inibitória no crescimento de plantas invasoras. O processo de extração dos compostos fenólicos foi feito em um sistema de digestão por microondas, com aproximadamente $2 \mathrm{~g}$ de material vegetal seco, seguida de injeção cromatográfica. Para otimização do procedimento de extração via micro-ondas os parâmetros avaliados foram: tempo de irradiação, temperatura e rampa aplicada. Foram realizadas determinações cromatográficas para identificação e quantificação dos compostos fenólicos: rutina, ácido clorogênico, ácido ferúlico e naringenina presentes nas folhas do feijão-de-porco por HPLCUV, mediante metodologia de extração por micro-ondas. Todo o trabalho foi desenvolvido de acordo com os requisitos de gestão da qualidade referentes às normas NBR ISO/IEC 17025 e BPL.

Palavras-chave: bioerbicidas, plantas invasoras, Canavalia ensiformis, Emilia sonchifolia, Sida spinosa, extração assistida por micro-ondas, solo, soja, HPLC-UV, compostos fenólicos. 


\begin{abstract}
Several chemical compounds are used for pest and disease control in agriculture in order to increase productivity. It is well know that such pesticides adversely affect human and animal health through contamination by food and environment. Thus, the use of substances obtained from nature itself to combat pests and weeds is an alternative for the control of those and, consequently, prevent environmental contamination. This work were assessed aqueous extracts of jack bean leaves (Canavalia ensiformis) as a post-emergent bioherbicide applied in weed control in soybean crops and its effects on the soil. It is noteworthy there is not information on the effects of these bioherbicides on the soil. Phenolics compounds, notably, phenolics acids, have inhibitory action on the growth of weeds. The process of extraction of phenolic compounds was carried out in a digestion system by microwave, using approximately $2 \mathrm{~g}$ dry plant material, followed by chromatographic injection. For optimization of the extraction procedure by microwave-assisted extraction the factors evaluated were irradiation time, temperature and ramp time. Chromatographic determinations were performed for identification and quantification of the phenolic compounds: rutin, chlorogenic acid, ferulic acid and naringenin present in the Canavalia ensiformis leaves by HPLC-UV, through microwave extraction methodology. All the study was developed in compliance with the quality management concepts covered in NBR ISO/IEC 17025 and GLP.
\end{abstract}

Keywords: bioherbicides, weeds, Canavalia ensiformis, Emilia sonchifolia, Sida spinosa, microwave-assisted extraction, soil, soybean, HPLC-UV, phenolic compounds. 


\section{LISTA DE FIGURAS}

Figura 1- Sementes de feijão-de-porco (Canavalia ensiformis) ..........................................23

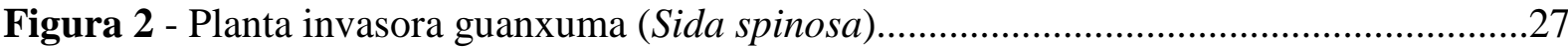

Figura 3 - Planta invasora Falsa serralha (Emilia sonchifolia) ............................................27

Figura 4 - Estruturas moleculares dos compostos fenólicos selecionados..............................30

Figura 5 - Estrutura molecular dos ácidos hidroxibenzóicos.................................................32

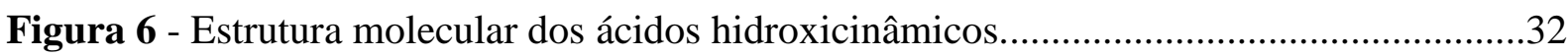

Figura 7 - Estrutura genérica das moléculas dos flavonoides..............................................33

Figura 8 - Estrutura genérica das maiores classes dos flavonoides......................................33

Figura 9 - Plantação do feijão-de-porco (Canavalia ensiformis)..........................................64

Figura 10 - Distribuição do experimento em casa de vegetação.............................................64

Figura 11 - Etapas para o preparo dos extratos aquosos e obtenção do bioerbicida para

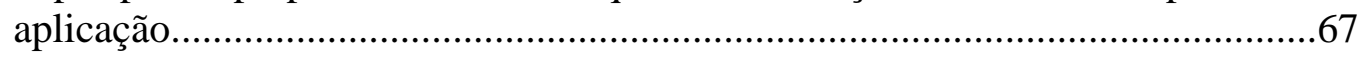

Figura 12 - Etapas do experimento em casa de vegetação..................................................69

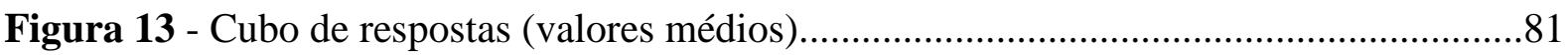

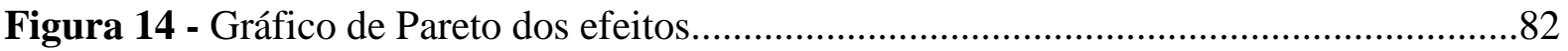

Figura 15 - Valores preditos pelo modelo ajustado e valores observados experimentalmente.

Figura 16 - Resíduos e valores preditos pelo modelo ajustado

Figura 17 - Gráfico de superfície de resposta mostrando os efeitos das variáveis tempo (min) $\mathrm{x}$ rampa (min) sobre a resposta (concentração em $\mathrm{mg} \mathrm{g}^{-1}$ ) obtida para o composto ácido ferúlico.

Figura 18 - Gráfico de superfície de resposta mostrando os efeitos das variáveis rampa (min) $\mathrm{x}$ temperatura $\left({ }^{\circ} \mathrm{C}\right.$ ) sobre a resposta (concentração em $\mathrm{mg} \mathrm{g}^{-1}$ ) obtida para $\mathrm{o}$ composto ácido ferúlico

Figura 19 - Gráfico de superfície de resposta mostrando os efeitos das variáveis temperatura $\left({ }^{\circ} \mathrm{C}\right) \mathrm{x}$ tempo (min) sobre a resposta (concentração em $\mathrm{mg} \mathrm{g}^{-1}$ ) obtida para o composto ácido ferúlico. 
Figura 20 - Cromatograma dos compostos extraídos via extração assistida por micro-ondas. Condições cromatográficas: volume de injeção de $20 \mu \mathrm{L}$; fase móvel $2 \%$ ácido acético glacial em água + metanol, 75:25 (v/v); fluxo da fase móvel 1,2 mL min ${ }^{1}$, temperatura da coluna: ambiente; detector: UV-Vis (282 nm). Picos: (1) rutina, (2) ácido ferúlico, (3) ácido clorogênico e (4) naringenina.

Figura 21 - Curva analítica ácido clorogênico. Condições cromatográficas: volume de injeção de $20 \mu \mathrm{L}$; fase móvel $2 \%$ ácido acético glacial em água + metanol, 75:25 (v/v); fluxo da fase móvel 1,2 $\mathrm{mL} \mathrm{min}^{-1}$, temperatura da coluna: ambiente; detector: $\mathrm{UV}-\mathrm{Vis}(282 \mathrm{~nm})$

Figura 22 - Curva analítica rutina. Condições cromatográficas: volume de injeção de $20 \mu \mathrm{L}$; fase móvel $2 \%$ ácido acético glacial em água + metanol, 75:25 (v/v); fluxo da fase móvel 1,2 $\mathrm{mL} \mathrm{min}^{-1}$, temperatura da coluna: ambiente; detector: $\mathrm{UV}-\mathrm{V}$ is $(282 \mathrm{~nm})$

Figura 23 - Curva analítica naringenina. Condições cromatográficas: volume de injeção de $20 \mu \mathrm{L}$; fase móvel $2 \%$ ácido acético glacial em água + metanol, 75:25 (v/v);

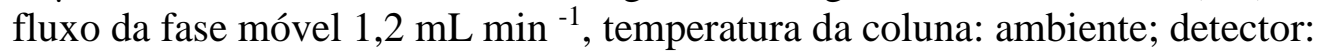
$\mathrm{UV}-\mathrm{Vis}(282 \mathrm{~nm})$

Figura 24 - Curva analítica ácido ferúlico. Condições cromatográficas: volume de injeção de $20 \mu \mathrm{L}$; fase móvel $2 \%$ ácido acético glacial em água + metanol, 75:25 (v/v); fluxo da fase móvel 1,2 $\mathrm{mL} \mathrm{min}^{-1}$, temperatura da coluna: ambiente; detector: UV-Vis $(282 \mathrm{~nm})$

Figura 25 - Cromatogramas dos extratos aquosos obtidos após MAE. (1) Ácido clorogênico. Concentrações de fortificação de 2,5 e $10 \mathrm{mg}$. L $\mathrm{L}^{-1}$. Condições cromatográficas: volume de injeção de $20 \mu \mathrm{L}$; fase móvel $2 \%$ ácido acético glacial em água + metanol, 75:25 (v/v); fluxo da fase móvel 1,2 $\mathrm{mL} \mathrm{min}^{-1}$, temperatura da coluna: ambiente; detector: UV-Vis (282 nm). Tempo de retenção: 16,25 min. .99

Figura 26 - Cromatogramas dos extratos aquosos obtidos após MAE. (1) Naringenina. Concentrações de fortificação de 2,5 e $10 \mathrm{mg}$. $\mathrm{L}^{-1}$. Condições cromatográficas: volume de injeção de $20 \mu \mathrm{L}$; fase móvel $2 \%$ ácido acético glacial em água + metanol, 75:25 (v/v); fluxo da fase móvel 1,2 $\mathrm{mL} \mathrm{min}^{-1}$, temperatura da coluna: ambiente; detector: UV-Vis $(282 \mathrm{~nm})$. Tempo de retenção: 22,50 min. 100

Figura 27 - Cromatogramas dos extratos aquosos obtidos após MAE. (1) Rutina. Concentrações de fortificação de 2,5 e $10 \mathrm{mg}$. $\mathrm{L}^{-1}$. Condições cromatográficas: volume de injeção de $20 \mu \mathrm{L}$; fase móvel $2 \%$ ácido acético glacial em água + metanol, 75:25 (v/v); fluxo da fase móvel 1,2 $\mathrm{mL} \mathrm{min}^{-1}$, temperatura da coluna: ambiente; detector: UV-Vis (282 nm). Tempo de retenção: 2,85 min.

Figura 28 - Cromatogramas dos extratos aquosos obtidos após MAE. (1) Ácido ferúlico. Concentrações de fortificação: (a) extrato; (b) $2 \mathrm{mg}$. L ${ }^{-1}$; (c) $5 \mathrm{mg} . \mathrm{L}^{-1}$; (d) 10 mg. $\mathrm{L}^{-1}$. Condições cromatográficas: volume de injeção de $20 \mu \mathrm{L}$; fase móvel 2 $\%$ ácido acético glacial em água + metanol, 75:25 (v/v); fluxo da fase móvel 1,2 $\mathrm{mL} \min ^{-1}$, temperatura da coluna: ambiente; detector: UV-Vis $(282 \mathrm{~nm})$. Tempo de retenção: 10,61 min. 
Figura 29 - Relação entre a concentração recuperada e a concentração de fortificação, com níveis variando entre 2,0 e $10,0 \mathrm{mg}$. $\mathrm{L}^{-1}$

Figura 30 - Efeito do bioerbicida extraído das folhas do feijão-de-porco na concentração de $200 \mathrm{~g} \mathrm{~L}^{-1}$ na erva daninha Emilia sonchifolia. (1) sem aplicação, (2) 24 h após aplicação, (3) 5 dias após aplicação................................................................107

Figura 31 - Desenvolvimento da planta invasora Emilia sonchifolia. 109

Figura 32 - Vaso de referência utilizados nos experimentos com a planta Emilia sonchifolia (à esquerda) e a soja (à direita)....

Figura 33 - Sintoma de fitotoxicidade causada pela ação de 1,5 mL do extrato contendo o bioerbicida nas folhas da soja, 24 h após aplicação, em concentração de 100 g L1

Figura 34 - Plantas de soja em desenvolvimento 35 dias após aplicação do bioerbicida, depois de interrompida a aplicação direta de $1,5 \mathrm{~mL}$ do extrato contendo o bioerbicida na concentração de $100 \mathrm{~g} \mathrm{~L}^{-1} \mathrm{em}$ suas folhas.

Figura 35 - Curva de distribuição granulométrica do solo

Figura 36 - Média das temperaturas e precipitação durante o experimento com a planta invasora Emília sonchifolia. Média t máxima (média das temperaturas máximas). Média t mínima (média das temperaturas mínimas).

Figura 37 - $\mathrm{pH}$ em $\mathrm{CaCl}_{2}$ do solo após incorporação do bioerbicida, na $1^{\mathrm{a}}, 2^{\mathrm{a}}, 3^{\mathrm{a}}, 4^{\mathrm{a}}$ e $5^{\mathrm{a}}$ aplicação. Médias seguidas pela mesma letra na coluna não diferem significativamente entre si pelo teste de Tukey $(\mathrm{P}<0,05)$.

Figura 38 - Teor de cálcio (a), teor de potássio (b) do solo após incorporação do bioerbicida, na $1^{\mathrm{a}}, 2^{\mathrm{a}}, 3^{\mathrm{a}}, 4^{\mathrm{a}}$ e $5^{\mathrm{a}}$ aplicação. Médias seguidas pela mesma letra na coluna não diferem significativamente entre si pelo teste de Tukey $(\mathrm{P}<0,05)$.

Figura 39 - Fósforo disponível no solo após incorporação do bioerbicida, na $1^{\mathrm{a}}, 2^{\mathrm{a}}, 3^{\mathrm{a}}, 4^{\mathrm{a}}$ e $5^{\mathrm{a}}$ aplicação. Médias seguidas pela mesma letra na coluna não diferem significativamente entre si pelo teste de Tukey $(\mathrm{P}<0,05)$.

Figura 40 - Nitrogênio total no solo após incorporação do bioerbicida, na $1^{\mathrm{a}}, 2^{\mathrm{a}}, 3^{\mathrm{a}}, 4^{\mathrm{a}}$ e $5^{\mathrm{a}}$ aplicação. Médias seguidas pela mesma letra na coluna não diferem significativamente entre si pelo teste de Tukey $(\mathrm{P}<0,05)$.

Figura 41 - Vagem da planta de soja

Figura 42 - Amarelecimento das folhas de soja.

Figura 43 - Vagem da planta de soja (estágio de pré eclosão das sementes).

Figura 44 - Plantas de soja aos 76 dias do experimento (liberação das sementes). 
Figura 45 - Acidez trocável no solo após incorporação do bioerbicida, na $1^{\mathrm{a}}, 2^{\mathrm{a}}, 3^{\mathrm{a}}, 4^{\mathrm{a}}$ e $5^{\mathrm{a}}$ aplicação. Médias seguidas pela mesma letra na coluna não diferem significativamente entre si pelo teste de Tukey $(\mathrm{P}<0,05)$.

Figura 46 - Capacidade de troca catiônica no solo após incorporação do bioerbicida, na $1^{\mathrm{a}}, 2^{\mathrm{a}}$, $3^{\mathrm{a}}, 4^{\mathrm{a}}$ e $5^{\mathrm{a}}$ aplicação. Médias seguidas pela mesma letra na coluna não diferem significativamente entre si pelo teste de Tukey $(\mathrm{P}<0,05)$.

Figura 47 - Teor de carbono orgânico no solo após incorporação do bioerbicida, na $1^{\mathrm{a}}, 2^{\mathrm{a}}, 3^{\mathrm{a}}$, $4^{\mathrm{a}}$ e $5^{\mathrm{a}}$ aplicação. Médias seguidas pela mesma letra na coluna não diferem significativamente entre si pelo teste de Tukey $(\mathrm{P}<0,05)$.

Figura 48 - Média das temperaturas e precipitação durante o experimento com a planta invasora Sida spinosa. Média t máxima (média das temperaturas máximas). Média t mínima (média das temperaturas mínimas).

Figura 49 - pH $\left(\mathrm{CaCl}_{2}\right)$ no solo após incorporação do bioerbicida, na $1^{\mathrm{a}}, 2^{\mathrm{a}}, 3^{\mathrm{a}}$ e $4^{\mathrm{a}}$ aplicação. Médias seguidas pela mesma letra na coluna não diferem significativamente entre si pelo teste de Tukey $(P<0,05)$...

Figura 50 - Capacidade de troca catiônica no solo após incorporação do bioerbicida, na $1^{\mathrm{a}}, 2^{\mathrm{a}}$, $3^{\mathrm{a}}$ e $4^{\mathrm{a}}$ aplicação. Médias seguidas pela mesma letra na coluna não diferem significativamente entre si pelo teste de Tukey $(P<0,05)$.

Figura 51 - Teor de cálcio no solo após incorporação do bioerbicida, na $1^{\mathrm{a}}, 2^{\mathrm{a}}, 3^{\mathrm{a}}$ e $4^{\mathrm{a}}$ aplicação. Médias seguidas pela mesma letra na coluna não diferem significativamente entre si pelo teste de Tukey $(P<0,05)$.

Figura 52 - Teor de potássio no solo após incorporação do bioerbicida, na $1^{\mathrm{a}}, 2^{\mathrm{a}}, 3^{\mathrm{a}}$ e $4^{\mathrm{a}}$ aplicação. Médias seguidas pela mesma letra na coluna não diferem significativamente entre si pelo teste de Tukey $(P<0,05)$

Figura 53 - Fósforo disponível no solo após incorporação do bioerbicida, na $1^{\mathrm{a}}, 2^{\mathrm{a}}, 3^{\mathrm{a}}$ e $4^{\mathrm{a}}$ aplicação. Médias seguidas pela mesma letra na coluna não diferem significativamente entre si pelo teste de Tukey $(P<0,05)$.

Figura 54 - Teor de nitrogênio no solo após incorporação do bioerbicida, na $1^{\mathrm{a}}, 2^{\mathrm{a}}, 3^{\mathrm{a}}$ e $4^{\mathrm{a}}$ aplicação. Médias seguidas pela mesma letra na coluna não diferem significativamente entre si pelo teste de Tukey $(P<0,05)$.

Figura 55 - Acidez trocável do solo após incorporação do bioerbicida, na $1^{\mathrm{a}}, 2^{\mathrm{a}}, 3^{\mathrm{a}}$ e $4^{\mathrm{a}}$ aplicação. Médias seguidas pela mesma letra na coluna não diferem significativamente entre si pelo teste de Tukey $(P<0,05)$

Figura 56 - Teor de carbono orgânico no solo após incorporação do bioerbicida, na $1^{\mathrm{a}}, 2^{\mathrm{a}}, 3^{\mathrm{a}} \mathrm{e}$ $4^{\mathrm{a}}$ aplicação. Médias seguidas pela mesma letra na coluna não diferem significativamente entre si pelo teste de Tukey $(P<0,05)$.

Figura 57 - Estágio inicial de injúria na planta invasora Sida spinosa. 162

Figura 58 - Etapas da avaliação do bioerbicida na planta invasora Sida spinosa. (a) sem aplicação do bioerbicida; (b)16 dias após aplicação; (c) 30 dias após aplicação. As fotos b e c estão ampliadas para melhor visualização das injúrias..... 
Figura 59 - Planta invasora Sida spinosa 50 dias após aplicação do bioerbicida...................163

Figura 60 - Planta invasora Sida spinosa sem a ação do bioerbicida...................................164

Figura 61 - Desenvolvimento da planta invasora Sida spinosa .............................................166 


\section{LISTA DE TABELAS}

Tabela 1 - Propriedades físico-químicas dos compostos fenólicos selecionados no estudo....30

Tabela 2 - Experimento fatorial de dois fatores - caso geral..............................................55

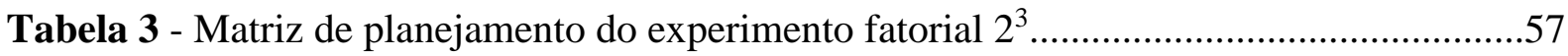

Tabela 4 - Produção mundial da soja (milhões de toneladas)................................................58

Tabela 5 - Consumo mundial da soja (milhões de toneladas) ................................................59

Tabela 6 - Metodologia de aplicação e avaliação dos efeitos visuais dos extratos contendo o potencial bioerbicida sobre as plantas invasoras, em intervalos iguais de 15

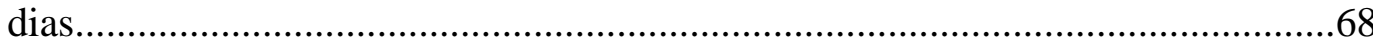

Tabela 7 - Programação utilizada para digestão de amostras de solo para análise de nitrogênio Kjeldahl (NKT) ............................................................................................

Tabela 8 - Programação da extração assistida via micro-ondas................................................77

Tabela 9 - Planejamento fatorial $2^{3-0}$, variável-resposta: Área..............................................79

Tabela 10 - Análise de variância (ANOVA) dos resultados experimentais.............................80

Tabela 11 - Estimativa dos efeitos (planejamento $2^{3-0}$, variável-resposta: Área): $R^{2}=0,999$;

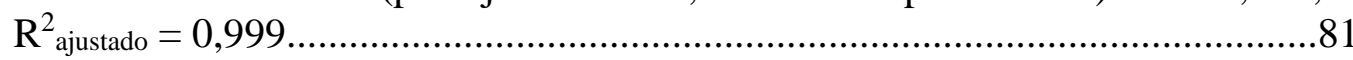

Tabela 12 - Experimentos ao longo do caminho de máxima inclinação..................................88

Tabela 13 - Experimentos ao longo do caminho de máxima inclinação $\left(\mathrm{t}=100^{\circ} \mathrm{C}\right) \ldots \ldots \ldots \ldots . . . . .88$

Tabela 14- Parâmetros otimizados do método de extração

Tabela 15 - Regressão linear, coeficiente de determinação, limite de detecção (LOD) e limite de quantificação (LOQ) dos compostos analisados

Tabela 16 - Recuperações médias $(\mathrm{n}=3)$ dos compostos ácido ferúlico, ácido clorogênico, rutina e naringenina em níveis de fortificação de 2,5 e $10 \mathrm{mg} \mathrm{L}^{-1}$ em extratos aquosos obtidos via extração assistida por micro-ondas das folhas da Canavalia ensiformis.

Tabela 17 - Descrição dos conceitos aplicados as avaliações de toxicidade segundo a SBCPD.

Tabela 18 - Escala utilizada para avaliação do controle da Emilia Sonchifolia após aplicação dos tratamentos (ALAM, 1974). 
Tabela 19 - Análise de variância (ANOVA) da altura e comprimento das folhas das plantas invasoras (Emilia sonchifolia) sob aplicação do bioerbicida e no vaso referência.....

Tabela 20 - Valores médios da porcentagem de controle da Emilia sonchifolia tratadas com 3,0 mL dos extratos aquosos da Canavalia ensiformis na concentração de $200 \mathrm{~g}$ $\mathrm{L}^{-1}$

Tabela 21 - Resultado das avaliações visuais dos tratamentos sobre a Emilia sonchifolia utilizando-se uma dose única de 3,0 mL do extrato contendo o bioerbicida, segundo a escala de conceitos da SBCPD.

Tabela 22 - Caracterização química do solo em estudo antes da implantação do experimento.

Tabela 23 - Caracterização física do solo utilizado.

Tabela 24 - Caracterização química inicial do solo e 15 dias após o início dos experimentos em casa de vegetação com a planta Emília sonchifolia.

Tabela 25 - Valores de pH do solo ao longo do experimento com planta Emília sonchifolia.

Tabela 26 - Teores de cálcio e potássio no solo ao longo do experimento com planta Emília sonchifolia.....

Tabela 27 - Teores de fósforo no solo ao longo do experimento com planta Emília sonchifolia.

Tabela 28 - Teores de nitrogênio no solo ao longo do experimento com planta Emília sonchifolia.

Tabela 29 - Teor de acidez trocável do solo ao longo do experimento com planta Emília sonchifolia.

Tabela 30 - Teor de capacidade de troca catiônica (CTC) do solo ao longo do experimento com planta Emília sonchifolia.....

Tabela 31 - Teores de carbono orgânico total no solo ao longo do experimento com a planta Emília sonchifolia.

Tabela 32 - Distribuição normal dos dados obtidos da caracterização do solo referente ao uso do bioerbicida na planta invasora Emilia sonchifolia.

Tabela 33 - Resultados da análise do solo após aplicação e incorporação do bioerbicida no solo, durante os experimentos com planta Emília sonchifolia.

Tabela 34 - Resultados da análise do solo referência e do solo analisado aos DAA75, durante os experimentos com planta Emília sonchifolia. 
Tabela 35 - Caracterização química inicial do solo e 15 dias após o início dos experimentos em casa de vegetação com a planta Sida spinosa.

Tabela 36 - Valores de $\mathrm{pH}$ do solo ao longo do experimento com a planta Sida spinosa.

Tabela 37 - Teores da capacidade de troca catiônica (CTC) do solo ao longo do experimento com a planta Sida spinosa.

Tabela 38 - Teores de cálcio e potássio no solo ao longo do experimento com a planta Sida spinosa......

Tabela 39 - Teor de fósforo disponível no solo ao longo do experimento com a planta Sida spinosa

Tabela 40 - Teor de nitrogênio no solo ao longo do experimento com a planta Sida spinosa.

Tabela 41 - Teor de acidez trocável e porcentagem de saturação por alumínio (m\%) no solo ao longo do experimento com a planta Sida spinosa.....

Tabela 42 - Interpretação dos valores de alumínio no solo (m\%). Segundo Osaki (1991).

Tabela 43 - Teores de carbono orgânico total do solo ao longo do experimento com a planta Sida spinosa.

Tabela 44 - Distribuição normal dos dados obtidos da análise do solo referente ao uso do bioerbicida na planta invasora Sida spinosa.

Tabela 45 - Resultados da análise do solo após aplicação e incorporação do bioerbicida no solo com a planta Sida spinosa..

Tabela 46 - Resultado das avaliações visuais dos tratamentos sobre a Sida spinosa 161

Tabela 47 - Análise de variância (ANOVA) da altura e comprimento das folhas da planta invasora (Sida spinosa) sob aplicação do bioerbicida e no vaso referência.......165

Tabela 48 - Valores médios da porcentagem de controle da Sida spinosa tratadas com 3,0 mL dos extratos aquosos da Canavalia ensiformis na concentração de $200 \mathrm{~g} \mathrm{~L}$ 1 


\section{LISTA DE ABREVIATURAS E SIGLAS}

ANOVA - Analysis of Variance

ABRASCO - Associação Brasileira de Saúde Coletiva

ANVISA - Agência Nacional de Vigilância Sanitária

ABNT- Associação Brasileira de Normas Técnicas

ALAM - Associación Latinoamericana de Malezas

CTC - Capacidade de Troca Catiônica

CLAE - Cromatografia Líquida de Alta Eficiência

CO - Carbono Orgânico

CV - Coeficiente de Variação

DAA - Dias Após Aplicação

DEAGRO - Departamento de Agronegócio

EMBRAPA - Empresa Brasileira de Pesquisa Agropecuária

EUA- Estados Unidos da América

FAPEMA - Fundação de Amparo à Pesquisa do Estado do Maranhão

FMAE - Focused Microwave-assisted Extraction

INMETRO- Instituto Nacional de Metrologia, Qualidade e Tecnologia

IBGE - Instituto Brasileiro de Geografia e Estatística

IQSC - Instituto de Química de São Carlos

LOD - Limite de detecção

LOQ - Limite de quantificação

LRQ- Laboratório de Resíduos Químicos

LQA - Laboratório de Química Ambiental

MAE - Microwave- assisted extraction

MAPA- Ministério de Agricultura, Pecuária e Abastecimento 
NKT - Nitrogênio Kjeldahl Total

$\mathrm{P}_{\text {disp }}$ - Fósforo disponível

PMAE - Pressurized Microwave-assisted Extraction

$\mathrm{Rpm}$ - rotações por minuto

SBCPD - Sociedade Brasileira de Ciência das Plantas Daninhas

SINDAG - Sindicato Nacional das Indústrias de Defensivos Agrícolas

TOC - Total Organic Carbon

TFSA - terra fina seca ao ar

UV-Vis - Ultravioleta Visível

USDA- United States Department of Agriculture

USP - Universidade de São Paulo 


\section{SUMÁRIO}

1 INTRODUÇÃO

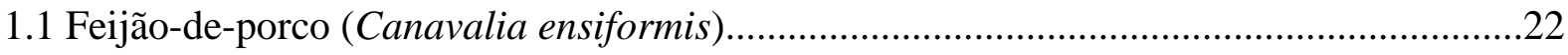

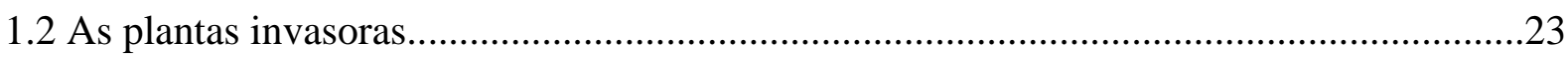

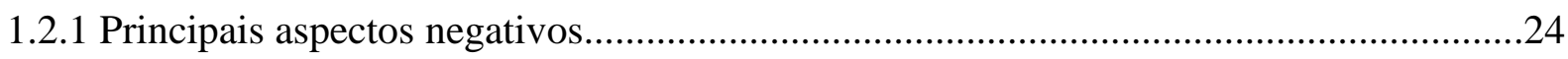

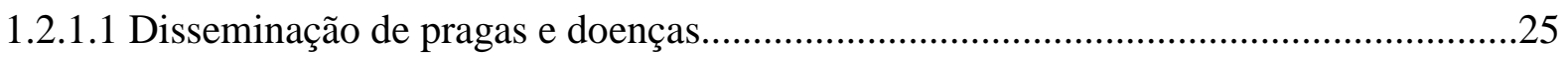

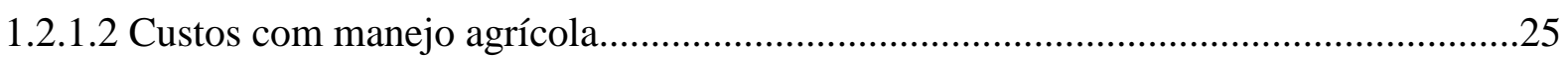

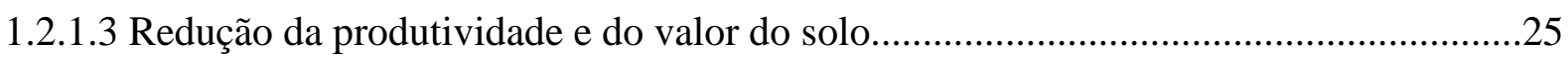

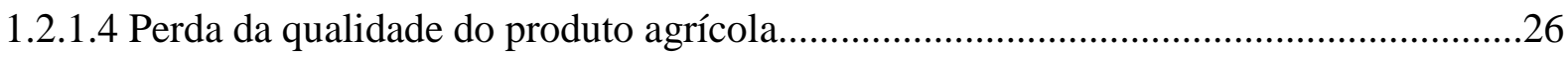

1.2.2 Plantas invasoras: guanxuma (Sida spinosa) e fala serralha (Emilia sonchifolia)...........26

1.3 Interação da cultura agrícola com as plantas invasoras................................................28

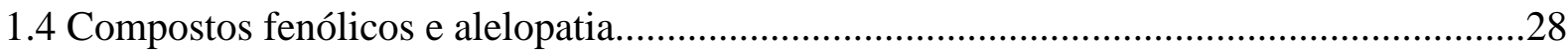

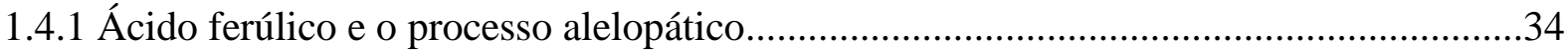

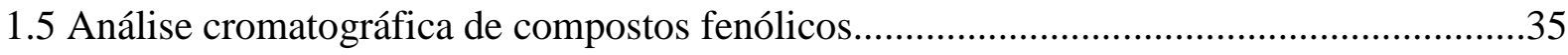

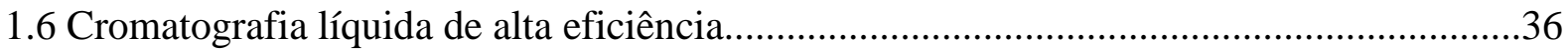

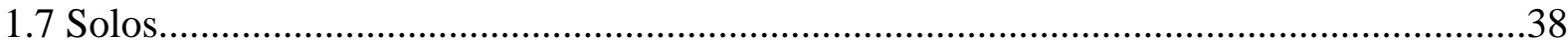

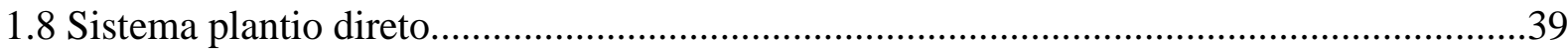

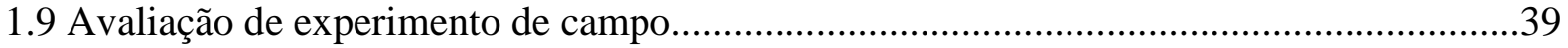

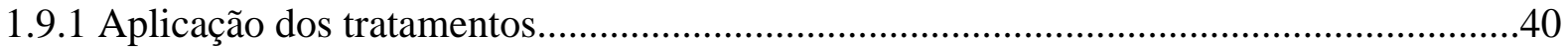

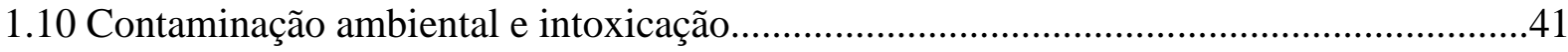

1.11 Problemática do uso de pesticidas na agricultura..........................................................42

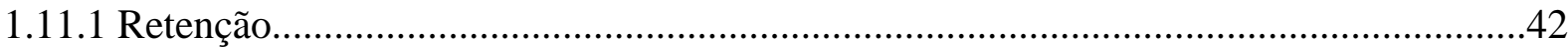

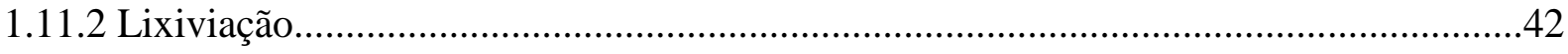

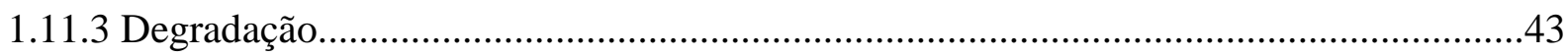

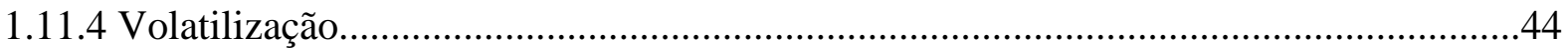




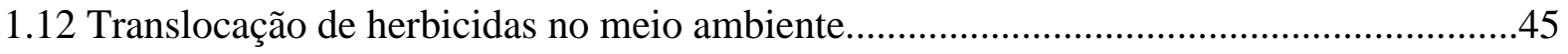

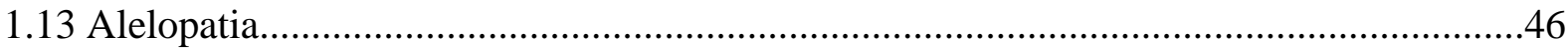

1.14 Apoptose

1.15 Extração de compostos fenólicos em plantas..............................................................49

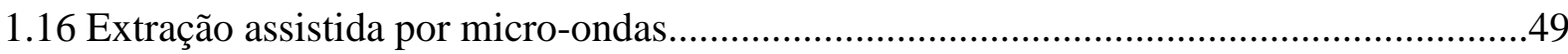

1.16.1 Extração de compostos fenólicos assistida por micro-ondas........................................50

1.16.2 Eficiência da extração-assistida por micro-ondas.........................................................51

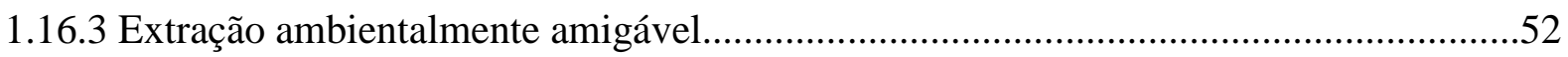

1.16.4 Extração assistida por micro-ondas: uso da água como solvente de extração...............53

1.17 Princípios básicos de planejamento e análise de experimentos.......................................53

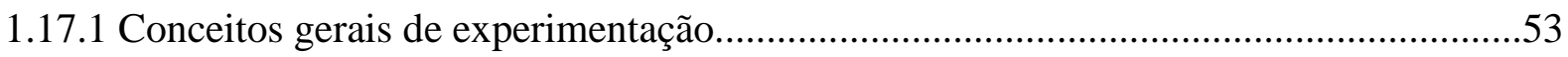

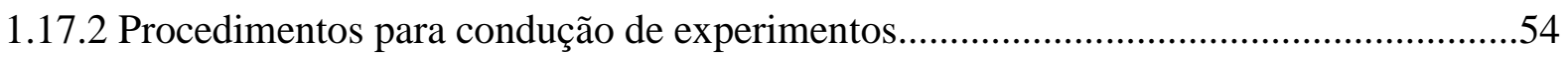

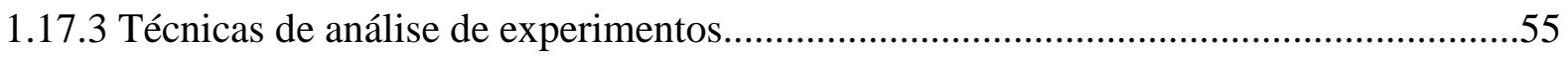

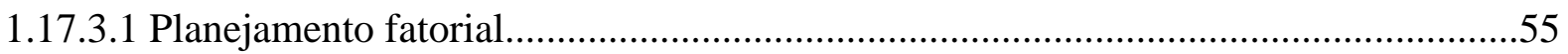

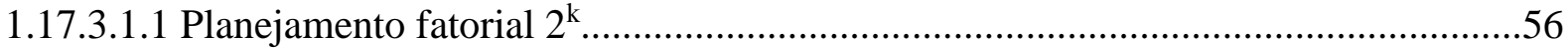

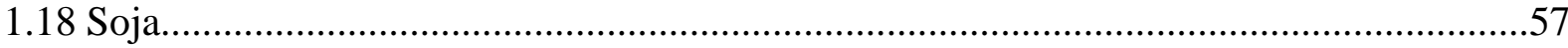

1.19 Sintomas da deficiência nutricional nas plantas.......................................................60

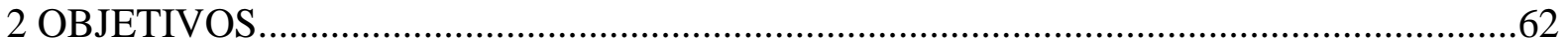

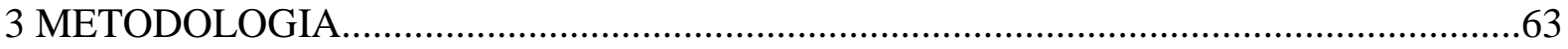

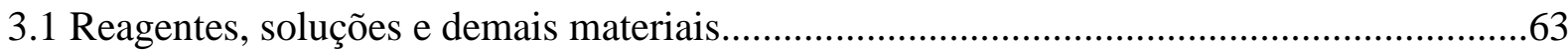

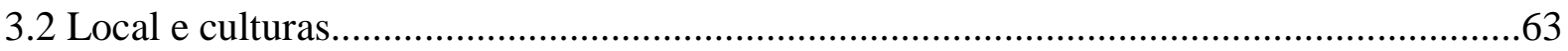

3.3 Extração dos compostos fenólicos das folhas do feijão-de-porco.....................................65

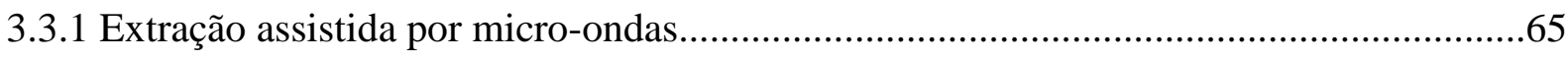

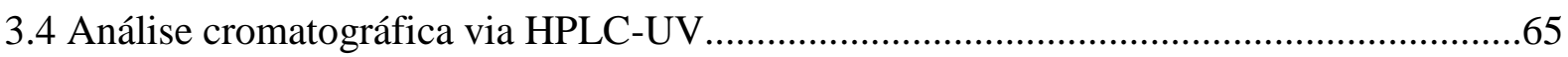

3.5 Extração assistida por micro-ondas: preparo dos extratos aquosos contendo os compostos

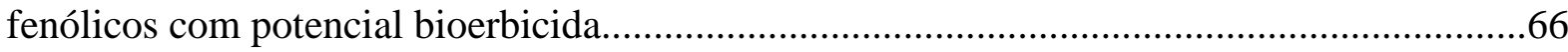


3.6 Ensaios em casa de vegetação: procedimento de aplicação dos extratos.

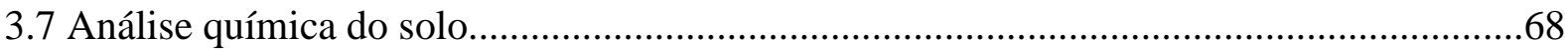

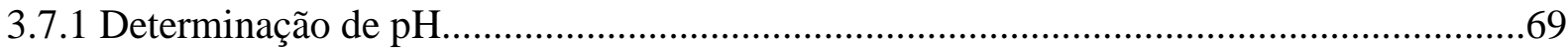

3.7.2 Determinação de cálcio e potássio................................................................................

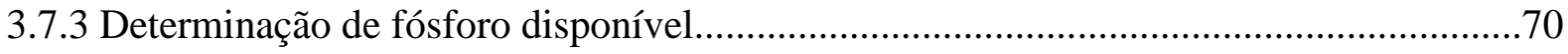

3.7.4 Determinação de nitrogênio (Nitrogênio Kjeldahl Total- NKT) ....................................70

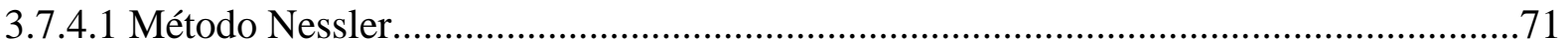

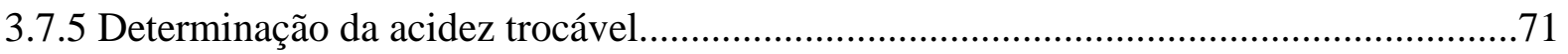

3.7.6 Determinação da capacidade de troca catiônica (CTC) ...............................................72

3.7.7 Determinação de carbono orgânico total (Total Organic Carbon- TOC)........................72

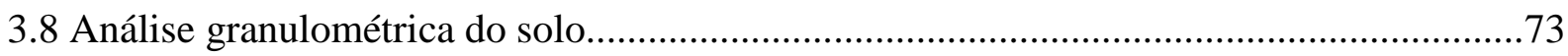

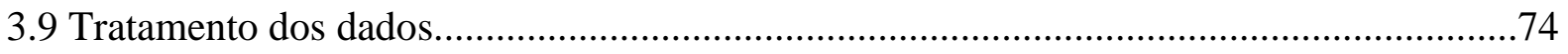

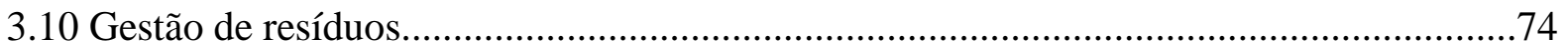

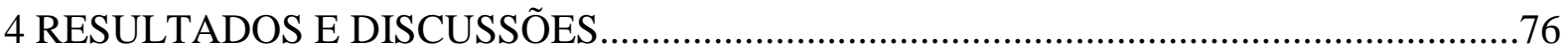

4.1 Extração assistida por micro-ondas: testes iniciais de extração.........................................76

4.1.1 Influência do tempo, potência e temperatura na extração.............................................76

4.1.2 Extração assistida por micro-ondas: otimização da metodologia....................................77

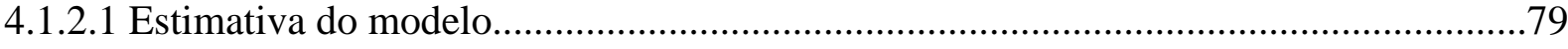

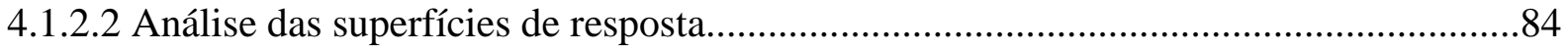

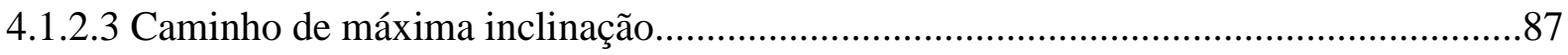

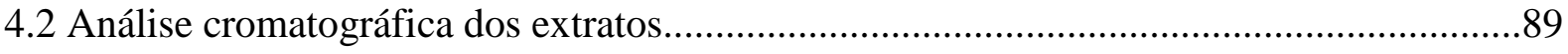

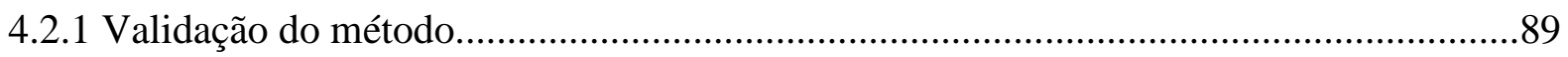

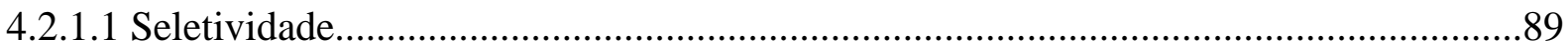

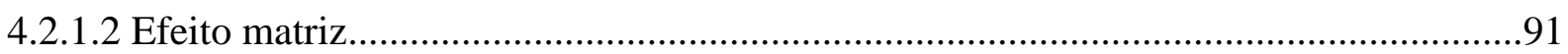

4.2.1.3 Linearidade (Curva de calibração) ........................................................................92

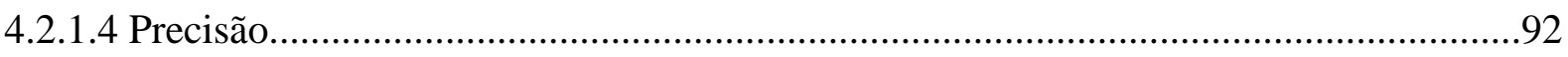

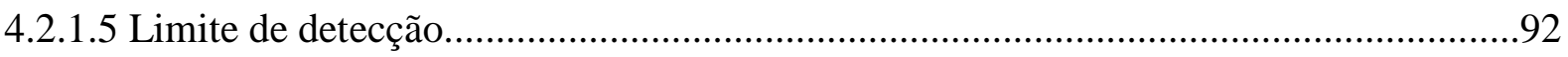


4.2.1.6 Limite de quantificação.

4.2.1.7 Ensaios de recuperação.

4.3 Testes inicias do potencial alelopático dos extratos aquosos contendo os compostos com atividade bioerbicida obtido via extração assistida por micro-ondas.

4.3.1 Definição do volume de extrato aquoso para aplicação foliar na planta invasora Emilia sonchifolia..... 105

4.3.2 Avaliação dos efeitos observados. 106

4.4 Caracterização química das amostras de solo sob cultivo da Emília sonchifolia.

4.5 Análise do solo após aplicação do bioerbicida

4.5.1 $\mathrm{pH}$

4.5.2 Cálcio e potássio.

4.5.3 Fósforo disponível.

4.5.4 Nitrogênio

4.5.5 Acidez trocável.

4.5.6 Capacidade de troca catiônica (CTC)

4.5.7 Carbono orgânico total.

4.6 Análise de variância dos dados (ANOVA).

4.7 Caracterização química da amostra de solo sob o cultivo da Sida spinosa.

4.7.1 Ensaios em casa de vegetação

4.8 Análise do solo após aplicação do bioerbicida

4.8.1 $\mathrm{pH}$.

4.8.2 Capacidade de troca catiônica (CTC).

4.8.3 Cálcio e potássio.

4.8.4 Fósforo disponível.

4.8.5 Nitrogênio.

4.8.6 Acidez trocável. 
4.9 Avaliação dos efeitos do bioerbicida no desenvolvimento da guanxuma (Sida spinosa)

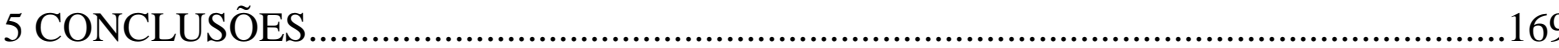

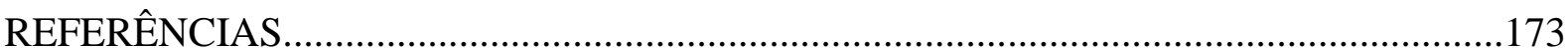

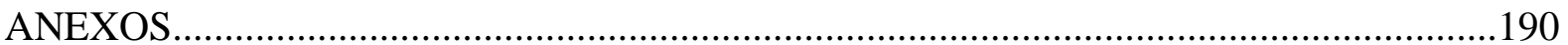




\section{INTRODUÇÃO}

Muito se discute acerca dos efeitos adversos causados pelo uso indiscriminado de pesticidas, em especial, de herbicidas; haja vista que estes são responsáveis por $45 \%$ do total do mercado mundial de pesticidas. Dessa forma buscam-se alternativas ambientalmente amigáveis de substituição de compostos tóxicos por outros menos tóxicos, tanto do ponto de vista ambiental, conforme já referido, quanto de saúde pública. Na tese ora apresentada visa-se à substituição de herbicidas sintéticos por extratos aquosos de folhas provenientes de feijão-deporco.

O feijão-de-porco (Canavalia ensiformis) é uma planta da família Fabaceae, amplamente cultivada nos países tropicais como cobertura verde, com raízes possuindo associação simbiótica com bactérias fixadoras de nitrogênio, dispensando a utilização de fertilizantes nitrogenados. Trata-se de uma planta rústica e muito adaptável aos solos de baixa fertilidade, pois imediatamente proporciona a melhora dos solos onde é cultivada. Neste trabalho foi avaliado seu caráter alelopático em plantações de soja. Por se tratar de um produto natural, de fácil cultivo, em que se utilizarão seus extratos aquosos, é de se supor que seu grau de toxicidade ao ambiente seja menor que o dos herbicidas comerciais. Vale testar a eficácia do processo no tocante à eliminação de plantas invasoras, ao não comprometimento da cultura de interesse (a soja) e avaliar todos os custos envolvidos. No entanto, tais estudos não contemplam os efeitos no solo. O que ocorrerá no solo com a utilização dos extratos aquosos de feijão-deporco após sucessivas aplicações? Quais as implicações no quesito fertilidade, nas mudanças na estrutura do solo? Estas e outras dúvidas serão avaliadas no desenvolvimento desta tese. Desta forma, espera-se contribuir com o estudo de utilização de extratos aquosos de feijão-deporco desde sua eficácia alelopática, determinação dos compostos envolvidos, efeitos na soja, custos e impacto no ambiente solo.

\subsection{Feijão-de-porco (Canavalia ensiformis)}

O controle de plantas invasoras por meio da utilização de herbicidas é uma prática de elevada importância para obtenção de altos rendimentos na exploração agrícola.

O feijão de porco é uma leguminosa de crescimento rápido usado como cobertura verde, como também cultura de consórcio; é conhecido por tolerar a acidez do solo e outras adversidades ambientais (Figura 1). Essa espécie é também microtrófica, sendo capaz de 
associar-se a fungos micorrízicos arbusculares (fungos benéficos ao solo) e com bactérias fixadoras de nitrogênio, sendo, portanto de interesse para áreas de revegetação de solos contaminados por elementos metálicos (ANDRADE et al., 2010).

Figura 1 - Sementes de feijão-de-porco (Canavalia ensiformis).

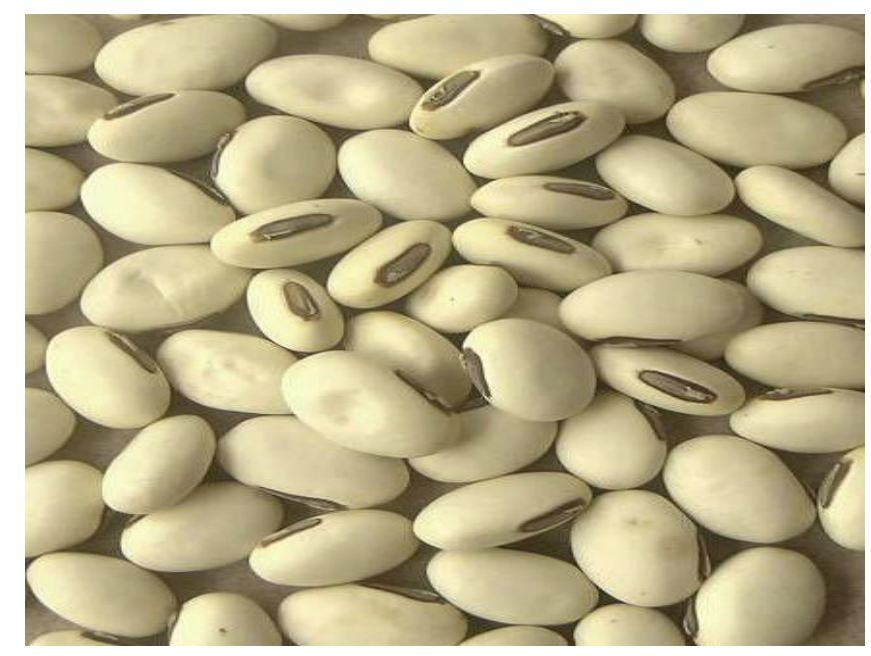

Fonte: Autoria própria.

O feijão de porco é uma espécie leguminosa que tem seu uso destinado à conservação de solos, devido a sua capacidade de fixação de nitrogênio e adaptação a solos de baixa fertilidade. O feijão de porco possui potencial fito-extrator de elementos metálicos tóxicos em solos contaminados (ALMEIDA et al., 2008). É uma planta originária da América do Sul e cresce nos trópicos e sub trópicos, produzida em grandes áreas especialmente em regiões de baixa altitude, altas temperaturas e alta umidade relativa (MOLINA, ARGUETA; BRESSANI, 1974).

Já é de conhecimento científico que o feijão-de-porco possui atividade alelopática, afetando o desenvolvimento de plantas invasoras de folha larga (MENDONÇA, 2008; MENDES, 2011).

\subsection{As plantas invasoras}

A ciência que estuda as plantas invasoras segundo alguns autores e a Sociedade Brasileira da Ciência das Plantas Daninhas é denominada de Ciência das Plantas Daninhas. Outros autores denominam como Herbologia, apesar do conceito ser inapropriado devido ao termo referir-se à erva e ao fato de que nem toda planta invasora apresenta hábito herbáceo. 
Há vários termos utilizados na literatura para descrever plantas invasoras, alguns destes considerados corretos ou não. Alguns desses termos podem ser utilizados, mas, dependendo da circunstância, pode estar errado ou mal empregado; outros termos são amplamente aceitos, mas nem sempre expressam a definição correta (CARVALHO, 2013).

É muito comum a descrição do termo erva daninha. Este termo, assim como comentado para o termo Herbologia, não está apropriado pois nem toda planta daninha é herbácea, embora a maioria seja. Algumas plantas daninhas são arbustivas ou arbóreas, ocorrendo, neste caso, o uso indevido do termo erva daninha (CARVALHO, 2013).

Planta infestante é outro termo utilizado, muitas vezes como sinônimo de planta daninha, em outras palavras, uma planta infestante, quando presente em um ambiente com atividade humana, provavelmente, será considerada uma planta daninha (Carvalho, 2013).

Planta espontânea é outro termo utilizado para definir planta daninha. Em geral, toda planta daninha é espontânea, mas nem toda planta espontânea será uma planta daninha. Por definição, planta espontânea é aquela que germina e emerge espontaneamente, mas não quer dizer que, com certeza, irá prejudicar uma atividade humana. A planta daninha, obrigatoriamente, prejudica atividade humana (CARVALHO, 2013).

Outro termo comum é planta invasora. Na verdade, uma planta invasora, pode ser uma planta daninha, desde que esteja invadindo uma área de interesse humano e que esteja causando algum tipo de transtorno. Porém, uma planta invasora presente em uma área de interesse humano não é considerada uma planta daninha, mesmo causando transtornos no ambiente (CARVALHO, 2013).

Neste sentido, o termo planta invasora será utilizado neste trabalho.

\subsubsection{Principais aspectos negativos}

As plantas invasoras apresentam tanto importância econômica quanto social, pois afetam atividade de produção, causando perdas econômicas com reflexos sociais. Em termos conceituais, as plantas invasoras causariam apenas impactos negativos sobre as atividades humanas (agricultura, pecuária, náutica, produção de energia, ...) porém, alguns autores consideram que há aspectos positivos de plantas invasoras para o ser humano como a utilização destas como medicamento e até como alimento (CARVALHO, 2013). 


\subsubsection{Disseminação de pragas e doenças}

As plantas invasoras são potenciais hospedeiras de pragas, doenças, nematoides, ácaros, bactérias e vírus, sendo portanto, fortes inócuos de micro-organismos em culturas de interesse econômico, como por exemplo da soja (CARVALHO, 2013).

As guanxumas (Sida spp.) são hospedeiras de pulgões (Aphis spp.) e da mosca-branca (Bemisia tabaci), vetores do mosaico-dourado em culturas de feijão, soja, algodão e outras. Outro problema potencial está relacionado aos nematoides. Muitas plantas invasoras hospedam nematoides, como os carurus (Amaranthus spp.), que hospedam o Pratylenchus brachiurus e Meloidogyne incognita, dentre vários outros (CARVALHO, 2013).

\subsubsection{Custos com manejo agrícola}

Uma lavoura com alta presença de plantas invasoras torna-se mais difícil de se manejar. Além disso, o custo de controle das plantas invasoras acarreta um aumento nos custos de produção. Em lavouras convencionais, o preparo do solo é mais intenso e há necessidade de adicionar outros cultivos. Em relação ao plantio direto, o uso de herbicidas geralmente é maior. A presença de plantas invasoras, por ocasião da colheita, pode trazer transtornos operacionais, retardando o processo de colheita e, consequentemente, aumentando as perdas e os custos de produção (CARVALHO, 2013).

\subsubsection{Redução da produtividade e do valor do solo}

A presença de plantas invasoras em áreas cultivadas reduz a produtividade da cultura de interesse. As perdas variam conforme a espécie e podem, inclusive, inviabilizar a colheita. Assim, dependendo da espécie e da densidade de indivíduos na área, o valor nutricional do solo pode ser reduzido (CARVALHO, 2013; VOLL et al., 2005).

Em áreas agrícolas, espécies tóxicas e de difícil controle como as guanxumas (Sida spp.), mio-mio (Baccaris coridifolia), maria-mole (Senecio brasiliensis) etc., também podem reduzir o valor do solo (CARVALHO, 2013). 


\subsubsection{Perda da qualidade do produto agrícola}

A presença de restos vegetas de plantas invasoras, por resultado de colheita, além das impurezas, pode resultar em aumento no teor de água do produto (leguminosas, grãos etc), que favorece o apodrecimento. Além disso, há a questão de contaminação entre lotes de sementes, como exemplo, do arroz (CARVALHO, 2013).

Como exemplo, em áreas de produção de algodão, a presença de plantas invasoras como o capim-carrapicho (Cenchrus echinatus) causam problemas na produção e no beneficiamento do algodão, depreciando a qualidade do produto (CARVALHO, 2013; LORENZI, 2002).

\subsubsection{Plantas invasoras: guanxuma (Sida spinosa) e falsa-serralha (Emilia sonchifolia)}

Sida spinosa (guanxuma) é um arbusto anual ereto, amplamente difundido ao longo das margens de rodovias, de rios e lagos. Um grande número de espécies do gênero Sida são usados em medicina tradicional para uma variedade de propósitos terapêuticos como adstringentes, contra problemas estomacais e nervosos, como também doenças cardíacas e urinárias (GUNATILAKA et al., 1980; LUTTERODT, 1988). Sida spinosa é usada no tratamento de asma e outros desconfortos no tórax como tônico (PRAKASH et al., 1981). Suas folhas, também são usadas para tratamento de algumas doenças de pele e como tratamento à mordida de cobra de acordo com os costumes populares no Egito (DARWISH; REINECKE, 2003).

Emilia sonchifolia (falsa-serralha, serralha vermelha, ...) é nativa das regiões quentes da

Ásia, África, Polinésia e Américas. É uma espécie amplamente disseminada em quase todo território brasileiro (YAMASHITA et al., 2009). É também uma planta medicinal encontrada em muitas regiões tropicais e subtropicais em todo mundo. Várias partes da planta são usadas para tratamento de doenças (LARA et al., 2003; MATOS et al., 1991; SINGH et al., 2013). Essa planta invasora é usada em etnomedicina (uso de plantas medicinais na cultura de um povo) contra inflamação, ferimentos nos olhos, convulsões, cortes, feridas, reumatismos e picadas de insetos (AGRA et al., 2007; SHYLESH et al., 2005). As figuras 2 e 3 mostram as plantas invasoras, guanxuma e falsa serralha, respectivamente. 
Figura 2 - Planta invasora guanxuma (Sida spinosa)

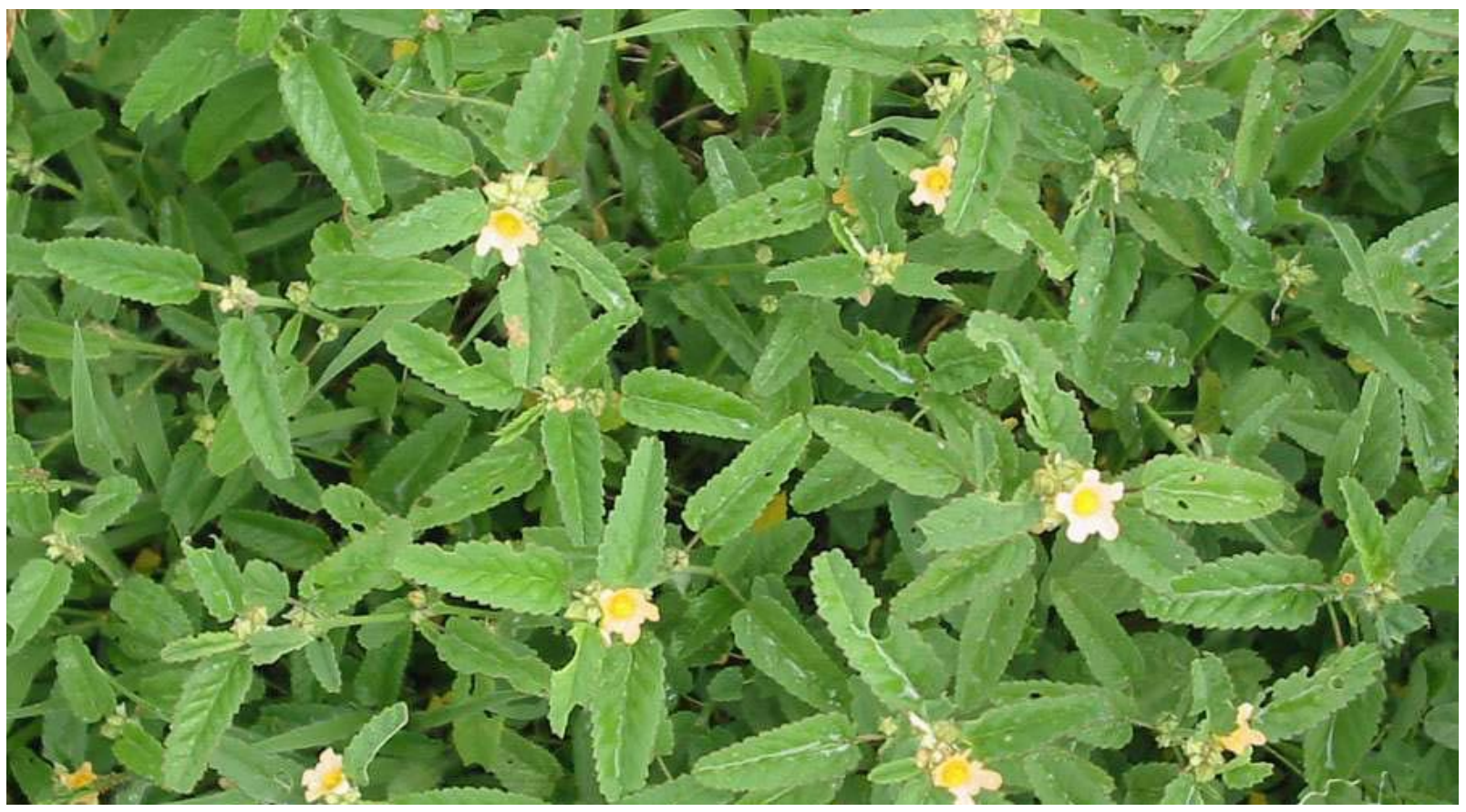

Fonte: Autoria própria.

Figura 3 - Planta invasora Falsa serralha (Emilia sonchifolia)

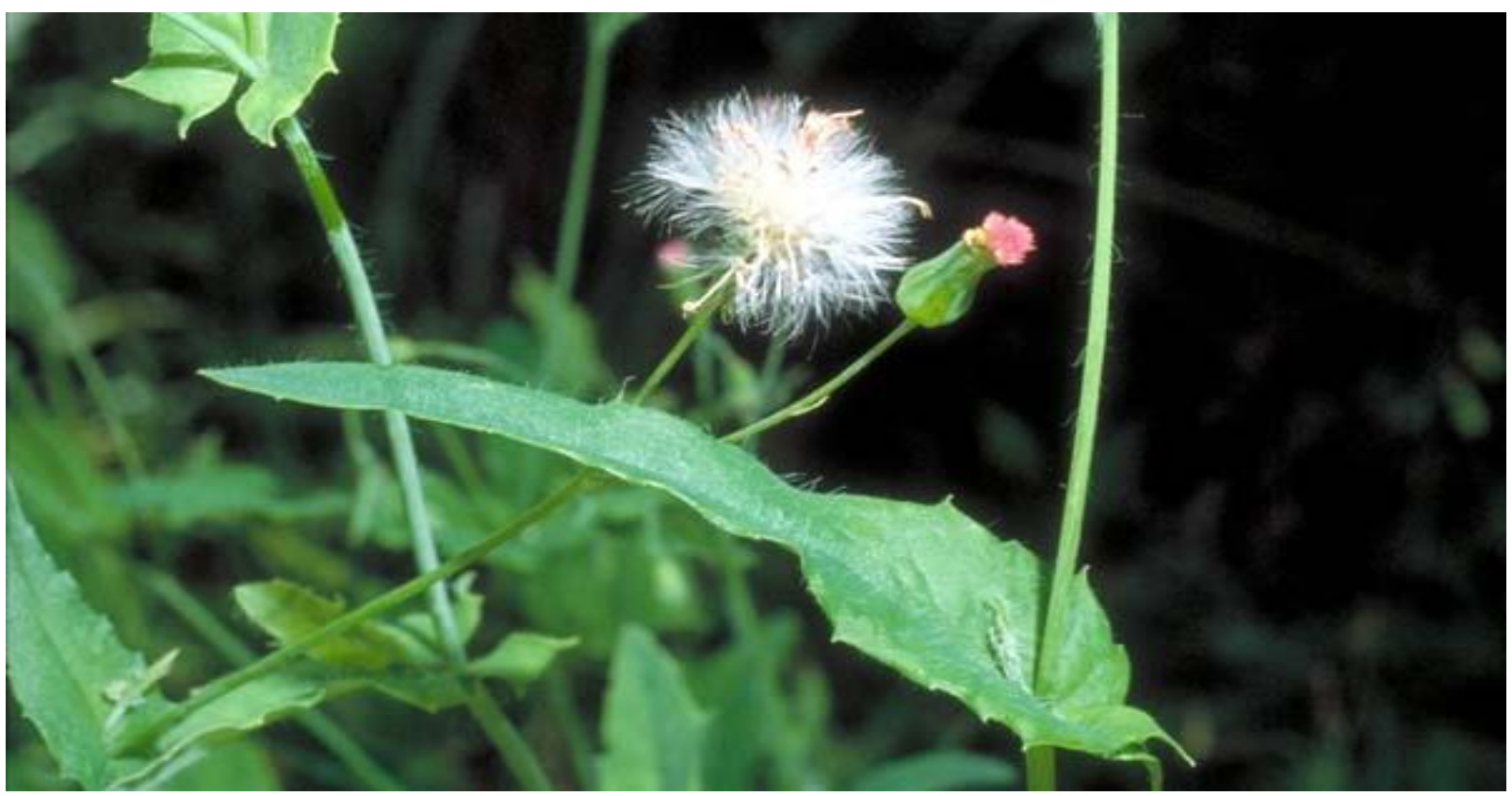

Fonte: Autoria própria. 


\subsection{Interação da cultura agrícola com as plantas invasoras}

De forma geral, a presença de plantas invasoras em culturas agrícolas causa um conjunto de ações negativas a determinado cultivo. Esse conjunto de ações negativas decorrem de pressões bióticas e abióticas que afetam o crescimento e o desenvolvimento de outras plantas. A competição é um exemplo de interação entre indivíduos da mesma espécie em que há prejuízo para ambos. Normalmente, a competição é descrita como uma interação planta-planta, onde há limitação de algum recurso ambiental exigido para o crescimento e desenvolvimento das plantas. Assim, a competição somente irá ocorrer quando pelo menos um recurso estiver limitado no meio. Caso o meio forneça o recurso (nutriente, água etc) em quantidade suficiente para atender a demanda de ambos os indivíduos, o simples fato de estarem convivendo no mesmo sistema não garante o estabelecimento de um tipo de competição (CARVALHO, 2013; LORENZI, 2002).

$\mathrm{Na}$ interação planta-planta, os principais recursos passiveis de competição são a água, nutrientes, luz e espaço, podendo haver, ainda, limitação de gases como o $\mathrm{CO}_{2}$ e $\mathrm{O}_{2}$. É importante ressaltar que a ocupação do espaço (limitação do espaço), está diretamente relacionada à competição por água, nutrientes e luz, ou seja, quando a planta ocupa mais espaço está consequentemente alocando mais recursos do meio (CARVALHO, 2013).

$\mathrm{Na}$ competição, determinada planta aloca recurso do meio e impossibilita que outra planta possa também fazer uso desse recurso. Nesse caso, o principal efeito é a redução na quantidade de produto produzido (produtividade) (CARVALHO, 2013).

A competição é a principal causa de redução de produtividade em cultivos agrícolas, pois as plantas invasoras requerem, para o seu desenvolvimento, os mesmos recursos que as plantas cultivadas (CARVALHO, 2013).

\subsection{Compostos fenólicos e alelopatia}

A maior consideração quando se utilizam pesticidas (herbicidas, inseticidas etc) é a sensibilidade e perigo a outras espécies não-alvo e organismos na área de aplicação (CALLIHAN et al., 1995). Segundo o Ministério de Agricultura, Pecuária e Abastecimento (MAPA), os pesticidas são produtos químicos ou biológicos, destinados ao uso nos setores de produção, armazenamento e beneficiamento de produtos agrícolas, pastagens, urbanos, hídricos e industriais (MAPA, 2016). 
Aplicações inadequadas podem causar muitos danos a outras espécies, consequentemente, afetando a qualidade das águas, causando o acúmulo desses compostos no subsolo e nos corpos d'água (CALLIHAN et al., 1995).

Compostos fenólicos são metabólitos secundários que podem ser comumente encontrados em muitas plantas (Bernal et al., 2010). Esses compostos merecem considerável atenção devido às suas atividades antioxidantes, fortemente relacionadas à prevenção de câncer, desordens inflamatórias e doenças cardiovasculares (CICERALE; LUCAS; KEAST, 2010; OMAR, 2010; SERVILI et al., 2009).

Os compostos fenólicos derivados de plantas recebem considerável interesse devido a seu potencial antioxidante e suas propriedades antimicrobianas. Muitas plantas são consideradas excelentes fontes destes compostos, que podem ser usados, não apenas para preservar a planta como também contribuir com uma dieta saudável (JUSTESEN; KNUTHSEN, 2001; RICE-EVANS, MILLER; PAGANGA, 1997). Dentre tais compostos incluem-se, principalmente, os fenóis, ácidos fenólicos, cumarinas, taninas e flavonoides. Esses compostos são encontrados normalmente na forma de glicosídeos ou ésteres, principal razão da tendência de serem altamente solúveis em água (HARBORNE, 1998).

Os metabólitos secundários presentes nas plantas podem afetar diversos processos no ecossistema. A liberação de metabólitos secundários no ambiente desencadeia diversas interações bióticas, como a decomposição das folhas das plantas, exsudatos radiculares, vaporização para o ar e lixiviação de partes das plantas para o solo. Entretanto, a persistência, disponibilidade e atividade biológica dos aleloquímicos são influenciados pelos microorganismos presentes no solo. A degradação de aleloquímicos pelos micro-organismos do solo determinam a força da alelopatia em muitas situações (ZHOU; WU, 2012).

Nos últimos anos o interesse por compostos naturais tem aumentado, especificamente, por alguns compostos com propriedades alelopáticas, incluindo os ácidos fenólicos e flavonoides que são conhecidos por inibir várias bactérias e fungos (RAUHA et al., 2000; ERASTO et al., 2004; TEPE et al., 2004).

Assim, certas plantas produzem compostos fenólicos com potencial alelopático que podem ser utilizados como herbicidas naturais, denominados bioerbicida em trabalhos anteriores do grupo de pesquisa (SANTOS, 2004; MENDONÇA, 2008; MENDES, 2011; MENDES; REZENDE, 2014). Essa ideia é baseada em três observações experimentais: 1. Ação alelopática contra várias plantas; 2. A sua solubilidade em água, o que facilita sua utilização como composto fitossanitário e 3. Sua biodegradabilidade por micro-organismos, que impedem 
o acúmulo desses compostos no solo (TIGRE et al., 2015). A Figura 4 mostra as estruturas moleculares dos compostos fenólicos estudados neste trabalho.

Figura 4 - Estruturas moleculares dos compostos fenólicos selecionados.<smiles>O=C(/C=C/c1cccc(O)c1O)O[C@H]1C[C@@](O)(C(=O)O)C[C@H](O)[C@H]1O</smiles>

Ácido clorogênico<smiles>O=C1C[C@H](c2ccc(O)cc2)Oc2cc(O)cc(O)c21</smiles>

Naringenina<smiles></smiles>

Rutina<smiles>COc1cc(/C=C/C(=O)O)ccc1O</smiles>

Ácido ferúlico

Na Tabela 1, são apresentadas algumas características físico-químicas dos compostos fenólicos estudados.

Tabela 1 - Propriedades físico-químicas dos compostos fenólicos selecionados no estudo.

\begin{tabular}{|c|c|c|c|c|}
\hline Compostos & $\begin{array}{c}\text { Massa } \\
\operatorname{molar}(\mathrm{g} \\
\left.\mathrm{mol}^{-1}\right)\end{array}$ & Nome químico & $\begin{array}{l}\text { Fórmula } \\
\text { molecular }\end{array}$ & $\begin{array}{l}\text { Ponto de } \\
\text { fusão }\left({ }^{\circ} \mathrm{C}\right)\end{array}$ \\
\hline Ácido clorogênico & 354,31 & Ácido 5-cafeoilquínico & $\mathrm{C}_{16} \mathrm{H}_{18} \mathrm{O}_{9}$ & 210 \\
\hline Rutina & 610,52 & $\begin{array}{l}\text { Quercetina rutinoside-3- } \\
\text { hidrato }\end{array}$ & $\mathrm{C}_{27} \mathrm{H}_{30} \mathrm{O}_{16}$ & 195 \\
\hline Naringenina & 272,25 & $\begin{array}{l}\text { Naringenina } 4 ', 5,7- \\
\text { trihidroxiflavanona }\end{array}$ & $\mathrm{C}_{15} \mathrm{H}_{12} \mathrm{O}_{5}$ & $247-250$ \\
\hline Ácido ferúlico & 194,18 & $\begin{array}{l}\text { Ácido trans-4-hidroxi-3- } \\
\text { metoxicinâmico }\end{array}$ & $\mathrm{C}_{10} \mathrm{H}_{10} \mathrm{O}_{4}$ & $168-172$ \\
\hline
\end{tabular}


O processo de alelopatia causa um efeito prejudicial ou benéfico entre plantas por meio de substâncias químicas que são lançadas no meio, os chamados aleloquímicos. Essas substâncias podem interferir na germinação e no desenvolvimento de espécies vegetais próximas (FERREIRA et al., 2010).

Ácidos fenólicos são excretados tanto pelas raízes como pelos micro-organismos presentes na planta, são de interesse em horticultura, principalmente em sistemas de cultivo que não utilizam o solo (hidroponia), pois tais compostos acumulam-se nas raízes tendo atividade fitotóxica e alelopática como forma de proteção da própria planta (Jung et al., 2004). Possuem capacidade antioxidante assim como os flavonoides, isoflavonas, flavonas, antocianonas, catequins e demais grupos fenólicos (SHAH; HOSSAIN, 2014).

Os ácidos fenólicos são compostos simples, formados por um único anel aromático com substituintes ligados à sua estrutura que lhe conferem a capacidade de sequestrar espécies reativas, como o radical hidroxila e o oxigênio. São divididos em dois grupos: ácidos hidroxibenzóicos, os quais possuem sete átomos de carbono (C6-C1) e são ácidos fenólicos mais simples, facilmente encontrados na natureza, dentre eles os ácidos: gálico, $p$ hidroxibenzóico, protocatecuico, vanílico e siríngico. O segundo grupo é formado pelos ácidos hidroxicinâmicos, que possuem nove átomos de carbono (C6-C3), sendo os mais comumente encontrados na natureza, os ácidos caféico, ferúlico, $p$-cumárico e sinápico. Os ácidos fenólicos, além de se apresentarem sob sua forma livre, podem também estar ligados entre si ou a outros compostos (ROCKENBACH, 2008).

A atividade antioxidante dos ácidos fenólicos depende do número e posição de grupos hidroxila em relação ao grupo funcional carboxila. Os ácidos monohidroxibenzóicos com o grupo $\mathrm{OH}$ ligado nas posições orto ou para em relação ao grupo $\mathrm{COOH}$ não apresentam atividade antioxidante, porém, o mesmo não acontece com o ácido $m$-hidroxibenzóico. A atividade antioxidante dos ácidos fenólicos aumenta à medida que aumenta o grau de hidroxilação, como no caso do ácido gálico (trihidroxilado), que apresenta alta atividade antioxidante. Em contrapartida, a substituição em outras posições por grupos metoxila, como no caso do ácido siríngico, reduz a atividade antioxidante (ROCKENBACH, 2008). As figuras 5 e 6 mostram os principais ácidos hidroxibenzóicos e hidrocinâmicos, respectivamente. 
Figura 5 - Estrutura molecular dos ácidos hidroxibenzóicos.<smiles>O=C(O)c1cc(O)c(O)c(O)c1</smiles>

Ácido gálico<smiles>COc1cc(C(=O)O)cc(OC)c1O</smiles>

Ácido siríngico<smiles>O=C(O)c1ccc(O)c(O)c1</smiles>

Ácido protocatecuico<smiles>O=C(O)c1cccc(O)c1</smiles>

Ácido p-hidroxibenzóico

Figura 6 - Estrutura molecular dos ácidos hidroxicinâmicos.<smiles>O=C(O)/C=C/c1cccc(O)c1</smiles>

Ácido p-cumárico<smiles>COc1cc(/C=C/C(=O)O)ccc1O</smiles>

Ácido ferúlico<smiles>O=C(O)/C=C/c1ccc(O)c(O)c1</smiles>

Ácido caféico<smiles>COc1cc(/C=C/C(=O)O)cc(CO)c1O</smiles>

Ácido sinápico

Os flavonoides, além de antioxidantes, fazem parte da pigmentação das plantas ao longo dos seus estágios de desenvolvimento e participam da proteção da membrana lipídica da oxidação (SHAHIDI; WANASUNDARA, 1992; SHAH; HOSSAIN, 2014).

Os flavonoides constituem o maior grupo de compostos fenólicos de plantas. Ocorrem naturalmente em alimentos de origem vegetal e são comuns em dietas do mundo inteiro, são responsáveis pela coloração das flores e dos frutos (ROCKENBACH, 2008).

São compostos de baixa massa molar, consistindo de 15 átomos de carbono arranjados em uma configuração C6-C3-C5. Sua estrutura é formada por dois anéis aromáticos A e B 
ligados por uma ponte de três carbonos, usualmente na forma de anel heterocíclico (Figura 7). O anel aromático A é derivado da via metabólica do acetato/malonato, enquanto que o anel B é derivado da fenilalanina através da via metabólica do chiquimato. Variações nas configurações de substituição do anel $\mathrm{C}$ resultam na maioria das subclasses dos flavonoides: flavonas, isoflavonas, flavononas, flavonois e antocianinas (Figura 8) (ROCKENBACH, 2008).

Figura 7 - Estrutura genérica das moléculas dos flavonoides.

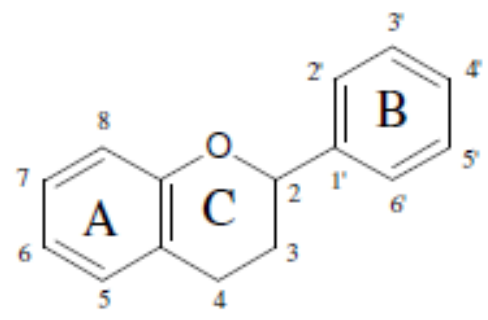

Figura 8 - Estrutura genérica das principais classes dos flavonoides.<smiles></smiles>

Antocianina<smiles>O=c1c(O)c(-c2ccccc2)oc2ccccc12</smiles>

Flavanona<smiles>O=C1CC(c2ccccc2)Oc2ccccc21</smiles>

Flavona<smiles>OC1Cc2ccccc2OC1c1ccccc1</smiles>

Flavanol<smiles>O=c1c(O)c(-c2ccccc2)oc2ccccc12</smiles>

Flavonol

Fonte: Rockenbach, 2008 
Dos principiais flavonoides, as antocianinas, são efetivos doadores de hidrogênio. Seu potencial antioxidante depende do número e da posição dos grupos de hidrogênio e suas conjugações e também devido à presença de elétrons nos anéis benzênicos. A atividade dos flavonoides é geralmente mais complexa que a dos ácidos fenólicos devido às suas moléculas. A presença de grupos hidroxila nas posições 3, 4 e 5 no anel aromático B (Figura 7) são responsáveis pelo aumento da atividade antioxidante, como exemplo, a conversão do composto 3,4-dihidroxifenil para 3,4,5-trihidroxifenil aumenta a atividade antioxidante. Entretanto, a substituição de grupos hidroxila no anel B por grupos metoxila diminui o potencial antioxidante dos flavonoides. (ROCKENBACH, 2008).

\subsection{1 Ácido ferúlico e o processo alelopático}

Uma das estratégias mais comuns de pré e pós colheita é baseada na aplicação de herbicidas e fungicidas. Entretanto, muito destes compostos sintéticos oferecem risco à saúde humana e ao próprio ambiente. Assim, cresce a busca por compostos naturais que reduzam o impacto toxicológico. O ácido ferúlico é seguro para a saúde humana, possui propriedades terapêuticas como a anti-inflamatória, anti-aterogênica (relacionado aos índices de colesterol), anti-diabética, neuroprotetora, radioprotetora e hepatoprotetora (FERROCHIO et al., 2013).

O ácido ferúlico é um dos ácidos fenólicos mais abundantes nas plantas e pode ser encontrado em altas concentrações em alimentos tais como no feijão branco, no farelo de milho, no farelo de aveia, berinjela, alcachofra e beterraba (RECHNER et al., 2001). Pode ser encontrado livre, dimerizado ou esterificado com proteínas e polissacarídeos na parede celular, tal como o arabinoxilano em gramas e os xiloglucanos em bambu (RUMBOLD et al., 2003). O ácido ferúlico é um componente biológico e estrutural importante da parede celular. Devido à sua habilidade de parar as reações em cadeia através de ressonância e polimerização, o ácido ferúlico oferece proteção contra radiação UV e é responsável pela reticulação (interligação de cadeias poliméricas) dos polissacarídeos e outros polímeros na parede celular (SANTOS et al., 2008).

O ácido ferúlico [ácido 2-propenoico, 3-(4-hidroxi-3-metoxifenil)] é um composto fenólico fitoquímico presente em diversas sementes e folhas, sendo em ambas na forma livre e covalentemente conjugada na parede celular por polissacarídeos, glicoproteínas, poliaminas, lignina e ácidos graxos. Pode ser encontrado como um monômero, dímero, como oligômero ou na forma de polímero, covalentemente ligado por ligações de éster com polissacarídeos, poliaminas, bem como éter ligado a lignina. Possui dois isômeros: o cis (líquido amarelo oleoso) 
e trans (cristal branco), sendo este último correspondente a $90 \%$ da ocorrência natural (PAIVA et al., 2013).

O ácido ferúlico é um precursor da formação da lignina e é de vital importância pois providencia a rigidez da parede celular e a formação de outros importantes compostos orgânicos (LOCHER et al., 1994). O ácido ferúlico e outros ácidos fenólicos são lançados pelas raízes e pelos resíduos da decomposição das plantas (SIQUEIRA et al., 1991; WU et al., 2010). Devido à sua toxicidade para as plantas, o ácido ferúlico é considerado um agente alelopático, têm correlação positiva entre a área das folhas e a massa seca quando aplicado (CASPERSEN et al., 2000).

Baixas concentrações de ácidos fenólicos nas raízes podem estimular o crescimento, efeitos fitotóxicos ocorrem frequentemente em altas concentrações (RICE, 1984; SIQUEIRA et al., 1991; CASPERSEN et al., 2000).

Os micro-organismos são capazes de metabolizar e produzir uma faixa de compostos fenólicos no sistema solo-planta (SIQUEIRA et al., 1991). Outra ideia é a de que as plantas podem ser protegidas contra compostos potencialmente tóxicos no solo pela capacidade de desintoxicação metabólica da comunidade microbiana da rizosfera (WALTON et al., 1994). O aumento da degradação de xenobióticos que é frequentemente observada na rizosfera do solo pode ser associada com a entrada de compostos de carbono pelas raízes das plantas (SHANN; BOYLE, 1994). A rápida decomposição do ácido ferúlico geralmente impede a sua acumulação no solo (TURNER; RICE, 1975), e tratamento do solo com ácido ferúlico pode resultar na indução ou seleção de micro-organismos que podem utilizar o ácido ferúlico como fonte de carbono (SPARLING et al., 1981; SHAFER; BLUM, 1988).

\subsection{Análise cromatográfica de compostos fenólicos}

Existem muitos métodos de separação de compostos fenólicos, tais como a cromatografia líquida de alta eficiência (ASKUN et al., 2009; CHEN, ZUO; DENG, 2001), cromatografia gasosa (ZUO, WANG; ZHAN, 2002) e eletroforese capilar (GANZERA et al., 2008; SANTOS et al., 2005; SANTOS et al., 2005; SANTOS, MORAES; REZENDE, 2007).

Tradicionalmente, os procedimentos de extração de compostos fenólicos em extratos de plantas são baseados em extração líquido-líquido (ELL). Entretanto, ELL implica no uso de grande volume de solventes orgânicos, além de muito consumo de tempo. Em relação à análise quantitativa, vários métodos podem ser utilizados, tais como: espectroscopia UV, cromatografia gasosa, eletroforese capilar e cromatografia capilar eletrocinética micelar. Entretanto alguns 
desses métodos possuem limitações e uma alternativa para superar esses problemas é a cromatografia líquida de alta eficiência acoplada a vários detectores tais como: ultravioleta (UV), arranjo de diodos (DAD), espectrometria de massas (MS) (ARTURKI et al., 2008).

De todos estes, MS/MS surgiu como uma das técnicas analíticas preferenciais para quantificação, proporcionando sensibilidade adequada como também clareza na identificação e quantificação de compostos fenólicos em níveis traço em uma única injeção. A cromatografia gasosa requer geralmente muito tempo no processo de derivatização e operação em altas temperaturas, o que pode conduzir à decomposição das amostras (CHINNICI et al., 2005).

Há algumas metodologias descritas para análise de compostos fenólicos por cromatografia gasosa, baseadas nas suas características de polaridade. Os ácidos fenólicos são compostos que possuem alta polaridade e baixa pressão de vapor. Assim, o procedimento de análise desses compostos requer um arranjo nas condições cromatográficas de análise, como forma de melhor isolar e caracterizar tais compostos (ROCKENBACH, 2008).

A cromatografia gasosa (CG) e a cromatografia líquida de alta eficiência (CLAE) são técnicas usadas tanto na separação quanto na quantificação de compostos fenólicos. Quando combinadas, juntamente com a espectrometria de massas, são utilizadas para a elucidação de estruturas (ROCKENBACH, 2008).

Determinações quantitativas de compostos fenólicos em extratos e/ou óleos essenciais são comumente feitas por métodos colorimétricos, entretanto esses métodos não são específicos, pois não indicam a natureza dos compostos fenólicos presentes. Separação e identificação de compostos individuais têm sido feitas por cromatografia gás-líquido e detecção seletiva de massas (PROESTOS, SERELI; KOMAITIS, 2006).

Em geral, as separações de ácidos fenólicos e flavonoides são feitas por cromatografia líquida de alta eficiência, utilizando colunas de fase reversa, geralmente empacotadas com partículas esféricas de sílica ligada com cadeias de octadecil (C18) (MOLNÁR-PERL e FÜZFAI, 2005; RIJKE et al., 2006).

\subsection{Cromatografia líquida de alta eficiência}

A cromatografia líquida de alta eficiência é um importante membro de toda uma família de técnicas de separação, uma vez que consegue separar misturas que contêm um grande número de compostos similares. Atualmente, seu emprego em vários laboratórios é indispensável. Conhecer suas vantagens, limitações, componentes e os critérios de escolha entre as opções de equipamentos e acessórios disponíveis é uma obrigação dos profissionais de 
laboratórios químicos, farmacêuticos, bioquímicos entre outros (COLLINS, BRAGA; BONATO, 2011).

Vários nomes têm sido utilizados para denominar esta técnica de cromatografia líquida: alta velocidade, alta pressão, alto desempenho, alta resolução e alta eficiência. O nome mais empregado em português seria "cromatografia líquida de alta eficiência" (CLAE) (COLLINS, BRAGA; BONATO, 2011).

A CLAE utiliza instrumentos que podem ser completamente automatizados. É um tipo de cromatografia que utiliza colunas recheadas com materiais especialmente preparados e uma fase móvel, eluída sob altas pressões. Esta técnica também é capaz de fazer separações e análises quantitativas de uma grande variedade de compostos presentes em diversos tipos de amostras, em escala de tempo de poucos minutos, com alta resolução, eficiência e detectabilidade (COLLINS, BRAGA; BONATO, 2011).

$\mathrm{Na}$ CLAE emprega-se uma coluna fechada, reaproveitável; portanto, até centenas de separações individuais podem ser feitas com a mesma coluna. Podem-se utilizar colunas mais eficientes que oferecem grande resistência à vazão da fase móvel, utilizando bombas de alta pressão. O uso de bombas de alta pressão faz com que a fase móvel migre a uma velocidade razoável através da coluna, resultando em operações mais reprodutíveis tornando as análises mais precisas (COLLINS, BRAGA; BONATO, 2011).

A CLAE requer que a amostra seja solúvel na fase móvel. Assim, é o método ideal para a separação de espécies iônicas ou macromoléculas de interesse biológico e produtos naturais lábeis, assim como de diversos outros compostos de massa molecular alta e/ou estabilidade térmica baixa (COLLINS, BRAGA; BONATO, 2011).

O detector UV-Vis baseia-se no princípio da absorção da luz pela amostra através da radiação eletromagnética (ultravioleta/visível) (COLLINS; BRAGA, 1987). Existem três tipos de detectores UV-Vis: o detector de comprimento de onda fixo, variável e por arranjo de diodos. O detector de comprimento de onda fixo utiliza apenas um comprimento de onda, limitando a análise a compostos que absorvam apenas em um comprimento de onda. Já no detector de comprimento variável é possível ajustar mais de um comprimento de onda de forma que a análise torna-se mais versátil. Os detectores de UV-Vis podem emitir luz ultravioleta por lâmpada de deutério assim como na região do visível utilizando lâmpadas de tungstênio, em uma faixa de 190-800 $\mathrm{nm}$. Os detectores por arranjo de diodos fornecem espectros na região do UV-Vis do eluente da coluna em determinados intervalos de tempos. São de especial importância pois possibilitam a varredura da região UV-Vis em uma única corrida 
cromatográfica, em métodos de análises de amostras desconhecidas (SKOOG, HOLLER; NIEMAN, 2006).

\subsection{Solos}

Segundo a Embrapa, o solo é uma coleção de corpos naturais, constituídos por partes sólidas, líquidas e gasosas, em estruturas tridimensionais, dinâmicas, formadas por materiais minerais e orgânicos que constituem a maior parte do manto superficial das extensões continentais do nosso planeta, contém matéria viva e podem ser vegetados na natureza onde ocorrem e, eventualmente, modificados por interferências antrópicas (EMBRAPA, 2006).

No território brasileiro e em grande parte na América Latina são predominantes os solos altamente intemperizados, ou seja, vem de um processo de transformação ou degradação de rochas; que têm como exemplo, os Latossolos e os Argissolos. Esses ocupam extensas áreas de cultura e são importantes como reservas naturais. Pela sua formação e por influência de sua mineralogia, esses solos apresentam propriedades agronomicamente desejáveis, como boa profundidade, boa porosidade e alta permeabilidade, entretanto, podem ser tóxicos pelo alumínio, com baixa reserva de nutrientes, baixa capacidade de troca catiônica, alta capacidade de adsorção aniônica e alta acidez (FONTES et al., 2001).

A fase sólida do solo é constituída pela matéria mineral e pela matéria orgânica. A fração mineral é formada pelas partículas de diferentes dimensões, originadas da intemperização dos materiais de origem. A parte orgânica é formada de restos de plantas e de animais em decomposição ou já decompostos. A matéria mineral inclui fragmentos de rocha, minerais primários e minerais secundários, ambos em formas e dimensões extremamente variáveis (OLIVEIRA; BRIGHENTI, 2011).

A fase líquida do solo é composta pela mistura de água, sais minerais e moléculas de baixa massa molar, como aminoácidos, peptídeos, açúcares e ácidos orgânicos fracos. As substâncias húmicas também são encontradas no solo. Essa mistura tem o nome de solução do solo. É na solução do solo que também são encontradas as moléculas dos herbicidas, as quais estão sujeitas a inúmeras reações, segundo as propriedades da solução, como potencial hidrogeniônico, força iônica e o potencial redox (OLIVEIRA; BRIGHENTI, 2011).

O solo tem como limite superior a atmosfera. Os limites laterais são os contatos com os corpos d'água superficiais, rochas, gelos, áreas com cobertura de materiais detríticos inconsolidados, aterros ou com terrenos sob espelhos d'água permanente. O solo passa gradualmente do seu limite inferior em profundidade, para rochas consolidadas ou materiais 
saprolíticos ou sedimentos que não apresentam sinais da influência de atividade biológica. Os materiais subjacentes (não-solo) contrastam com o solo, pelo decréscimo nítido de constituintes orgânicos, decréscimo de alterações e decomposição dos constituintes minerais, contudo, pelo predomínio das propriedades mais relacionadas ao substrato rochoso.

\subsection{Sistema plantio direto}

É um sistema de produção conservacionista, que se contrapõe ao sistema tradicional de manejo, envolvendo técnicas de produção que preservem a qualidade ambiental. Caracterizase pela ausência de preparo do solo e na cobertura permanente do terreno pela realização de rotação de cultura (EMBRAPA, 2011).

Com a implantação deste sistema, diminuem-se alguns problemas como o uso continuado de grades de discos, o que causa degradação na estrutura do solo, formação de camadas compactas, encrostamento superficial e perdas por erosão. O sistema plantio direto proporciona efeitos significativos na conservação e melhoria do solo, da água, no aproveitamento dos recursos e insumos como fertilizantes, proporcionando redução de custos, estabilidade de produção e melhoria das condições de vida do produtor rural e da sociedade (EMBRAPA, 2011).

\subsection{Avaliação de experimentos de campo}

Nas avaliações referentes aos danos causados pela ação de herbicidas tanto na cultura quanto nas plantas invasoras, é indispensável uma adequada descrição ou representação do que ocorre em condições de campo. A partir destas avaliações, o pesquisador pode emitir opinião ou conceito sobre a aceitabilidade ou não do desempenho do produto que está sendo testado.

Tais avaliações podem ser feitas de forma direta, determinando a altura, os acúmulos de matéria seca ou fresca, densidades e a produtividade da cultura (soja, feijão, milho etc). Quanto às plantas invasoras, normalmente são avaliados os acúmulos de matéria seca ou fresca, porcentagens de cobertura do solo e densidade populacional. As avaliações indiretas estão relacionadas às estimativas visuais das porcentagens de controle e das características diretas como a biometria da planta (SBCPD, 1995).

A vantagem da avaliação direta está na exatidão, de forma que permitem determinar precisamente o valor de uma característica avaliada. A maior desvantagem está na lentidão das avaliações, o que torna obrigatório trabalhar com amostras relativamente pequenas. Quando se 
estimam visualmente características relacionadas à cultura ou às plantas invasoras, ocorre um erro inerente ao processo. Ou seja, a exatidão do processo depende do treinamento e da experiência prévia do avaliador e esta dependência constitui a maior limitação da qualidade dos resultados obtidos. Contudo, esse tipo de avaliação é de rápida execução e permite que se obtenham valores médios para toda a área da parcela, melhorando a representatividade das estimativas (SBCPD, 1995).

Para contornar o uso destes sistemas de avaliação, o uso de sistemas duplos de avaliação se faz necessário. Inicialmente, deve-se estimar visualmente as porcentagens de controle das plantas invasoras e as porcentagens de injúria (redução de crescimento, área foliar ou estande) da cultura de interesse, sem que haja, a princípio, preocupação quanto ao controle. Estas avaliações descrevem objetivamente o que foi verificado em campo (SBCPD, 1995).

Baseado nos resultados verificados e do conhecimento prévio do pesquisador quanto à cultura, ao herbicida e à planta invasora em estudo, ele poderá emitir um conceito sobre a aceitabilidade ou não dos resultados obtidos. Deve destacar que os conceitos podem também ser aplicados a resultados obtidos pela avaliação direta (medição), assim como da área foliar e densidade de plantas (SBCPD, 1995).

\subsubsection{Aplicação dos tratamentos}

A aplicação de herbicidas é geralmente uma estratégia para combater infestação por plantas invasoras, entretanto, o uso contínuo e intensivo eleva a preocupação sobre a sustentabilidade da fertilidade do solo. A interação de herbicidas com vários tipos de solo não apenas muda a eficácia do herbicida contra o crescimento de infestantes, mas também pode afetar o ciclo de vários nutrientes, refletindo em termos de variação na atividade das enzimas do solo (SINGH; GHOSHAL, 2013).

O controle efetivo de plantas invasoras é um componente essencial para um melhor aproveitamento da produção da soja e de outras culturas. A capina manual, que é o método mais comum no controle de plantas invasoras não é, às vezes, possível devido à indisponibilidade de mão-de-obra no período necessário. Para prevenir esses problemas, fazendeiros têm adotado herbicidas como alternativa para a capina, entretanto, consideráveis alterações ocorrem na safra em resposta à aplicação de herbicidas (PORNPROM, SUKCHAROENVIPHARAT e SANSIRIPHUN, 2010).

Uma vez que o pesticida é lançado na matriz do solo, seu efeito irá depender das características do solo e do próprio pesticida (GEVAO, SEMPLE; JONES, 2000). A reatividade 
com o compartimento biológico do solo é uma das principais interações entre os constituintes do solo e pesticidas, que são conhecidos por serem degradados microbiologicamente ou mineralizados por fungos telúricos (HERNÁNDEZ RODRIGUEZ et al., 2006; RONHEDE et al., 2007) e bactérias (DONG et al., 2005; QIU et al., 2006).

\subsection{Contaminação ambiental e intoxicação}

Os dados de intoxicação humana e de contaminação ambiental provocados pelo uso generalizado de pesticidas são preocupantes. O chamado uso seguro, nome usado pela indústria para mascarar os perigos de seus produtos, é impossível de ser praticado, seja pela dificuldade de se seguir todas as recomendações de segurança, seja pela própria capacidade destes métodos de fornecer segurança. Além disso, a intoxicação crônica, é outro mal que advêm do contato direto com pesticidas, dentre outros tipos de exposições. O uso massivo de pesticidas promovido pela expansão do agronegócio contamina alimentos, águas e até o ar (LONDRES, 2011).

Em agronomia, denomina-se deriva a dispersão de pesticidas no meio ambiente através do vento ou das águas, quando estes não atingem o alvo (a lavoura) e, consequentemente, contaminam o entorno. A chamada deriva técnica é a deriva que acontece sempre, ou seja, mesmo quando todos os procedimentos técnicos da aplicação são seguidos. É uma situação estimada em pelo menos $30 \%$ do produto aplicado, em alguns casos até $70 \%$, ou seja, não existe uso de pesticida sem a contaminação do meio ambiente que circunda a área tratada (LONDRES, 2011).

Um dos maiores perigos representados pelos pesticidas diz respeito aos efeitos que provocam na saúde humana. As pessoas mais expostas aos perigos de contaminação pelos agrotóxicos, outra denominação dada aos pesticidas, são aquelas envolvidas diretamente com eles no campo. Há os aplicadores, preparadores de caldas e responsáveis por depósitos, que têm contato direto com os produtos e há também os trabalhadores que têm contato indireto com as formulações ao realizar as capinas, roçadas, colheitas etc. Este último grupo é considerado o de maior risco, uma vez que o intervalo de reentradas nas lavouras não costuma ser respeitado e os trabalhadores, geralmente, não usam proteção (LONDRES, 2011).

Por fim, os tipos de intoxicação causados pela exposição aos agrotóxicos são a aguda, causada pela rápida exposição a doses elevadas do veneno; subaguda, causada pela exposição moderada aos produtos de alta ou média toxicidade; crônica, caracterizada pelo surgimento 
tardio de sintomas, surgindo apenas após meses ou anos de pequena exposição a vários tipos de produtos tóxicos.

\subsection{Problemática do uso de pesticidas na agricultura}

Os pesticidas podem ser aplicados em pré-plantio incorporados ao solo, em préemergência ou em pós-emergência, considerando-se a deriva e a evaporação negligenciáveis, no pré-plantio e na pré-emergência, todo o pesticida aplicado atinge o solo. Na pós-emergência, parte do pesticida fica retido nas folhas e o restante pode atingir o solo. A seguir são descritos alguns processos que determinam o destino dos pesticidas no ambiente.

\subsubsection{Retenção}

Os pesticidas aplicados nas lavouras, tanto em pré quanto em pós-emergência, na maioria das vezes, tem como destino final o solo. Ao atingir o solo, tais compostos podem ser retidos pelos coloides ou permanecer na solução do solo. A retenção está relacionada a habilidade do solo em reter uma molécula orgânica, evitando que ela se mova tanto para dentro como para fora da matriz do solo. A retenção constitui um processo de adsorção e absorção pela matriz do solo, quando inclui as plantas e o processo de degradação por micro-organismos. A retenção é então controlada por transformações químicas e biológicas, influenciadas pelo transporte das moléculas orgânicas para a atmosfera, águas subterrâneas e superficiais. Assim, a retenção é o fator que determina a eficiência dos pesticidas aplicados no solo (OLIVEIRA; BRIGHENTI, 2011).

A adsorção dos pesticidas é definida por Koskinen e Harper (1990) como o acúmulo da molécula orgânica na interface de duas fases, do tipo solo-água ou solo-ar. Geralmente, referese a processos reversíveis, que envolvem a atração das substâncias pela superfície das partículas do solo e sua retenção por determinado tempo. Este tempo de retenção depende da afinidade da molécula.

\subsubsection{Lixiviação}

O movimento descendente dos herbicidas na matriz solo ou com água do solo é chamado de lixiviação ou percolação. Para ser lixiviado, o herbicida deve estar na solução do solo, livre 
ou adsorvido a pequenas partículas, como argilas, ácidos húmicos e fúlvicos de baixa massa molecular, aminoácidos, peptídeos e açúcares, entre outros (OLIVEIRA; BRIGHENTI, 2011).

A intensidade de lixiviação de um herbicida é função das características físico-químicas e das características do solo e do clima. Os fatores que afetam a lixiviação dos herbicidas são sua retenção pelos coloides do solo, o pH e o teor de água do solo, persistência no solo e potencial de remobilização, a topografia ou declividade da área, a intensidade da chuva ou irrigação após aplicação e o manejo do solo. Quanto maior a retenção do produto pelos coloides do solo, menor sua dessorção e menor a quantidade do produto em solução ser lixiviado. Para a maioria dos herbicidas, o teor de matéria orgânica do solo está diretamente relacionado à adsorção e ao seu movimento. $\mathrm{O}$ pH do solo apresenta efeito variável dependendo do grupo químico do herbicida. A capacidade de retenção de água do solo tem efeito direto na lixiviação dos herbicidas, pois reduz a adsorção das moléculas. O teor de água é importante quando é aplicado em solo úmido, onde em seguida ocorre chuva ou irrigação (OLIVEIRA; BRIGHENTI, 2011).

Os fatores relacionados aos herbicidas que afetam seu movimento no solo são: as características físico-químicas das moléculas, a solubilidade em água, a formulação e os aditivos usados. Quanto maior a solubilidade de um herbicida, mais facilmente ele estará dissolvido na solução do solo e poderá ser arrastado (OLIVEIRA; BRIGHENTI, 2011).

\subsubsection{Degradação}

O herbicida ideal é aquele que permanece ativo no ambiente por tempo suficientemente longo para o controle das plantas invasoras em determinadas culturas, mas que não causa injúria às culturas susceptíveis (OLIVEIRA; BRIGHENTI, 2011).

A degradação de um herbicida refere-se à mudança na natureza química da molécula por processos químicos como a fotodegradação, a oxido-redução, a hidrólise, a formação de sais insolúveis em água e complexos ou como também por processos biológicos (degradação biológica). De modo geral, a degradação é importante por reduzir o nível de resíduo dos pesticidas no solo (OLIVEIRA; BRIGHENTI, 2011).

Fotodecomposição ou fotólise é a degradação de uma molécula pela radiação solar. As moléculas dos herbicidas podem absorver energia em comprimentos de onda particulares para cada molécula. Em alguns casos, a energia absorvida é dissipada pela quebra da ligação química da molécula. Alguns herbicidas (trifuralina, napropamida e paraquat) podem sofrer rápida fotodecomposição, enquanto que as feniluréias podem sofrer fotodecomposição quando 
submetidas a longos períodos de exposição à luz. Os herbicidas que agem no solo e que são rapidamente fotodecompostos precisam ser incorporados no solo para serem efetivos. Por um lado, a fotodecomposição pode ser benéfica, reduzindo a persistência excessiva de resíduos no solo, por outro lado, pode ser indesejável, pois reduz a eficiência de controle das plantas invasoras após a aplicação (OLIVEIRA; BRIGHENTI, 2011).

Para um herbicida ser degradado, química ou biologicamente, esse deve estar na solução do solo ou fracamente adsorvido. Quando fortemente adsorvido pelos colóides do solo, tornase de difícil degradação pelos micro-organismos do solo ou por reações químicas diversas (OLIVEIRA; BRIGHENTI, 2011).

\subsubsection{Volatilização}

É o processo pelo qual as moléculas dos herbicidas passam do estado líquido para o estado de vapor. Esse processo é outra fonte significativa de perda de herbicidas, sendo função da pressão de vapor e das propriedades químicas do produto. Para alguns herbicidas, esse processo pode ser tão intenso que, depois de sua aplicação, há necessidade de imediata incorporação ao solo, para que não se percam substâncias na forma de vapor para a atmosfera (OLIVEIRA; BRIGHENTI, 2011).

A elevação da temperatura na superfície do solo intensifica a perda por volatilização dos herbicidas, principalmente quando combinados com a alta umidade do solo. Da mesma forma, a ação dos ventos sobre a superfície tende a favorecer a volatilização pelo arrastamento dos vapores que se formam, reduzindo a concentração nas camadas mais próximas do solo (OLIVEIRA; BRIGHENTI, 2011).

Herbicidas mais voláteis têm menor persistência, apresentando assim, menor efeito residual no solo. Por outro lado, elevada volatilização resulta em fácil escape para a atmosfera. De modo geral, um herbicida com elevada pressão de vapor está menos sujeito a causar contaminação no solo do que outro com baixa pressão de vapor. Um herbicida volátil, usado incorporado ao solo, pode persistir por mais tempo do que quando presente na superfície do solo (OLIVEIRA; BRIGHENTI, 2011).

\subsubsection{Escoamento superficial (runoff)}

O movimento dos herbicidas na superfície do solo, de áreas tratadas para áreas não tratadas, após fortes chuvas e a própria enxurrada, é chamado de runoff. Este processo afeta 
com grande intensidade os herbicidas aplicados diretamente ao solo, pois estes estão sujeitos as intempéries ao longo de todo o processo, ou seja, antes e/ou após o plantio da cultura (PIRES et al., 1995; FONTES et al., 2003).

O herbicida removido pode estar na solução ou adsorvido às partículas do solo. Logo, fatores que favorecem a erosão, como exemplo, o manejo incorreto do solo, ocasionam perdas dos herbicidas por escoamento superficial. Além destes fatores, a natureza e a dose das aplicações afetam na quantidade do produto a ser removido (OLIVEIRA; BRIGHENTI, 2011).

A erosão do solo causa vários problemas à exploração agropecuária, não só pela elevação dos custos finais de produção, mas também por promover a poluição dos recursos hídricos e a redução da capacidade de armazenamento de reservatórios, devido à sedimentação, à redução do potencial de geração de energia elétrica, à elevação dos custos de tratamento de água, assim como dos custos de drenagem dos cursos d'água e reservatórios (SILVA; PRUSKI, 1997; CASTRO et al., 1993).

\subsection{Translocação de herbicidas no meio ambiente}

O solo é, normalmente, o destino final dos pesticidas aplicados nas culturas de interesse. Com uma sequência de aplicações, diversos pesticidas alcançam o solo, devido a aplicação direta e/ou pela lavagem das folhas. Entretanto, quantidades de pesticidas, particularmente no caso de pesticidas foliares, são interceptados e absorvidos pelas folhas das plantas invasoras e/ou da própria cultura. Plantas contaminadas por pesticidas podem retornar ao solo durante o ciclo da cultura (senescência foliar) ou depois da colheita sob a forma de resíduos da cultura. $\mathrm{O}$ destino dos resíduos de pesticidas no solo vindos de material vegetal é geralmente ignorado e desconhecido. O pesticida e seu produto de degradação pode ser lançado no solo durante a decomposição da planta com uma contribuição lenta destas substâncias para o solo e um adicional risco de contaminação ambiental (DOUBLET, MAMY; BARRIUSO, 2009).

Existem no Brasil aproximadamente 366 ingredientes ativos registrados para uso agrícola, pertencentes a mais de 200 grupos químicos diferentes, que dão origem a aproximadamente 1.458 formulações para venda no mercado de agrotóxicos. São inseticidas, fungicidas, herbicidas, nematicidas, acaricidas, rodenticidas, moluscidas, formicidas, reguladores e inibidores do crescimento. Sendo que os herbicidas representam $48 \%$ deste mercado, seguidos pelos inseticidas (25\%) (LONDRES, 2011).

É de conhecimento cientifico que as pragas agrícolas possuem a capacidade de desenvolver resistência às formulações aplicadas, o que, com o passar do tempo, faz com que 
o agrotóxico perca sua eficácia, estimulando o agricultor a aumentar as doses aplicadas ou recorrer a novos produtos.

Outro elemento importante em todo o processo de combate a pragas agrícolas é o desequilíbrio ambiental provocado, que leva ao surgimento de novas pragas e até a alteração do comportamento das plantas, ou seja, aquelas que não causavam danos às lavouras, podem se comportar como invasoras e atacar as plantações.

Logo, é de fundamental importância que se utilizem cada vez menos herbicidas nas plantações, que se busque por formulações ambientalmente menos tóxicas em contrapartida ao desenvolvimento de novos compostos pelas indústrias.

\subsection{Alelopatia}

A alelopatia é uma interação entre seres vivos em que ao menos um dos indivíduos envolvidos é prejudicado, enquanto outro pode ser beneficiado ou não por esta interação. Segundo Marashim-Silva e Aquila (2006), a alelopatia é uma forma de interação bioquímica entre vegetais, que consiste em um meio de defesa químico, além de um fator de estresse ambiental para várias espécies. Entretanto, quando há interação entre indivíduos da mesma espécie, o processo é chamado de autoalelopatia. A alelopatia é conceituada como "qualquer processo envolvendo metabólitos secundários produzidos pelas plantas e micro-organismos que influencia o crescimento e o desenvolvimento de sistemas agrícolas e biológicos (incluindo animais)" (Sociedade Internacional de Alelopatia, 1996). Nesse sentido, na interação entre plantas da mesma espécie há a liberação de algum metabólito secundário denominado aleloquímico ou composto alelopático, que exerce algum tipo de efeito inibidor no crescimento e no desenvolvimento da outra planta, caracterizando a interferência direta, que, no caso, o principal efeito é a redução na quantidade de produto produzido (produtividade) (CARVALHO, 2013).

A produção de metabólitos secundários pelas plantas não tem função apenas de inibir outras plantas. As funções ecológicas da alelopatia em plantas são basicamente a atração de agentes polinizadores e dispersores, uma forma de proteção natural contra herbívoros e patógenos, além da relação planta-planta, característica da competição entre indivíduos da mesma espécie por algum recurso ambiental limitado (nutriente, água, luz e espaço), importante na sucessão das espécies. Muitos metabólitos secundários são produzidos nas flores, conferindo cor e odor às mesmas, atuando como atrativo para agentes polinizadores e dispersores. Alguns compostos produzidos pelo metabolismo secundário das plantas são tóxicos a animais, insetos 
etc, atuando como repelente desses inimigos naturais. Também se deve destacar que, em teoria, alguns compostos liberados podem atuar como condicionadores de ambiente, atuando na sucessão de espécies vegetais (CARVALHO, 2013).

Os metabólitos secundários são produzidos por diferentes partes da planta, dependendo, inclusive, da espécie em questão. Normalmente, os metabólitos secundários com potencial alelopático (aleloquímicos) são produzidos em maior quantidade nas folhas. A quantidade de aleloquímicos produzida varia em função da espécie e é influenciada por fatores bióticos e abióticos. Há espécies em que algum fator de estresse, biótico ou abiótico, pode estimular a produção de determinado composto; porém, em outra espécie pode ocorrer inibição na produção do composto (CARVALHO, 2013). Em um dos estudos em nosso laboratório verificou-se que as sementes da planta Canavalia ensiformis apresentam maior quantidade de aleloquímicos (MENDES, 2011)

Os aleloquímicos produzidos pelas plantas derivam de quatro vias metabólicas principais: via ácido chiquímico, importante para produção de compostos fenólicos e compostos nitrogenados; via ácido malônico, importante para a produção de compostos fenólicos; via ácido mevalônico, importante para a produção de terpenos e via ácido 3fosfoglicérico (3-fosfoglicerato). Através destas quatro vias são produzidos metabólitos secundários com potencial alelopático pertencentes a três grupos: terpenos, podem atuar como inseticidas, como repelentes ou atrativos (óleos essenciais); compostos fenólicos, atuam como herbicidas e inseticidas, atrativos e repelentes e os compostos nitrogenados, atuam como tóxicos (nicotina, morfina...). As plantas liberam os aleloquímicos por quatro vias: volatização, liberação de compostos voláteis como pireno, limoneno e piretróides; lixiviação, liberação de compostos exsudados (compostos fenólicos, alcaloides e nicotina) normalmente pelas folhas e/ou outros órgãos que são lavados da planta, por meio da chuva ou irrigação; liberação de compostos na forma líquida (aminoácidos, nucleotídeos) através da raízes, diretamente no solo e por decomposição de restos vegetais, liberação de compostos líquidos (flavonoides como a antocianina) gradativamente à decomposição vegetal (CARVALHO, 2013).

\subsection{Apoptose}

Apoptose foi originalmente definida em 1972 baseada em uma mudança morfológica específica que ocorre durante a morte celular geneticamente controlada pelos estímulos externos e /ou internos do ambiente (KERR et al., 1972). De um ponto de vista simplificado, a apoptose está associada com à condensação da cromatina, contração celular, membrana 
plasmática, à clivagem internucleossomal do DNA e à formação de corpos apoptóticos e finalmente a absorção e degradação em lisossomos fagocíticos de células adjacentes (CLARKE; CLARKE, 1995).

Nos últimos anos, um paralelo tem sido traçado entre os processos apoptóticos em mamíferos e a hipersensibilidade nas plantas (RUEDA et al., 2011). Funcionalmente e mecanisticamente, duas formas de morte celular são reconhecidas. Em animais, a morte apoptótica e necrótica foram definidas usando critérios morfológicos, bioquímicos e moleculares mais atuais. A necrose é um mecanismo de morte celular que envolve o aumento de tamanho das células e organelas, seguida pela ruptura da membrana plasmática e liberação do material citoplasmático (GOLSTEIN et al., 2003). A morte celular é crucial para vários eventos biológicos, tais como a morfogênese e a eliminação de células nocivas (CLARKE, 1990; ARAKAWA et al., 2015). Apoptose é a mais importante forma de morte celular que é conduzida pela família das cisteínas proteases chamadas de caspases (TSUJIMOTO, 2003). Entretanto, a morte celular é também induzida por outros mecanismos, incluindo a autofagia da célula (SHIMIZU et al., 2004; EISENBERG-LERNER, BIALIK; SIMON, 2009) e a necrose programada (ZHOU; YUAN, 2014, ARAKAWA et al., 2015).

Condições de estresse envolvem a presença de fatores externos que exercem uma influência negativa sobre o desenvolvimento ideal da planta (Rueda et al, 2011). As formas de estresse podem ser bióticas e abióticas (HAHN, 1996; HAMMERSCHMIDT, 1999; GRAYER; KOKUBUN, 2001; ZHAOA et al., 2005). Os fatores abióticos tais como os elementos tóxicos e os herbicidas tem efeito prejudicial sobre as plantas (RUEDA et al., 2011).

Existem essencialmente três situações em que se pode esperar que ocorra a apoptose:

- Suicídio celular utilitário: a morte de uma única célula ocorre em benéfico da maioria, ou seja, células perfeitamente saudáveis são instruídas pelo ambiente em que se encontram, a se autodestruir, pois existem células demais presentes, ou é necessário mais espaço para reposicionamento/reorganização dos tecidos. Nesta situação de apoptose ocorre a remoção de células saudáveis, não existindo a indução de qualquer dano;

- Senescência: as células reconhecem que estão velhas e dão início a um processo de morte programada. Neste mecanismo, as células reconhecem o envelhecimento de outras células e sinalizam para que ocorra o início da apoptose; 
- Dano celular: as células detectam níveis muito baixos de dano a estruturas vitais do DNA ou das membranas, entretanto, não tentam reparar estes danos, cometendo suicídio.

A apoptose é chamada de morte programada da célula e este tipo de morte celular é considerada mais complexa do que a necrose, já que envolve processos controlados e programados para cada célula individual (ABBOTT, 2007).

\subsection{Extração de compostos fenólicos em plantas}

A extração de compostos fenólicos de materiais vegetais é influenciada pela natureza química desses compostos, pelo método de extração empregado, pelo tamanho das partículas da amostra, pelo tempo de armazenamento, assim como pela presença de interferentes (ROCKENBACH, 2008).

A solubilidade dos compostos fenólicos depende da natureza química da planta, que pode conter desde substâncias simples até altamente polimerizadas. Possíveis interações dos compostos fenólicos com outros componentes da planta, como carboidratos e/ou proteínas podem levar à formação de complexos insolúveis. A solubilidade dos compostos fenólicos também é afetada pela polaridade dos solventes utilizados, portanto, é muito difícil desenvolver um procedimento de extração apropriado para todos os compostos fenólicos solúveis no solvente utilizado (ROCKENBACH, 2008).

\subsection{Extração assistida por micro-ondas}

A extração por auxílio de micro-ondas é uma técnica recente de extração que pode oferecer alta reprodutibilidade em menor tempo, manipulação simplificada, reduzido consumo de solvente e baixa energia empregada sem diminuição do rendimento dos compostos alvos (LI ET AL., 2010; SILVA, AZEVEDO; REZENDE, 2016).

O processo de extração usa a energia das micro-ondas para aquecer solventes de forma eficiente e rápida (GAROFULIC et al., 2013). A matriz planta já contém uma quantidade significativa de água que absorve fortemente energias micro-ondas, com consequente superaquecimento interno, o que causa rompimento da célula, facilitando o processo de extração. Além disso, a migração de íons dissolvidos aumenta a penetração do solvente na 
matriz e, consequentemente, aumento no rendimento da extração (WANG; WELLER, 2006;.ARMENTA et al., 2008).

Para a quantificação de uma espécie química inorgânica, em geral, faz-se o uso da mineralização ácida, que exige trabalho e tempo, além de sujeitar o processo a perdas do analito e/ou contaminações. A energia micro-ondas é uma radiação eletromagnética não-ionizante (frequência de 300-300000 MHz) que provoca movimento das espécies em solução pela migração de íons e/ou rotações de dipolo, ocasionada pelo elevado número de alterações do campo eletromagnético. Este mecanismo de aquecimento induzido vem da interação entre as moléculas do solvente e da radiação eletromagnética gerada pelas micro-ondas (ARRUDA; SANTELLI, 1997).

\subsubsection{Extração de compostos fenólicos assistida por micro-ondas}

A aplicação de micro-ondas para extração de compostos fenólicos presentes em plantas requer um processo de otimização considerável dos parâmetros operacionais da técnica tais como temperatura, tempo e potência das micro-ondas. Esta técnica é ambientalmente amigável, pois todo o processo apresenta vantagens em comparação com as técnicas tradicionais de extração (WANG, DING; REN, 2016).

O preparo da amostra tem um papel essencial e crucial no processo analítico como um todo, especialmente quando se trata de amostras sólidas. Diversos equipamentos não são adequados para analisar tais matrizes diretamente e algumas etapas de pré-tratamento são necessárias para extrair e enriquecer os analitos, especialmente em amostras ambientais. Muitos dos problemas observados no preparo da amostra estão normalmente ligados ao tempo, consumo de reagentes, perdas de analito e contaminação. De modo ideal, o preparo de amostras deve ser rápido, preciso e ambientalmente amigável (WANG, DING; REN, 2016).

$\mathrm{O}$ uso das energias micro-ondas para o preparo de amostras foi inicialmente proposto em 1975 (ABU-SAMRA, MORRIS; KOIRTYOHANN, 1975). O aquecimento por energia micro-ondas age diretamente na molécula por condução iônica e rotação de dipolos. A condução de íons está relacionada com a migração eletroforética dos íons e elétrons sobre a influência de um campo eletromagnético produzido pela radiação. A rotação de dipolo é um movimento ordenado das moléculas polares de modo que se alinhem ao campo elétrico. Para que o alinhamento com o campo elétrico seja aplicado é necessário que a molécula possua um momento dipolar. Com a retirada do campo elétrico as moléculas retornam ao seu estado 
desordenado e a energia que foi absorvida durante a orientação nos dipolos (alinhamento) é dissipada na forma de calor, aquecendo o meio (TSUKUI; REZENDE, 2014; CAMEL, 2000; ESKILSSON; BJÖRKLUND, 2000).

A extração de compostos orgânicos por irradiação de micro-ondas surgiu com a pesquisa de Ganzler et al. (1986). Desde então, a técnica alcançou desenvolvimento e tem sido usada em química analítica. Diversas aplicações para extração de compostos orgânicos em amostras de alimento e ambientais têm sido publicadas (RAMALHOSA et al., 2012; FUJITA et al., 2009; MORET, PURCARO; CONTE, 2010). Uma das principais vantagens do uso da extração assistida por micro-ondas (MAE, do inglês, Microwave-Assisted Extraction) é a redução do tempo de extração, que é atribuído pela diferença de aquecimento pelas micro-ondas e o aquecimento convencional. Adicionalmente, MAE permite o acoplamento on-line com outras técnicas analíticas, possibilitando assim a análise de múltiplas amostras (WANG, DING; REN, 2016). A MAE é considerada uma técnica ambientalmente amigável em relação aos métodos convencionais de extração e tem como principais vantagens, na perspectiva da química verde, o tempo reduzido em alguns procedimentos, o que consequentemente poupa energia; o uso de menos solvente, o que reduz a geração de resíduos e evita a poluição; a realização de método de baixo custo com um aumento de produtividade; a possibilidade de acoplamento online com outras etapas analíticas e automatização total ou parcial do processo analítico, com redução do tempo de análise, diminuição da perda de analitos e aumento da segurança do pesquisador (WANG, DING; REN, 2016).

\subsubsection{Eficiência da extração-assistida por micro-ondas}

Geralmente, os equipamentos de MAE (Microwave-Assisted Extraction) compreendem frascos para extração sob pressão e temperatura controlada ou um forno de micro-ondas focalizado à pressão atmosférica. Estas duas tecnologias são chamadas de PMAE (Pressurized Microwave-assisted Extraction) e FMAE (Focused Microwave-assisted Extraction), respectivamente (WANG, DING; REN, 2016).

O sistema para PMAE consiste de um magnetron (gerador da radiação), um forno (onde os frascos são colocados) e um dispositivo que monitora a temperatura e a pressão. Em PMAE, as extrações são conduzidas em frascos pressurizados sob radiação. $\mathrm{O}$ aumento da temperatura e da pressão acelera o processo de extração devido à capacidade do solvente em absorver energia das micro-ondas. O sistema fechado oferece extração rápida e eficiente, com um menor 
consumo de solvente, mas suscetível a perdas de analitos por volatilização e geralmente caro devido à resistência do sistema à tensão e altas pressões (ZHANG, YANG; WANG, 2011).

A FMAE envolve um sistema aberto que supre as deficiências do sistema fechado, uma delas, a segurança nos ensaios. O modelo do extrator é baseado nos princípios da extração convencional por Soxhlet modificado para facilitar a acomodação da amostra no compartimento em que a irradiação incide. O aquecimento do solvente de extração usado em FMAE pode ser conseguido por aquecimento elétrico, que independe da polaridade do solvente (LUQUEGARCIA; CASTRO, 2004; WANG, DING; REN, 2016). É considerado mais apropriado para extração de compostos termolábeis devido apenas à parte da célula de extração ser diretamente exposta à radiação das micro-ondas (WANG, DING; REN, 2016). Neste trabalho usou-se o sistema PMAE.

\subsubsection{Extração ambientalmente amigável}

A redução do volume de solvente e do tempo de extração são significativas na MAE. Métodos convencionais de extração são associados com o uso de grandes volumes de solvente, longo tempo de extração e risco de degradação de compostos termolábeis. Logo, o rápido processo de extração é obviamente importante na MAE. Deve eficientemente solubilizar os analitos de interesse e ter excelente propriedade de absorver micro-ondas. O fator de dissipação ( $\tan \delta$ ) (Equação 1) é a medida da habilidade do solvente em absorver energia micro-ondas e dissipar essa energia na forma de calor (CAMEL, 2000; BALLARD et al.,2010). O fator de dissipação é expresso pela Equação 1:

$$
\tan \delta=\mathrm{e}^{\prime \prime} / \mathrm{e}
$$

sendo: e" é o fator de perda dielétrica, indicativo da eficiência da conversão da radiação eletromagnética a aquecimento e e' é a constante dielétrica, que descreve a habilidade da molécula em ser polarizada pelo campo elétrico. Solventes orgânicos polares tem altos valores de $\tan \delta$ e são ideais para promover as reações com as micro-ondas (LARHED; HALLBERG, 2001).

Um dos principais objetivos da química verde em relação ao preparo de amostra é desenvolver uma extração alternativa ao uso de solventes orgânicos tóxicos, ou seja, uma metodologia ambientalmente limpa, que favoreça o desenvolvimento de metodologias que utilizem solventes ambientalmente amigáveis (WANG, DING; REN, 2016). 


\subsubsection{Extração assistida por micro-ondas: uso da água como solvente de extração}

As soluções aquosas ou vapores são usados como 'solvente verde' para extrair poluentes orgânicos em matrizes sólidas, como o ibuprofeno, naproxeno, cetoprofeno e diclofenaco em amostras de lodo de esgoto através da MAE usando água como extratante, tendo como diferencial a redução do efeito da matriz comparado às extrações feitas utilizando solventes orgânicos (DOBOR et al., 2010).

$\mathrm{Na}$ análise de amostras ambientais, níveis traço de pesticidas (piretroides, triazinas e organoclorados etc) podem ser extraídos via MAE. Além disso, o uso de soluções aquosas como solvente têm fundamental importância na extração de metabólitos secundários em alimentos e em plantas (aleloquímicos) (WANG, DING; REN, 2016).

Neste trabalho, o uso da água como solvente não gerou resíduos tóxicos, permitindo que o material vegetal extraído (folhas) pudesse ser utilizado como fonte de matéria orgânica quando descartado diretamente no solo.

\subsection{Princípios básicos de planejamento e análise de experimentos}

No planejamento de qualquer experimento, devem ser avaliados quais os fatores e as respostas de interesse. Os fatores são as variáveis independentes que podem ser controladas, podendo ser qualitativos, como o fabricante de um solvente ou quantitativos, como a temperatura.

As respostas são as variáveis de saída do sistema (dependentes), alvo do estudo, e que serão ou não afetadas pelas alterações dos fatores.

\subsubsection{Conceitos gerais de experimentação}

A seguir apresentam-se alguns conceitos e termos fundamentais para aplicação das técnicas de planejamento e análise de experimentos:

Variável de resposta: são as variáveis dependentes que sofrem algum efeito nos testes, quando há alteração dos níveis dos fatores.

Fatores: são as variáveis independentes que sofrem alteração e produzem efeito na variável de resposta. 
Níveis dos fatores: em um planejamento com dois níveis, são as condições de operação dos fatores. Os níveis são identificados por nível baixo (-1) e nível alto $(+1)$.

Tratamento ou ensaio: é a combinação dos níveis dos fatores, ou seja, é cada um dos experimentos definidos no planejamento.

Efeito principal: é a diferença média observada na resposta quando se passa de um nível a outro.

Efeito de interação: é a metade da diferença entre os efeitos principais de um fator nos níveis de outro fator.

Matriz experimental: é o plano formal construído para conduzir os experimentos. Nesta matriz estão os fatores e os níveis dos fatores.

Aleatorização: é o processo de definir a ordem dos tratamentos da matriz experimental, através de sorteio ou por limitações especificas dos testes. A aleatoriação nos experimentos é realizada para balancear os efeitos produzidos pelos fatores não-controláveis nas respostas analisadas e para atender aos requisitos dos métodos estatísticos, que exigem que os componentes do erro experimental sejam variáveis aleatórias independentes.

Repetição: é o processo de repetir cada uma das combinações (linhas) da matriz experimental sob as mesmas condições de experimentação. Segundo Montgomery (1991), este conceito permite encontrar uma estimativa do erro experimental, que é utilizado para determinar se as diferenças observadas entre os dados são estatisticamente significativas.

\subsubsection{Procedimentos para condução de experimentos}

Antes de iniciar qualquer experimentação, é importante estabelecer os parâmetros a serem avaliados nos ensaios. A essência de um bom planejamento consiste em projetar um experimento de forma que ele seja capaz de fornecer exatamente o tipo de informação que se procura. Dentre os passos a serem avaliados durante a condução do experimento, em geral, podem-se citar: a triagem das variáveis; a avaliação da influência das variáveis; a construção do modelo empírico; a otimização (por RSM - metodologia da superfície de resposta). Tendo selecionado os fatores importantes, avaliar quantitativamente a influência sobre a resposta de interesse, assim como as possíveis interações entre os fatores é o próximo passo (GALDÁMEZ, 2002; NETO, SCARMINIO; BRUNS, 2001). 


\subsubsection{Técnicas de análise de experimentos}

As técnicas de planejamento de experimentos são principalmente utilizadas nas etapas preliminares de um projeto. Nesta etapa, um dos principais problemas é determinar a influência de uma ou mais variáveis sobre uma outra variável de interesse. Quando se quer avaliar o efeito de dois ou mais fatores na resposta, e cada um deles com dois ou mais níveis, usam-se técnicas clássicas de planejamento, como por exemplo: o planejamento fatorial completo, fatorial fracionado ou experimentos com pontos centrais (GALDÁMEZ, 2002).

\subsubsection{Planejamento fatorial}

O planejamento fatorial é utilizado quando se quer definir os fatores mais importantes no processo e estudar seus efeitos sobre a variável resposta. Para ilustrar o procedimento desta técnica, consideremos um experimento com dois fatores (A e B), cada um deles com $a$ níveis para o fator A e $b$ níveis para o fator B. Assim, nesse experimento existem $a b$ combinações de teste. A matriz de planejamento para o experimento fatorial de dois fatores, nos níveis $a$ e $b$, é representada pela Tabela 2 .

Tabela 2 - Experimento fatorial de dois fatores - caso geral.

\begin{tabular}{|c|c|c|c|c|c|}
\hline \multirow[b]{3}{*}{ 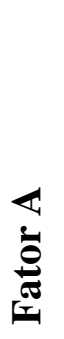 } & \multirow{2}{*}{ Níveis } & \multicolumn{4}{|c|}{ Fator B } \\
\hline & & 1 & 2 & $\ldots$ & $b$ \\
\hline & $\begin{array}{l}1 \\
2 \\
\ldots \\
a\end{array}$ & $\begin{array}{c}\mathrm{Y}_{111}, \mathrm{Y}_{112}, \ldots, \mathrm{Y}_{11 \mathrm{n}} \\
\mathrm{Y}_{211}, \mathrm{Y}_{212}, \ldots, \mathrm{Y}_{21 \mathrm{n}} \\
\ldots . \\
\mathrm{Y}_{\mathrm{a} 11}, \mathrm{Y}_{\mathrm{a} 12}, \ldots, \mathrm{Y}_{\mathrm{a} 1 \mathrm{n}}\end{array}$ & $\begin{array}{c}\mathrm{Y}_{121}, \mathrm{Y}_{122}, \ldots, \mathrm{Y}_{12 \mathrm{n}} \\
\mathrm{Y}_{221}, \mathrm{Y}_{222}, \ldots, \mathrm{Y}_{22 \mathrm{n}} \\
\ldots . \\
\mathrm{Y}_{\mathrm{a} 21}, \mathrm{Y}_{\mathrm{a} 22}, \ldots, \mathrm{Y}_{\mathrm{a} 2 \mathrm{n}}\end{array}$ & $\begin{array}{l}\cdots \\
\cdots \\
\cdots \\
\cdots\end{array}$ & $\begin{array}{c}\mathrm{Y}_{1 b 1}, \mathrm{Y}_{1 b 2}, \ldots, \mathrm{Y}_{1 b n} \\
\mathrm{Y}_{2 b 1}, \mathrm{Y}_{2 b 2}, \ldots, \mathrm{Y}_{2 b n} \\
\ldots . \\
\mathrm{Y}_{\mathrm{ab} 1}, \mathrm{Y}_{\mathrm{ab} 2}, \ldots, \mathrm{Y}_{\mathrm{abn}}\end{array}$ \\
\hline
\end{tabular}

Com o experimento organizado desta forma é possível verificar se: a resposta é alterada significativamente quando muda o nível do fator A; a resposta é alterada significativamente quando muda o nível do fator $\mathrm{B}$ e a interação dos fatores (coluna x linha) altera significativamente a resposta.

O modelo estatístico do planejamento fatorial é dado pela Equação 2:

$$
\mathrm{Y}_{\mathrm{ijk}}=\mu+\tau_{\mathrm{i}}+\beta_{\mathrm{i}}+(\tau \beta)_{\mathrm{ij}}+\varepsilon_{\mathrm{ijk}}
$$


sendo: $\mu$ é a média dos resultados;

$\tau_{\mathrm{i}}$ é o efeito principal do fator A

$\beta_{\mathrm{i}}$ é o efeito principal do fator B

$(\tau \beta)_{\mathrm{ij}}$ é o efeito da interação dos fatores A e B;

$\varepsilon_{\mathrm{ijk}}$ é o erro experimental

Um dos métodos que podem ser utilizados para determinar os coeficientes da equação é a Análise de Variância (ANOVA- do inglês Analysis of Variance), que também é utilizada para verificar a significância dos efeitos nas respostas (GALDÁMEZ, 2002).

\subsection{Planejamento fatorial $2^{\mathrm{k}}$}

Segundo Juran (1951), um experimento fatorial com k fatores, cada um deles com dois níveis é denominado experimento fatorial $2^{\mathrm{k}}$. O procedimento experimental desta técnica consiste em realizar testes com cada uma das combinações da matriz experimental, para em seguida, determinar e interpretar os efeitos principais e de interação dos fatores estudados e assim, poder identificar as melhores condições experimentais do processo. Para exemplificar este tipo de procedimento, considere-se um experimento com três fatores $\left(\mathrm{x}_{1}, \mathrm{x}_{2}\right.$ e $\left.\mathrm{x}_{3}\right)$, cada um destes fatores com dois níveis $(-1,+1)$. A matriz de planejamento para o experimento fatorial $2^{3}$ é apresentada na Tabela 3. A resposta para cada ensaio ou tratamento é descrita pela coluna Y, sendo que a ordem de realização do teste deve ser aleatória (GALDÁMEZ, 2002). 
Tabela 3 - Matriz de planejamento do experimento fatorial $2^{3}$.

\begin{tabular}{|c|c|c|c|c|c|}
\hline \multirow{2}{*}{ Testes } & \multicolumn{3}{|c|}{ Fatores } & \multirow{2}{*}{$\begin{array}{c}\text { Ordem do } \\
\text { teste }\end{array}$} & Resposta (Y) \\
\cline { 2 - 4 } & $\mathrm{X}_{1}$ & $\mathrm{X}_{2}$ & $\mathrm{X}_{3}$ & & \\
\hline 1 & -1 & -1 & -1 & 6 & $\mathrm{Y} 1$ \\
2 & +1 & -1 & -1 & 2 & $\mathrm{Y} 2$ \\
3 & -1 & +1 & -1 & 5 & $\mathrm{Y} 3$ \\
4 & +1 & +1 & -1 & 1 & $\mathrm{Y} 4$ \\
5 & -1 & -1 & +1 & 7 & $\mathrm{Y} 5$ \\
6 & +1 & -1 & +1 & 3 & $\mathrm{Y} 6$ \\
7 & -1 & +1 & +1 & 8 & $\mathrm{Y} 7$ \\
8 & +1 & +1 & +1 & 4 & $\mathrm{Y} 8$ \\
\hline
\end{tabular}

$\mathrm{Na}$ matriz genérica de planejamento, as colunas representam o conjunto de fatores investigados $\left(\mathrm{x}_{1}, \mathrm{x}_{2}\right.$ e $\left.\mathrm{x}_{3}\right)$, e as linhas representam os diferentes níveis ou as combinações dos fatores (níveis codificados: -1 (mínimo) e +1 (máximo)). A coluna $\mathrm{X}_{1}$ é definida pela combinação dos níveis $-1,+1,-1,+1,-1,+1,-1,+1, \ldots$, ou seja o sinal dessa coluna alterna em grupos de $2^{0}=1$. A coluna $\mathrm{X}_{2}$ é definida pela combinação dos níveis $-1,-1,+1,+1,-1,-1,+1$, $+1, \ldots$, ou seja, o sinal dessa coluna alterna em grupos de $2^{1}=2$. A coluna $\mathrm{X}_{3}$ é definida pela combinação dos níveis $-1,-1,-1,-1,+1,+1,+1,+1, \ldots$, ou seja o sinal dessa coluna alterna em grupos de $2^{2}=4$.

Devor, Chang e Sutherland (1992) definem que esta forma de organizar o experimento é chamada de ordem padrão (standard order). Esse arranjo garante que todas as colunas da matriz sejam ortogonais entre si. Com esse tipo de planejamento é possível determinar os efeitos principais e de interação que as variáveis independentes produzem nas respostas.

\subsection{Soja}

O Brasil é o segundo maior produtor mundial de soja (Glycine max L.), com uma produção de 96 milhões de toneladas do grão nas safras de 2014/2015. Segundo estimativa do $10^{\circ}$ levantamento da safra mundial de soja 2015/16, o grão apresentou um aumento de 1,5 milhão de toneladas em relação a janeiro de 2015. Com isso, o USDA prevê uma safra global recorde de 320,5 milhões de toneladas para o período 2015/16 (DEAGRO, 2016). 
O consumo mundial do grão foi estimado em 314,5 milhões de toneladas, volume relativamente estável em relação ao relatório de janeiro. Esse volume supera em 14,0 milhões de $\mathrm{t}$ a demanda de 2014/15 e representa um recorde. Em relação a janeiro de 2016, os estoques globais de oleaginosas foram ampliados em 1,1 milhão de toneladas, atingindo a maior marca, com 80,4 milhões de toneladas (DEAGRO, 2016).

Quanto às exportações mundiais, o Departamento de Agricultura dos EUA (USDA) manteve estável a previsão para exportações globais do grão, em 129,8 milhões de toneladas (DEAGRO, 2016). A Tabela 4 apresenta os valores estimados e a variação da produção de soja entre as safras de 2014/15 e 2015/16.

Tabela 4 - Produção mundial da soja (milhões de toneladas).

\begin{tabular}{|l|cc|c|}
\hline Países & \multicolumn{2}{|c|}{ Safras } & Variação \\
& $14 / 15$ & $15 / 16^{1}$ & $(\%)$ \\
\hline EUA & 106,9 & 107,0 & 0,1 \\
Brasil & 96,2 & 100,0 & 4,0 \\
Argentina & 61,4 & 58,5 & $-4,7$ \\
China & 12,2 & 12,0 & $-1,2$ \\
\hline
\end{tabular}

${ }^{1}$ Fevereiro de 2016

Em relação a janeiro de 2016, o USDA manteve sua previsão de oferta para os EUA e Brasil, estimadas em 107,0 e 100,0 milhões de toneladas, respectivamente, sendo a colheita recorde para ambos os países neste período. Para o Brasil, a previsão segundo a Conab seria de 100,9 milhões de toneladas no mesmo período (DEAGRO, 2016).

As estimativas para a produção da Argentina melhoraram em comparação a janeiro de 2016, passando de 57,0 para 58,5 milhões de toneladas. Tal fato se deve à previsão de uma área plantada recorde no país, equivalente a 20,0 milhões de hectares. Ainda assim, a colheita deverá ser 4,7\% inferior à safra 2014/15 (DEAGRO, 2016). A Tabela 5 apresenta os valores estimados e a variação do consumo de soja entre as safras de 2014/15 e 2015/16. 
Tabela 5 - Consumo mundial da soja (milhões de toneladas).

\begin{tabular}{|l|cc|c|}
\hline Países & \multicolumn{2}{|c|}{ Safras } & Variação \\
& $14 / 15$ & $15 / 16^{1}$ & $(\%)$ \\
\hline China & 87,2 & 94,2 & 8,0 \\
EUA & 54,9 & 54,7 & $-0,4$ \\
Argentina & 45,2 & 48,6 & 7,4 \\
Brasil & 42,9 & 43,0 & 0,2 \\
\hline
\end{tabular}

${ }^{1}$ Fevereiro de 2016

A China, maior consumidora de soja do mundo, ficou estável em relação a janeiro de 2016, projetado em 94,2 milhões de toneladas. Esse volume representa um recorde em termos históricos e incremento de 8\% em relação à 2014/15 (DEAGRO, 2016).

Mundialmente, a soja é um dos principais produtos da agricultura. É uma espécie amplamente usada devido a seus efeitos benéficos à saúde sobre várias doenças crônicas, incluindo a prevenção de câncer, doenças cardiovasculares (CHO et al., 2013). Além disso, a soja contém vários fitoquímicos, nomeados flavonoides, ácidos fenólicos, saponinas e triterpenoides (HUBERT et al., 2008; LEE; CHO, 2012; LEE et al., 2009). Dentre estes, os isoflavonoides e as antocianinas pertencem à classe dos flavonoides e são considerados os mais importantes grupos de compostos fenólicos solúveis devido às propriedades funcionais e nutricionais.

A soja é um dos grãos mais contaminados por agrotóxicos, segundo dados da Agência Nacional de Vigilância Sanitária (ANVISA), na última safra, que envolve o segundo semestre de 2010 e o primeiro semestre de 2011, o mercado nacional de agrotóxicos movimentou 936 mil toneladas de produtos, sendo 833 mil produzidas no país e 246 mil importadas (ANVISA/ UFPR, 2012). Em 2010, o mercado nacional movimentou cerca de 7,3 bilhões, representando 19\% do mercado global de agrotóxicos. Em 2011 houve um aumento de 16,3\% das vendas, sendo que as lavouras de soja, milho, algodão e cana-de-açúcar representam $80 \%$ do total das vendas do setor (SINDAG, 2012). Na safra de 2011, no Brasil foram plantados 71 milhões de hectares de lavoura, o que corresponde a cerca de 853 milhões de litros (produtos sintéticos) de agrotóxicos pulverizados, principalmente de herbicidas, fungicidas e inseticidas. Essa quantidade gera uma média e uso de 12 litros por hectare e exposição média ambiental de 4,5 litros de agrotóxicos por habitante (SINDAG, 2011; IBGE/SIDRA, 2012; ABRASCO, 2012).

De forma geral, pensamos na soja apenas como alimento, mas os grãos têm inúmeras outras finalidades, como para a alimentação animal, como parte da composição das rações e 
uso industrial como na produção de cosméticos, produtos farmacêuticos e de uso veterinário e principalmente como biocombustível.

O biocombustível de soja, reduz os impactos da poluição ambiental sobre a saúde humana e diminui a dependência do diesel importado, gerando emprego e renda para o Brasil. O biodiesel brasileiro produzido com soja reduz as emissões em $70 \%$ em relação ao diesel fóssil (UBRABIO, 2016)

A produção nacional de soja alcançou a marca de 96,2 milhões de toneladas, número registrado pelo MAPA na safra 2014-2015, período compreendido entre julho e setembro de 2015, em uma área de 32 milhões de hectares. Nas vendas externas, o mercado chinês permanece como o maior consumidor da commodity (produção bruta) brasileira. De janeiro a agosto de 2015 as exportações de soja em grãos totalizaram US\$ 17,71 bilhões, o equivalente a quase 46 milhões de toneladas. A safra anterior (2013-2014) havia sido pouco mais de 86 milhões de toneladas (PORTAL BRASIL, 2015).

\subsection{Sintomas da deficiência nutricional nas plantas}

Para um bom diagnóstico do estado nutricional das plantas, por deficiência ou por excesso, é imprescindível observar algumas informações para distinguir os sintomas nutricionais de outras possíveis causas, como a incidência de pragas ou doenças, distribuição de plantas nas lavouras, simetria de sintomas nas folhas, idade fisiológica, condições climáticas e desenvolvimento dos sintomas nas plantas. A folha da planta é um órgão que, de modo geral, reflete melhor o estado nutricional das plantas, ou seja, responde prontamente ao estresse causado pela falta de um nutriente ou elemento tóxico existente no solo (SFREDO, 2008).

Os nutrientes apresentam diferenças nas suas funções como constituintes metabólicos e estruturais dos órgãos vegetais. Isso determina uma variação no grau de transporte e redistribuição dos nutrientes, que ocorre predominantemente pelo floema, distinguindo-os em grupos de nutrientes móveis, de mobilidade alta $(\mathrm{N}, \mathrm{P}, \mathrm{K}, \mathrm{Mg}$ e $\mathrm{Cl})$; intermediária $(\mathrm{S}, \mathrm{Co}, \mathrm{Cu}$, Fe, Mn, Mo e Zn) e baixa (Ca e B) (SFREDO, 2008).

A maior ou menor mobilidade dos nutrientes no floema são importantes na identificação visual dos sintomas caraterísticos de alguma anormalidade, seja ela, deficiência ou toxicidade. A localização dos sintomas nas folhas ocorre em função da redistribuição dos nutrientes para os pontos de crescimento, estes dependentes de diversos fatores como o estágio de desenvolvimento das plantas e a velocidade de movimentação, entre outros. A localização das folhas com sintomas favorece a separação dos nutrientes pelos grupos de mobilidade e, deste 
modo, aumenta as chances de predizer quais os nutrientes causadores dos sintomas. Em todos os casos, é possível identificar um gradiente de intensidade dos sintomas mais comuns (SFREDO, 2008).

Trabalhos anteriores do nosso grupo de pesquisa confirmaram a presença de compostos fenólicos nas folhas, raízes e sementes da planta Canavalia ensiformis com propriedades alelopáticas, dentre eles a rutina (SANTOS, MORAES; REZENDE, 2007), ácido ferúlico, ácido clorogênico (MENDES; REZENDE, 2014) e naringenina (SANTOS, MORAES; REZENDE, 2007; MENDES; REZENDE, 2014), bem como a sua eficácia na inibição do desenvolvimento de plantas invasoras de folha larga. Assim, neste trabalho evidenciaram-se os compostos já definidos. 


\section{OBJETIVOS}

O objetivo geral desta pesquisa foi avaliar o potencial herbicida dos extratos aquosos obtidos das folhas de feijão-de-porco (Canavalia ensiformis) nas plantas invasoras falsa serralha (Emilia sonchifolia) e guanxuma (Sida spinosa), na cultura de soja, assim como os efeitos provocados no solo com a utilização destes extratos após sucessivas aplicações. Os objetivos específicos foram:

1. Plantação de sementes de feijão-de-porco para cultivo da planta e consequente produção das folhas;

2. Otimização de uma metodologia de extração assistida por micro-ondas para o preparo dos extratos aquosos a partir das folhas de feijão-de-porco;

3. Avaliação do potencial bioerbicida dos extratos aquosos obtidos das folhas de feijãode-porco (Canavalia ensiformis) por meio de extração assistida por micro-ondas;

4. Aplicação e avaliação dos extratos em plantações de soja convencional;

5. Avaliação dos efeitos alelopáticos dos extratos aquosos das folhas de feijão-de-porco sobre as plantas invasoras falsa serralha e guanxuma;

6. Avaliação dos efeitos provocados no solo com a utilização dos extratos aquosos de feijão-de-porco após sucessivas aplicações;

7. Validação da metodologia para identificação e quantificação de compostos fenólicos com caráter alelopático presentes nos extratos aquosos obtidos das folhas de feijão-deporco por HPLC-UV. 


\section{METODOLOGIA}

Todas as análises realizadas no Laboratório de Química Ambiental (LQA-IQSC-USP) do Instituto de Química da Universidade de São Paulo foram feitas com base nos requisitos da ISO 17025 e dos Princípios das Boas Práticas de Laboratório.

\subsection{Reagentes, soluções e demais materiais}

$\mathrm{O}$ material vegetal foi seco em estufa à $45^{\circ} \mathrm{C}$, triturado e peneirado antes de sua utilização. Foram utilizados os materiais de referência: ácido clorogênico, ácido ferúlico, naringenina e rutina obtidos da Sigma-Aldrich, cloreto de potássio, ácido acético glacial e metanol grau HPLC (PANREAC). Foram preparadas soluções estoque e de trabalho por diluição dos materiais de referência em metanol para análise cromatográfica.

\subsection{Local e culturas}

As sementes de feijão-de-porco foram cultivadas em caixas de madeira na área externa (LQA-IQSC-USP) (Figura 9). As sementes das plantas invasoras foram adquiridas da empresa Agrocosmos. As sementes de soja convencional (cultivar BRS283) foram cedidas pela EMBRAPA Soja, Londrina-PR e pela Fazenda Santa Inês, Ourinhos-SP. O material foi acondicionado em recipientes de plástico até sua utilização. As unidades experimentais foram vasos de $10 \mathrm{~L}$ de capacidade contendo em média de 7 a 8 plantas de soja e 4 a 5 plantas invasoras em cada vaso (Figura 10). O solo utilizado nos experimentos foi o argilo-siltoso marromavermelhado escuro, coletado próximo à Rodovia Luiz Augusto de Oliveira, cujas coordenadas são $48,876634^{\circ}$ longitude $22,276414^{\circ}$ latitude. O estudo foi realizado em casa de vegetação situada na cidade de São Carlos, campus 2 da Universidade de São Paulo, onde as temperaturas variaram de 20 a $38^{\circ} \mathrm{C}$. 
Figura 9 - Plantação do feijão-de-porco (Canavalia ensiformis).

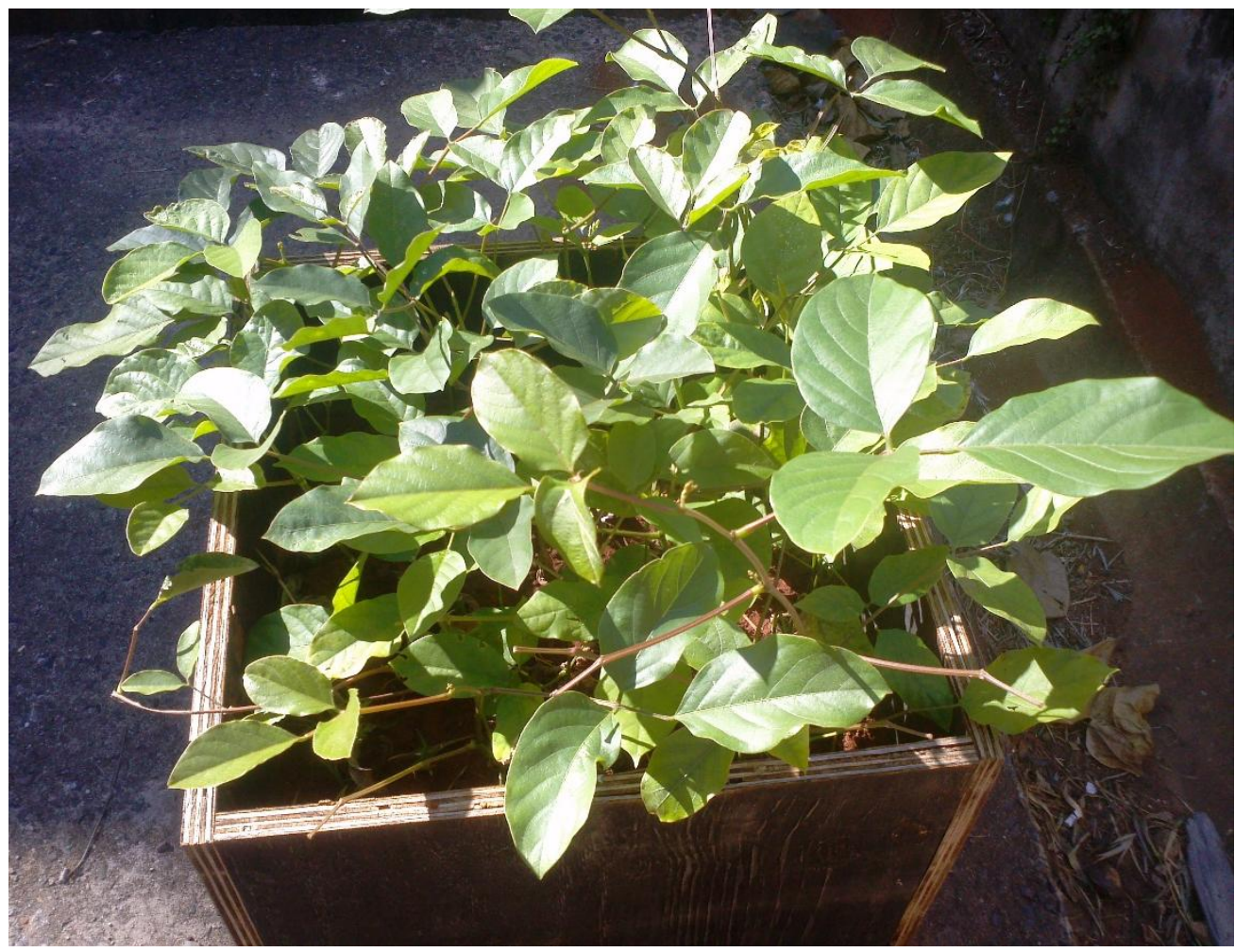

Fonte: Autoria própria.

Figura 10 - Distribuição dos vasos no experimento em casa de vegetação.

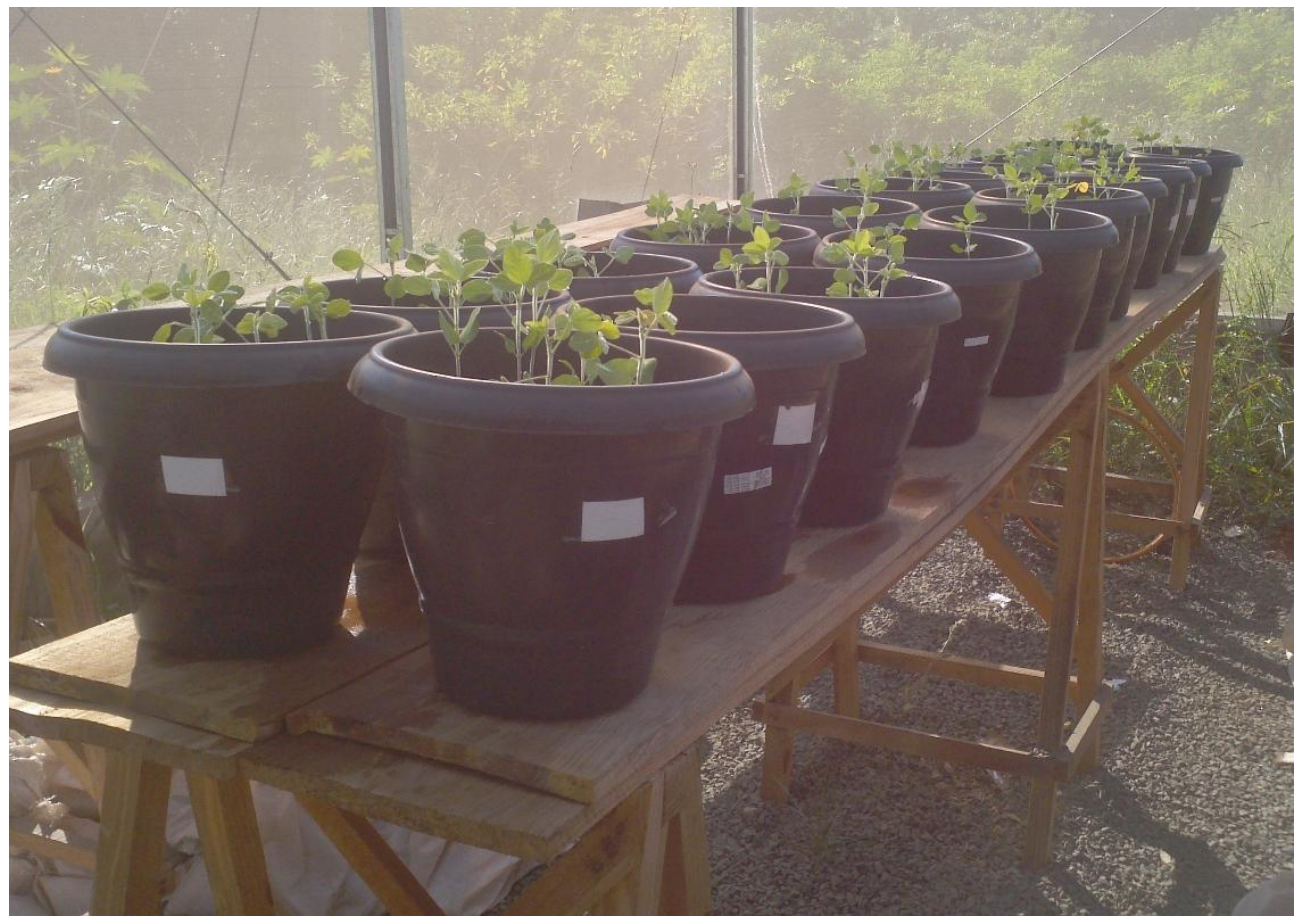

Fonte: Autoria própria. 


\subsection{Extração dos compostos fenólicos das folhas do feijão-de-porco}

\subsubsection{Extração assistida por micro-ondas}

O procedimento de extração dos compostos fenólicos (ácido clorogênico, ácido ferúlico, rutina e naringenina) foi realizado em um micro-ondas (SPEEDWAVE FOUR®, Microwave Digestion System with Built-in, Non- Contact, Temperature and Pressure Measurement, BERGHOF, Germany). Foram utilizados $2 \mathrm{~g}$ de material seco e peneirado em peneira de $2 \mathrm{~mm}$ de abertura de malha (para separar os talos e quaisquer outros resíduos sólidos) juntamente com $30 \mathrm{~mL}$ de água deionizada, em frascos de $60 \mathrm{~mL}$ de capacidade. Preparadas as misturas, cada frasco, foi devidamente lacrado e disposto no interior do equipamento e então aplicadas as seguintes condições: 20 min de irradiação a $60^{\circ} \mathrm{C}$ a $870 \mathrm{~W}(60 \%)$ de potência das micro-ondas; rampa de aquecimento até $70^{\circ} \mathrm{C}$, permanecendo durante 2 min sem irradiação; 20 min de irradiação a $80^{\circ} \mathrm{C}$ a $1015 \mathrm{~W}(70 \%)$ de potência das micro-ondas; rampa de aquecimento até $90^{\circ} \mathrm{C}$, permanecendo durante 2 min sem irradiação; 60 s de irradiação a $100^{\circ} \mathrm{C}$ a $1305 \mathrm{~W}(90 \%)$ de potência das micro-ondas.

Depois da etapa de extração, os frascos foram resfriados à temperatura ambiente antes de abertos, em seguida o material foi filtrado em filtro de $45 \mu \mathrm{m}$. Do material filtrado, uma alíquota de $1 \mathrm{~mL}$ foi tomada e diluída em $6 \mathrm{~mL}$ de metanol, para posterior análise cromatográfica.

Em condições otimizadas, a extração foi realizada em um tempo máximo de 10 min, com temperatura e potência fixa de $100^{\circ} \mathrm{C}$ e $60 \%(870 \mathrm{~W})$, respectivamente, utilizando-se a mesma massa de amostra.

\subsection{Análise cromatográfica via HPLC-UV}

Os compostos fenólicos foram analisados em um sistema HPLC-UV/Vis (LC-10AT Prominence, Shimadzu) equipado com detector UV/Vis (SPD-20A Prominence), desgaseificador (DGU-20A 5 Prominence). Uma coluna de fase reversa (XDB-C18 Agilent, 5 $\mu \mathrm{m}$ tamanho de partículas e $150 \mathrm{~mm}$ x 4,6 mm de diâmetro interno) foi usada para eluição dos compostos no modo isocrático. A fase móvel utilizada foi $2 \%$ ácido acético glacial em água + metanol (75:25, em volume), o software LabSolutions (Shimadzu) foi usado no controle do sistema e no processamento dos dados. 
Soluções estoque dos compostos fenólicos naringenina, ácido ferúlico, rutina e ácido clorogênico foram preparadas em metanol na concentração de $100 \mathrm{mg} \mathrm{L}^{-1}$. Soluções de trabalho foram preparadas pela diluição das soluções estoque em metanol e armazenadas à $(4 \pm 2){ }^{\circ} \mathrm{C}$. O volume de injeção foi de $20 \mu \mathrm{L}$, o comprimento de onda selecionado foi $282 \mathrm{~nm}$ para todos os compostos. Os compostos fenólicos foram identificados por comparação com o tempo de retenção e eluição com amostras padrão analisadas nas mesmas condições.

\subsection{Extração assistida por micro-ondas: preparo dos extratos aquosos contendo os compostos fenólicos com potencial bioerbicida}

O procedimento de extração para o preparo dos extratos aquosos foi realizado conforme descrito anteriormente, tendo algumas etapas adicionais após o término da MAE.

Assim, depois do procedimento de extração os frascos foram resfriados à temperatura ambiente antes de serem abertos, em seguida o material foi filtrado em papel de filtro de $45 \mu \mathrm{m}$ e concentrado em rotaevaporador $\left(80 \mathrm{rpm}\right.$ à $\left.80^{\circ} \mathrm{C}\right)$. A massa final foi pesada e utilizada no preparo dos extratos aquosos adicionando-se água deionizada, de forma a se obter as concentrações de 100, 125, 150 e $200 \mathrm{~g} \mathrm{~L}^{-1}$ para serem utilizadas para aplicação nos experimentos com as plantas invasoras. $\mathrm{O}$ pH do extrato foi de 5,8. Em trabalhos anteriores do nosso grupo de pesquisa, foram utilizados os extratos aquosos das sementes da Canavalia ensiformis na concentração de $50 \mathrm{~g} \mathrm{~L}^{-1}$.

Na Figura 11 estão todas as etapas para obtenção do bioerbicida utilizado, desde o cultivo do feijão-de-porco para obtenção das folhas até o extrato aquoso pronto para uso. 
Figura 11 - Etapas para o preparo dos extratos aquosos e obtenção do bioerbicida para aplicação.

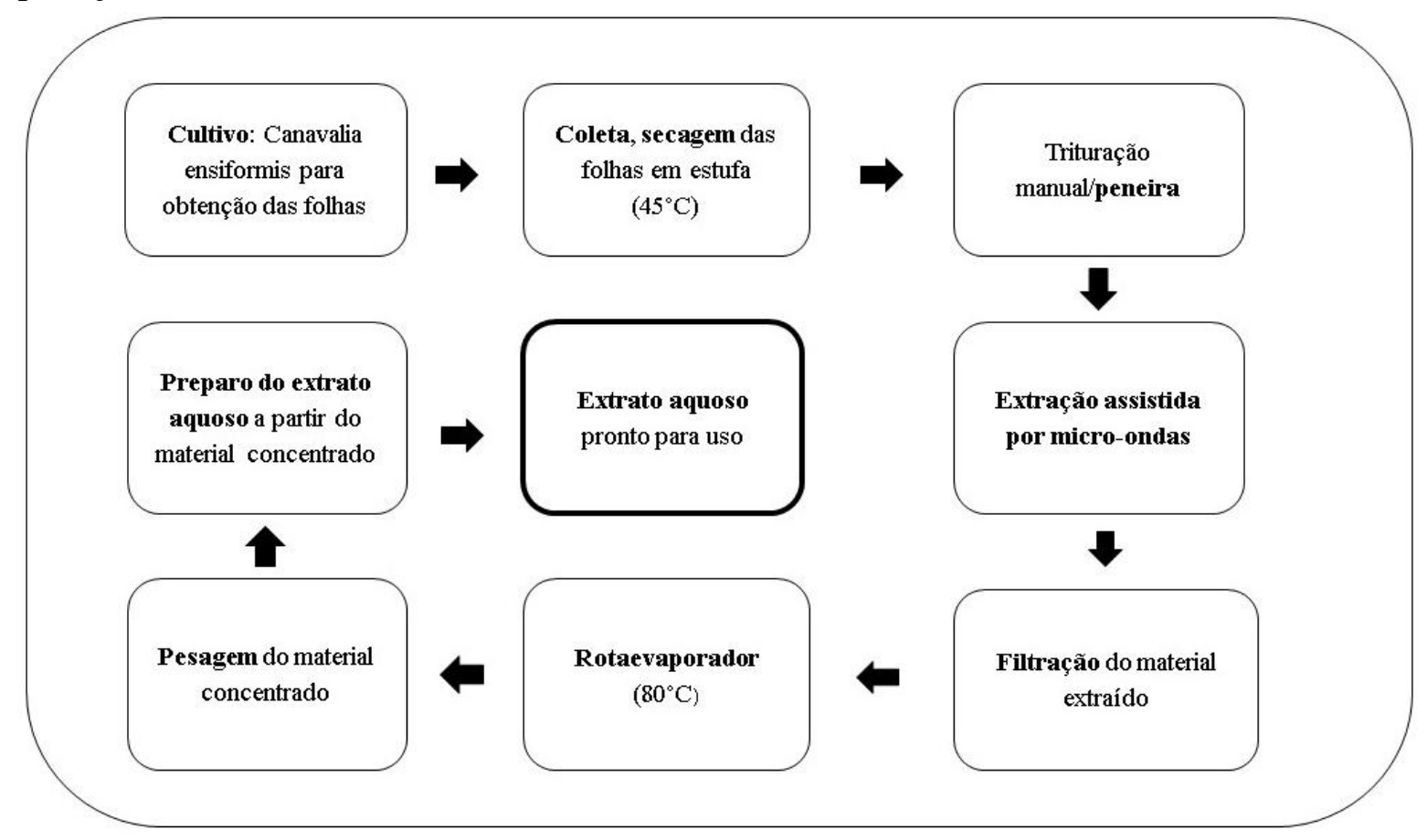

Fonte: Autoria própria.

\subsection{Ensaios em casa de vegetação: procedimento de aplicação dos extratos}

As aplicações foram realizadas em pós-emergência, considerando-se o fato que as plantas no sistema deveriam estar bem estabelecidas para analisarmos as injúrias causadas pela ação dos extratos e paralelamente avaliarmos as alterações no solo. As avaliações referentes às injúrias foram realizadas em ‘Dias Após Aplicação’ (DAA) dos extratos nas plantas invasoras, contados a partir da primeira aplicação.

Inicialmente, as aplicações foram feitas na planta invasora Emilia sonchifolia. Nesta etapa foram utilizados 16 vasos, sendo distribuídos em cinco triplicatas + um vaso referência (ao longo de todo o processo), correspondentes às etapas de avaliação e coleta do solo. As aplicações foram feitas por meio de um dispositivo que espalha o líquido como um spray de modo a atingir toda a área foliar da planta. O volume total de extrato aplicado variou de 1,5 a 3 $\mathrm{mL}$ por planta do bioerbicida na concentração de $200 \mathrm{~g} \mathrm{~L}^{-1} \mathrm{em}$ todos as plantas invasoras do experimento, sendo que a cada 15 dias, três vasos (uma triplicata) eram retirados para análise do solo e das injúrias causadas. Posteriormente, uma nova aplicação nos demais vasos do experimento era realizada, assim, pretendia-se avaliar a ação do bioerbicida após sucessivas 
aplicações e a possível acumulação deste no solo ao longo do experimento. Esse experimento teve uma duração máxima de 75 dias (última etapa de avaliação da ação dos extratos).

Com a planta invasora Sida spinosa foram utilizados um total de 16 vasos, distribuídos em quatro triplicatas + um vaso controle (referência) para cada triplicata. As aplicações foram realizadas da mesma forma descrita para a planta Emília sonchifolia conforme as etapas de avaliação e coleta do solo. Esse experimento teve uma duração máxima de 60 dias (última etapa de avaliação da ação dos extratos).

O início das aplicações dos tratamentos deu-se a partir do surgimento de pelo menos 4 a 7 folhas definitivas das plantas invasoras, aproximadamente 31 dias após o plantio das sementes, o qual chamou-se de tempo 0 (zero). A Tabela 6 descreve a metodologia de aplicação e avaliação da ação dos extratos sobre as plantas invasoras.

Tabela 6 - Metodologia de aplicação e avaliação dos efeitos visuais dos extratos contendo o potencial bioerbicida sobre as plantas invasoras, em intervalos iguais de 15 dias.

\begin{tabular}{|c|c|c|}
\hline Aplicações* & $\begin{array}{c}\text { Emilia sonchifolia } \\
\text { (DAA) }\end{array}$ & $\begin{array}{l}\text { Sida spinosa } \\
\text { (DAA) }\end{array}$ \\
\hline \multicolumn{3}{|l|}{$1^{\mathrm{a}}$} \\
\hline $1^{\mathrm{a}}, \mathbf{2}^{\mathbf{a}}$ & 15 (1ª avaliação) & $15^{\circ}\left(1^{\mathrm{a}}\right.$ avaliação $)$ \\
\hline $1^{\mathrm{a}}, 2^{\mathrm{a}}, \mathbf{3}^{\mathrm{a}}$ & 30 ( $2^{\mathrm{a}}$ avaliação) & $30^{\circ}\left(2^{\mathrm{a}}\right.$ avaliação $)$ \\
\hline $1^{\mathrm{a}}, 2^{\mathrm{a}}, 3^{\mathrm{a}}, 4^{\mathrm{a}}$ & 45 ( $3^{\mathrm{a}}$ avaliação) & $45^{\circ}\left(3^{\mathrm{a}}\right.$ avaliação $)$ \\
\hline \multirow[t]{2}{*}{$1^{\mathrm{a}}, 2^{\mathrm{a}}, 3^{\mathrm{a}}, 4^{\mathrm{a}}, \mathbf{5}^{\mathrm{a}}$} & 60 (4ª avaliação) & $60^{\circ}\left(4^{\mathrm{a}}\right.$ avaliação $)$ \\
\hline & 75 (5 a avaliação) & \\
\hline
\end{tabular}

*Números em negrito indicam o início das aplicações cumulativas.

Com base na Tabela 6 , a simbologia utilizada na apresentação dos resultados quanto às análises do solo foi: DAA15, DAA30, DAA45, DAA60 ou DAA75, referentes aos dias em que o solo foi coletado em casa de vegetação e levado ao laboratório para análise. As análises do solo foram realizadas paralelamente às analise das injúrias causadas nas plantas invasoras, de modo a se verificar possíveis alterações na composição do solo causadas pelo contato com o bioerbicida.

\subsection{Análise química do solo}

O solo coletado no campo antes do início dos experimentos em casa de vegetação foi seco a temperatura ambiente, limpo manualmente para retirar restos de raízes e plantas e passado em peneira de $2 \mathrm{~mm}$ de abertura de malha para homogeneizar o material e obter uma 
fração de terra fina seca ao ar (TFSA) (EMBRAPA, 1997) para então ser caracterizado e utilizado nos experimentos em casa de vegetação. As análises do solo após o início dos experimentos em casa de vegetação também foram realizadas em dias após a aplicação do bioerbicida, de modo a se comparar o comportamento do solo entre os períodos definidos para aplicação $\left(0,15,30,45\right.$ e $60^{\circ}$ dia, totalizando 5 aplicações $)$.

Para uma maior representatividade, as amostras do solo foram coletadas diretamente das unidades experimentais, sendo coletadas um conjunto de amostras simples, retiradas de pontos aleatórios e de aproximadamente $20 \mathrm{~cm}$ de profundidade, de modo a constituir uma amostra composta de aproximadamente $500 \mathrm{~g}$. A Figura 12 apresenta o esquema de todas as etapas do experimento em casa de vegetação, desde a primeira aplicação dos extratos até as avaliações das injúrias e a coleta do solo para a análise.

Figura 12 - Etapas do experimento em casa de vegetação.

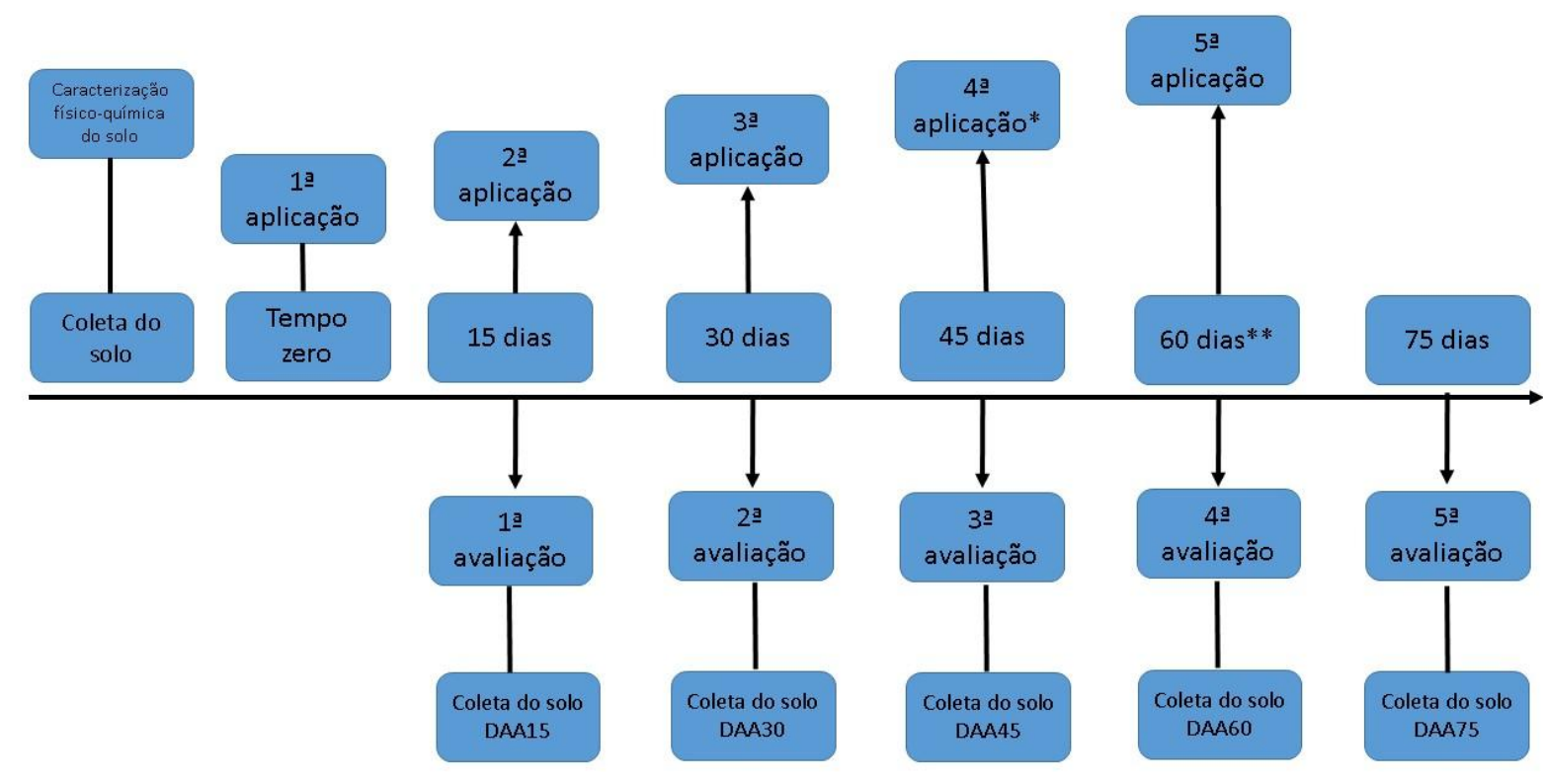

* Última aplicação na planta invasora Sida spinosa.

**Fim do experimento com a planta invasora Sida spinosa (última avaliação).

\subsubsection{Determinação de pH}

Pesaram-se $10 \mathrm{~g}$ de amostra seca e em seguida adicionaram-se $25 \mathrm{~mL}$ de solução de $\mathrm{CaCl}_{2}$, $0,01 \mathrm{~mol} \mathrm{~L}^{-1}$. A mistura foi agitada manualmente e mantida em repouso por aproximadamente $1 \mathrm{~h}$ até a leitura em pHmetro (Ion PHB 500) (EMBRAPA, 1997). 


\subsubsection{Determinação de cálcio e potássio}

A 12,5 g de amostra adicionaram-se $125 \mathrm{~mL}$ de solução de acetato de amônio a pH 7. Agitou-se a mistura com movimentos circulares várias vezes durante o dia. Após a última agitação deixou-se a solução em repouso por $16 \mathrm{~h}$. No dia seguinte filtrou-se a mistura. A determinação do cálcio foi feita em espectrofotômetro de absorção atômica e o potássio em fotômetro de chama (EMBRAPA, 1997).

\subsubsection{Determinação de fósforo disponível}

Cinco gramas da amostra de solo foram pesados e transferidos para um Erlenmeyer de $125 \mathrm{~mL}$, em seguida adicionaram-se $50 \mathrm{~mL}$ de solução ácida diluída de $\mathrm{H}_{2} \mathrm{SO}_{4}$ 0,0125 mol L ${ }^{-1}$ + $\mathrm{HCl}$ 0,05 mol L ${ }^{-1}$ (Mehlich-1). Agitou-se por $30 \mathrm{~min}$ em agitador horizontal e deixou-se em repouso por $16 \mathrm{~h}$. No dia seguinte filtrou-se a mistura em papel de filtro comum. A determinação do fósforo disponível na amostra foi feita com solução ácida de molibdato de amônio diluída e ácido ascórbico 3\% em espectrofotômetro (HACH- DR6000 UV/Vis), a 660 nm (EMBRAPA, 1997).

\subsubsection{Determinação de Nitrogênio Kjeldahl Total- NKT}

O NKT foi extraído em um sistema de digestão por micro-ondas. Nesta metodologia, pesou-se 0,250 g de amostra e transferiu-se esta massa para frascos de $60 \mathrm{~mL}$ de capacidade, próprios do equipamento, em seguida adicionaram-se $7 \mathrm{~mL}$ de ácido sulfúrico $\left(\mathrm{H}_{2} \mathrm{SO}_{4}\right)$ p.a. +2 $\mathrm{mL}$ de peróxido de hidrogênio $\left(\mathrm{H}_{2} \mathrm{O}_{2}\right)$ concentrado, esperou-se aproximadamente 20 min antes de lacrar os frascos. No equipamento as amostras foram sujeitas à metodologia (programação) adequada para digestão de solo (Tabela 7). Após a etapa de digestão os frascos foram resfriados a temperatura ambiente antes de serem abertos. Depois de resfriados, adicionou-se água lentamente para posterior filtração em balão volumétrico de $100 \mathrm{~mL}$. A determinação do NKT foi feita em um espectrofotômetro UV $(\mathrm{HACH})$, segundo metodologia do aparelho (Método Nessler). 
Tabela 7 - Programação utilizada para digestão de amostras de solo para análise de nitrogênio Kjeldahl total (NKT)

\begin{tabular}{cccccc}
\hline Etapa & $\begin{array}{c}\text { Temperatura } \\
\left(\mathrm{C}^{\circ}\right)\end{array}$ & $\begin{array}{c}\text { Pressão } \\
(\mathrm{bar})\end{array}$ & $\begin{array}{c}\text { Rampa } \\
(\min )\end{array}$ & $\begin{array}{c}\text { Tempo } \\
(\mathrm{min})\end{array}$ & $\begin{array}{c}\text { Potência } \\
(\%)\end{array}$ \\
\hline 1 & 150 & 40 & 5 & 10 & 70 \\
2 & 160 & 40 & 2 & 10 & 80 \\
3 & 180 & 40 & 2 & 20 & 90 \\
4 & 210 & 40 & 2 & 5 & 90 \\
\hline
\end{tabular}

\subsubsection{Método Nessler}

Pipetou-se $1 \mathrm{~mL}$ da amostra filtrada para uma proveta de $25 \mathrm{~mL}$, em seguida adicionouse: 1 gota do indicador TKN (Total Kjeldahl Nitrogen); solução saturada de KOH gota a gota, até a solução tornar-se azul; completou-se o volume da proveta para $20 \mathrm{~mL}$; em seguida, adicionou-se 3 gotas de estabilizador mineral e agitar a solução na proveta; acrescentou-se 3 gotas de álcool polivinílico e agitar; completou-se o volume da proveta para $25 \mathrm{~mL}$; em seguida adicionou-se $1 \mathrm{~mL}$ de reagente de Nessler (agitar) e aguardou-se $1 \mathrm{~min}$ antes da leitura no espectrofotômetro. Pela Equação 3 determinou-se a concentração de nitrogênio.

$$
\mathrm{TKN}=\frac{75 \times A}{B \times C}
$$

sendo: $\mathrm{A}=$ é leitura em $\mathrm{mg} \mathrm{L}^{-1}$ obtida no espectrofotômetro

$\mathrm{B}=$ volume em $\mathrm{mL}$ tomado da digestão

$\mathrm{C}=$ volume de análise em $\mathrm{mL}$ tomados da amostra digerida

\subsubsection{Determinação da acidez trocável}

Cinco gramas de amostra de solo foram pesados e transferidos para um Erlenmeyer de $125 \mathrm{~mL}$ e adicionados $50 \mathrm{~mL}$ de $\mathrm{KCl} 1 \mathrm{~mol} \mathrm{~L}^{-1}$. Agitou-se manualmente algumas vezes e deixou-se em repouso durante 30 minutos. Filtrou-se em papel de filtro adicionando-se duas 
porções de $10 \mathrm{~mL}$ de $\mathrm{KCl}$. Adicionou-se ao filtrado 6 gotas de fenolftaleína a $0,1 \% \mathrm{~m} / \mathrm{v}$ e titulou-se com $\mathrm{NaOH}$ 0,01 mol L $\mathrm{L}^{-1}$. Pela equação a seguir, determinou-se a acidez trocável (EMBRAPA, 1997).

$$
\text { Acidez trocável }\left(\mathrm{cmol}_{\mathrm{d}} / \mathrm{kg}\right)=(\mathrm{V} \times \mathrm{C} \times 100) / \mathrm{m}
$$

sendo: $\mathrm{V}=$ volume $(\mathrm{mL})$ de $\mathrm{NaOH}$ gastos na titulação

$$
\begin{aligned}
& \mathrm{C}=\text { concentração }\left(\mathrm{mol} \mathrm{L}^{-1}\right) \text { de } \mathrm{NaOH} \\
& \mathrm{m}=\text { massa }(\mathrm{g}) \text { da amostra. }
\end{aligned}
$$

\subsubsection{Determinação da capacidade de troca catiônica (CTC)}

Dois gramas de amostra foram transferidos para um Erlenmeyer de $250 \mathrm{~mL}$ e adicionado $1 \mathrm{~g}$ de carvão ativo e, em seguida, $100 \mathrm{~mL}$ de $\mathrm{HCl}\left(0,5 \mathrm{~mol} \mathrm{~L}^{-1}\right)$. A mistura foi agitada por aproximadamente $30 \mathrm{~min}$, filtrada a vácuo, lavando o filtro com água e em seguida com 2 porções de $50 \mathrm{~mL}$ de solução de acetato de cálcio, completando o volume com água até atingir $250 \mathrm{~mL}$ e titulando com $\mathrm{NaOH} 0,1 \mathrm{~mol} \mathrm{~L}^{-1}$ adicionando-se 6 gotas de fenolftaleína a $0,1 \%$ como indicador. A capacidade de troca catiônica do solo foi calculada pela Equação 5 (EMBRAPA, 1997):

$$
\text { CTC }\left(\mathrm{mmol}_{\mathrm{c}} \mathrm{kg}^{-1}\right)=(\mathrm{Va}-\mathrm{Vb}) \mathrm{x}[\mathrm{NaOH}] / \mathrm{m}
$$

sendo: $\quad \mathrm{Va}=$ volume $(\mathrm{mL})$ de $\mathrm{NaOH}$ gasto na titulação da amostra

$\mathrm{Vb}=$ volume $(\mathrm{mL})$ de $\mathrm{NaOH}$ gasto na titulação do branco

$[\mathrm{NaOH}]=$ concentração $\left(\mathrm{mol} \mathrm{L}^{-1}\right)$ da solução de $\mathrm{NaOH}$

$\mathrm{m}=\operatorname{massa}(\mathrm{g})$ da amostra.

\subsubsection{Determinação de carbono orgânico total (Total Organic Carbon-TOC)}

Foram pesados aproximadamente $100 \mathrm{mg}$ da amostra de solo, previamente seca em estufa à $45^{\circ} \mathrm{C}$ e peneirada em peneira de $2 \mathrm{~mm}$ de abertura de malha. As determinações de 
carbono total foram feitas em um aparelho TOC- VCPH (Shimadzu), acoplado a um módulo para amostras sólidas SSM-5000A (Shimadzu), com detector de combustão para que a porcentagem de carbono total fosse determinada. O teor de matéria orgânica do solo foi estimado, multiplicando-se o valor obtido de carbono orgânico pelo fator de Waksman 1,724 (EMBRAPA, 1997).

\subsection{Análise granulométrica do solo}

A análise granulométrica do solo foi realizada para se determinar a porcentagem de argila, silte, areia e pedregulho presentes no solo a fim de caracterizá-lo e classificá-lo. Inicialmente, à amostra de solo seca em estufa $(20 \mathrm{~g})$ foram adicionados $100 \mathrm{~mL}$ de uma solução dispersante de hexametafosfato de sódio (45,7 g em 1 litro de água destilada) mantendo agitação constante até ocorrer a dissolução completa do reagente. Em seguida, a amostra com a solução dispersante foi agitada por 16 horas. Após a etapa de agitação, a suspensão foi passada por uma peneira de $0,05 \mathrm{~mm}$ de malha. $\mathrm{O}$ material retido pela peneira foi lavado e posteriormente seco em estufa a $100^{\circ} \mathrm{C}$ até massa constante. $\mathrm{O}$ material filtrado foi transferido para uma proveta de $1000 \mathrm{~mL}$ cujo volume foi completado com água destilada.

Em seguida, foram determinadas as porcentagens de silte e argila. Para isso, a mistura presente na proveta foi agitada até a completa suspensão das partículas, inserindo-se um densímetro na proveta e anotando-se o início da sedimentação. As medidas de temperatura e densidade foram feitas nos tempos de 0,$5 ; 1 ; 2 ; 4 ; 8 ; 15 ; 30 ; 60 ; 120 ; 240$ e 480 minutos. Com os dados obtidos foram calculados o diâmetro máximo de partícula e o percentual de particulados na suspensão, conforme a Associação Brasileira de Normas Técnicas - ABNT (NBR 7181, 1984).

Posteriormente, as análises de areia e pedregulho foram realizadas. As frações de pedregulhos e areias fina, média e grossa foram determinadas pelo método de peneiramento. Neste método, o material retido pela peneira $0,05 \mathrm{~mm}$ de malha, já seco, é novamente peneirado através de uma série de peneiras com malhas de: 4,8; 9,5; 19,0; 25,0;38,0 e 50,0 mm. Para auxiliar no peneiramento, o sistema foi colocado em uma mesa agitadora durante 10 minutos. A massa retida em cada peneira foi anotada e os percentuais da composição do solo calculados (NBR 6457, 1986). 


\subsection{Tratamentos dos dados}

Os dados referentes aos possíveis efeitos causados pela ação do bioerbicida no solo, dentro dos intervalos de coleta, foram avaliados por meio da análise de variância (ANOVA) e a diferença da significância entre as médias foi determinada pelo teste de Tukey $(P<0,05)$, usando o software Origin pro 8 (v.80724-B724).

\subsection{Gestão de resíduos}

Os resíduos gerados neste trabalho foram encaminhados ao Laboratório de Resíduos Químicos (LRQ) para tratamento adequado.

Um dos aspectos importantes é a eliminação adequada de resíduos químicos gerados, de forma a evitar o descarte inadequado direto ao meio ambiente. Armazenar os resíduos em recipientes adequados para posteriormente encaminhar para o Laboratório de Resíduos Químicos - LRQ do campus 1 da USP de São Carlos foi a estratégia tomada neste trabalho (CAVALHEIRO, 2010).

A aplicação das boas práticas de laboratório associadas à conscientização quanto a prevenção da poluição ambiental é de grande importância na gestão correta de resíduos. Para o correto armazenamento e descarte dos resíduos gerados durante o desenvolvimento deste trabalho foram seguidos os procedimentos a seguir:

- Identificação da categoria à qual pertencem os resíduos que se pretendia eliminar;

- Armazenamento dos resíduos em recipientes apropriados de pequeno volume;

- Todos os frascos contendo resíduos foram devidamente etiquetados (data de início do armazenamento, conteúdo e laboratório) e preenchidos juntamente com o Diagrama de Perigo.

- Os resíduos químicos (sólidos ou líquidos), que devido a sua reatividade e toxicidade não podem ser eliminados como os solventes devem ser separados dos outros produtos incompatíveis e armazenados até a sua eliminação.

Das substâncias que puderam ser descartadas diretamente na pia foram obedecidas algumas regras, como, apenas compostos solúveis em água ou após diluição; compostos com características ácidas ou básicas foram neutralizados antes do descarte. 
Dos materiais que foram descartados no lixo comum podem-se citar, luvas, papéis de filtro e outros descartáveis. Materiais de vidro (frascos, ampolas etc) que continham produtos químicos foram descartados no lixo de recicláveis. 


\section{RESULTADOS E DISCUSSÕES}

\subsection{Extração assistida por micro-ondas: testes iniciais de extração}

Inicialmente foram avaliadas metodologias de extração variando as condições de aquecimento de 50 a $85^{\circ} \mathrm{C}$, utilizando-se $40 \%(580 \mathrm{~W})$ da potência do equipamento. Demais testes foram realizados ajustando-se a potência (50\%) e variando a temperatura até o máximo de $90^{\circ} \mathrm{C}$.

\subsubsection{Influência do tempo, potência e temperatura na extração}

No campo da extração por micro-ondas a seleção do tempo é importante devido a possíveis degradações térmicas dos compostos alvo. Assim, o melhor caminho para selecionar o melhor tempo de extração é empiricamente definir o rendimento pelo tempo. Geralmente, altas temperaturas são melhores para extração devido ao aumento de solubilidade, mas por outro lado, altas temperaturas promovem a destruição da parede celular, o que resulta em mais compostos liberados pela planta (ZHANG et al., 2013).

Neste estudo foram testados os tempos de 2, 5, 8, 10, 20 e 30 minutos, tendo como referência o composto ácido ferúlico. De acordo com os testes cromatográficos, os tempos de 2, 5, 8 e 10 min não foram capazes de extrair os compostos de interesse, provavelmente pela baixa potência utilizada nos testes (40\%). Já o tempo de $30 \mathrm{~min}$ promoveu uma ligeira degradação dos compostos extraídos, resultando em um sinal cromatográfico menor do composto de referência.

A influência da potência na extração dos compostos fenólicos foi examinada variandose as energias das micro-ondas de 60 a 90\%, mantendo-se as condições de aquecimento (60$100^{\circ} \mathrm{C}$ ). O aumento gradativo da potência favoreceu o processo de extração. Logo, o tempo escolhido para extração foi 20 min, realizando-se dois ciclos de extrações (etapas 1 e 3 na Tabela 8 ), utilizando-se temperatura final de $100^{\circ} \mathrm{C}$ e potência máxima de $90 \%(1305 \mathrm{~W})$. 
Tabela 8 - Programação da extração assistida via micro-ondas dos compostos fenólicos nas folhas da Canavalia ensiformis.

\begin{tabular}{cccccc}
\hline Etapa & $\begin{array}{c}\text { Temperatura } \\
\left(\mathrm{C}^{\circ}\right)\end{array}$ & $\begin{array}{c}\text { Pressão } \\
(\text { bar })\end{array}$ & $\begin{array}{c}\text { Rampa } \\
(\min )\end{array}$ & $\begin{array}{c}\text { Tempo } \\
(\mathrm{min})\end{array}$ & $\begin{array}{c}\text { Potência } \\
(\%)\end{array}$ \\
\hline 1 & 60 & 35 & 2 & 20 & 60 \\
2 & -- & 0 & 2 & 2 & 0 \\
3 & 80 & 35 & 2 & 20 & 70 \\
4 & -- & 0 & 2 & 2 & 0 \\
5 & 100 & 35 & 2 & 1 & 90 \\
\hline
\end{tabular}

Definida a faixa de temperatura $\left(60-100^{\circ}\right)$, adaptou-se a programação do equipamento em ciclo, de modo que entre cada etapa de extração fossem realizadas pausas de 2 min sem irradiação para evitar superaquecimento e, consequentemente, evitar uma possível degradação química dos compostos fenólicos.

O princípio do aquecimento usando energias micro-ondas é baseado no efeito direto das micro-ondas nas moléculas por condução iônica e rotação dipolo. Moléculas polares tais como os polifenóis absorvem fortemente energias micro-ondas por causa do seu permanente momento de dipolo, o que resulta em um rápido aumento da temperatura e consequentemente o término da extração (PROESTOS; KOMAITIS, 2008).

\subsubsection{Extração assistida por micro-ondas: otimização da metodologia}

Existem muitos fatores que afetam a eficiência da extração assistida por micro-ondas. Alguns destes são a potência, a temperatura, o tempo de extração, o tipo de solvente e a razão entre os solventes. Neste trabalho, utilizou-se apenas água como solvente.

Antes da otimização da extração, experimentos preliminares foram realizados para avaliar o comportamento da potência, da rampa e do tempo de extração de acordo com as limitações na programação do equipamento. A potência mínima capaz de atingir a temperatura máxima programada foi de $60 \%$, assim, ajustes maiores, acima deste valor não afetariam a temperatura programada, já que com esta potência o equipamento alcançaria a temperatura de $100^{\circ} \mathrm{C}$. Com base nisso, os primeiros experimentos foram realizados e os resultados obtidos da extração seguida da determinação cromatográfica mostraram altos desvios-padrão, o que 
inviabilizou a sequência da metodologia de otimização. Avaliando-se as possíveis causas do erro, desde a manipulação das amostras até a operação dos equipamentos, chegou-se à conclusão que as condições cromatográficas afetaram as determinações, especificamente a fase móvel utilizada (2\% de ácido acético glacial em água + metanol; 75:25 em volume), cuja composição provavelmente sofreu variação no decorrer dos dois dias de análise. Assim, novos ensaios foram realizados tendo o cuidado de acondicionar a fase móvel e realizar todos os ensaios no mesmo dia.

No estudo de otimização foi utilizado um planejamento fatorial do tipo $2^{3}$ compreendendo 16 experimentos em duplicata, executados de forma aleatória. Os fatores avaliados foram a temperatura, a rampa (tempo necessário para o equipamento alcançar a temperatura máxima programada) e o tempo de extração, utilizando apenas água como solvente nas extrações. A variável resposta escolhida foi a área do pico cromatográfico para o composto ácido ferúlico. O modelo linear da interação dos fatores foi ajustado para os dados experimentais (Equação 6), onde $\hat{y}$ é o valor predito (o rendimento do composto extraído, ácido ferúlico), $\beta$ são os coeficientes do modelo, e $x_{1}, x_{2}, x_{3}$ os fatores codificados. O software Origin 8.0 foi utilizado para análise dos dados experimentais.

$$
\hat{y}=\beta_{0}+\beta_{1} x_{1}+\beta_{2} x_{2}+\beta_{3} x_{3}+\beta_{12} x_{1} x_{2}+\beta_{13} x_{1} x_{3}+\beta_{23} x_{2} x_{3}
$$

Os valores codificados e decodificados das variáveis independentes (temperatura, tempo e rampa) para cada experimento, assim como da variável dependente (resposta, área e concentração em $\mathrm{mg} \mathrm{g}^{-1}$ ) do planejamento fatorial estão dispostos na Tabela 9. 
Tabela 9 - Planejamento fatorial $2^{3-0}$, variável-resposta: área e $\mathrm{mg} \mathrm{g}^{-1}$.

\section{Fatores}

(1) Temperatura

$\left({ }^{\circ} \mathrm{C}\right)$
(2) Tempo

(min)
(3) Rampa (min)

Concentração

$\left(\mathrm{mg} \mathrm{g}^{-1}\right)$ em $2 \mathrm{~g}$ de

Area* material seco*

\begin{tabular}{lllll}
\hline $60(-1)$ & $10(-1)$ & $2(-1)$ & 12675 & 14,56 \\
$60(-1)$ & $10(-1)$ & $5(+1)$ & 34452 & 51,90 \\
$60(-1)$ & $40(+1)$ & $2(-1)$ & 23187 & 39,51 \\
$60(-1)$ & $40(+1)$ & $5(+1)$ & 42233 & 60,48 \\
$100(+1)$ & $10(-1)$ & $2(-1)$ & 63685 & 84,10 \\
$100(+1)$ & $10(-1)$ & $5(+1)$ & 85619 & 108,25 \\
$100(+1)$ & $40(+1)$ & $2(-1)$ & 31969 & 49,17 \\
$100(+1)$ & $40(+1)$ & $5(+1)$ & 46387 & 65,03 \\
\hline
\end{tabular}

* Valores médios (duplicata).

\subsubsection{Estimativa do modelo}

$\mathrm{O}$ ajuste do modelo é verificado pelo coeficiente de determinação $\left(\mathrm{R}^{2}\right)$. O modelo polinomial foi ajustado aos dados experimentais (Equação 7) com $R^{2}=0,9992\left(R^{2}\right.$ adj $\left.=0,9987\right)$. Pela análise de variância (Tabela 10 ), os valores de $F$ e $p$ mostram a significância entre os dados.

$$
\hat{y}=42.526+14.389 x_{1}-6.582 x_{2}+9.647 x_{3}-11.155 x_{1} x_{2}-559 x_{1} x_{3}-1.281 x_{2} x_{3}
$$

Onde: $\quad x_{1}=\frac{\text { temperatura-80 }}{20} ; x_{2}=\frac{\text { tempo-25 }}{15} ;$ e $x_{3}=\frac{\text { rampa-3,5 }}{1,5}$ 
Tabela 10 - Análise de variância (ANOVA) dos resultados experimentais.

\begin{tabular}{lccccc}
\hline Parâmetros & $\begin{array}{c}\text { Soma dos } \\
\text { quadrados }\end{array}$ & Graus de liberdade & $\begin{array}{c}\text { Média dos } \\
\text { quadrados }\end{array}$ & Teste $F$ & Valor de $p$ \\
\hline Modelo & $5,99697 \mathrm{E} 9$ & 3 & $1,99893 \mathrm{E} 9$ & 15,71661 & 0,00019 \\
$\mathrm{X}_{1}$ & $3,3127 \mathrm{E} 9$ & 1 & $3,31272 \mathrm{E} 9$ & 11,01541 & 0,00507 \\
$\mathrm{X}_{2}$ & $6,93098 \mathrm{E} 8$ & 1 & $6,93098 \mathrm{E} 8$ & 1,42072 & 0,25310 \\
$\mathrm{X}_{3}$ & $1,48898 \mathrm{E} 9$ & 1 & $1,48898 \mathrm{E} 9$ & 3,45468 & 0,08422 \\
$\mathrm{X}_{1} \mathrm{X}_{2}$ & $1,99097 \mathrm{E} 9$ & 1 & $1,99097 \mathrm{E} 9$ & 15,65401 & 0,00191 \\
$\mathrm{X}_{1} \mathrm{X}_{3}$ & $4,99634 \mathrm{E} 6$ & 1 & $4,99634 \mathrm{E} 6$ & 0,02207 & 0,88436 \\
$\mathrm{X}_{2} \mathrm{X}_{3}$ & $2,62477 \mathrm{E} 7$ & 1 & $2,62477 \mathrm{E} 7$ & 0,05926 & 0,81177 \\
Erro & $1,52623 \mathrm{E} 9$ & 12 & $1,27186 \mathrm{E} 8$ & & \\
Cor. total & $7,52302 \mathrm{E} 9$ & 15 & & & \\
& $\mathrm{R}^{2}=0,9992$ & $\mathrm{R}^{2}$ ajustado $=0,9987$ & & & \\
\hline $\mathrm{X}_{1}=$ temperatura da extração, $\mathrm{X}_{2}=$ tempo de irradiação e $\mathrm{X}_{3}=$ rampa de tempo. &
\end{tabular}

Pelo resultado da análise de variância do ajuste linear do modelo, temos que valores mais altos de $F$ associados a valores baixos de $p(<0,05)$ demonstram que o modelo gerado é estatisticamente significativo (KARABEGOVIC et al., 2013).

Valores de $p$ são usados para confirmar a significância de cada coeficiente, ou seja, o menor valor de $p$ está no maior efeito (ZHAO et al., 2011). De acordo com os valores de $F$ e $p$ (Tabela 10), o fator com o maior efeito está na temperatura $\left(X_{1}\right)$, seguido da rampa $\left(X_{3}\right)$; entretanto esta análise indica que apenas a interação: temperatura $\mathrm{x}$ tempo $\left(\mathrm{X}_{1} \mathrm{X}_{2}\right)$ foi significativa.

De acordo com a Figura 13, que apresenta o cubo das respostas obtidas (área do pico referente ao composto ácido ferúlico), o aumento do rendimento da extração é melhorado pelo aumento da temperatura de extração e pela rampa e pela diminuição do tempo de extração. 
Figura 13 - Cubo de respostas (valores médios)

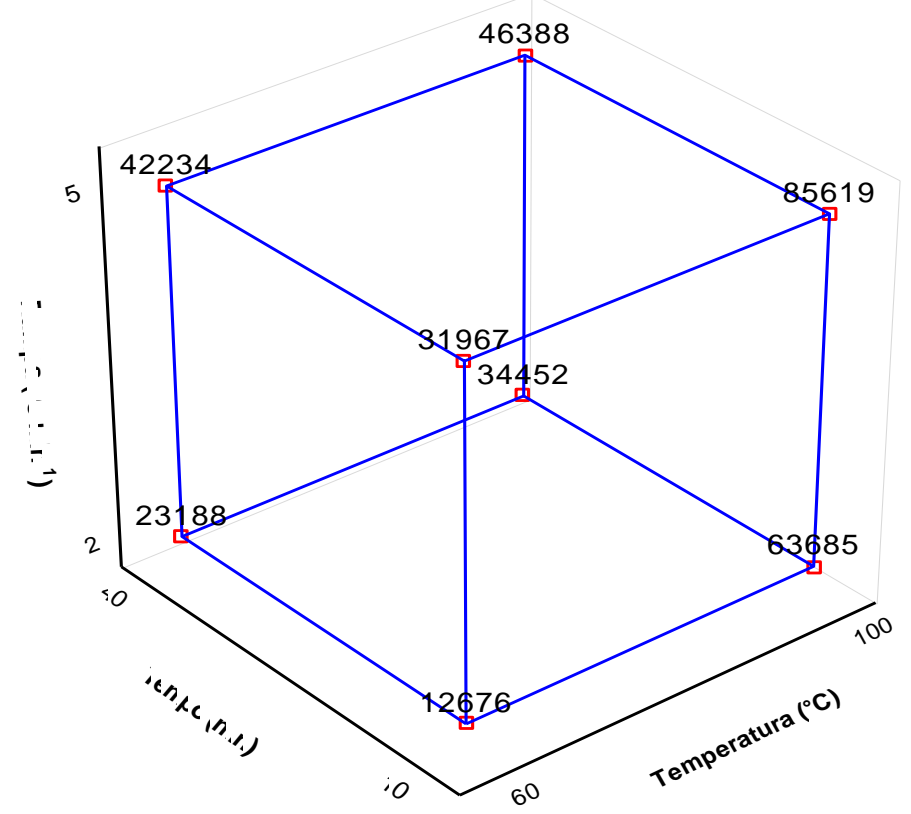

Fonte: Silva, Azevedo e Rezende, 2016.

A Tabela 11 mostra a estimativa dos efeitos principais e a interação entre eles no processo de extração.

Tabela 11 - Estimativa dos efeitos (planejamento $2^{3-0}$, variável-resposta: Área): $\mathrm{R}^{2}=0,999$; $\mathrm{R}_{\text {ajustado }}^{2}=0,999$.

\begin{tabular}{lcc}
\hline Fator & Efeito & $\begin{array}{c}\text { Intervalo de } \\
\text { Confiança (95\%) }\end{array}$ \\
\hline Intercepto & 42526,2 & $\pm 108,5$ \\
(1) Temperatura & 28778,1 & $\pm 217,1$ \\
(2) Tempo & $-13163,4$ & $\pm 434,2$ \\
(3) Rampa & 19293,6 & $\pm 217,1$ \\
(1) $\times(2)$ & $-22310,1$ & $\pm 217,1$ \\
$(1) \times(3)$ & $-1117,6$ & $\pm 217,1$ \\
$(2) \times(3)$ & $-2561,6$ & $\pm 217,1$ \\
\hline
\end{tabular}


De acordo com a Tabela 11, os parâmetros que mais afetam o rendimento da extração são a temperatura (1) e a rampa (3). O efeito da temperatura (positivo) permite afirmar que o aumento deste parâmetro no processo aumenta o rendimento da extração. O efeito do parâmetro tempo (negativo) indica que o rendimento é prejudicado com o aumento no tempo de extração. Todas as interações dos fatores avaliados mostraram efeito negativo, ou seja, a combinação de dois fatores não favorece o processo de extração, por exemplo, considerando-se o efeito da interação da temperatura com o tempo (1) x (2), pode-se inferir que o aumento na temperatura juntamente com o aumento no tempo de extração promove uma condição prejudicial ao processo. Sabendo-se que temperaturas acima de $100^{\circ} \mathrm{C}$ provavelmente modificariam a composição do solvente extrator utilizado, no caso a água, e o uso de um tempo maior de extração consequentemente causaria perda dos compostos fenólicos presentes no material por meio de degradação, o efeito negativo da interação entre os fatores (1) x (2) é confirmado.

Os efeitos dos fatores e as interações entre eles são ilustrados pelo gráfico de Pareto (Figura 14).

Figura 14 - Gráfico de Pareto dos efeitos.

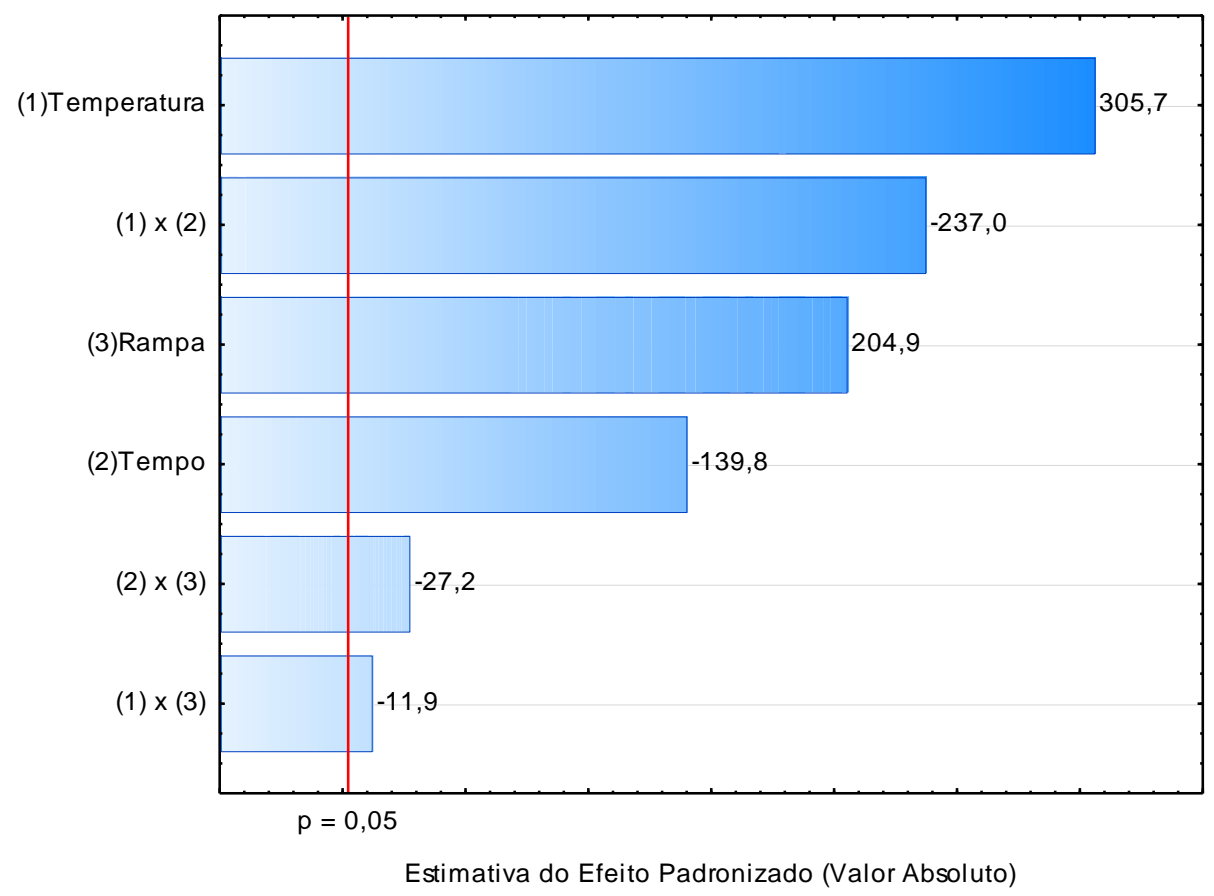

A boa linearidade entre os dados obtidos e os valores preditos pelo modelo é apresentada graficamente (Figura 15). A Figura 16 mostra os resíduos e os valores preditos pelo modelo ajustado, que representa uma boa aleatoriedade dos dados. 
Figura 15 - Valores preditos pelo modelo ajustado e valores observados experimentalmente.

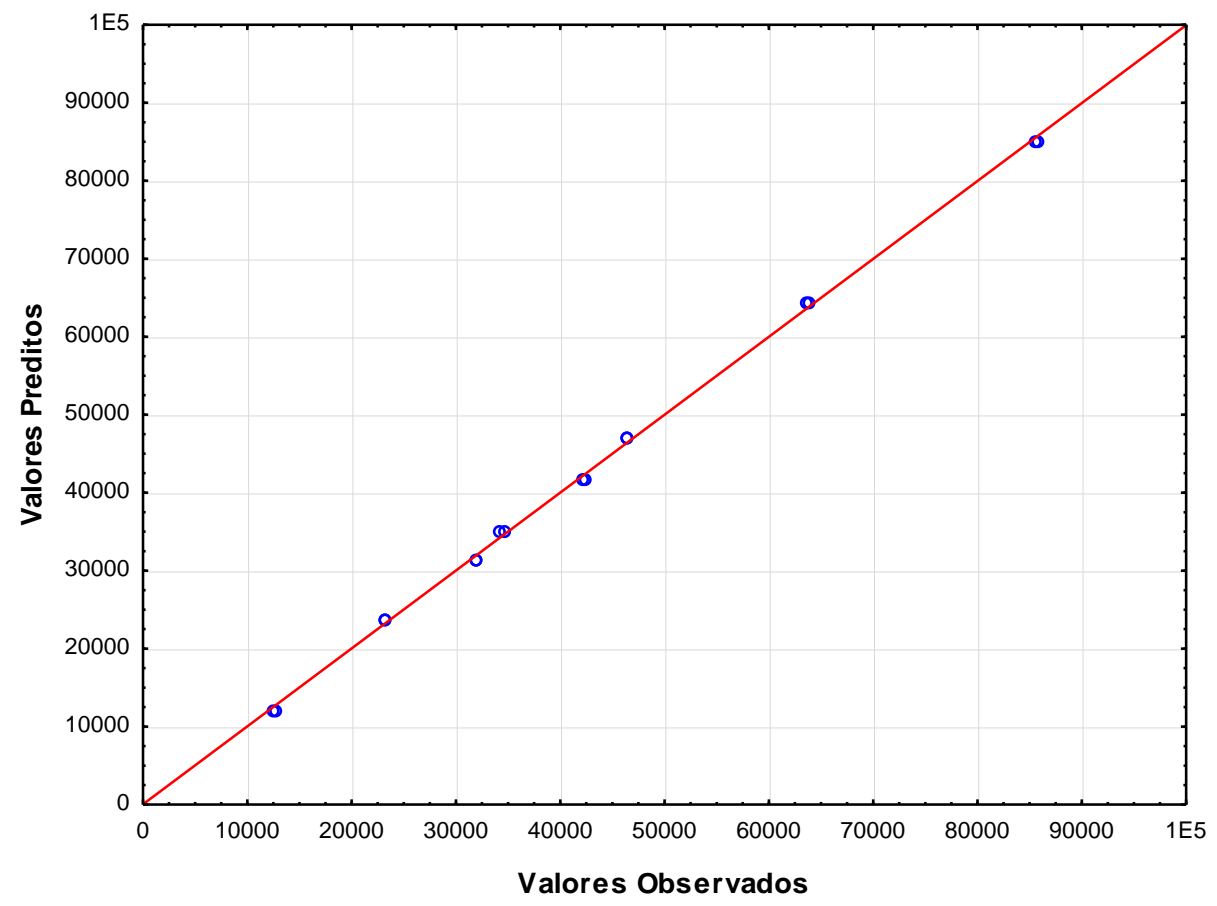

Figura 16 - Resíduos e valores preditos pelo modelo ajustado.

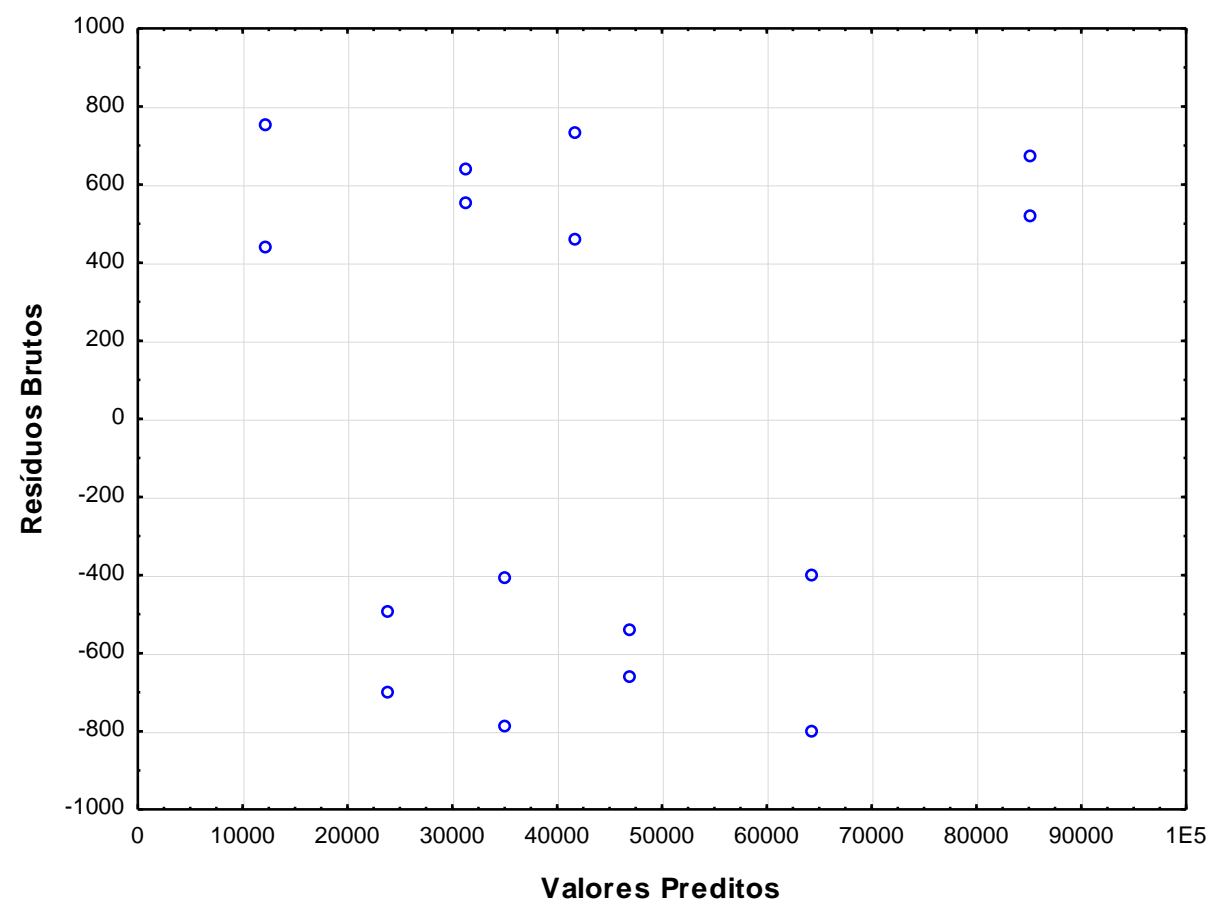




\subsubsection{Análise das superfícies de resposta}

Gráficos de superfície de resposta são muito úteis quando se quer visualizar os efeitos de dois fatores sobre a resposta, assim como a identificação dos valores ótimos, para obtenção da resposta máxima (KARABEGOVIC et al., 2013). Os gráficos foram plotados usando o eixo $\mathrm{z}$ (concentração em $\mathrm{mg} \mathrm{g}^{-1}$ ) contra duas variáveis independentes.

Metodologia da superfície de resposta (RSM) é um método estatístico que utiliza dados quantitativos de um planejamento fatorial para determinar ou, simultaneamente, resolver equações multivariadas. Diferente dos métodos empíricos convencionais, a RSM pode gerar um modelo matemático, levando em conta as possíveis inter-relações entre as variáveis de teste, minimizando o número de experimentos (SONG et al., 2011). Os efeitos das variáveis independentes (fatores) e suas interações sobre o rendimento da extração podem ser observados em três dimensões por meio da análise da superfície de resposta (HAYAT et al., 2009). As Figuras 17, 18 e 19 mostram as principais interações do processo: tempo x rampa; temperatura $\mathrm{x}$ rampa e temperatura $\mathrm{x}$ tempo.

Figura 17 - Gráfico de superfície de resposta mostrando os efeitos das variáveis tempo (min) $\mathrm{x}$ rampa (min) sobre a resposta (concentração em $\mathrm{mg} \mathrm{g}^{-1}$ ) obtida para o composto ácido ferúlico.

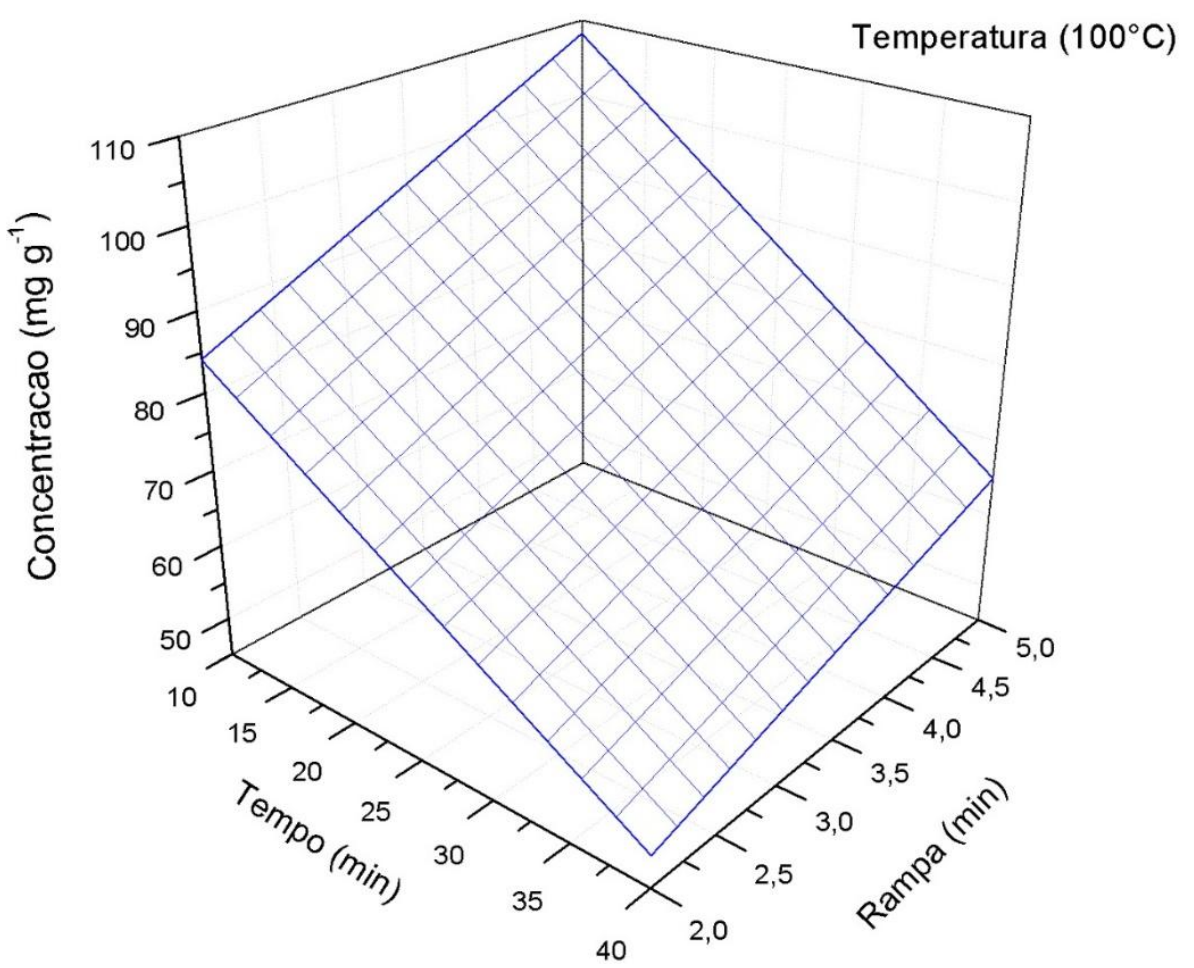

Fonte: Silva, Azevedo e Rezende, 2016. 
A Figura 17 mostra a interação entre o tempo e a rampa na concentração obtida para o composto ácido ferúlico. Aumentando-se a rampa de 3 a 5 minutos e diminuindo-se o tempo de extração de 30 para $10 \mathrm{~min}$, o rendimento da extração foi aumentado. A questão do aumento da rampa na programação do equipamento está relacionada ao tempo que o sistema leva para alcançar a temperatura máxima ajustada, para dar início à extração, em outras palavras, quanto maior o tempo de rampa mais rapidamente o equipamento atinge a temperatura programada. $\mathrm{O}$ aumento no tempo de extração está relacionado à degradação dos compostos.

Figura 18 - Gráfico de superfície de resposta mostrando os efeitos das variáveis rampa (min) $\mathrm{x}$ temperatura $\left({ }^{\circ} \mathrm{C}\right.$ ) sobre a resposta (concentração em $\mathrm{mg} \mathrm{g}^{-1}$ ) obtida para o composto ácido ferúlico.

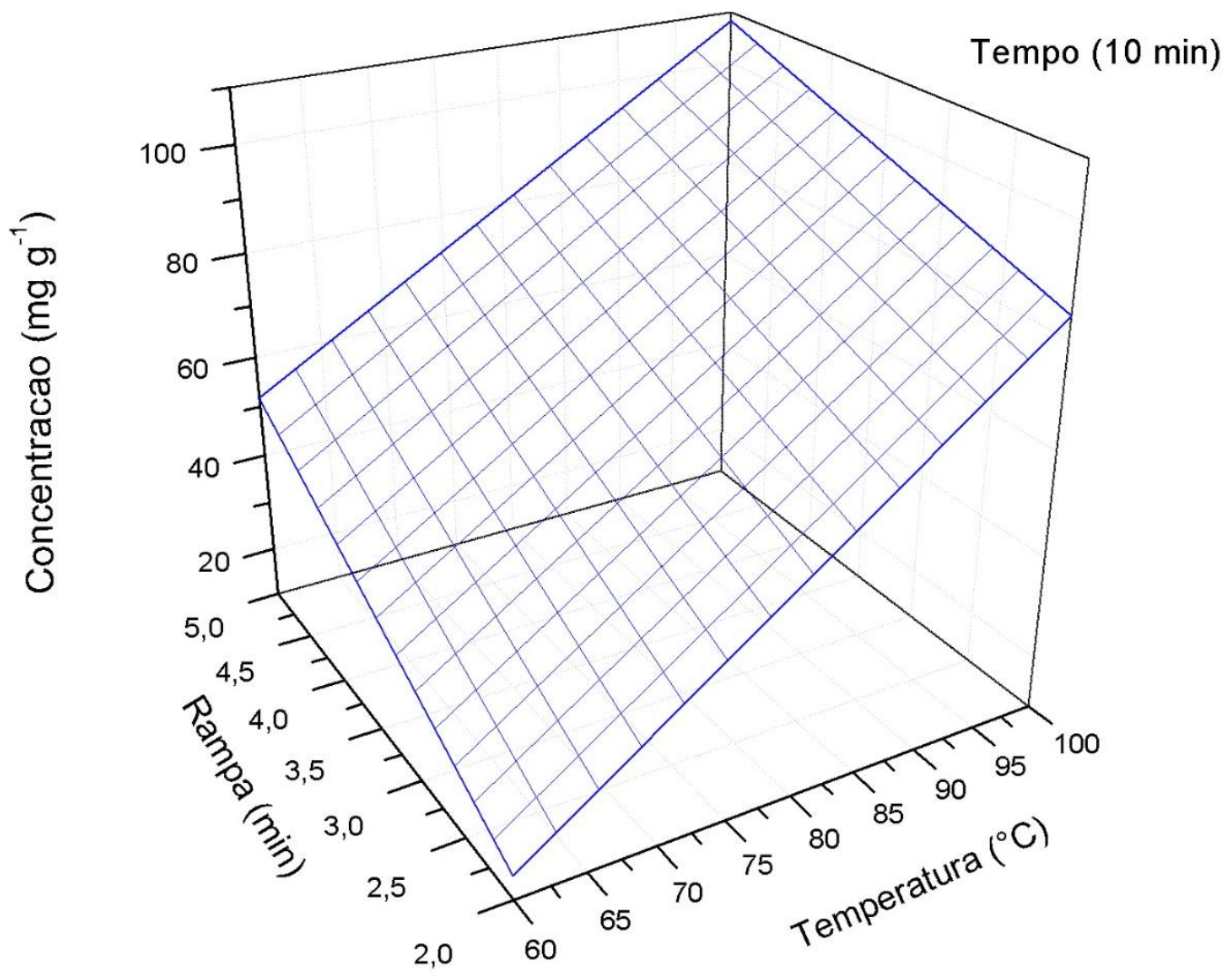

Fonte: Silva, Azevedo e Rezende, 2016.

A Figura 18 mostra a interação da temperatura com a rampa. Com o aumento do tempo de rampa de 3 a 5 minutos e o aumento da temperatura de extração de $85^{\circ} \mathrm{C}$ para $100^{\circ} \mathrm{C}$ min, o rendimento da extração aumenta. O aumento no tempo de rampa favorece o ajuste da temperatura máxima programada, ou seja, dentro de 5 minutos o equipamento consegue atingir $100^{\circ} \mathrm{C}$ dando início à extração. 
Figura 19 - Gráfico de superfície de resposta mostrando os efeitos das variáveis temperatura $\left({ }^{\circ} \mathrm{C}\right) \mathrm{x}$ tempo $(\mathrm{min})$ sobre a resposta (concentração em $\mathrm{mg} \mathrm{g}^{-1}$ ) obtida para o composto ácido ferúlico.

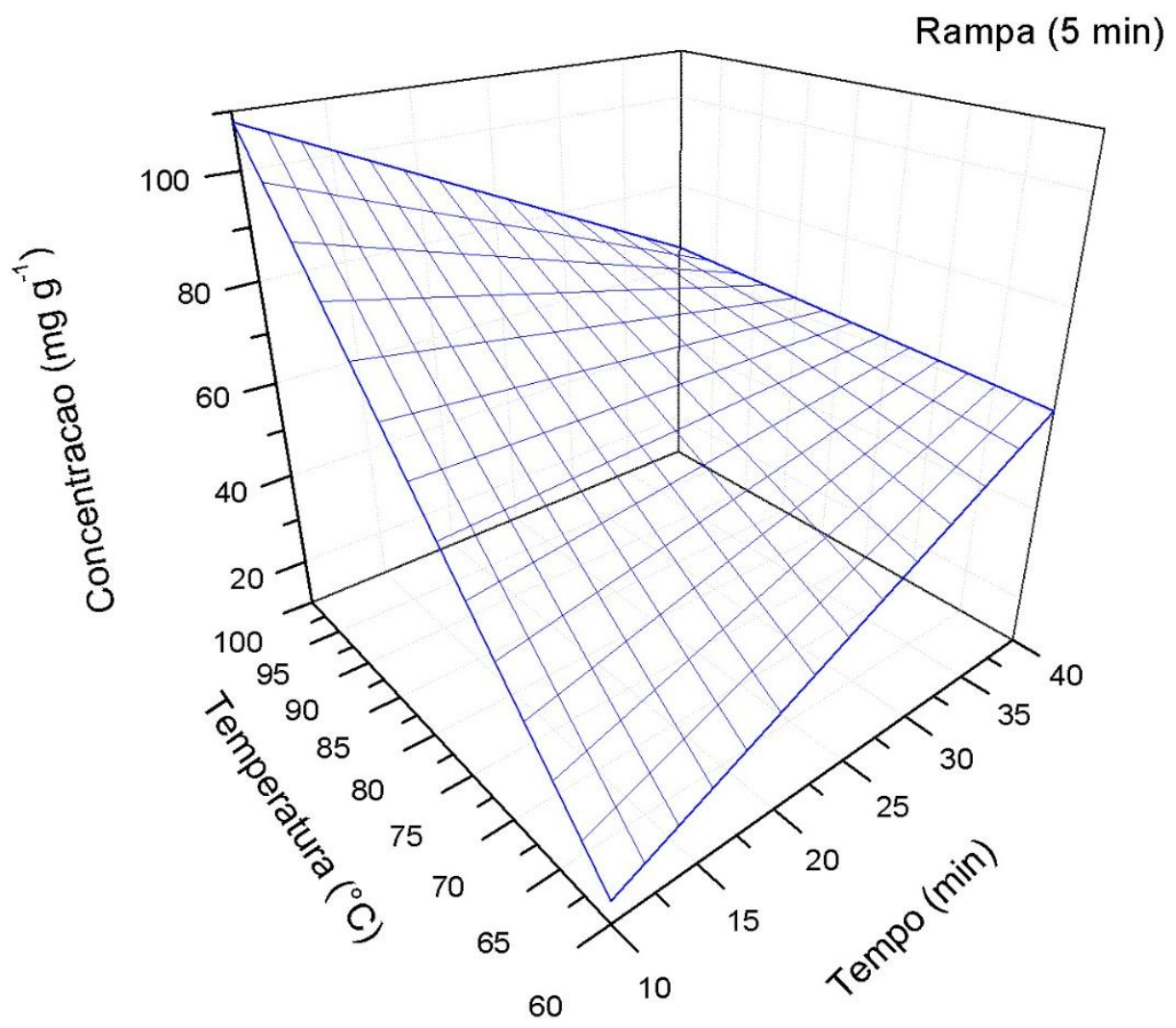

Fonte: Silva, Azevedo e Rezende, 2016.

A Figura 19 mostra que melhores respostas são alcançadas quando a temperatura aumenta de 80 para $100^{\circ} \mathrm{C}$ e o tempo diminui de 30 para 10 min. Esta condição mostra a influência da temperatura na extração, levando-se em consideração que o solvente utilizado é a água e que o possível aumento na temperatura acima de $100^{\circ} \mathrm{C}$ proporcionariam a mudança de fase do solvente. Já é sabido que longos tempos de extração (FILLY et al., 2014; PROESTOS; KOMAITIS, 2008; CASAZZA et al., 2010; UPADHYAY, RAMALAKSHMI; RAO, 2012; BALLARD et al., 2010), principalmente na obtenção de compostos fenólicos, promovem a degradação destes e prejudicam o rendimento do processo. Tal situação foi comprovada por esta análise. 


\subsubsection{Caminho de máxima inclinação}

Com a interpretação dos gráficos de superfície de resposta, seguiram-se os experimentos para definir o ponto ótimo na extração (caminho de máxima inclinação), utilizando-se o fator com o coeficiente de maior módulo no modelo (fator $i$ ) e deslocando-o inicialmente 0,3 unidades (escala codificada); em seguida calcularam-se os deslocamentos dos outros fatores $j$ $\neq i$ (escala codificada) através da Equação 8:

$$
\Delta x_{j}=\frac{b_{j}}{b_{i}} \Delta x_{i}
$$

Os deslocamentos calculados foram convertidos às unidades originais e, assim, os novos níveis foram determinados (Tabela 12), como no exemplo a seguir:

Exemplo: $\Delta x_{1}=0,3 \therefore \Delta x_{2}=-\frac{6.582}{14.389} \cdot 0,3=-0,138$

$$
\begin{aligned}
& x_{1}=1,3 \text { e } x_{2}=-1,138 \\
& \text { Temperatura }=20 \times x_{1}+80=20 \times 1,3+80=106^{\circ} \mathrm{C} \\
& \text { tempo }=15 \times x_{2}+25=15 \times(-1,138)+25=7,93 \mathrm{~min} \cong 8 \mathrm{~min}
\end{aligned}
$$

Esse procedimento foi repetido quatro vezes mais. Os cinco experimentos adicionais e seus respectivos níveis decodificados, com as respostas obtidas (áreas do pico para o ácido ferúlico) são apresentados na Tabela 12. 
Tabela 12 - Experimentos ao longo do caminho de máxima inclinação.

\section{Fatores}

(1) Temperatura $\left({ }^{\circ} \mathrm{C}\right)$

(2) Tempo (min)

(3) Rampa (min)

Área*

$\begin{array}{llll}100 & 10 & 5 & 85619 \\ 106 & 8 & 5 & 37408 \\ 112 & 6 & 6 & 35835 \\ 118 & 4 & 6 & 31154 \\ 124 & 2 & 6 & 20343\end{array}$

*Valores médios (duplicata)

Os experimentos ao longo do caminho de máxima inclinação/resposta indicaram que temperaturas acima de $100^{\circ} \mathrm{C}$ prejudicavam o processo de extração, evidenciado pelo aspecto de material queimado na parede dos frascos de extração, provavelmente devido ao ponto de ebulição do próprio solvente. Assim, novos experimentos foram realizados objetivando o decréscimo do tempo de extração e o aumento da rampa. A Tabela 13 mostra os novos experimentos realizados ao longo do caminho de máxima resposta, mantendo-se a temperatura constante $\left(100^{\circ} \mathrm{C}\right)$.

Tabela 13 - Experimentos ao longo do caminho de máxima inclinação $\left(\mathrm{t}=100^{\circ} \mathrm{C}\right)$.

Fatores

(2) Tempo (min) (3) Rampa (min)

Área*

\begin{tabular}{ccc}
\hline 10 & 5 & 85619 \\
10 & 8 & 51788 \\
5 & 8 & 31314 \\
\hline *Valores médios (duplicata) & &
\end{tabular}

Pode ser observado que nenhuma melhoria no processo de extração foi alcançada quando se utilizou um tempo de rampa de 8 minutos e um tempo de extração de 10 minutos. As respostas obtidas mostraram que o tempo total máximo de extração de 18 minutos (tempo de extração + rampa) prejudica o processo. Diminuindo-se o tempo de extração, os níveis no 
rendimento do processo são melhorados, ou seja, um tempo total de extração menor ou igual a 15 minutos não prejudica a estabilidade do solvente e, consequentemente, não promove a degradação dos compostos fenólicos presentes. Assim, os parâmetros otimizados na extração são apresentados na Tabela 14.

Tabela 14- Parâmetros otimizados do método de extração.

\begin{tabular}{lllll}
\hline Temperatura $\left({ }^{\circ} \mathrm{C}\right)$ & Pressão (bar) & Rampa $(\min )$ & Tempo (min) & Potência (\%) \\
\hline 100 & 35 & 5 & 10 & 60 \\
\hline
\end{tabular}

\subsection{Análise cromatográfica dos extratos}

\subsubsection{Validação do método}

A eficiência do processo de extração foi confirmada por HPLC-UV. A análise quantitativa dos compostos fenólicos foi feita por meio de uma curva analítica de 5 pontos. A metodologia foi validada de acordo com os parâmetros de linearidade, limite de detecção (LOD), limite de quantificação (LOQ), seletividade, sensibilidade e precisão. A seguir serão apresentados os conceitos dos parâmetros avaliados a fim de melhor apresentar os resultados.

\subsubsection{Seletividade}

É uma propriedade de um sistema de medição, utilizado com um procedimento de medição especificado, em que o sistema fornece valores medidos para um ou vários outros, de modo que os valores obtidos para cada medida sejam independentes entre si ou de outras grandezas associadas ao fenômeno ou substância em estudo (INMETRO, 2003).

Os procedimentos utilizados para demonstrar a seletividade vão depender do objetivo desejado da análise. Em geral, a verificação da seletividade do procedimento analítico deve ser realizada a partir da comparação entre os sinais (resposta do equipamento) advindos da amostra processada e do analito de interesse, em solução aquosa ou orgânica (INMETRO, 2003).

Para análise qualitativa (teste de identificação) é necessário demonstrar a capacidade de seleção entre compostos com estruturas relacionadas, que podem estar presentes. Isto deve ser confirmado pela obtenção de resultados positivos (preferencialmente em relação ao material de referência utilizado) em amostras contendo o analito, comparativamente com resultados 
negativos obtidos com amostras que não contém o analito, mas sim compostos estruturalmente semelhantes (INMETRO, 2003).

Para a análise quantitativa (teor) e análise de impurezas, a seletividade pode ser determinada pela comparação dos resultados obtidos de amostras (fármacos, medicamentos etc.) contaminadas com quantidades apropriadas de impurezas ou excipientes e amostras não contaminadas, para demonstrar que o resultado do teste não é afetado por aqueles materiais. Quando a impureza ou padrão do produto de degradação não estiverem disponíveis, pode-se comparar os resultados do teste das amostras contendo impurezas ou produtos de degradação com os resultados de um segundo procedimento bem caracterizado (por exemplo uma metodologia já validada). Estas comparações devem incluir amostras armazenadas sob condições de estresse (por exemplo, luz, calor, umidade, hidrólise ácida/básica, oxidação) (INMETRO, 2003).

Em procedimentos cromatográficos, devem-se tomar as precauções necessárias para garantir a resolução, adequada separação (pureza) dos picos cromatográficos. A utilização de testes de resolução de pico, por exemplo com auxílio de detector de arranjo de fotodiodos ou espectrometria de massas, é interessante para demonstrar que o pico cromatográfico é atribuído a um só componente (INMETRO, 2003). A Figura 20 apresenta o cromatograma obtido do material extraído por energia micro-ondas como exemplo da identificação dos analitos. 
Figura 20 - Cromatograma dos compostos extraídos via extração assistida por micro-ondas. Condições cromatográficas: volume de injeção de $20 \mu \mathrm{L}$; fase móvel $2 \%$ ácido acético glacial em água + metanol, 75:25 (v/v); fluxo da fase móvel 1,2 $\mathrm{mL} \mathrm{min}^{-1}$, temperatura da coluna: ambiente; detector: UV-Vis (282 nm). Picos: (1) rutina, (2) ácido ferúlico, (3) ácido clorogênico e (4) naringenina.

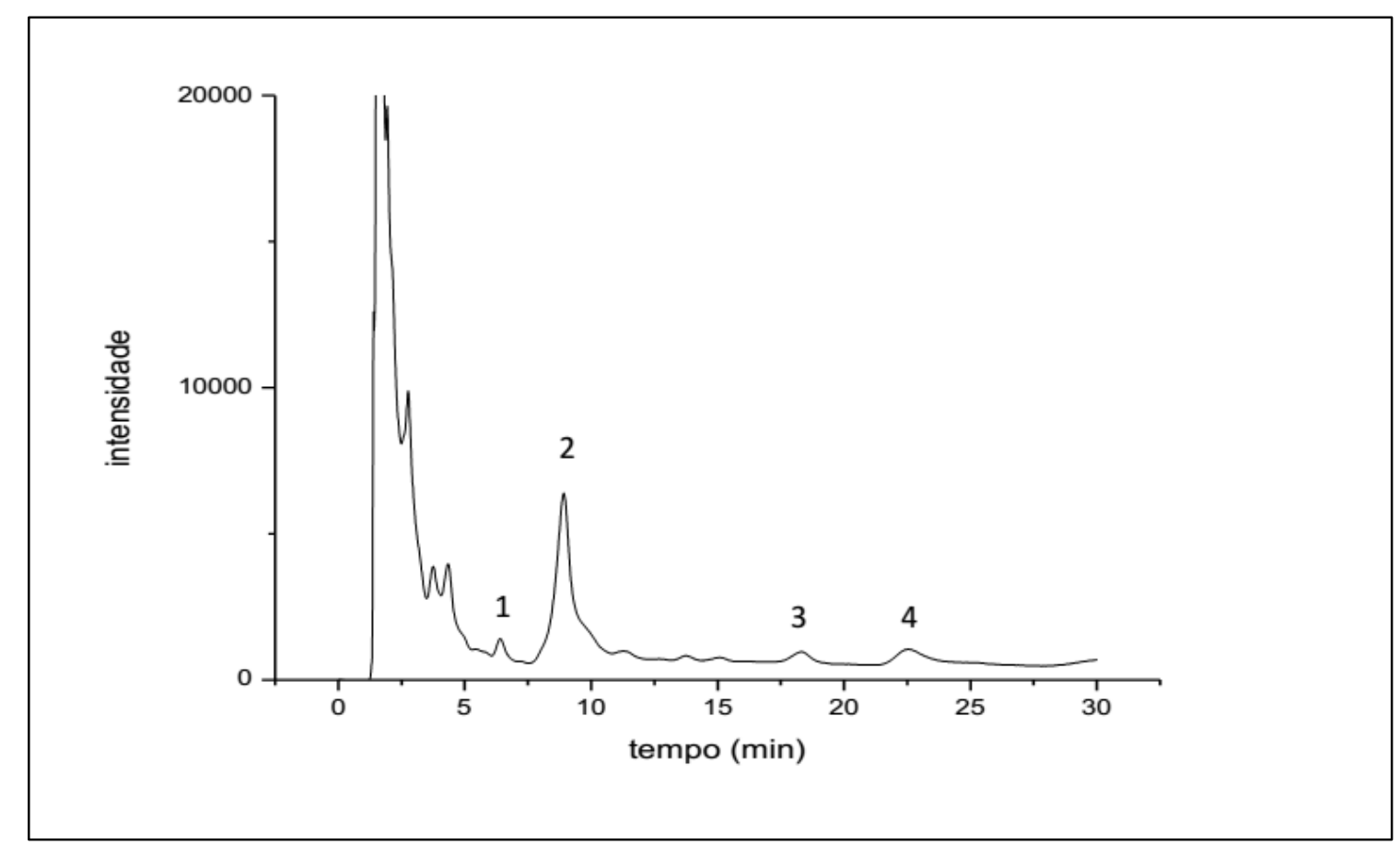

Fonte: Autoria própria.

A distinção entre os compostos não foi dificultada, já que os tempos de retenção observados foram compatíveis com os das soluções padrão inicialmente analisadas e nenhum interferente co-eluiu no mesmo tempo de retenção dos compostos de interesse.

\subsubsection{Efeito matriz}

É um estudo de seletividade cujo objetivo é averiguar possíveis interferências causadas pelas substâncias que compõem a matriz amostral gerando, basicamente, fenômenos de diminuição ou ampliação do sinal ou resposta do equipamento (INMETRO, 2003).

O estudo de efeito matriz é imprescindível quando se deseja trabalhar com uma curva de calibração não matrizada (analito em solvente puro) (INMETRO, 2003). 


\subsubsection{Linearidade (Curva de calibração)}

É a capacidade de o procedimento produzir resultados diretamente proporcionais à concentração do analito na amostra, dentro de um intervalo especificado. A faixa de trabalho linear da curva de calibração deve, necessariamente, contemplar a faixa de concentração esperada na amostra. Sempre que possível, o valor esperado para a amostra deve estar em torno do centro da curva de calibração. O número de níveis de concentração das soluções padrão de calibração deve ser, no mínimo, cinco ( $\geq 5$ ) (INMETRO, 2003).

\subsubsection{Precisão}

É a estimativa da dispersão dos resultados entre ensaios independentes, repetidos de uma mesma amostra, amostras semelhantes ou padrões, em condições definidas (INMETRO, 2003).

As três maneiras de expressá-la são por meio da repetitividade, da precisão (ou reprodutibilidade interna ou intralaboratorial) e da reprodutibilidade (INMETRO, 2003).

A reprodutibilidade é um procedimento analítico somente interlaboratorial colaborativo. Para se determinar a repetitividade deve-se preparar e analisar um conjunto de amostras constituídas de matrizes brancas fortificadas, no mínimo, em três níveis de concentração, com as substâncias a serem analisadas. A repetitividade é dada pelo coeficiente de variação (C.V \%) (INMETRO, 2003).

\subsubsection{Limite de detecção}

O limite de detecção do equipamento é definido como a concentração do analito que produz um sinal de três vezes a razão sinal/ruído do equipamento (INMETRO, 2003).

\subsubsection{Limite de quantificação}

O limite de quantificação do procedimento analítico é definido como o nível mais baixo de concentração no qual foi demonstrado que os critérios de veracidade e precisão foram atendidos (INMETRO, 2003). 
Os limites de detecção (LOD) e de quantificação (LOQ) foram determinados via linearidade da curva analítica. Para os cálculos dos limites de detecção e quantificação foram utilizadas as equações a seguir:

$$
\mathrm{LOD}=\frac{(D \times 3)}{a}
$$

Onde: D é o desvio padrão do coeficiente linear da curva analítica;

E $\boldsymbol{a}$ é o coeficiente angular da reta.

E para os cálculos do limite de quantificação:

$$
\mathrm{LOQ}=\frac{(D \times 10)}{a}
$$

Quanto à linearidade, foram construídas curvas analíticas para cada composto a partir da injeção das soluções padrão nas concentrações $\left(1,0 ; 2,0 ; 5,0 ; 10,0\right.$ e 25,0 mg L $\left.\mathrm{m}^{-1}\right)$. Todas as determinações foram feitas em triplicata para cada nível de concentração. As curvas analíticas das soluções padrão apresentaram coeficientes de determinação superiores a 0,99. As Figuras 21-24 apresentam as curvas analíticas dos compostos analisados. 
Figura 21 - Curva analítica ácido clorogênico. Condições cromatográficas: volume de injeção de $20 \mu \mathrm{L}$; fase móvel $2 \%$ ácido acético glacial em água + metanol, 75:25 (v/v); fluxo da fase móvel 1,2 $\mathrm{mL} \mathrm{min}^{-1}$, temperatura da coluna: ambiente; detector: UV-Vis (282nm).

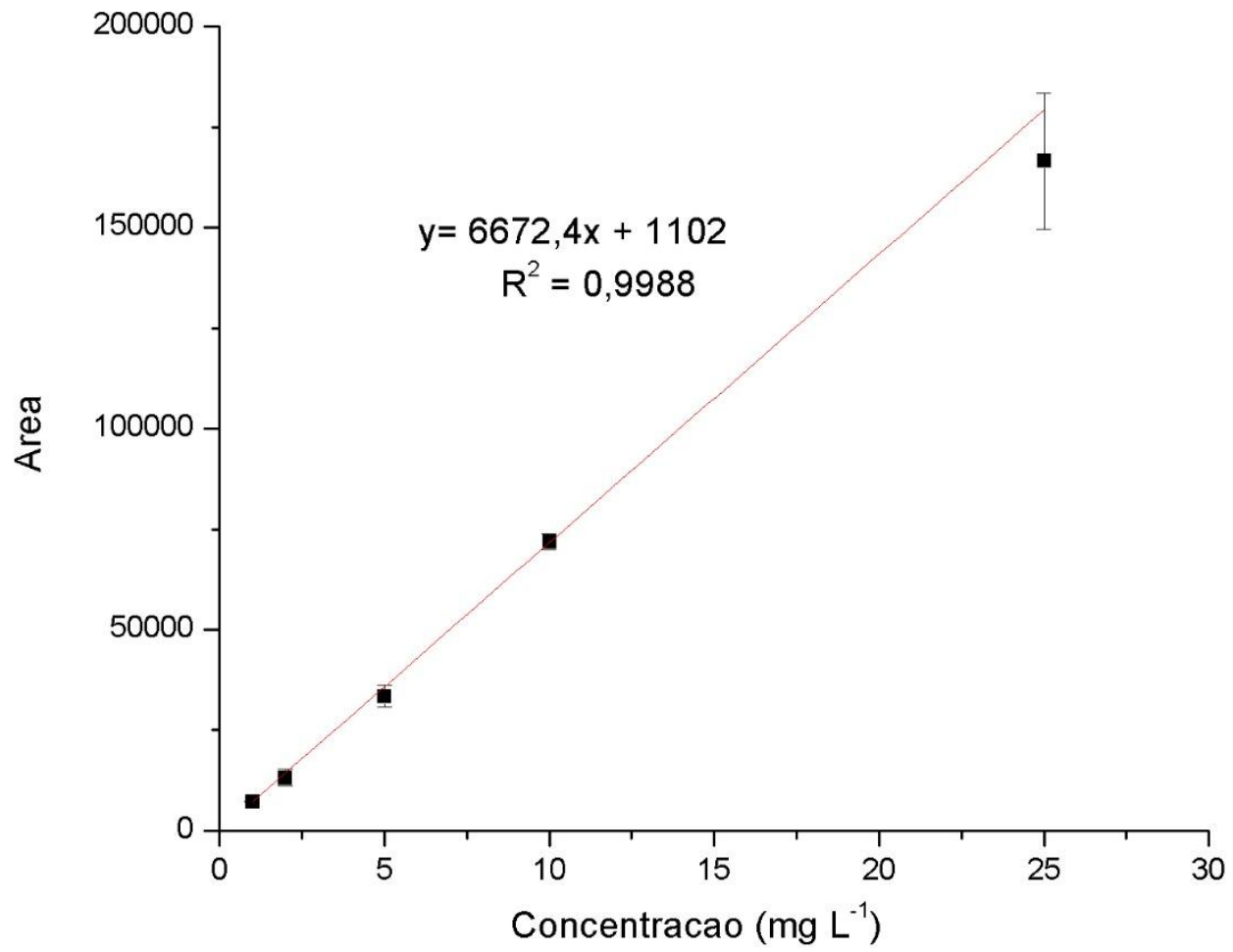

Fonte: Autoria própria. 
Figura 22 - Curva analítica rutina. Condições cromatográficas: volume de injeção de $20 \mu \mathrm{L}$; fase móvel $2 \%$ ácido acético glacial em água + metanol, 75:25 (v/v); fluxo da fase móvel 1,2 $\mathrm{mL} \min ^{-1}$, temperatura da coluna: ambiente; detector: UV-Vis $(282 \mathrm{~nm})$.

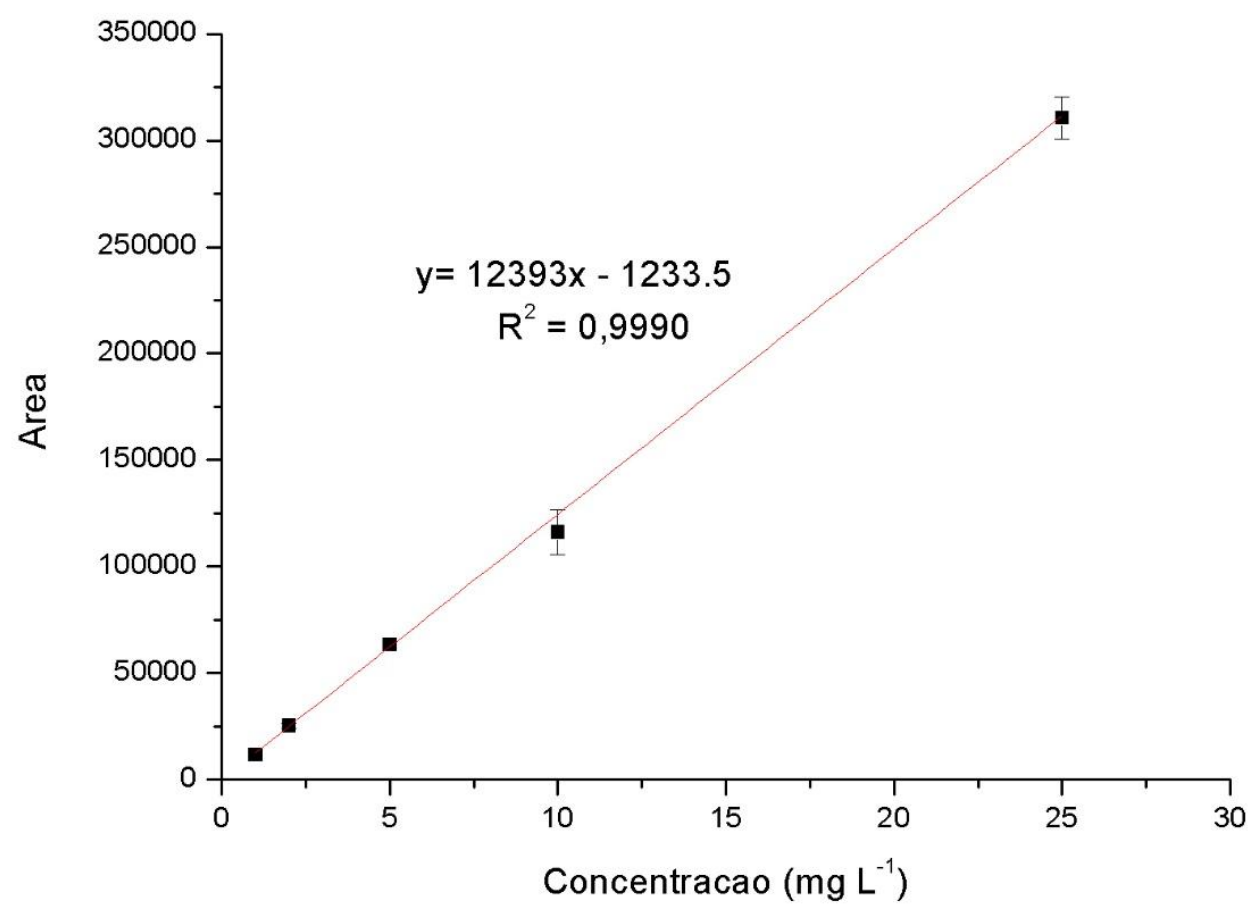

Fonte: Autoria própria. 
Figura 23 - Curva analítica naringenina. Condições cromatográficas: volume de injeção de 20 $\mu \mathrm{L}$; fase móvel $2 \%$ ácido acético glacial em água + metanol, 75:25 (v/v); fluxo da fase móvel $1,2 \mathrm{~mL} \mathrm{~min}^{-1}$, temperatura da coluna: ambiente; detector: UV-Vis (282nm).

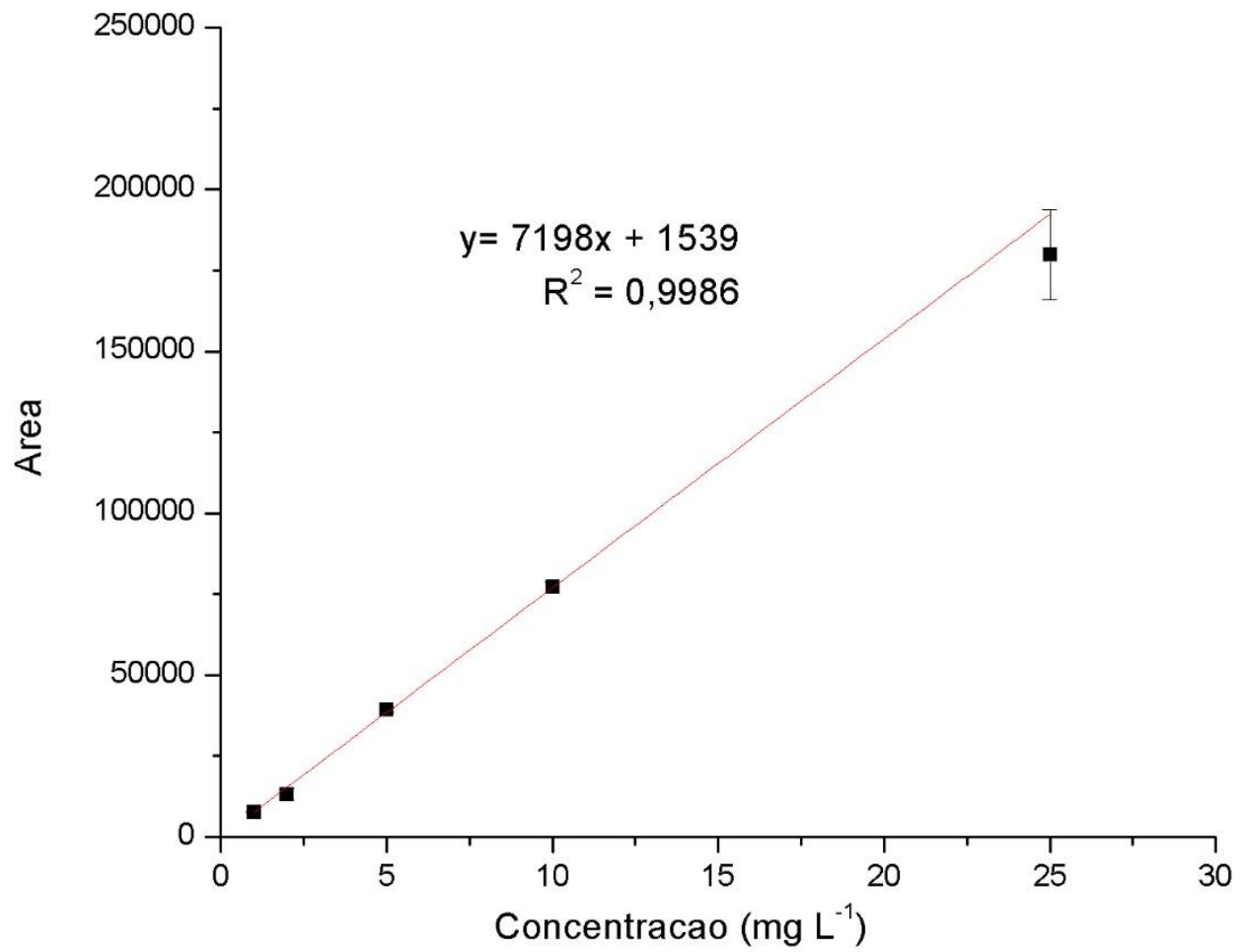

Fonte: Autoria própria. 
Figura 24 - Curva analítica ácido ferúlico. Condições cromatográficas: volume de injeção de $20 \mu \mathrm{L}$; fase móvel $2 \%$ ácido acético glacial em água + metanol, 75:25 (v/v); fluxo da fase móvel 1,2 $\mathrm{mL} \mathrm{min}^{-1}$, temperatura da coluna: ambiente; detector: $\mathrm{UV}$-Vis (282nm).

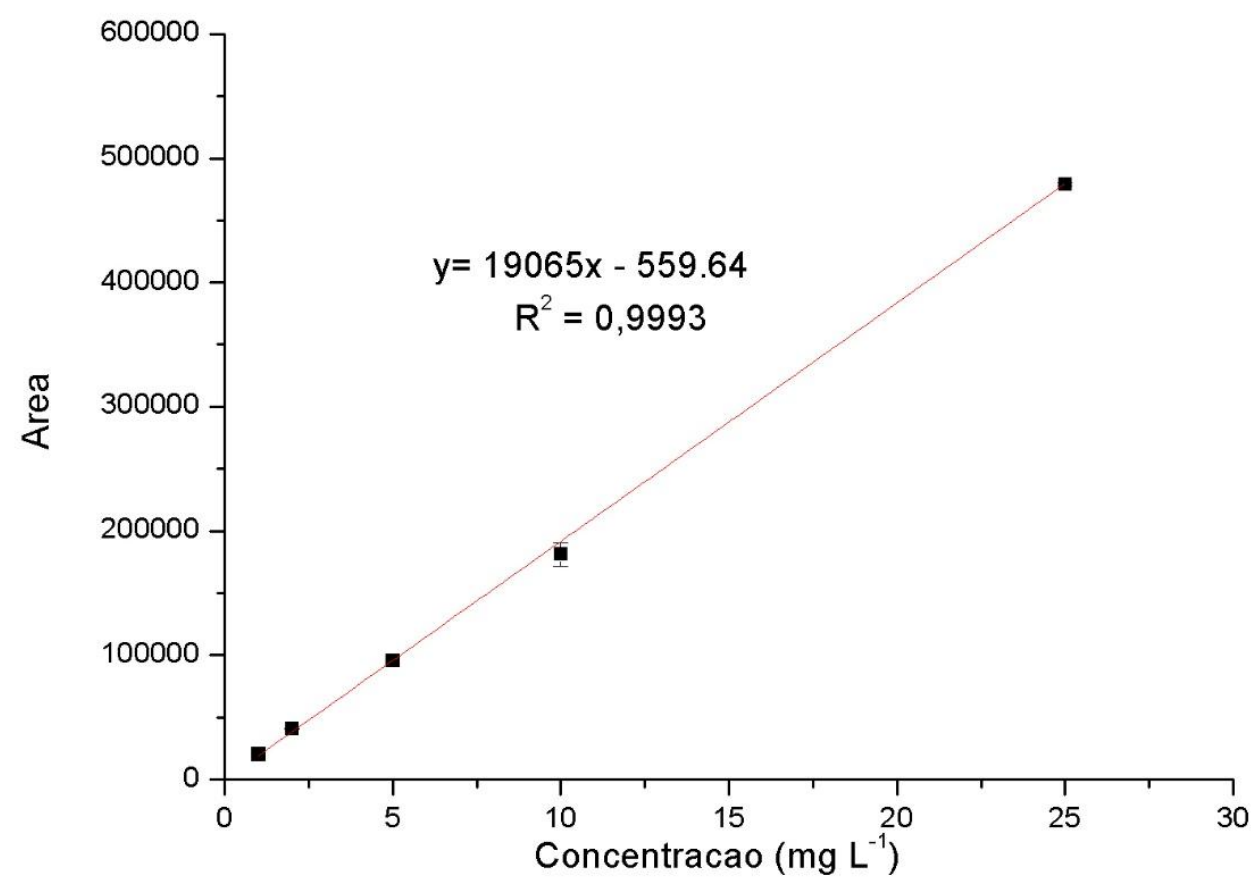

Fonte: Autoria própria.

A partir destes dados foi feita a análise quantitativa dos compostos presentes nos extratos aquosos obtidos das folhas do feijão-de-porco a partir de extração por micro-ondas. Na Tabela 15 estão dispostos os dados de regressão linear, LOD, LOQ dos compostos analisados.

Tabela 15 - Regressão linear, coeficiente de determinação, LOD e LOQ dos compostos analisados.

\begin{tabular}{llccc}
\hline Analitos & Regressão linear & $\mathrm{R}^{2}$ & $\begin{array}{c}\mathrm{LOD} \\
\left(\mathrm{mg} \mathrm{L}^{-1}\right)\end{array}$ & $\begin{array}{c}\text { LOQ } \\
\left(\mathrm{mg} \mathrm{L}^{-1}\right)\end{array}$ \\
\hline Ácido ferúlico & $\mathrm{y}=19065 \mathrm{x}-559,64$ & 0,9993 & 0,0968 & 0,2935 \\
Ácido clorogênico & $\mathrm{y}=6672,4 \mathrm{x}+1102$ & 0,9988 & 0,5450 & 1,6515 \\
Naringenina & $\mathrm{y}=7198 \mathrm{x}+1539$ & 0,9986 & 0,7055 & 2,1380 \\
Rutina & $\mathrm{y}=12393 \mathrm{x}-1233,5$ & 0,9990 & 0,3284 & 0,9953 \\
& & & & \\
\hline
\end{tabular}




\subsubsection{Ensaios de recuperação}

Os testes de recuperação das amostras foram realizados seguindo a metodologia de extração assistida via micro-ondas, conforme programação da Tabela 8 (página 74). Os resultados das recuperações para os 3 níveis de fortificação estão dispostos na Tabela 6. Os dados de recuperação foram calculados através da Equação 11:

$$
\operatorname{Rec}=\frac{\text { Cmed }}{\text { Cpad }} \times 100
$$

Onde: Cmed é a concentração medida;

e Cpad é a concentração real do material de referência

A precisão do método foi determinada pela concordância dos valores obtidos e os valores de fortificação. Expresso pelo coeficiente de variação (CV\%), segundo a Equação 12:

$$
\mathrm{CV}(\%)=\frac{D}{\text { Cmed }} \times 100
$$

Onde: D é o desvio padrão dos dados

As Figuras 25-28 apresentam os cromatogramas obtidos nos ensaios de recuperação dos compostos ácido clorogênico, naringenina, rutina e ácido ferúlico, respectivamente, nos níveis de fortificação de 2,5 e $10 \mathrm{mg} \mathrm{L}^{-1}$. 
Figura 25 - Cromatogramas dos extratos aquosos obtidos após MAE. (1) Ácido clorogênico. Concentrações de fortificação de 2,5 e $10 \mathrm{mg}$. $\mathrm{L}^{-1}$. Condições cromatográficas: volume de injeção de $20 \mu \mathrm{L}$; fase móvel $2 \%$ ácido acético glacial em água + metanol, 75:25 (v/v); fluxo da fase móvel 1,2 $\mathrm{mL} \mathrm{min}^{-1}$, temperatura da coluna: ambiente; detector: UV-Vis $(282 \mathrm{~nm})$. Tempo de retenção: 16,25 min.

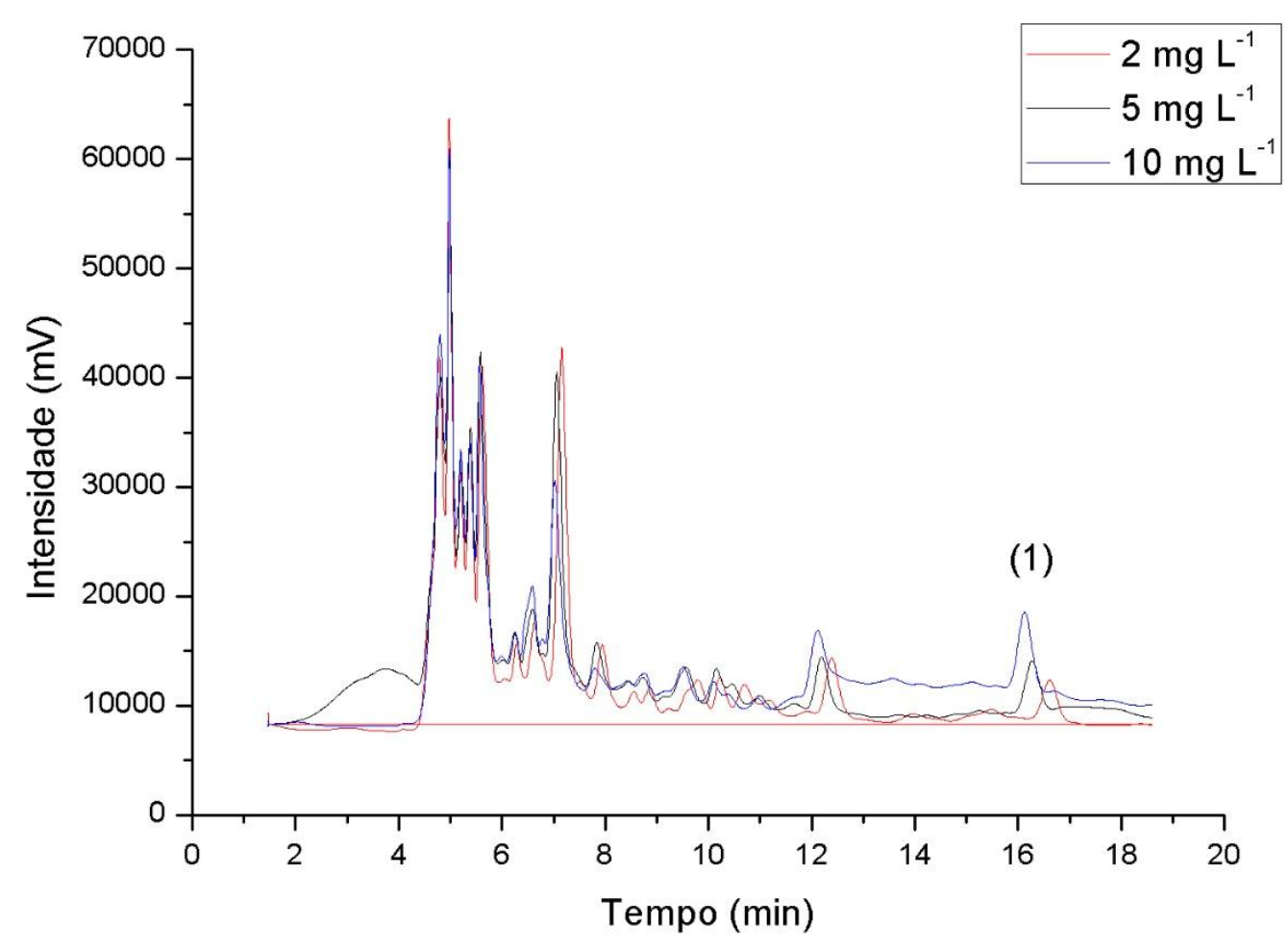

Fonte: Autoria própria. 
Figura 26 - Cromatogramas dos extratos aquosos obtidos após MAE. (1) Naringenina. Concentrações de fortificação de 2,5 e $10 \mathrm{mg}$. $\mathrm{L}^{-1}$. Condições cromatográficas: volume de injeção de $20 \mu \mathrm{L}$; fase móvel $2 \%$ ácido acético glacial em água + metanol, 75:25 (v/v); fluxo da fase móvel 1,2 $\mathrm{mL} \mathrm{min}^{-1}$, temperatura da coluna: ambiente; detector: UV-Vis $(282 \mathrm{~nm})$. Tempo de retenção: 22,50 min.

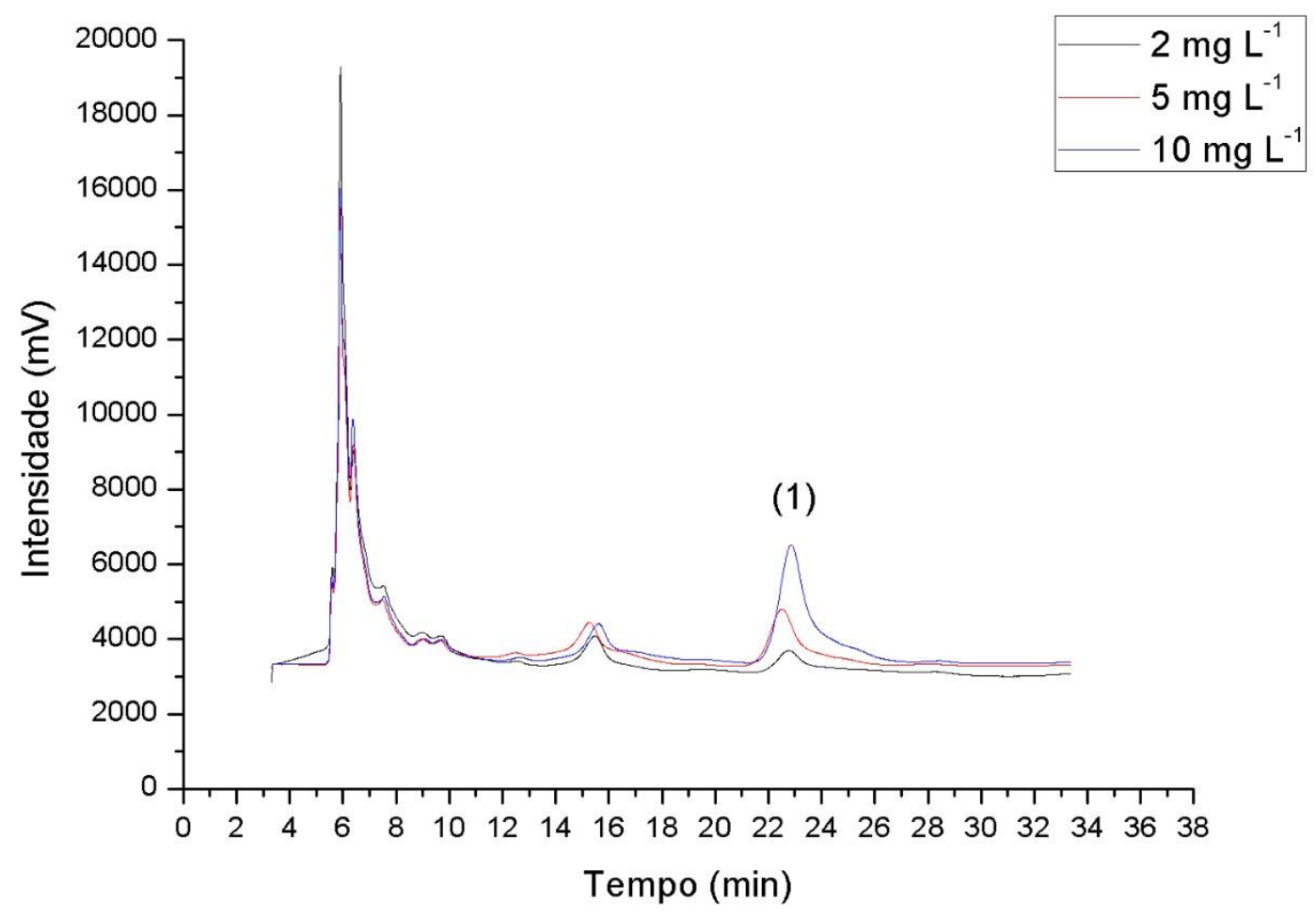

Fonte: Autoria própria. 
Figura 27 - Cromatogramas dos extratos aquosos obtidos após MAE. (1) Rutina. Concentrações de fortificação de 2,5 e $10 \mathrm{mg}$. $\mathrm{L}^{-1}$. Condições cromatográficas: volume de injeção de $20 \mu \mathrm{L}$; fase móvel $2 \%$ ácido acético glacial em água + metanol, 75:25 (v/v); fluxo da fase móvel 1,2 $\mathrm{mL} \mathrm{min}^{-1}$, temperatura da coluna: ambiente; detector: UV-Vis (282 nm). Tempo de retenção: 2,85 min.

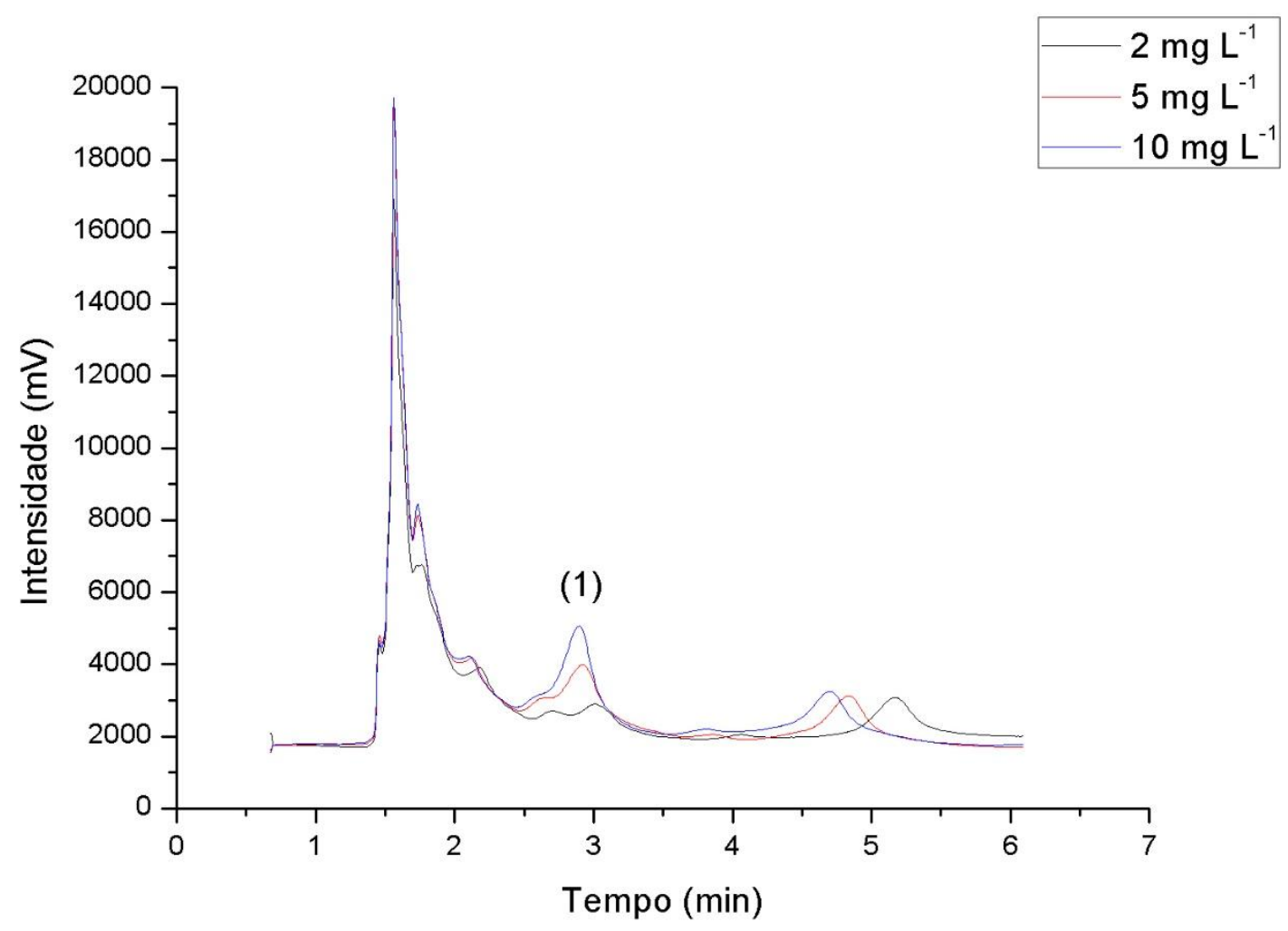

Fonte: Autoria própria. 
Figura 28 - Cromatogramas dos extratos aquosos obtidos após MAE. (1) Ácido ferúlico. Concentrações de fortificação: (a) extrato; (b) $2 \mathrm{mg}$. L ${ }^{-1}$; (c) $5 \mathrm{mg}$. L $\mathrm{L}^{-1}$; (d) $10 \mathrm{mg}$. L ${ }^{-1}$. Condições cromatográficas: volume de injeção de $20 \mu \mathrm{L}$; fase móvel $2 \%$ ácido acético glacial em água + metanol, 75:25 (v/v); fluxo da fase móvel $1,2 \mathrm{~mL} \mathrm{~min}^{-1}$, temperatura da coluna: ambiente; detector: UV-Vis $(282 \mathrm{~nm})$. Tempo de retenção: 10,61 min.

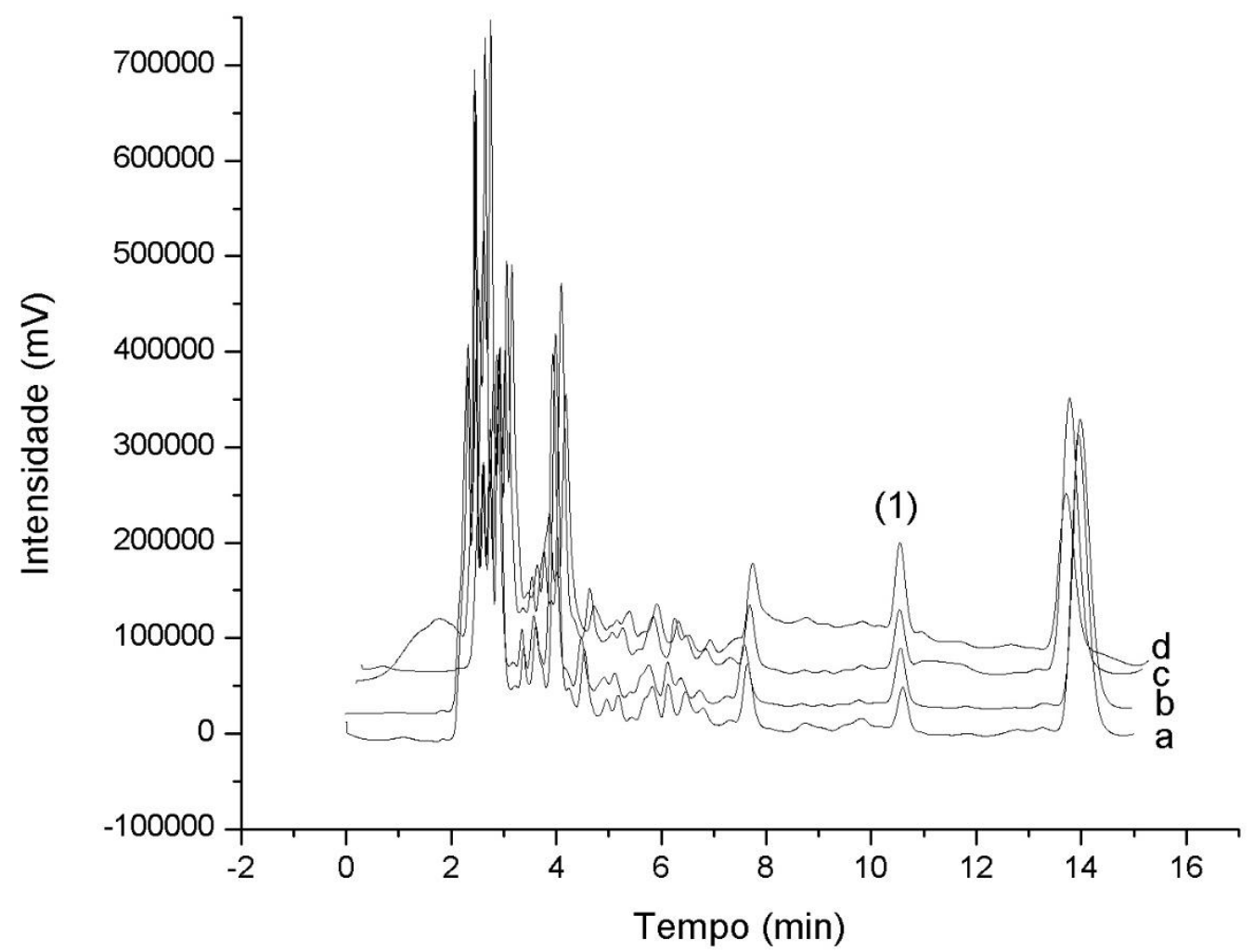

Fonte: Autoria própria.

Todas as determinações feitas nas concentrações de 2, 5 e $10 \mathrm{mg} \mathrm{L}^{-1}$ foram satisfatórias quanto à faixa de exatidão comumente aplicável, que está entre 80 a 120\%, considerando-se a precisão do método $(<8 \%)$ (Tabela 16) (ANVISA, 2003).

Como forma de verificar a linearidade e, consequentemente, comprovar a proporcionalidade do estudo de recuperação, verificou-se a exatidão do processo por meio da linearidade entre a concentração de fortificação e a concentração recuperada do método (Figura 29). 
Figura 29 - Relação entre a concentração recuperada e a concentração de fortificação, com níveis variando entre 2,0 e $10,0 \mathrm{mg} \mathrm{L}^{-1}$.

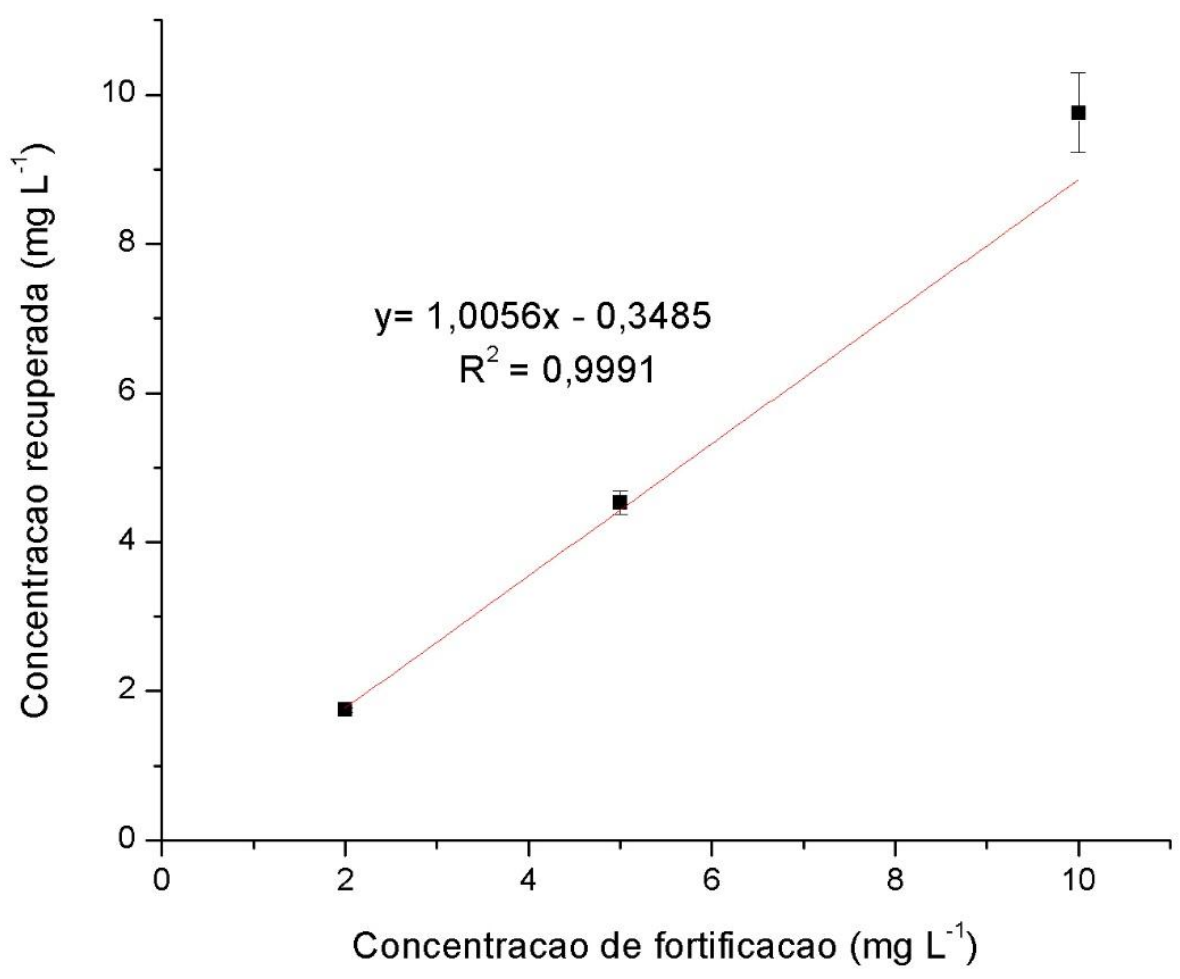

Partindo-se da ideia de que o estudo da exatidão de um método por meio da regressão linear considera que o coeficiente linear deve ser o mais próximo possível de 0 (zero) e o coeficiente angular igual a 1, pode-se dizer que os ensaios de recuperação apresentaram boa proporcionalidade (coeficiente de correlação $=0,9991$ ), com coeficientes numericamente próximos ao esperado.

A Tabela 16 apresenta os dados das recuperações médias dos compostos ácido ferúlico, ácido clorogênico, rutina e naringenina em níveis de fortificação de 2,5 e $10 \mathrm{mg} \mathrm{L}^{-1}$ nos extratos aquosos obtidos via extração assistida por micro-ondas das folhas da Canavalia ensiformis. 
Tabela 16 - Recuperações médias $(\mathrm{n}=3)$ de ácido ferúlico, ácido clorogênico, rutina e naringenina em níveis de fortificação de 2,5 e 10 mg L ${ }^{-1}$, em extratos aquosos obtidos via extração assistida por micro-ondas das folhas da Canavalia ensiformis.
Níveis de
Ácido Férulico
Ácido Clorogênico
Rutina
Naringenina

fortificação

$\left(\mathrm{mg} \mathrm{L}^{-1}\right)$

\begin{tabular}{|c|c|c|c|c|c|c|c|c|}
\hline & $\begin{array}{l}\text { Recuperação } \\
(\%)\end{array}$ & C.V. & $\begin{array}{l}\text { Recuperação } \\
(\%)\end{array}$ & C.V. & $\begin{array}{l}\text { Recuperação } \\
(\%)\end{array}$ & C.V. & $\begin{array}{l}\text { Recuperação } \\
(\%)\end{array}$ & C.V. \\
\hline 2 & $87,5 \pm 0,78$ & 1,71 & $93,5 \pm 1,34$ & 3,98 & $99,5 \pm 1,76$ & 4,41 & $73,5 \pm 1,28$ & 2,34 \\
\hline 5 & $91,0 \pm 1,02$ & 3,64 & $118,4 \pm 0,76$ & 1,95 & $101,2 \pm 1,22$ & 5,29 & $100,8 \pm 0,85$ & 3,88 \\
\hline 10 & $98,6 \pm 0,98$ & 7,46 & $111,1 \pm 0,88$ & 3,12 & $96,0 \pm 1,05$ & 1,86 & $113,9 \pm 1,08$ & 6,23 \\
\hline
\end{tabular}

C.V.:Coeficiente de variação. 
Metodologias de extração que utilizam água como solvente resultam em baixa quantidade de compostos fenólicos extraídos quando comparadas com os métodos tradicionais de extração. A água tem a mais alta constante dielétrica $(\varepsilon=80)$ dos solventes, entretanto o fator de dissipação é significativamente mais baixo que o dos outros solventes $\left(\delta=1500 \times 10^{4}\right)$. Consequentemente, a faixa em que a água absorve energias micro-ondas é maior que a faixa em que o sistema pode dissipar calor. Assim, o aquecimento intenso pode causar a degradação dos analitos (PROESTOS, 2008). Os resultados das recuperações e da precisão nos testes mostraram que a metodologia de extração via micro-ondas foi adequada, com recuperações na faixa de 87,5 - 118,4\%. Considerando-se a complexidade da matriz, a precisão do método foi satisfatória, variando de 1,7 a 7,4\%.

\subsection{Testes iniciais do potencial alelopático dos extratos aquosos contendo os compostos com atividade bioerbicida obtido via extração assistida por micro-ondas}

O objetivo principal do trabalho era comprovar a capacidade herbicida e a seletividade dos extratos aquosos aplicados em pós-emergência sobre as plantas invasoras Emilia sonchifolia e Sida spinosa e na cultura de soja convencional. Nas avaliações de toxicidade, tanto para a cultura de soja quanto para as plantas invasoras, consideramos as características visuais, as medidas da altura e comprimento das folhas da planta como base para obtenção da porcentagem de injúria e/ou controle.

Assim, foram preparados extratos aquosos nas concentrações de 100, 125, 150 e $200 \mathrm{~g}$ $\mathrm{L}^{-1}$ que foram aplicados inicialmente na planta invasora falsa serralha (Emilia sonchifolia) e na soja convencional após a germinação das sementes, conforme descrito na metodologia item 3.5.

\subsubsection{Definição do volume de extrato aquoso para aplicação foliar na planta invasora Emilia sonchifolia}

Com as concentrações preparadas de 100, 125, 150 e $200 \mathrm{~g} \mathrm{~L}^{-1}$, aplicando-se uma dose única de aproximadamente 1,5 mL por planta, não foram observadas quaisquer injúrias nas plantas invasoras. Os tratamentos referentes às concentrações de 100, 125 e $150 \mathrm{~g} \mathrm{~L}^{-1}$ foram avaliados até $15^{\circ}$ dia após a primeira aplicação dos extratos. Nesse período, não causaram injúrias. Outros testes foram realizados utilizando-se o volume de 3,0 mL por planta. Os tratamentos referentes às concentrações de 100, 125 e $150 \mathrm{~g} \mathrm{~L}^{-1}$, avaliados até um período de 15 dias, tampouco apresentaram efeito fitotóxico. 
Com o tratamento na concentração de $200 \mathrm{~g} \mathrm{~L}^{-1}$, utilizando-se o volume para aplicação de 3,0 mL por planta, os sintomas de fitotoxicidade tiveram início $24 \mathrm{~h}$ após a aplicação dos extratos. Das características observadas, temos a mudança na coloração das folhas que ganham um tom amarelado, o aparecimento de manchas na cor marrom (correspondentes à área atingida pela pulverização/borrifação direta nas folhas da planta Emilia sonchifolia) e a apoptose das folhas partindo de sua extremidade.

\subsubsection{Avaliação dos efeitos observados}

A avaliação utilizada para definir a toxicidade dos tratamentos foi baseada numa escala conceitual alfabética (Tabela 17) da Sociedade Brasileira da Ciência das Plantas DaninhasSPCPD, que varia de "a" até "e", descrevendo detalhadamente os sintomas apresentados pelas plantas ao final dos tratamentos.

Tabela 17 - Descrição dos conceitos aplicados às avaliações de toxicidade segundo a SBCPD.

\begin{tabular}{|c|c|}
\hline Conceito & Descrição \\
\hline $\mathrm{a}$ & Sem injúria ou efeito \\
\hline $\mathrm{b}$ & Injúria leve e/ou redução do crescimento com rápida recuperação \\
\hline $\mathrm{c}$ & $\begin{array}{l}\text { Injúria moderada e/ou redução do crescimento com lenta } \\
\text { recuperação ou definitiva }\end{array}$ \\
\hline $\mathrm{d}$ & $\begin{array}{l}\text { Injúrias severas e/ou redução do crescimento não recuperáveis e/ou } \\
\text { redução do estande }\end{array}$ \\
\hline $\mathrm{e}$ & Destruição completa da cultura ou somente algumas plantas vivas \\
\hline
\end{tabular}

Fonte: SPCPD, 1995.

Para avaliação do controle das plantas invasoras na plantação de soja ao longo do experimento, utilizou-se também a escala de notas da Associación Latinoamericana de Malezas (ALAM, 1974) (Tabela 18) que varia entre 0 (zero) e 100 (cem), sendo 0 a ausência de controle e 100 o controle total das plantas invasoras. 
Tabela 18 - Escala utilizada para avaliação do controle da Emilia Sonchifolia após aplicação dos tratamentos (ALAM, 1974).

\begin{tabular}{ccc}
\hline Notas & $\begin{array}{c}\text { Classe de porcentagem } \\
(\%)\end{array}$ & Conceito de controle \\
\hline 1 & $0-40$ & Nenhum/pobre \\
2 & $41-60$ & Regular \\
3 & $61-70$ & Suficiente \\
4 & $71-80$ & Bom \\
5 & $81-90$ & Muito bom \\
6 & $91-100$ & Excelente \\
\hline
\end{tabular}

Fonte: ALAM,1974.

Com base nos sintomas observados (Figura 30), o tratamento na concentração de $200 \mathrm{~g}$ $\mathrm{L}^{-1}$ foi definido para as aplicações.

Figura 30 - Efeito do bioerbicida extraído das folhas do feijão-de-porco na concentração de $200 \mathrm{~g} \mathrm{~L}^{-1}$ na planta invasora Emilia sonchifolia. (1) sem aplicação, (2) 24 h após aplicação, (3) 5 dias após aplicação. As fotos 2 e 3 estão ampliadas para melhor visualização das injúrias.

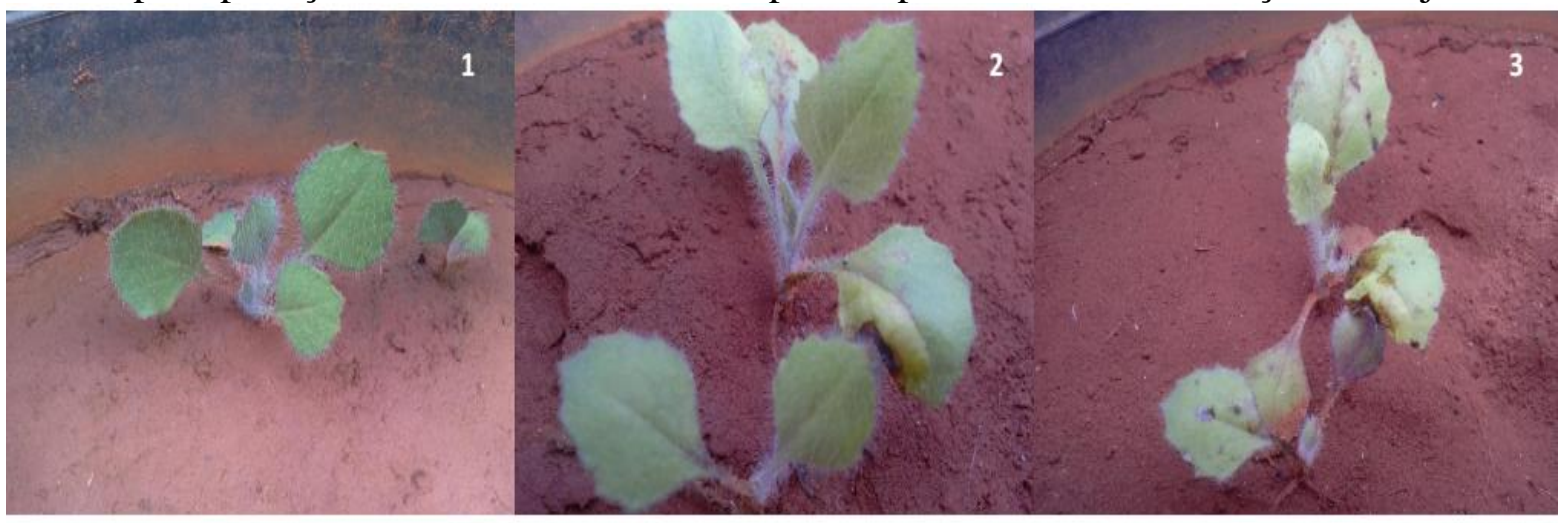

Fonte: Autoria própria.

No $5^{\circ}$ dia após aplicação, a planta apresentava manchas na cor marrom bem acentuadas e uma maior descoloração das folhas. Nos dias seguintes, a murcha da planta foi continuada e a inibição do crescimento foi observada. Os sintomas de fitotoxicidade foram evoluindo proporcionalmente com as aplicações subsequentes. A partir da segunda aplicação (DAA30), os tratamentos apresentaram níveis regulares de injúria, até o DAA75 (última avaliação). Devido ao desenvolvimento diferenciado, ou seja, ao fato que nem todas as plantas no sistema estão no mesmo estágio de desenvolvimento, a ação do bioerbicida foi maior nas plantas em etapas iniciais de crescimento do que em plantas com um grau de maturação mais alto. A Tabela 
19 apresenta as medidas da altura das plantas e comprimento das folhas dos vasos submetidos à aplicação do bioerbicida e do vaso utilizado como referência, mostrando o desenvolvimento das plantas invasoras durante as etapas de aplicação do bioerbicida.

Consideramos que a avaliação biométrica das plantas seria menos subjetiva que a avaliação visual, de acordo com a escala de conceitos da SBCPD

Tabela 19 - Análise de variância (ANOVA) da altura e comprimento das folhas da planta invasoras (Emilia sonchifolia) sob aplicação do bioerbicida e no vaso referência.

\begin{tabular}{ccccc}
\hline $\begin{array}{c}\text { Período de } \\
\text { avaliação } \\
\text { (dias) }\end{array}$ & \multicolumn{2}{c}{$\begin{array}{c}\text { Altura da planta } \\
(\mathrm{cm})^{*}\end{array}$} & $\begin{array}{c}\text { Comprimento das folhas } \\
(\mathrm{cm})^{*}\end{array}$ \\
& $\begin{array}{c}\text { Sob aplicação } \\
\text { do bioerbicida }\end{array}$ & Vaso referência & $\begin{array}{c}\text { Sob aplicação } \\
\text { do bioerbicida }\end{array}$ & Vaso referência \\
\hline DAA15 & $5,28 \pm 0,24 \mathbf{a}$ & $6,04 \pm 0,28 \quad \mathbf{b}$ & $2,90 \pm 0,22 \mathbf{a}$ & $3,32 \pm 0,36 \mathbf{a}$ \\
DAA30 & $12,26 \pm 0,43 \mathbf{a}$ & $14,30 \pm 0,33 \mathbf{b}$ & $4,12 \pm 0,34 \mathbf{a}$ & $5,06 \pm 0,68 \mathbf{b}$ \\
DAA45 & $13,22 \pm 0,45 \mathbf{a}$ & $16,40 \pm 0,68 \mathbf{b}$ & $5,22 \pm 0,13 \mathbf{a}$ & $6,64 \pm 0,52 \mathbf{b}$ \\
DAA60 & $14,08 \pm 0,24 \mathbf{a}$ & $17,12 \pm 0,50 \mathbf{b}$ & $5,86 \pm 0,39 \mathbf{a}$ & $8,10 \pm 0,29 \mathbf{b}$ \\
DAA75 & $14,30 \pm 0,33 \mathbf{a}$ & $18,76 \pm 0,46 \mathbf{b}$ & $6,50 \pm 0,34 \mathbf{a}$ & $9,46 \pm 0,58 \mathbf{b}$
\end{tabular}

*Média de 5 plantas. Médias seguidas pela mesma letra na linha, não diferem estatisticamente entre si, pelo teste Tukey.

As plantas invasoras submetidas à ação do bioerbicida chegaram a uma altura máxima de aproximadamente $14 \mathrm{~cm}$. A planta invasora presente no vaso referência conseguiu atingir aproximadamente $18 \mathrm{~cm}$, que, em geral, apresentou um melhor desenvolvimento, conforme mostrado na Tabela 19.

As plantas do vaso referência apresentaram, aparentemente, um melhor desenvolvimento quanto à biometria.

Estatisticamente a biometria das plantas do vaso referência foi diferente da do vaso sob aplicação de bioerbicida, apontando, assim, para a ideia da ação inibitória do bioerbicida em estudo. Quanto à biometria das folhas, foi verificado que apesar da injúria causada inicialmente (24 h após aplicação), o desenvolvimento da planta invasora só foi prejudicado após uma segunda aplicação do bioerbicida. A Figura 31 mostra o desenvolvimento da planta invasora ao longo do experimento 
Figura 31 - Desenvolvimento da planta invasora Emilia sonchifolia.

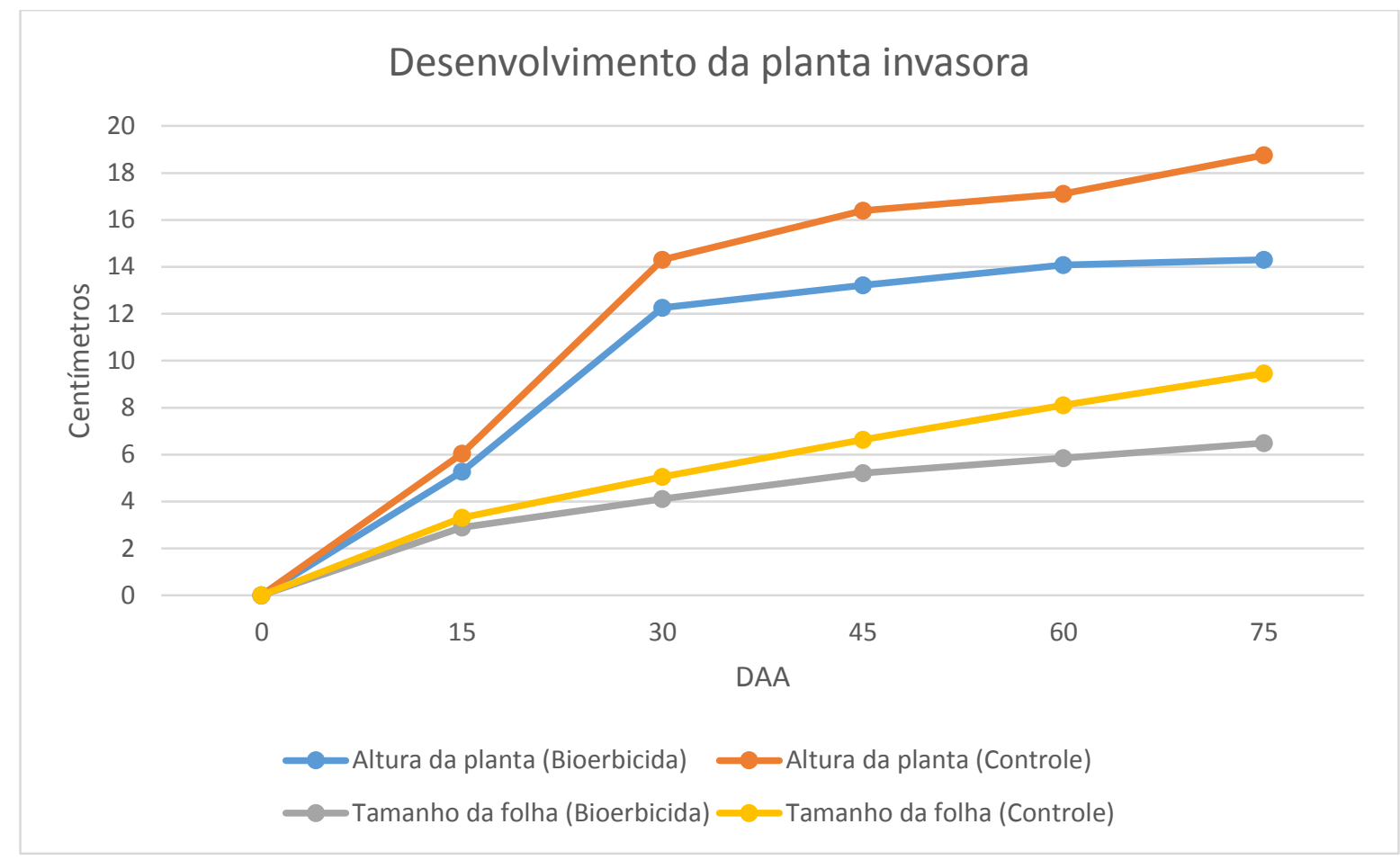

O efeito inibitório dos extratos aquosos age como estresse bioquímico na planta. Os aleloquímicos presentes nos extratos podem causar um efeito prejudicial ou benéfico nas plantas. Essas substâncias podem interferir na germinação e no desenvolvimento de espécies vegetais próximas (FERREIRA et al., 2010). Depois de liberados no ambiente por meio de diversas rotas, os aleloquímicos podem causar efeitos diretos e indiretos sobre as plantas. Os efeitos indiretos constituem qualquer alteração nas características nutricionais do solo, como também, nas populações, atividades de micro-organismos e insetos. Os efeitos diretos compreendem as alterações no crescimento e metabolismo vegetal, englobando alterações em nível celular, fitormonal, fotossintético e respiratório, consequentemente, dificultando a absorção de nutrientes e água, entre outros (MARASHIM-SILVA; AQUILA, 2006). A Figura 32 mostra o vaso utilizado como referência nos experimentos com a planta invasora Emilia sonchifolia e a soja. 
Figura 32 - Vaso referência utilizado nos experimentos com a planta Emilia sonchifolia (à esquerda) e a soja (à direita).

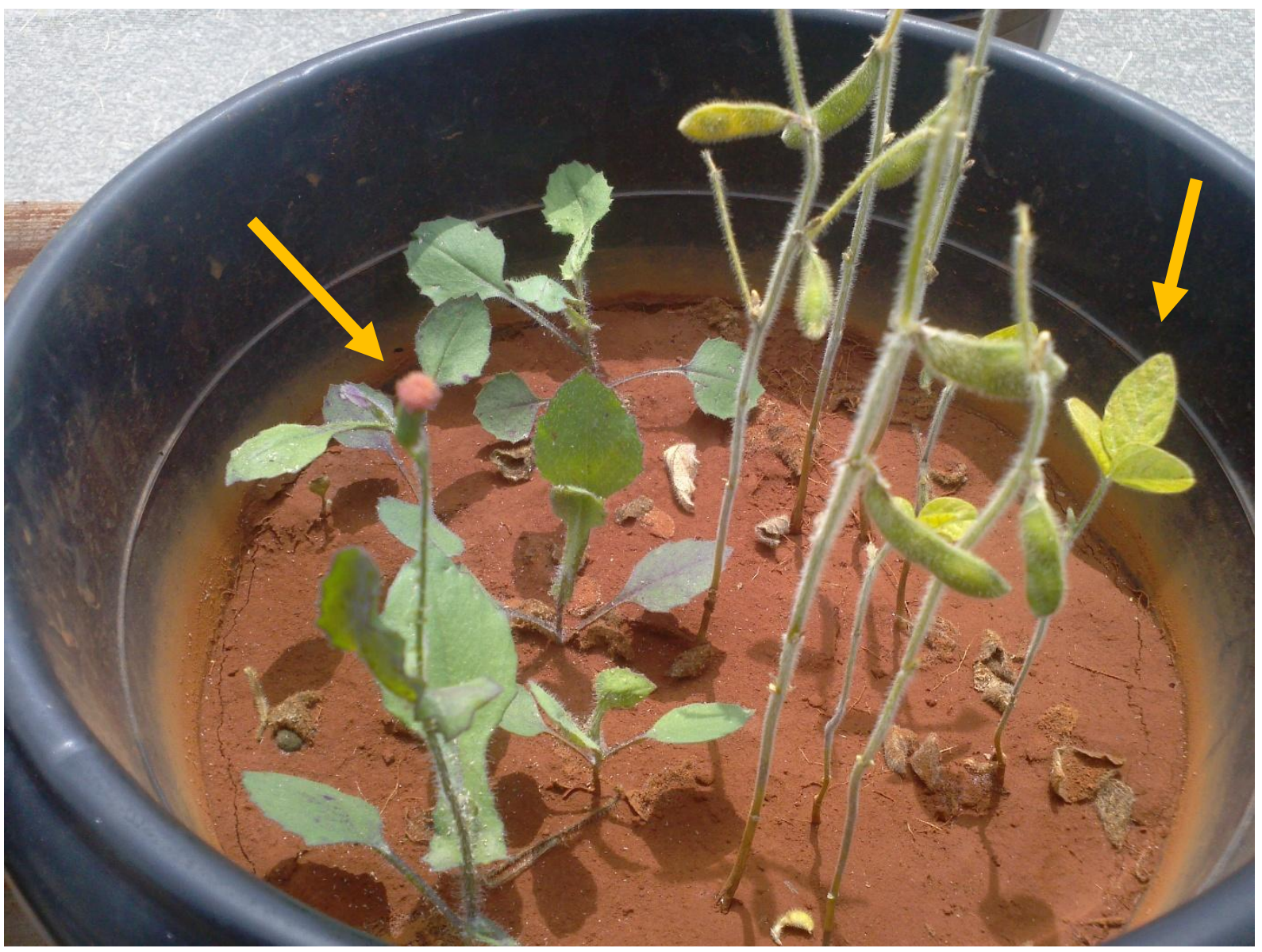

Fonte: Autoria própria.

O vaso referência não foi sujeito às aplicações do bioerbicida, a ele foram atribuídas as condições comparativas em relação às plantas de soja e as invasoras submetidas à ação dos extratos. $\mathrm{O}$ vaso referência apresentou ambas as culturas bem desenvolvidas. Como pode ser visto na Figura 32, as setas mostram a planta invasora com as flores vermelhas, características do bom desenvolvimento da espécie. A planta da soja convencional apresentava-se no estágio de formação das vagens, mas aparentemente, deficiente em nitrogênio devido à competição por nutrientes (alelopatia) pela planta invasora presente. Características como o amarelecimento e a queda natural das folhas (desfolha) são sintomas visuais da deficiência nutricional da planta. Na Tabela 20 estão os valores médios do controle da planta invasora de acordo com os conceitos de ALAM, quando submetidas à ação do extrato contendo o bioerbicida. 
Tabela 20 - Valores médios da porcentagem de controle da Emilia sonchifolia tratadas com 3,0 $\mathrm{mL}$ dos extratos aquosos da Canavalia ensiformis na concentração de $200 \mathrm{~g} \mathrm{~L}^{-1}$.

\begin{tabular}{ccc}
\hline $\begin{array}{c}\text { Período de } \\
\text { avaliação } \\
\text { (dias) }\end{array}$ & $\begin{array}{c}\text { Média } \\
(\%)\end{array}$ & $\begin{array}{c}\text { Conceito de } \\
\text { ALAM } \\
(1974)\end{array}$ \\
\hline DAA15 & 65,00 & $\begin{array}{c}\text { Suficiente } \\
\text { DAA30 }\end{array}$ \\
74,00 & Bom \\
DAA45 & 74,00 & Bom \\
DAA60 & 74,00 & Bom \\
DAA75 & 90,00 & Muito bom \\
\hline
\end{tabular}

$\mathrm{Na}$ avaliação referente ao DAA15, o tratamento foi considerado suficiente, tendo como base apenas as injúrias causadas na planta e nos dias seguintes de avaliação (DAA30, DAA45 e DAA60) foi considerado bom, sendo que as características da biometria e os sinais de fitotoxicidade nas folhas mantiveram uma regularidade, mesmo sujeitos a novas aplicações dos extratos aquosos. Na avaliação referente ao DAA75, ação do tratamento foi considerado muito bom, tendo em vista uma quinta aplicação cumulativa dos extratos, as avaliações biométricas da planta invasora ao longo do experimento e as condições que o sistema apresentava, ou seja, com plantas invasoras secas e/ou mortas.

O tratamento testado mostrou uma porcentagem de controle efetivo (74-90\%) no período final do experimento, tendo nota 5 e conceito muito bom pela escala de ALAM (1974). $\mathrm{Na}$ Tabela 21 estão dispostos os conceitos das avaliações visuais para as 4 concentrações utilizadas.

Tabela 21 - Resultado das avaliações visuais dos tratamentos sobre a Emilia sonchifolia utilizando-se uma dose única de 3,0 mL do extrato contendo o bioerbicida, segundo a escala de conceitos da SBCPD.

\begin{tabular}{cccccc}
\hline Tratamento & \multicolumn{5}{c}{ Períodos de avaliação (DAA) } \\
\hline g L $^{-1}$ & 15 & 30 & 45 & 60 & 75 \\
100 & a & - & - & - & - \\
125 & a & - & - & - & - \\
150 & a & - & - & - & - \\
200 & c & d & d & d & e
\end{tabular}

(a) Sem injúria, (b) injúria leve, (c) injúria moderada, (d) injúria severa e (e) destruição. 
A aplicação do bioerbicida no tempo zero foi realizada após o surgimento de pelo menos 4 a 7 folhas definitivas das plantas invasoras, aproximadamente 31 dias após o plantio das sementes. Das concentrações preparadas, as injúrias surgiram com uso do bioerbicida na concentração de $200 \mathrm{~g} \mathrm{~L}^{-1}$, como já mencionado, apresentando injúria considerada moderada aos DAA15, severa do DAA30 ao DAA60 e controle total (destruição/morte) na etapa final de avaliação ao DAA75.

As concentrações preparadas $\left(100,125,150\right.$ e $\left.200 \mathrm{~g} \mathrm{~L}^{-1}\right)$ também foram testadas na cultura de soja convencional. Inicialmente foi testado o extrato na concentração de $100 \mathrm{~g} \mathrm{~L}^{-1}$, no volume inicial de 1,5 mL por planta. A aplicação e ação dos extratos foram suficientes para causar alterações visíveis aproximadamente 24 h após aplicação (Figura 33).

Figura 33 - Sintoma de fitotoxicidade causada pela ação de $1,5 \mathrm{~mL}$ do extrato contendo o bioerbicida nas folhas da soja, $24 \mathrm{~h}$ após aplicação, em concentração de $100 \mathrm{~g} \mathrm{~L}^{-1}$.

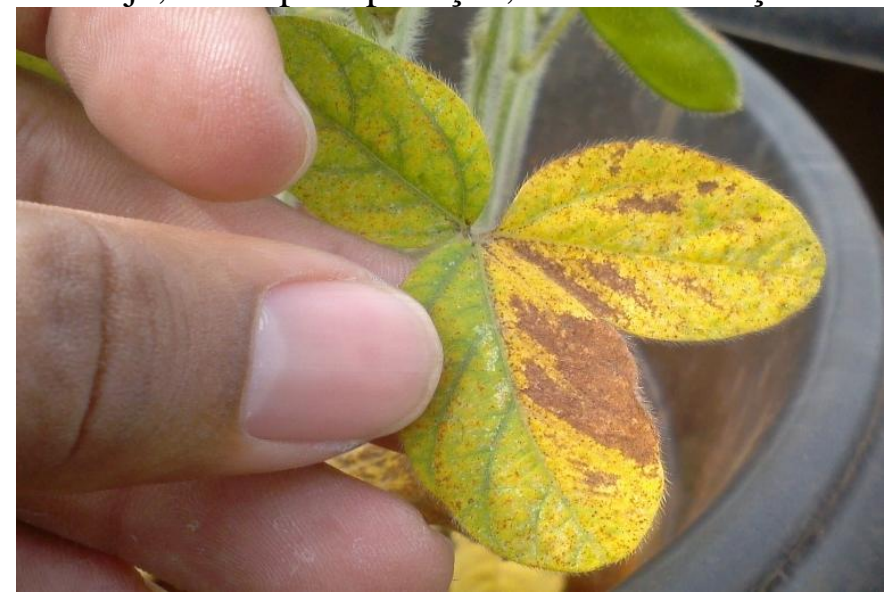

Fonte: Autoria própria.

Como resposta às aplicações, notou-se que há uma rápida ação dos extratos na soja, com alteração visual das folhas, que se tornam amareladas, com algumas manchas de cor marrom que se estendem por toda a área da folha da planta, provocando queda das folhas, mas mantendo o caule intacto, o que favorece a recuperação da planta e o seu desenvolvimento subsequente (Figura 34). Assim, a aplicação do bioerbicida diretamente na soja foi interrompida, acompanhando-se o desenvolvimento da soja até o $35^{\circ}$ dia. Convém mencionar que o julgamento final quanto à seletividade, ou não, de um tratamento herbicida a uma determinada cultura, deve ser feito a partir dos dados de produtividade, mesmo que não sejam verificados sintomas visuais de intoxicação. 
Figura 34 - Plantas de soja em desenvolvimento 35 dias após aplicação do bioerbicida, depois de interrompida a aplicação direta de $1,5 \mathrm{~mL}$ do extrato contendo o bioerbicida na concentração de $100 \mathrm{~g} \mathrm{~L}^{-1}$ em suas folhas.

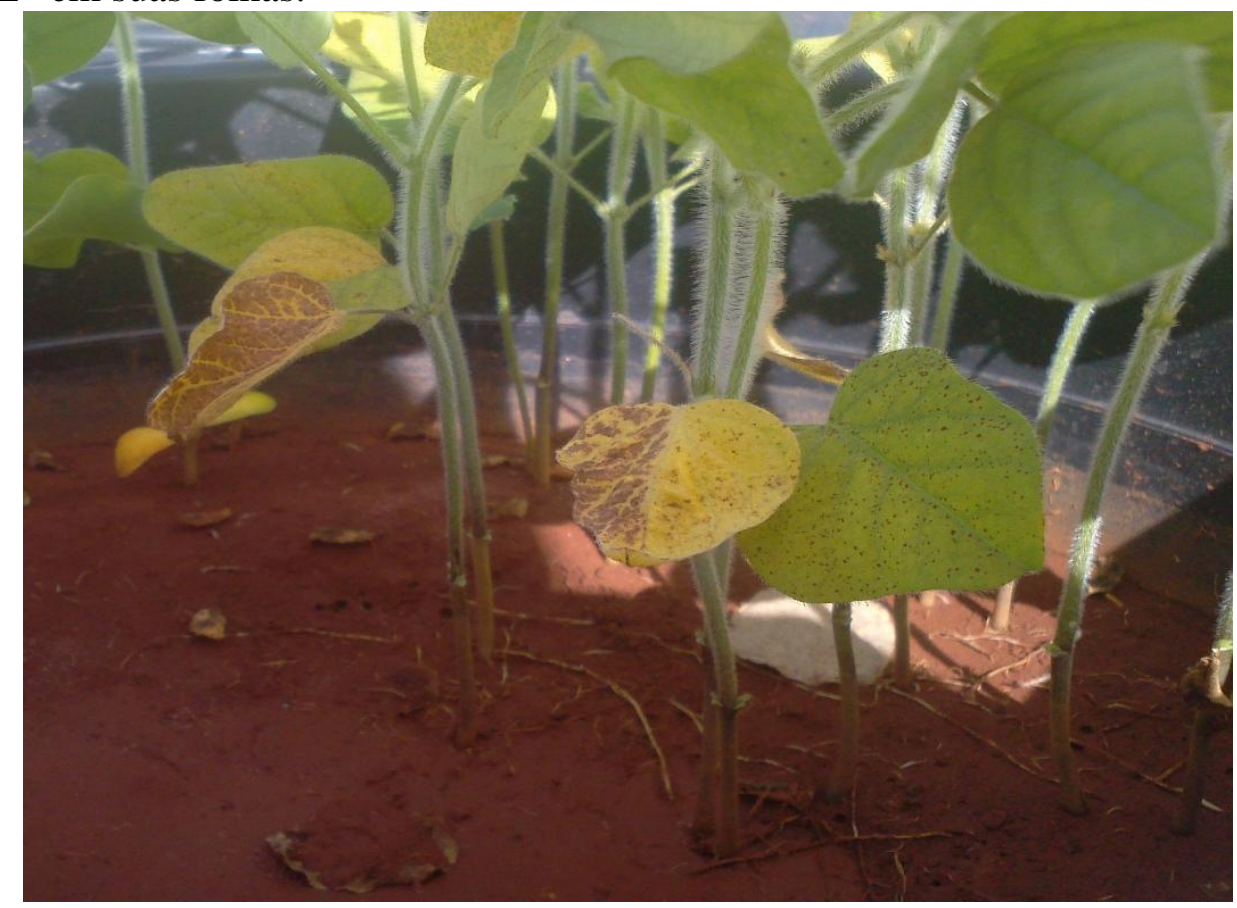

Fonte: Autoria própria.

Ensaios que visam avaliar a seletividade, normalmente são de difícil execução, já que uma ou mais plantas invasoras devem ser controladas e a cultura de interesse deve ser conduzida por um ciclo completo. Assim, os extratos aqui testados, devem ser utilizados em pósemergência, fazendo-se aplicações diretamente na planta invasora que se quer combater.

Logo, o extrato aquoso contendo os compostos com atividade bioerbicida não foi seletivo, causando injúria na plantação de soja convencional.

\subsection{Caracterização química das amostras do solo sob cultivo da Emilia sonchifolia}

As amostras de solo utilizadas sob diferentes cultivos, as amostras do solo referência e as amostras após as etapas de aplicação do bioerbicida, foram coletadas e levadas para o laboratório, de modo a avaliar possíveis alterações nas características desse solo. Nas Tabelas 22 e 23 apresenta-se a caracterização química e a composição mineral do solo utilizado no cultivo da soja e das plantas invasoras. 
Tabela 22 - Caracterização química do solo em estudo antes da implantação do experimento.

\begin{tabular}{cccccccccc}
$\begin{array}{c}\mathrm{pH} \\
\text { (água) }\end{array}$ & $\begin{array}{c}\mathrm{pH} \\
\left(\mathrm{CaCl}_{2}\right)\end{array}$ & $\begin{array}{c}\mathrm{H}+\mathrm{Al} \\
\left(\mathrm{cmol}_{\mathrm{c}} \mathrm{kg}^{-1}\right)\end{array}$ & $\begin{array}{c}\mathrm{K} \\
\left(\mathrm{mg} \mathrm{dm}^{-3}\right)\end{array}$ & $\begin{array}{c}\mathrm{Ca} \\
\left(\mathrm{cmol} \mathrm{dm}^{-3}\right)\end{array}$ & $\begin{array}{c}\mathrm{CTC} \\
\left(\mathrm{mmol}_{\mathrm{c} \mathrm{kg}}{ }^{-1}\right)\end{array}$ & $\begin{array}{l}\mathrm{MO} \\
\left(\mathrm{g} \mathrm{kg}^{-1}\right)\end{array}$ & $\begin{array}{c}\mathrm{N} \\
\left(\mathrm{mg} \mathrm{kg}^{-1}\right)\end{array}$ \\
\hline 5,27 & 5,14 & 0,11 & 2,5 & 0,08 & 25,69 & 73,63 & 8,09 & 4,70 & 5677,6
\end{tabular}

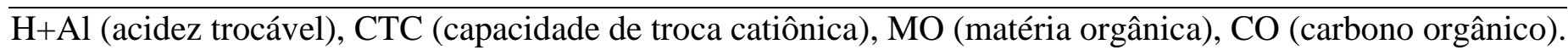

Tabela 23 - Caracterização física do solo utilizado.

\begin{tabular}{ccccccccc}
\hline $\begin{array}{c}\text { Argila } \\
(\%)\end{array}$ & $\begin{array}{c}\text { Silte } \\
(\%)\end{array}$ & $\begin{array}{c}\text { Areia } \\
\text { fina } \\
(\%)\end{array}$ & $\begin{array}{c}\text { Areia } \\
\text { média } \\
(\%)\end{array}$ & $\begin{array}{c}\text { Areia } \\
\text { grossa } \\
(\%)\end{array}$ & $\begin{array}{c}\text { Pedr. } \\
\text { Fino } \\
(\%)\end{array}$ & $\begin{array}{c}\text { Pedr. } \\
\text { Médio } \\
(\%)\end{array}$ & $\begin{array}{c}\text { Pedr. } \\
\text { Grosso } \\
(\%)\end{array}$ & Textura \\
\hline 58,7 & 29 & 11,0 & 1,0 & 0,3 & 0 & 0 & 0 & $\begin{array}{c}\text { Argilo- } \\
\text { siltosa }\end{array}$ \\
\hline
\end{tabular}

Pedr (pedregulho). 
A Figura 35 apresenta a curva de distribuição granulométrica do solo.

Figura 35 - Curva de distribuição granulométrica do solo antes do início dos experimentos em casa de vegetação.

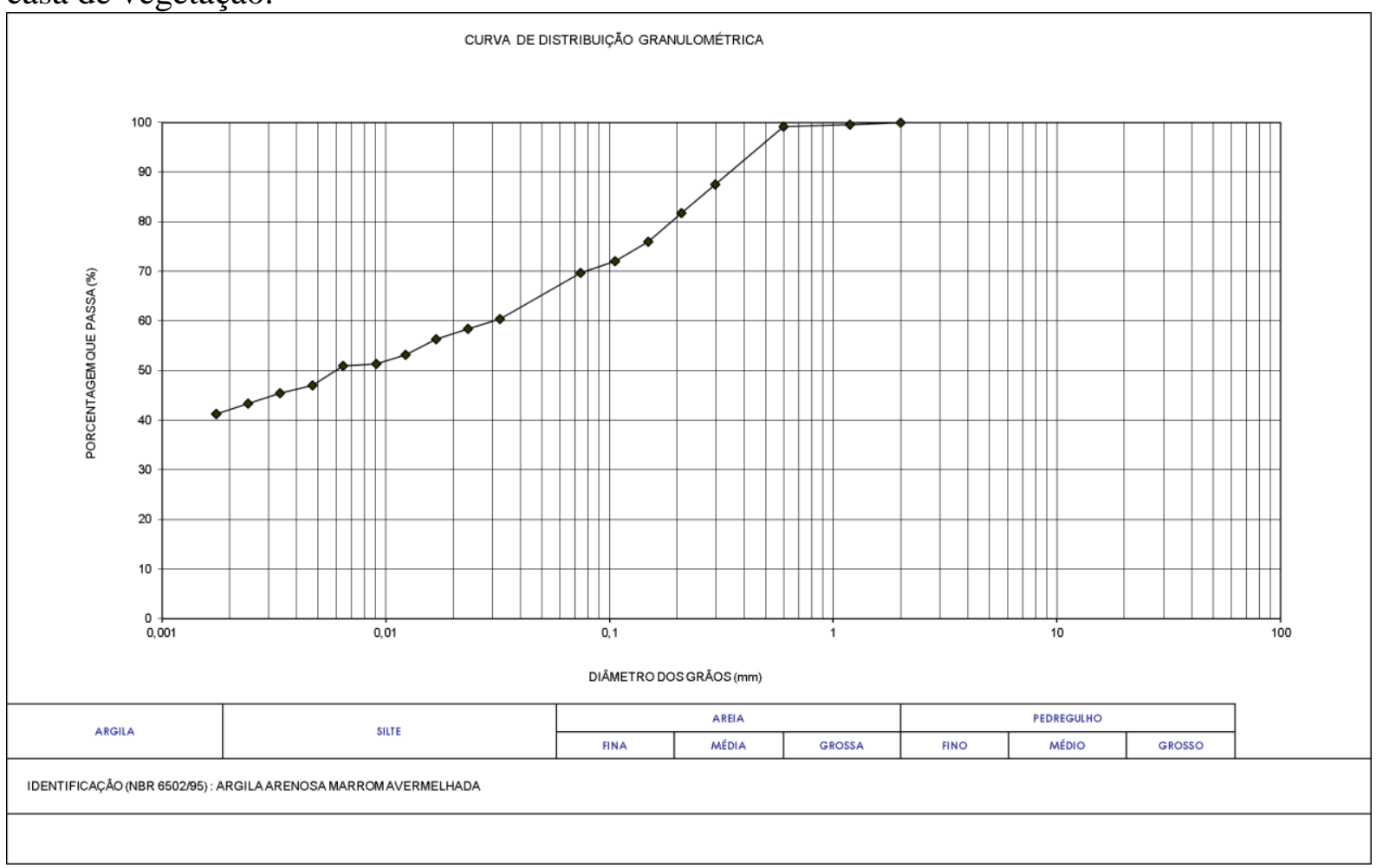

A Figura 36 mostra as médias de temperatura e precipitação ao longo do experimento.

Figura 36 - Média das temperaturas e precipitação durante o experimento com a planta invasora Emilia sonchifolia. Média t máxima (média das temperaturas máximas). Média t mínima (média das temperaturas mínimas).

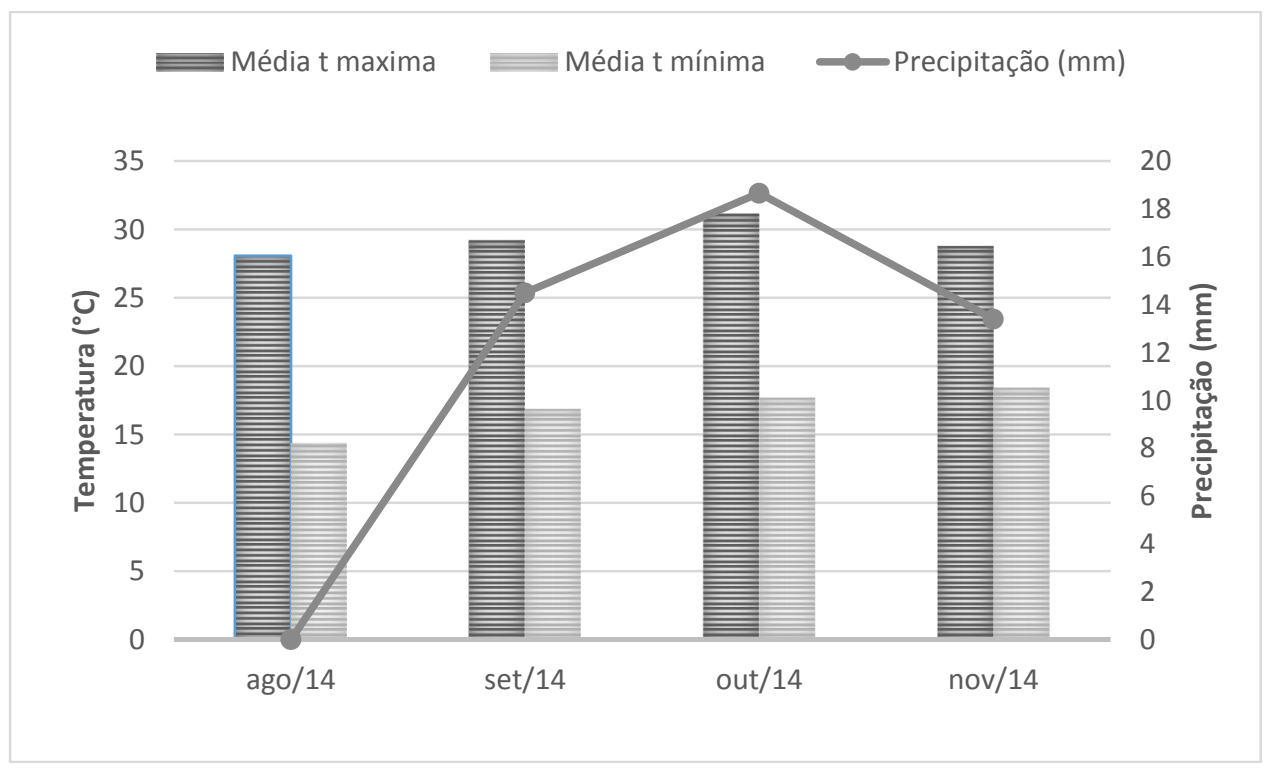


Pela Figura 36, nota-se que o experimento foi conduzido em um período de calor intenso, com temperaturas máximas próximas a $30^{\circ} \mathrm{C}$, com uma média de chuvas superior em outubro, em relação aos demais meses. Na Tabela 24 são apresentados os dados comparativos das características do solo e após 15 dias do início dos experimentos (tempo zero). 
Tabela 24 - Caracterização química inicial do solo e 15 dias após o início dos experimentos em casa de vegetação com a planta Emilia sonchifolia.

\begin{tabular}{ccccccccccc}
\hline & $\mathrm{pH}$ & $\mathrm{pH}$ & $\mathrm{H}+\mathrm{Al}$ & $\mathrm{K}$ & $\mathrm{P}$ disp & $\mathrm{Ca}$ & $\mathrm{N} \mathrm{Total}$ & $\mathrm{CTC}$ Total & $\mathrm{CO}$ & $\mathrm{MO}$ \\
& $\left(\mathrm{H}_{2} \mathrm{O}\right)$ & $\left(\mathrm{CaCl}_{2}\right)$ & & & & & & & & \\
\hline $\mathrm{Solo}^{1}$ & $5,27 \mathbf{a}$ & $5,14 \mathbf{a}$ & $0,11 \mathbf{a}$ & $2,50 \mathbf{a}$ & $0,08 \mathbf{a}$ & $25,69 \mathbf{a}$ & $5677,6 \mathbf{a}$ & $73,63 \mathbf{a}$ & $4,70 \mathbf{a}$ & $8,09 \mathbf{a}$ \\
$\mathrm{Solo}^{2}$ & $5,65 \mathbf{a}$ & $4,67 \mathbf{a}$ & $0,66 \mathbf{a}$ & $2,90 \mathbf{a}$ & $0,11 \mathbf{a}$ & $17,11 \mathbf{b}$ & $4442,3 \mathbf{b}$ & $32,09 \mathbf{b}$ & $5,06 \mathbf{a}$ & $8,73 \mathbf{a}$
\end{tabular}

${ }^{1}$ Solo. ${ }^{2}$ Solo analisado após 15 dias do início dos experimentos. Médias seguidas pela mesma letra na coluna não diferem significativamente entre si pelo teste de Tukey $(\mathrm{P}<0,05)$. 
A plantação das culturas no sistema alterou significativamente as características químicas do solo, dentre elas, o teor de nitrogênio, o de cálcio e a CTC podem ser destacados. O nitrogênio é fundamental para o desenvolvimento da cultura de soja e também de outras plantas, assim, um teor menor deste elemento pode estar relacionado a absorção de nutrientes pelas plantas envolvidas no experimento. A CTC representa a fertilidade do solo quanto à disponibilidade de nutrientes necessários às plantas (soja + planta invasora). O contato dos extratos no solo no intervalo de 15 dias, pode estar relacionado com a diminuição dos níveis de CTC assim como a incorporação das plantas no sistema (solo-plantas). É importante ressaltar que a aplicação dos extratos nas plantas invasoras ocasiona o contato direto destes extratos no solo. A seguir são apresentados os dados da análise do solo durante as etapas de aplicação e incorporação do bioerbicida.

\subsection{Análise do solo após aplicação do bioerbicida}

\subsection{1 pH}

A Figura 37 apresenta a análise do solo durante as etapas de aplicação e incorporação do bioerbicida em estudo. Foi determinado o pH do solo tanto em água como em solução de $\mathrm{CaCl}_{2}$. Pela similaridade dos valores, serão mostrados na Figura 40 apenas os valores de $\mathrm{pH}$ em solução de $\mathrm{CaCl}_{2}$.

Figura $37-\mathrm{pH}$ em $\mathrm{CaCl}_{2}$ do solo após incorporação do bioerbicida, na $1^{\mathrm{a}}, 2^{\mathrm{a}}, 3^{\mathrm{a}}, 4^{\mathrm{a}}$ e $5^{\mathrm{a}}$ aplicação. Médias seguidas pela mesma letra na coluna não diferem significativamente entre si pelo teste de Tukey $(\mathrm{P}<0,05)$.

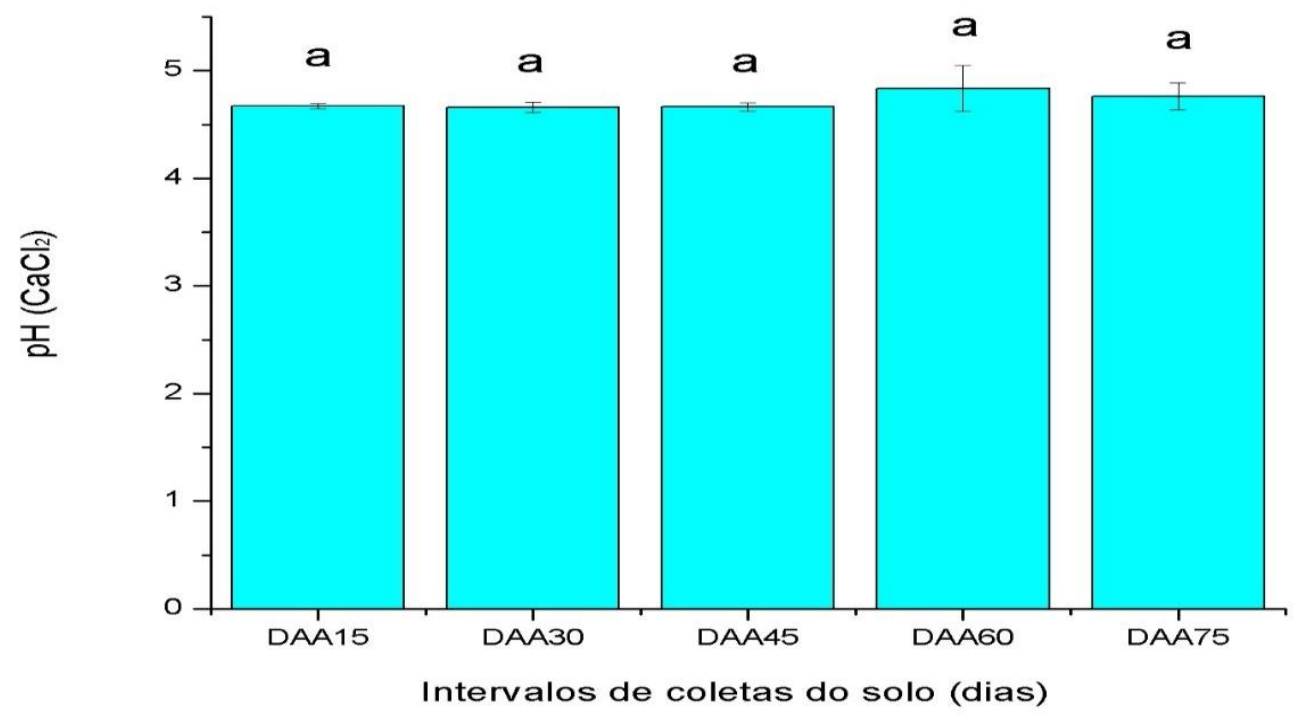


Os valores médios de $\mathrm{pH}$ (em água e em cloreto de cálcio) não apresentaram diferenças significativas durante todo o processo, desde a aplicação e incorporação do bioerbicida, compreendido dos 15 aos 75 dias do experimento. Vale ressaltar que a acidez dos solos caracteriza uma condição desfavorável para o desenvolvimento pleno de várias culturas agrícolas (MATOS et al., 2012). No caso da soja, pode-se inferir que o pH do solo utilizado no nosso experimento $(\leq 4,83)$ não foi um fator prejudicial ao desenvolvimento da cultura, sendo que este grão consegue se desenvolver em condições de estresse do solo. Caires et al (2008) avaliaram o comportamento da soja em solos ácidos, observando que a diminuição do $\mathrm{Al}^{3+}$ trocável em solo com calagem não altera a concentração do $\mathrm{Al}^{3+}$ nas raízes e nas folhas de soja, de forma geral a produção de grãos de soja não é influenciada pela calagem devido à baixa toxicidade do alumínio e também porque houve o crescimento radicular estimulado por condições de acidez no solo. Sabendo-se que os intervalos de avaliações (15-75 dias) correspondentes a $1^{\mathrm{a}}, 2^{\mathrm{a}}, 3^{\mathrm{a}}, 4^{\mathrm{a}}$ e $5^{\mathrm{a}}$ aplicação do bioerbicida, notou-se que um número maior de aplicações, dentro dos intervalos pré-estabelecidos, não contribuiu para o aumento da acidez do solo. Na Tabela 25 estão os dados médios e os desvios padrão encontrados.

Tabela 25 - Valores de pH do solo ao longo do experimento com a planta Emilia sonchifolia.

\begin{tabular}{lll}
\hline Coletas (dias) & $\mathrm{pH}$ (água) & $\mathrm{pH}\left(\mathrm{CaCl}_{2}\right)$ \\
\hline DAA15 & $5,65 \pm 0,05 \mathbf{a}$ & $4,67 \pm 0,02 \mathbf{a}$ \\
DAA30 & $5,53 \pm 0,10 \mathbf{a}$ & $4,66 \pm 0,05 \mathbf{a}$ \\
DAA45 & $5,58 \pm 0,19 \mathbf{a}$ & $4,66 \pm 0,04 \mathbf{a}$ \\
DAA60 & $5,63 \pm 0,28 \mathbf{a}$ & $4,83 \pm 0,21 \mathbf{a}$ \\
DAA75 & $5,80 \pm 0,29 \mathbf{a}$ & $4,76 \pm 0,12 \mathbf{a}$
\end{tabular}

$(\mathrm{n}=3)$. Médias seguidas pela mesma letra na coluna não diferem significativamente entre si pelo teste de Tukey $(\mathrm{P}<0,05)$.

\subsubsection{Cálcio e potássio}

A absorção de Ca é na forma $\mathrm{Ca}^{2+}$, sendo menor em presença de altas concentrações de $\mathrm{K}^{+}$e de $\mathrm{Mg}^{2+}$, no meio. O Ca é transportado no xilema, unidirecionalmente, sob controle metabólico. A maior parte do Ca na planta está em formas insolúveis em água ou adsorvido às proteínas (SFREDO, 2008).

O Ca mantém a integridade funcional da membrana celular. Na ausência deste nutriente, a membrana celular torna-se porosa, podendo perder íons já absorvidos e, também, absorver 
íns indesejáveis. Quando há carência de Ca, a germinação do pólen e o crescimento do tubo polínico são dificultados (SFREDO, 2008).

O Ca é um nutriente com baixa mobilidade no floema, com consequente aparecimento dos sintomas de deficiência nos tecidos novos das plantas. Na deficiência de cálcio, são afetados os pontos de crescimento, tanto da raiz como da parte aérea, os sintomas aparecem nas partes mais novas da planta, atrofiando o sistema radicular, matando a gema apical, retardando a emergência das folhas primárias que adquirem forma de taça (encarquilhamento) (SFREDO, 2008).

O potássio é absorvido como $\mathrm{K}^{+}$e assim transportado pelo xilema, de onde passa rapidamente para o floema. Cerca de $70 \%$ do $\mathrm{K}$ total encontram-se na forma iônica, livre na célula, onde podem ser retirados pela água. Os outros 30\% são adsorvidos às proteínas, das quais se libertam quando a planta envelhece. O K é um ativador enzimático, pois cerca de 60 enzimas requerem sua presença (SFREDO, 2008).

Apear do K não fazer parte dos compostos da planta, a concentração encontrada nela é alta (no caso da soja, cerca de 3\%). A baixa afinidade entre o $\mathrm{K}$ em relação a proteína

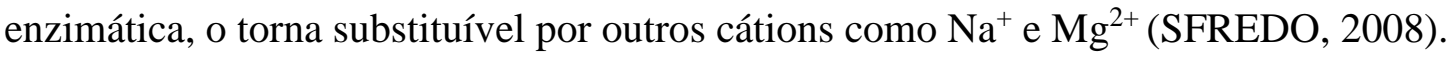

O K regula a abertura e o fechamento dos estômatos nas células-guarda e a turgidez (dilatação) do tecido, criando condições favoráveis para as reações da fotossíntese e outros processos metabólicos (SFREDO, 2008).

O K diminui a incidência de doenças na soja mais do que qualquer outro nutriente. Caracteriza-se por sua alta mobilidade nas plantas dentro das células, dos tecidos e no transporte a longas distâncias, das folhas e órgãos mais velhos para os mais novos e para os frutos em desenvolvimento. A deficiência de potássio causa clorose internerval, seguida de necrose nas bordas e ápice das folhas mais velhas, devido à formação da putrescina, que torna o aspecto de queimada por fogo nas plantas (SFREDO, 2008).

A Figura 38A-B e a Tabela 25 apresentam os teores de cálcio e potássio no solo durante as etapas de aplicação e incorporação do bioerbicida em estudo. 
Figura 38 - Teor de cálcio (A), teor de potássio (B) do solo após incorporação do bioerbicida, na $1^{\mathrm{a}}, 2^{\mathrm{a}}, 3^{\mathrm{a}}, 4^{\mathrm{a}}$ e $5^{\mathrm{a}}$ aplicação. Médias seguidas pela mesma letra na coluna não diferem significativamente entre si pelo teste de Tukey $(\mathrm{P}<0,05)$.
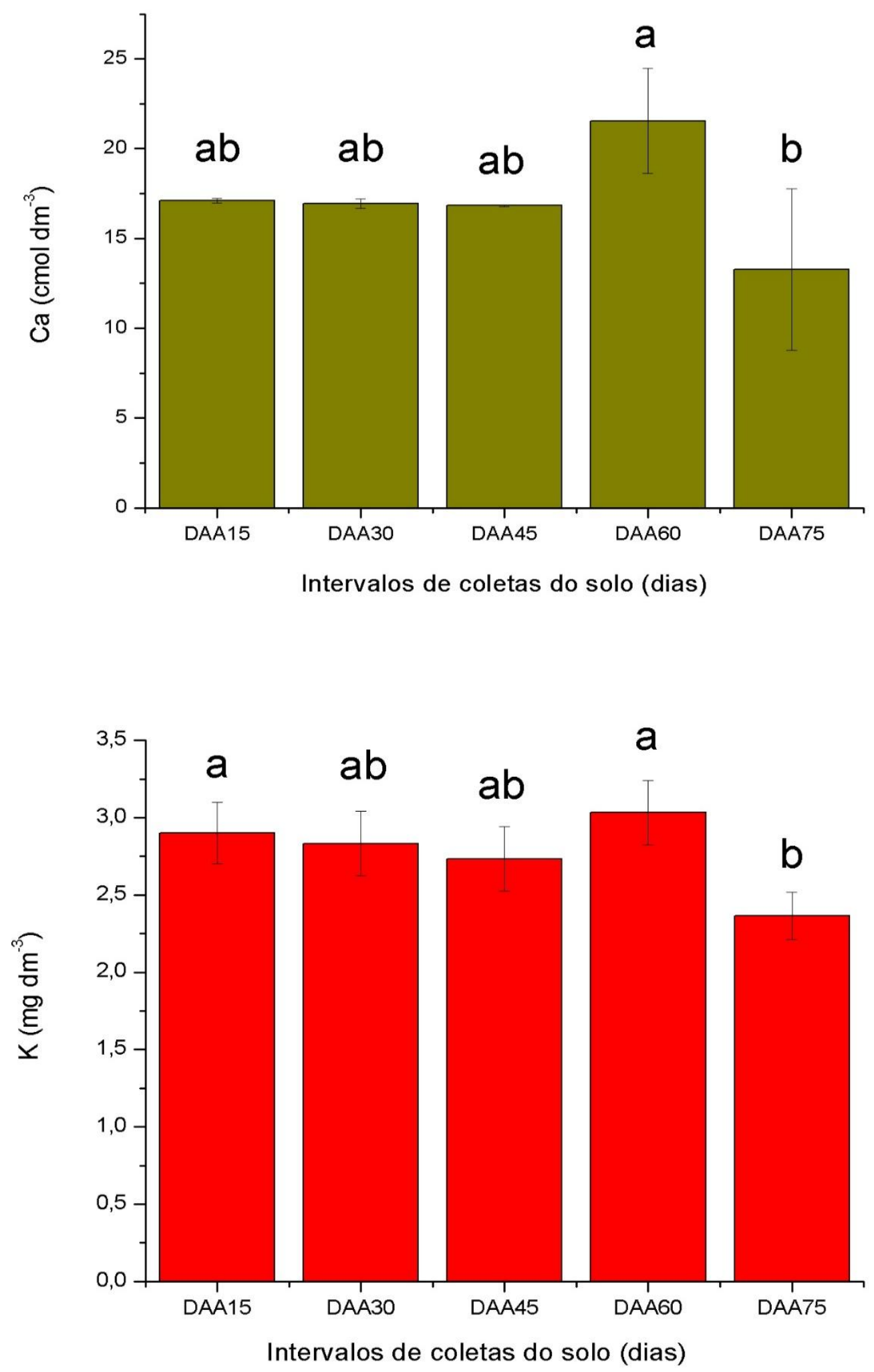

(B) 
O desenvolvimento e desempenho produtivo das culturas agrícolas em solos ácidos podem ser limitados em virtude da deficiência de cálcio e potássio. Entretanto, o uso de corretivos da acidez do solo ou o uso de técnicas de calagem do solo com corretivos com baixo teor de magnésio pode restringir efeito benéficos no solo, provocando um desbalanço nutricional nas plantas (MEDEIROS et al., 2008). No nosso experimento, não foram observados sintomas da deficiência nutricional destes nutrientes na cultura da soja, sendo que a mesma conseguiu completar seu ciclo durante o experimento.

A avaliação dos macronutrientes $\mathrm{Ca}$ e $\mathrm{K}$, em geral, não apresentou diferenças significativas ao longo do experimento. Pela Figura 37A podemos inferir que os níveis de cálcio mantiveram-se constante ao longo do experimento, apresentando diferença estatística apenas no DAA75, provavelmente devido ao início de um novo ciclo deste nutriente no sistema. Uma hipótese para as variações nos níveis de cálcio no solo pode ser atribuída à frequência com que o sistema era regado, ou seja, em períodos de temperatura mais elevadas, o umedecimento do solo era maior. Em ambos os casos (figuras 37A e 37B), os resultados observados no tempo final de análise do solo (DAA75) apresentaram valores médios menores e estatisticamente diferentes em relação à etapa anterior, dando a ideia de um consumo maior destes nutrientes em uma etapa em que o sistema continha plantas invasoras mortas ou em decadência e o desenvolvimento de novas plantas de soja.

Mesmo estando em níveis baixos de $\mathrm{Ca}^{2+}$ e $\mathrm{K}^{+}$, o solo apresentou o mesmo comportamento em relação aos outros nutrientes avaliados, ou seja, a análise do solo aos DAA60 apresentou valores numericamente maiores que os determinados nas etapas anteriores. Na Tabela 26 estão os desvios padrão encontrados para os teores de cálcio e potássio no solo ao longo do experimento.

Tabela 26 - Teores de cálcio e potássio no solo ao longo do experimento com a planta Emilia sonchifolia.

\begin{tabular}{lll}
\hline $\begin{array}{l}\text { Coletas } \\
(\text { dias })\end{array}$ & Cálcio $\left(\mathrm{cmol} \mathrm{dm}^{-3}\right)$ & Potássio $\left(\mathrm{mg} \mathrm{dm}^{-3}\right)$ \\
\hline DAA15 & $17,11 \pm 0,12 \mathbf{a b}$ & $2,90 \pm 0,20 \mathbf{a}$ \\
DAA30 & $16,94 \pm 0,25 \mathbf{a b}$ & $2,83 \pm 0,21 \mathbf{a b}$ \\
DAA45 & $16,83 \pm 0,03 \mathbf{a b}$ & $2,73 \pm 0,21 \mathbf{a b}$ \\
DAA60 & $21,54 \pm 2,92 \mathbf{a}$ & $3,03 \pm 0,21 \mathbf{a}$ \\
DAA75 & $13,27 \pm 4,49 \mathbf{b}$ & $2,36 \pm 0,15 \mathbf{b}$
\end{tabular}

$(\mathrm{n}=3)$. Médias seguidas pela mesma letra na coluna não diferem significativamente entre si pelo teste de Tukey $(\mathrm{P}<0,05)$. 
Pelos resultados, nota-se que os níveis de cálcio e potássio na etapa final do experimento (DAA75) foram menores em relação aos do início do experimento, indicando uma possível absorção por parte das plantas remanescentes. Logo, a pequena diferença nos teores de cálcio e potássio não têm relação direta com o acúmulo dos extratos no solo.

\subsubsection{Fósforo disponível}

$\mathrm{O}$ fósforo é absorvido predominantemente na forma de $\mathrm{H}_{2} \mathrm{PO}_{4}{ }^{-}$. $\mathrm{O}$ ácido fosfórico, $\mathrm{H}_{3} \mathrm{PO}_{4}$, dissocia-se em três espécies iônicas $\mathrm{H}_{2} \mathrm{PO}_{4}^{-}, \mathrm{HPO}_{4}{ }^{2-}$ e $\mathrm{PO}_{4}{ }^{3-}$. A primeira é a forma predominante na faixa de $\mathrm{pH}$ 4,0 a 8,0 na qual vivem a maioria das plantas (SFREDO, 2008).

O P absorvido na forma mineral é rapidamente incorporado aos compostos orgânicos, pois $80 \%$ são encontrados como fosfohexases e difosfato de uridina, logo após a absorção, a qual é fortemente influenciada pela concentração de $\mathrm{Mg}^{2+}$ no meio que exerce efeito sinérgico (SFREDO, 2008).

$\mathrm{O}$ principal papel do $\mathrm{P}$ na fisiologia da planta é fornecer energia para reações biossintéticas e para o metabolismo vegetal. Havendo deficiência, o P não metabolizado no vacúolo pode sair da célula, sendo direcionado para órgãos mais novos da planta. Este nutriente é de fácil mobilidade na planta, assim, os sintomas de deficiência aparecem em primeiro lugar nas partes mais velhas, apresentando coloração verde-azulada e menor crescimento (SFREDO, 2008).

É um nutriente móvel no floema e, juntamente com o nitrogênio e o potássio, é o mais prontamente disponível para as outras partes da planta, em particular aos órgãos novos em crescimento, vegetativos ou reprodutivos, os quais são drenos preferenciais no desenvolvimento das plantas.

A Figura 39 apresenta os teores de fósforo disponível no solo durante as etapas de aplicação e incorporação do bioerbicida em estudo. 
Figura 39 - Fósforo disponível no solo após incorporação do bioerbicida, na $1^{\mathrm{a}}, 2^{\mathrm{a}}, 3^{\mathrm{a}}, 4^{\mathrm{a}}$ e $5^{\mathrm{a}}$ aplicação. Médias seguidas pela mesma letra na coluna não diferem significativamente entre si pelo teste de Tukey $(\mathrm{P}<0,05)$.

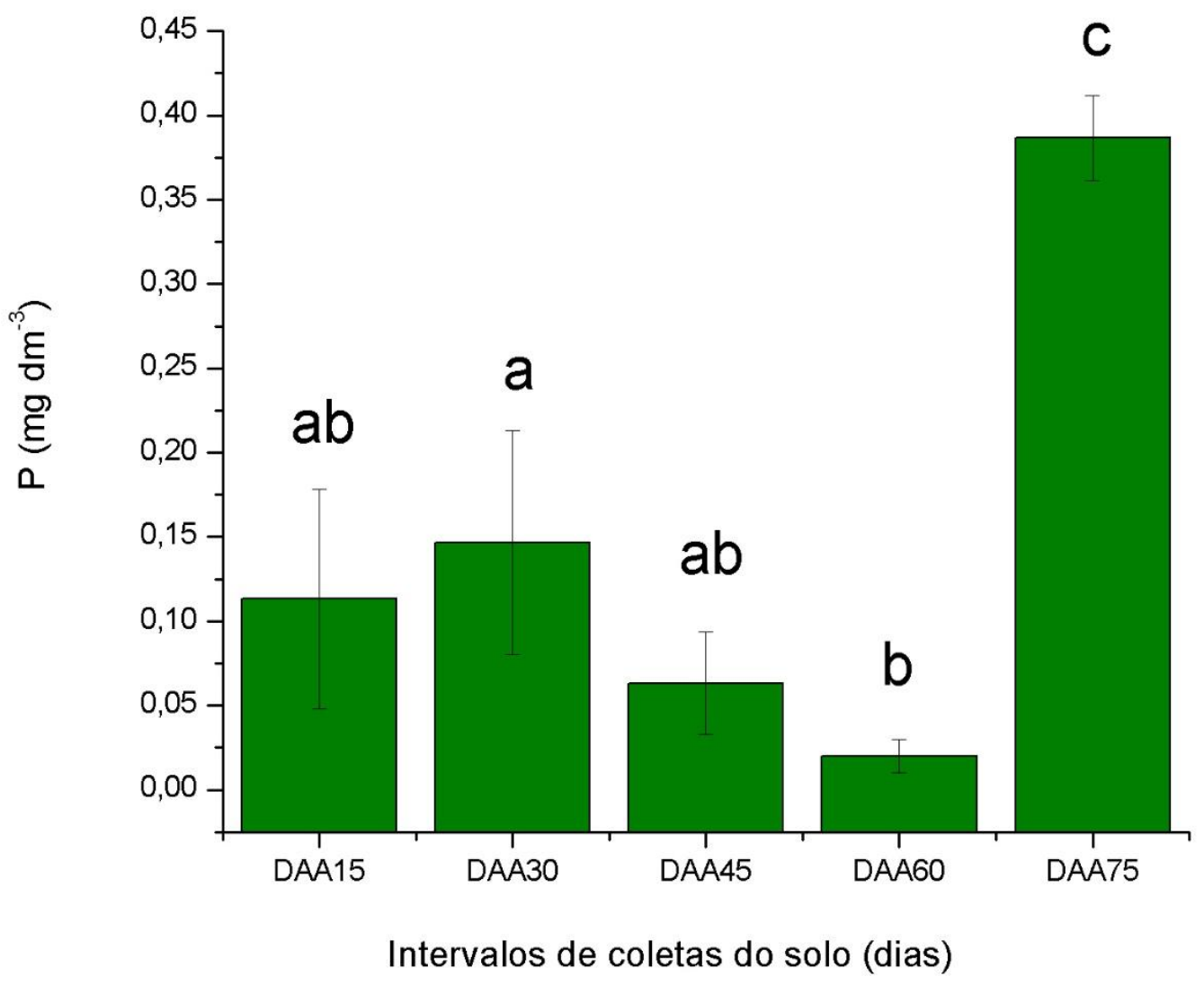

O fósforo contido no solo encontra-se na forma de minerais, com predomínio dos fosfatos, onde é liberado, em pequenas quantidades, para a solução do solo por meio do intemperismo. O fósforo total na maioria dos solos é relativamente grande, entretanto, os processos geoquímicos e biológicos podem transformar os fosfatos naturais em formas estáveis, combinado com outros elementos como cálcio, ferro ou alumínio, formando compostos não assimiláveis pelas plantas. O fósforo pode ser imobilizado, quando na forma orgânica não assimilável pelas plantas, tornando-se disponível para a planta pela mineralização da matéria orgânica, ou adsorvido, que é a fração de fósforo presa ao complexo coloidal do solo tornandose disponível através de trocas com as raízes e assimilável, parte que se encontra diluída na solução do solo sendo de fácil absorção pelas plantas. O termo fósforo disponível é o somatório do fósforo adsorvido com o assimilável. É absorvido pelas plantas sob a forma de ânions $\mathrm{H}_{2} \mathrm{PO}_{4}{ }^{-}$ 
e $\mathrm{HPO}_{4}{ }^{2-}$ em solos ácidos, sendo um nutriente altamente dependente da acidez e umidade do solo (AGROLINK, 2016).

A disponibilidade do fósforo ao longo do experimento mostrou diferença estatística entre algumas coletas. Essas coletas referem-se aos tempos DAA15, 30, 45 e 60 compreendem as etapas de desenvolvimento das sementes, crescimento e estabelecimento das culturas no solo, assim sendo, neste intervalo, a interação deste elemento com as culturas está alta. Como já discutido anteriormente o intervalo entre o tempo de coleta DAA60 e DAA75 representa um novo ciclo de plantas no sistema e, portanto, o reestabelecimento de nutrientes. Nota-se que na análise do solo aos DAA75, os níveis de fósforo passam a ser estatisticamente diferentes dos períodos anteriores, apresentando níveis elevados em relação ao início do experimento.

Convém mencionar que a disponibilidade de nutrientes no solo depende da CTC. Solos argilosos têm maior capacidade de adsorção, o que interfere na disponibilidade de nutrientes retidos no complexo coloidal do solo até serem assimilados, o que nesse caso, torna o fósforo um elemento difícil de se tornar disponível (AGROLINK, 2016).

Na Tabela 27 estão os teores de fósforo disponível no solo ao longo do experimento.

Tabela 27 - Teores de fósforo no solo ao longo do experimento com planta Emilia sonchifolia. Coletas (dias) Fósforo

\begin{tabular}{ll} 
& $\left(\mathrm{mg} \mathrm{dm}^{-3}\right)$ \\
\hline DAA15 & $0,11 \pm 0,06 \mathbf{a b}$ \\
DAA30 & $0,14 \pm 0,07 \mathbf{a}$ \\
DAA45 & $0,06 \pm 0,03 \mathbf{a b}$ \\
DAA60 & $0,02 \pm 0,01 \mathbf{b}$ \\
DAA75 & $0,38 \pm 0,02 \mathbf{c}$
\end{tabular}

$(\mathrm{n}=3)$. Médias seguidas pela mesma letra na coluna não diferem significativamente entre si pelo teste de Tukey $(\mathrm{P}<0,05)$.

Pelos valores determinados de fósforo no solo, pode-se observar que os níveis deste elemento diminuíram ao longo do experimento, tornando-se novamente disponíveis no solo aos DAA75, etapa que representa o reestabelecimento de nutrientes, a morte das plantas invasoras e um novo ciclo das plantas de soja no sistema. Logo, as variações nos teores de fósforo disponível não estão diretamente ligadas ao acúmulo dos extratos no solo. 


\subsubsection{Nitrogênio}

O N pode ser absorvido como amônio e nitrato. A forma predominante é a de nitrato e, quando isso acontece, $\mathrm{o}_{\mathrm{NO}_{3}}^{-}$deve ser reduzido a $\mathrm{NH}_{4}{ }^{+}$para o $\mathrm{N}$ ser transformado em aminoácidos e proteínas. Nas leguminosas, contudo, o nitrogênio atmosférico é fixado simbioticamente em amônia nos nódulos radiculares e, transportado como íon amônio. Para uma eficiente fixação biológica, há a necessidade da presença de molibdênio e cobalto (SFREDO, 2008).

O N é constituinte de aminoácidos, nucleotídeos e coenzimas. A pequena fração, presente como $\mathrm{NO}_{3}{ }^{-} \mathrm{ou} \mathrm{NH}_{4}{ }^{+}$tem como função ativar enzimas. Cerca de $90 \%$ do $\mathrm{N}$ total da planta encontra-se na forma orgânica (aminoácidos livres, proteínas, aminas, purinas, piridinas, ácidos nucléicos, vitaminas etc). É um nutriente de bastante mobilidade no floema, sua ausência provoca sintomas de deficiência, inicialmente, nas partes mais velhas da planta. Dentre os sintomas estão a clorose total, seguida de necrose (devido à diminuição da produção da clorofila) (SFREDO, 2008). A Figura 40 apresenta a concentração de nitrogênio no solo durante as etapas de aplicação e incorporação do bioerbicida em estudo.

Figura 40 - Nitrogênio total no solo após incorporação do bioerbicida, na $1^{\mathrm{a}}, 2^{\mathrm{a}}, 3^{\mathrm{a}}, 4^{\mathrm{a}}$ e $5^{\mathrm{a}}$ aplicação. Médias seguidas pela mesma letra na coluna não diferem significativamente entre si pelo teste de Tukey $(\mathrm{P}<0,05)$.

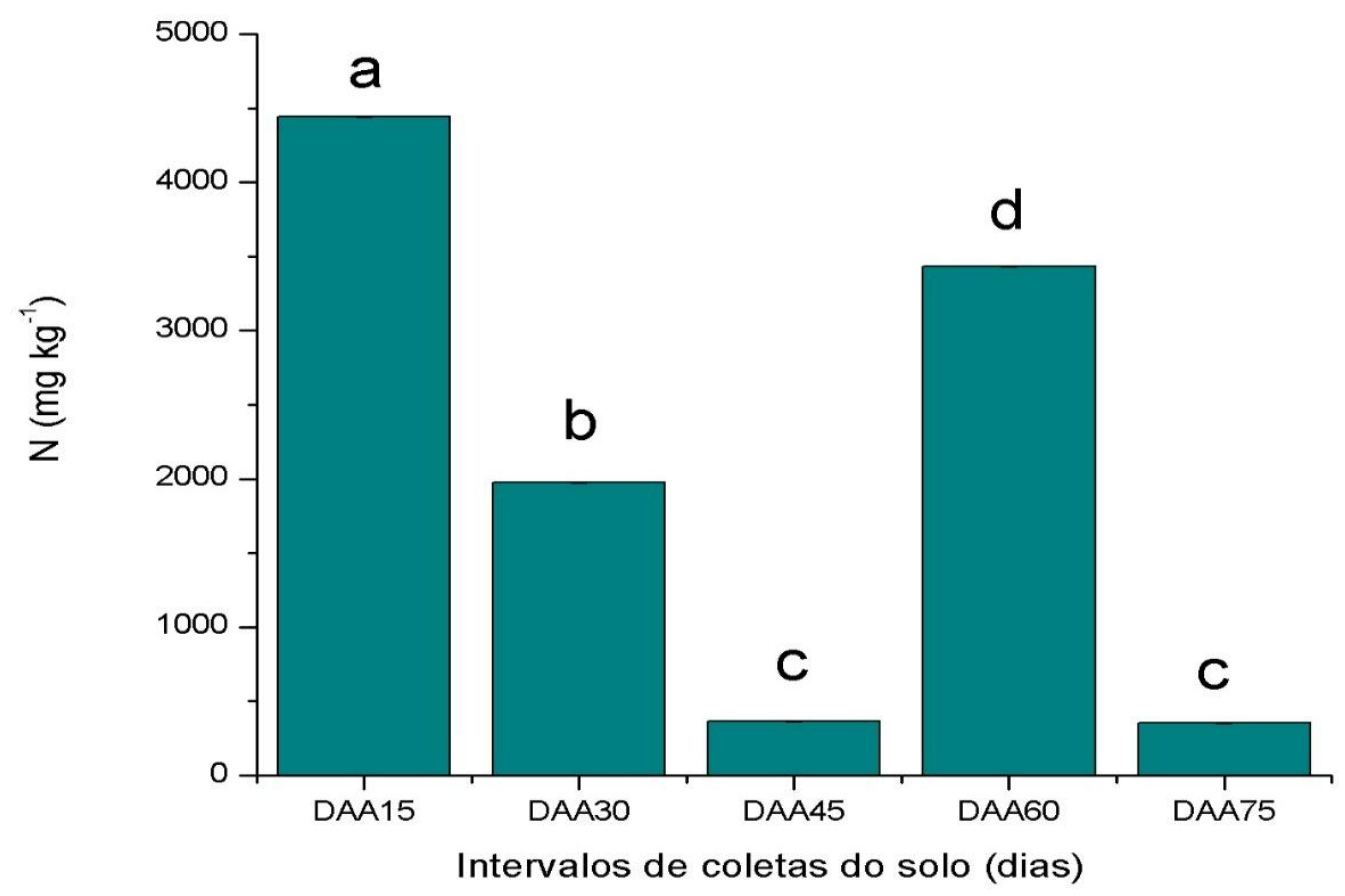


$\mathrm{Na}$ agricultura, o nitrogênio é o elemento que requer maior demanda pelos vegetais, depois do carbono, hidrogênio e oxigênio. Parte da necessidade de nitrogênio requerido pelas culturas pode ser suprida pelo solo, porém, em muitas situações o solo é incapaz de atender toda a demanda de nitrogênio, sendo necessária a fertilização nitrogenada (AGROLINK, 2016).

O nitrogênio é um dos macronutrientes primários mais utilizados, de maior absorção e mais exportados pelas culturas. É o nutriente mais lixiviado nos solos, o que requer cuidados especiais em seu manejo devido aos riscos de contaminação do lençol freático. No solo, apresenta grande dinamismo devido a sua grande variação no número de oxidação, o que possibilita uma grande variedade de combinações. Apresenta-se nas formas: $\mathrm{N}_{2}, \mathrm{NO}, \mathrm{NO}_{2}, \mathrm{~N}_{2} \mathrm{O}$, $\mathrm{NH}_{3}$ ), que favorecem as trocas constantes, principalmente como $\mathrm{NO}_{2} \mathrm{e} \mathrm{NO}_{3}{ }^{-}$extremamente móveis no solo. Sofre, também, transformações em reações mediadas por micro-organismos (AGROLINK, 2016).

Para ser utilizado biologicamente, ou seja, absorvido por plantas e outros organismos ele precisa ser fixado e combinado com outros elementos, para se tornar solúvel e consequentemente assimilável. A fixação atmosférica ocorre através dos relâmpagos, pela elevada energia que separa as moléculas de nitrogênio, permitindo que os átomos se liguem com moléculas de oxigênio existentes no ar formando monóxido de nitrogênio (NO). A fixação de nitrogênio é o processo pelo qual o nitrogênio gasoso do ar é incorporado em compostos orgânicos nitrogenados e, assim, introduzidos no ciclo do nitrogênio. A fixação industrial é de grande importância agrícola pela necessidade do uso de fertilizantes nitrogenados para suprir a demanda de nitrogênio pelas culturas (AGROLINK, 2016).

No solo, o nitrogênio está disponível através da precipitação, nas formas combinadas como a amônia e em formas orgânicas em resíduos finamente subdivididos de áreas industriais, oriundas do carreamento de $\mathrm{NH}_{3}, \mathrm{NO}_{3}{ }^{-}$e outras formas através das chuvas. A quantidade de nitrogênio que chega ao solo pelas águas da chuva, varia muito com a região e, geralmente em quantidades inferiores às demandas da maioria das espécies cultivadas (AGROLINK, 2016).

$\mathrm{O}$ nitrogênio atmosférico $\left(\mathrm{N}_{2}\right)$ não é uma forma assimilável pelas plantas, entretanto micro-organismos específicos podem fazer a redução enzimática do $\mathrm{N}_{2}$ para $\mathrm{NH}_{4}{ }^{+}$. A fixação biológica de $\mathrm{N}_{2}$ é realizada por micro-organismos, como bactérias, ciano bactérias e actinomicetos, por meio de um processo chamado de fixação biológica de nitrogênio. Alguns destes micro-organismos vivem em associação com plantas, principalmente, leguminosas, em relações simbióticas, enquanto outros micro-organismos não simbióticos fixam $\mathrm{N}_{2}$, que é liberado na forma de mineral através da decomposição da biomassa destes organismos após sua morte (AGROLINK, 2016). 
A decomposição microbiana de resíduos de plantas e animais no solo libera nitrogênio nitrito, nitrato e amônia, formas de nitrogênio que são absorvidas pela planta na solução do solo (AGROLINK, 2016).

Por ser um nutriente estrutural, constituinte das proteínas, participa de vários processos orgânicos tendo papel fundamental no metabolismo vegetal. É essencial na estrutura e funções das células, para todas as reações enzimáticas nos vegetais; está presente nas moléculas de fotossíntese, das vitaminas e carboidratos (AGROLINK, 2016).

A análise do nitrogênio total ao longo do experimento mostrou diferença estatística entre os tempos de coleta DAA15 e DAA60 e uma igualdade entre as médias dos tempos DAA45 e DAA75.

A absorção de nutrientes, em especial de nitrogênio, pela soja foi crescente ao longo do experimento, considerando-se o tempo total de 76 dias ( $3^{\text {a }}$ aplicação do bioerbicida) desde a germinação aos 31 dias e a análise do solo. A partir da $3^{\text {a }}$ coleta do solo, a absorção de nutrientes decresce devido a sua translocação para formação de novos grãos, assim como verificado por Sfredo (2008). As Figuras 41-44 mostram as plantas de soja ao longo do experimento, do surgimento das vagens, ao envelhecimento das folhas e a liberação de novas sementes.

Figura 41 - Vagem da planta de soja.

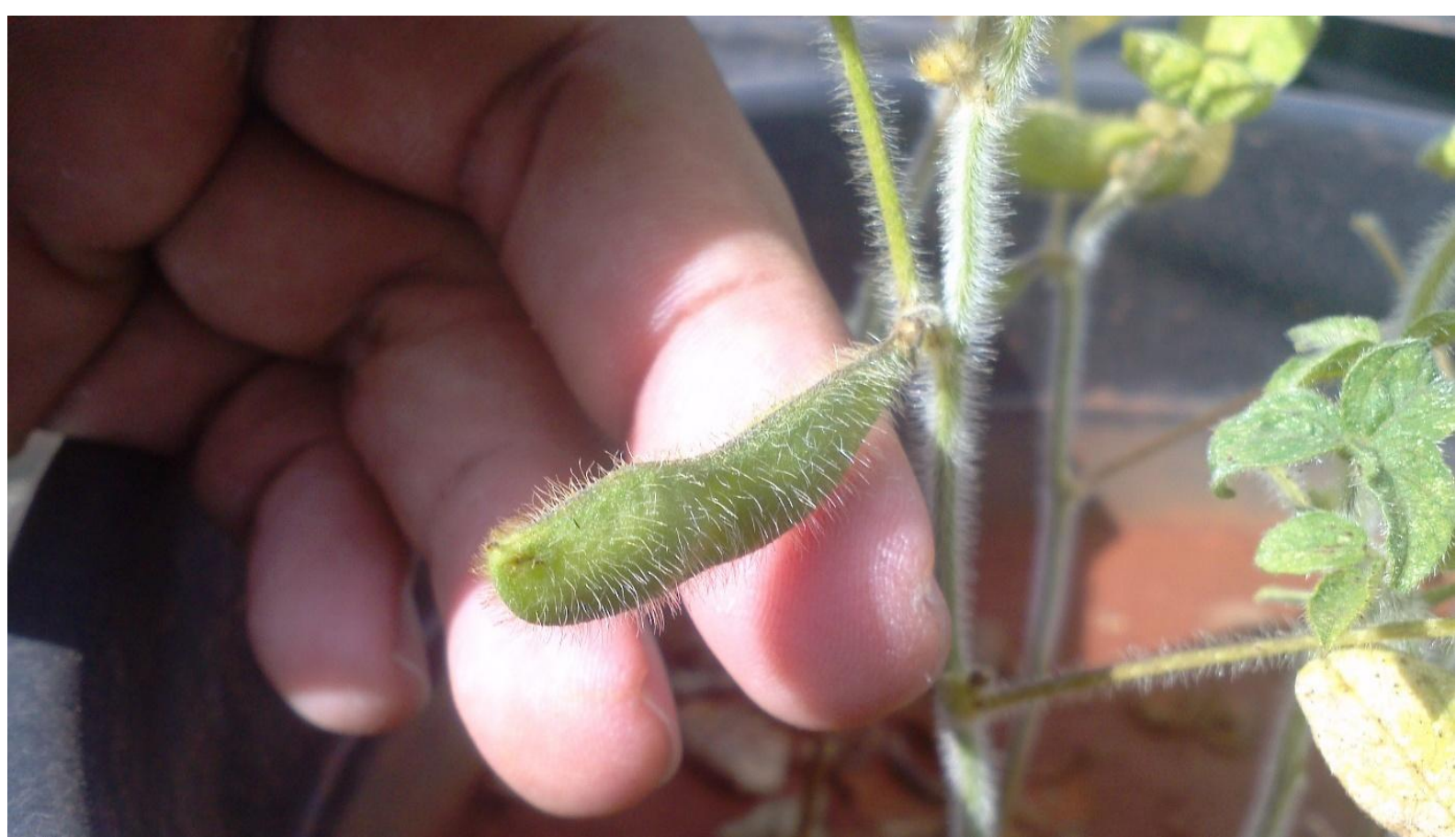

Fonte: Autoria própria. 
Figura 42 - Amarelecimento das folhas de soja.

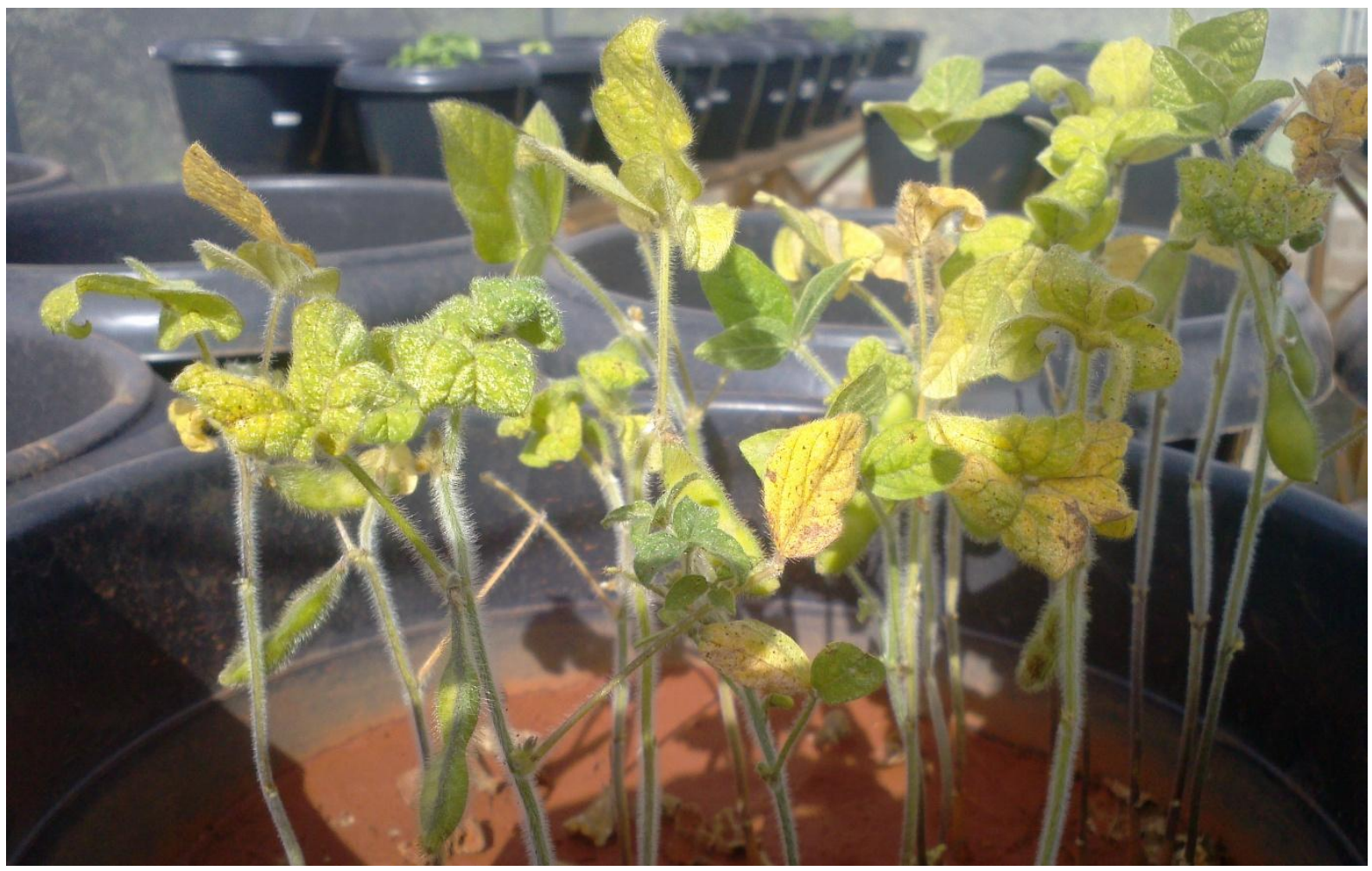

Fonte: Autoria própria.

Figura 43 - Vagem da planta de soja (estágio de pré eclosão das sementes).

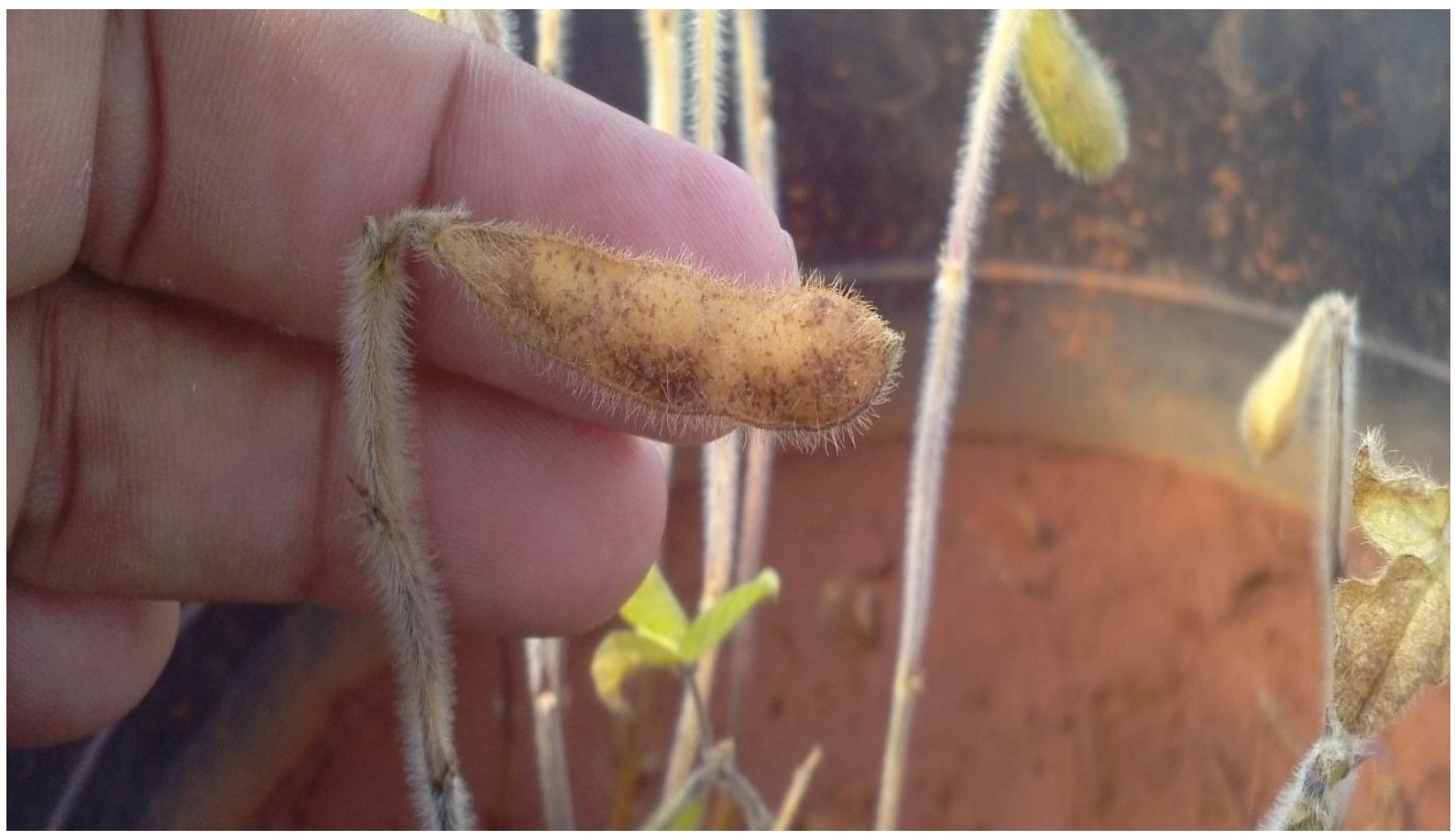

Fonte: Autoria própria. 
Figura 44 - Plantas de soja aos 76 dias do experimento (liberação das sementes).

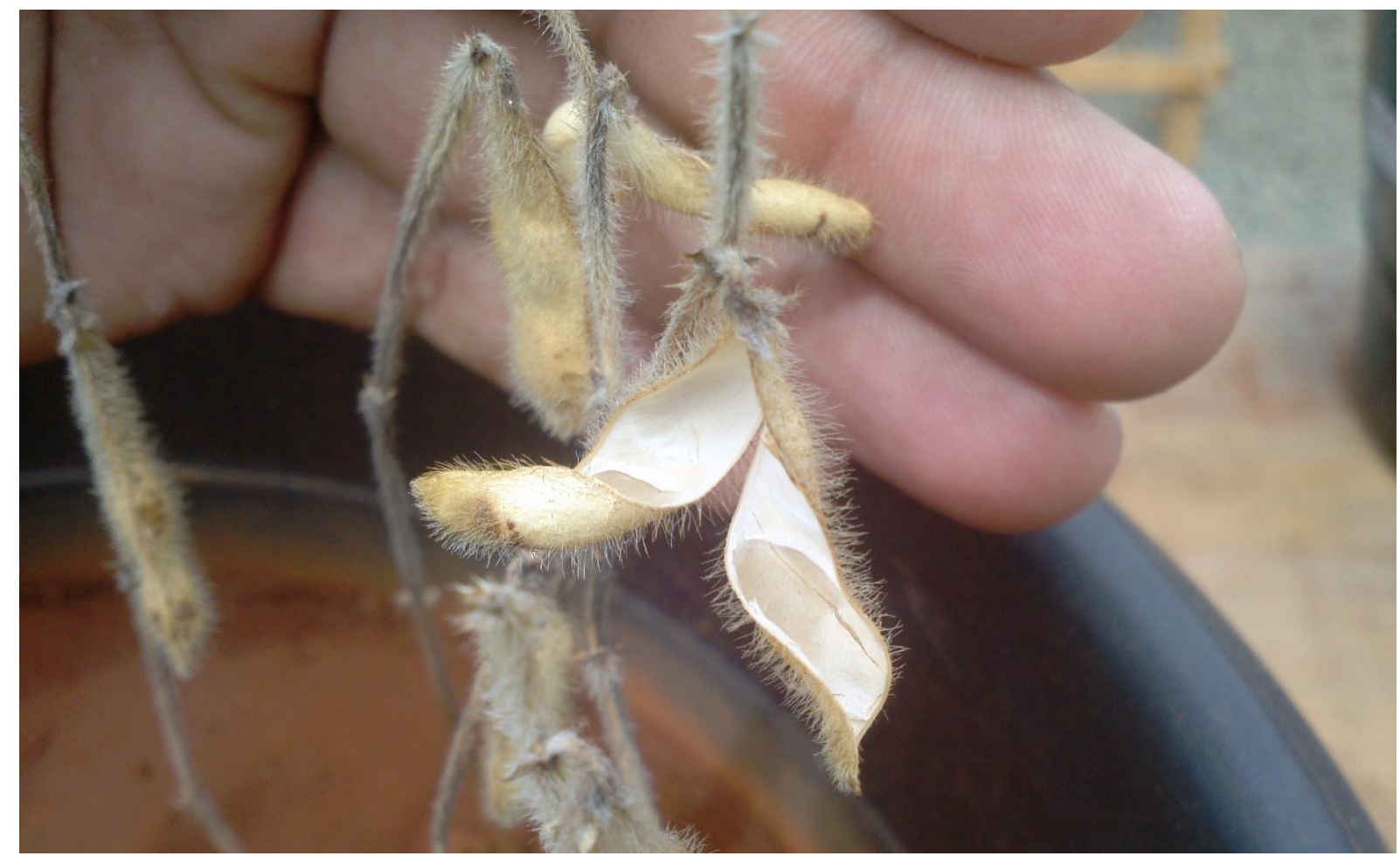

Fonte: Autoria própria.

Pela ANOVA, pôde-se observar a diminuição dos níveis de nitrogênio e consequentemente sua diferença estatística ao longo do experimento. Comparando as análises anteriores do solo e o desenvolvimento do sistema solo-planta ao tempo de coleta de DAA60, nota-se que houve um possível restabelecimento deste elemento, pois, nesta etapa as plantas já estão bem desenvolvidas e não há mais disposição excessiva deste elemento no solo e que o consumo de nutrientes é relativo ao tamanho e à quantidade de plantas invasoras no sistema, ou seja, os vasos coletados aos DAA60 do bioerbicida (4 aplicação), tinham plantas de soja em fase de crescimento e plantas invasoras em processo de inibição ou já mortas.

Assim, as análises dos níveis de nutrientes como nitrogênio e fósforo mostram a ideia de que a diminuição de nutrientes no solo está relacionada à quantidade de plantas presentes no sistema e da necessidade de absorção de nutrientes para se desenvolver. A representação do início do ciclo do nitrogênio pode ser notada entre os tempos de coleta DAA45, onde há a menor concentração de nitrogênio, passando pelo DAA60, onde há o reestabelecimento dos níveis de nitrogênio e, por fim, aos DAA75, onde há novamente a diminuição dos níveis deste nutriente no solo.

Na Tabela 28 estão os teores de nitrogênio no solo ao longo do experimento. 
Tabela 28 - Teores de nitrogênio no solo ao longo do experimento com planta Emilia sonchifolia.

\begin{tabular}{lc}
\hline Coletas (dias) & Nitrogênio $\left(\mathrm{mg} \mathrm{kg}^{-1}\right)$ \\
\hline DAA15 & $4442,33 \pm 2,51 \mathbf{a}$ \\
DAA30 & $1974,33 \pm 1,52 \mathbf{b}$ \\
DAA45 & $362,66 \pm 5,50 \mathbf{c}$ \\
DAA60 & $3434,33 \pm 5,86 \mathbf{d}$ \\
DAA75 & $355,67 \pm 5,85 \mathbf{c}$ \\
\hline
\end{tabular}

$(\mathrm{n}=3)$. Médias seguidas pela mesma letra na coluna não diferem significativamente entre si pelo teste de Tukey $(\mathrm{P}<0,05)$.

Numericamente, pode ser observado que os níveis de nitrogênio diminuíram do DAA15 até o DAA45, voltando a se restabelecer nos próximos 15 dias (DAA60) e diminuindo mais uma vez ao final do experimento aos DAA75. A diminuição dos teores de nitrogênio não está diretamente ligada ao acúmulo dos extratos no solo, já que não foi observada uma redução concentração de nitrogênio aos DAA60.

\subsubsection{Acidez trocável}

Os solos possuem uma tendência natural de se acidificarem com o passar do tempo. Vários fatores, dentre eles, material de origem, vegetação nativa, precipitação, profundidade do solo, manejo, adubação nitrogenada, decomposição da matéria orgânica, plantio direto, erosão contribuem para aumentar a acidez do solo. A acidez do solo, quando não controlada, pode reduzir seriamente o rendimento das culturas, causando perdas econômicas ao produtor e impactos negativos no ambiente. Estima-se que cerca de 30\% dos solos do planeta são ácidos e representam algumas das regiões produtoras de alimentos mais importantes (PROCHNOW, 2014).

A Figura 45 apresenta os teores da acidez trocável do solo durante as etapas de aplicação e incorporação do bioerbicida em estudo. 
Figura 45 - Acidez trocável no solo após incorporação do bioerbicida, na $1^{\mathrm{a}}, 2^{\mathrm{a}}, 3^{\mathrm{a}}, 4^{\mathrm{a}}$ e $5^{\mathrm{a}}$ aplicação. Médias seguidas pela mesma letra na coluna não diferem significativamente entre si pelo teste de Tukey $(\mathrm{P}<0,05)$.

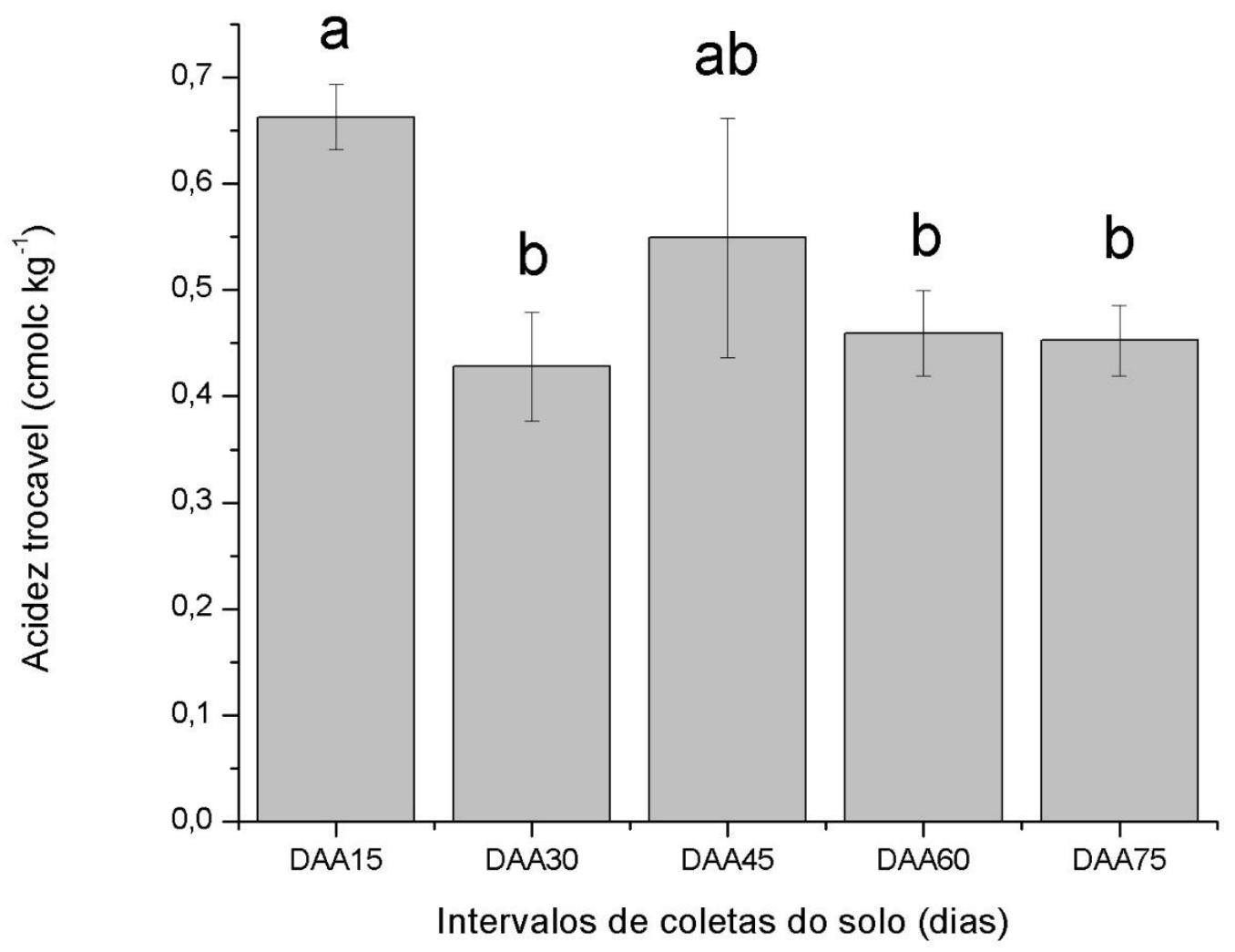

Da acidez trocável ao longo do experimento foi observado que do intervalo entre o DAA30 e o DAA75 não houve diferença estatística.

Os teores de acidez trocável ou alumínio trocável $(\mathrm{H}+\mathrm{Al})$ e matéria orgânica $(\mathrm{MO})$ são as propriedades que mais influenciam as características dos solos quanto à fertilidade. A fração orgânica do solo possui a capacidade de complexar cátions, dentre eles o Al. Assim, no sistema plantio direto, devido aos maiores teores de matéria orgânica em relação ao sistema convencional de cultivo, com preparo do solo, a quantidade de Al complexado (Al-MO) tornase de grande importância devido a sua predominância na forma trocável $\left(\mathrm{Al}^{+3}\right)(\mathrm{ZAMBROSI}$, ALLEONI; CAIRES, 2007).

A acidez trocável do solo diminuiu após a aplicação do bioerbicida nas plantas invasoras e posterior incorporação no solo, onde, do DAA30 até o DAA75 todas as determinações foram estatisticamente iguais. A Figura 44 mostra que após a primeira etapa de coleta e análise (DAA15) do solo, os níveis de acidez mantiveram-se em igualdade estatística até o fim do 
experimento, com níveis mais baixos em relação ao início do experimento. A diferença na acidez do solo começa a ser notória com as sucessivas aplicações, apesar de não verificarmos o aumento gradual da acidez com a adição dos extratos no sistema. A acidez do solo pode ser avaliada do ponto de vista do modo de aplicação e da condição inicial do experimento, ou seja, do porte (tamanho) das plantas presentes no sistema e portanto da área das folhas a serem atingidas por meio de pulverização do bioerbicida e sua dispersão. As aplicações do bioerbicida eram feitas por meio de pulverização, em um sistema constituído de plantas invasoras da Emilia sonchifolia e plantas de soja. No início das aplicações, as plantas invasoras estavam em estágio inicial de desenvolvimento com folhas de aproximadamente $3 \mathrm{~cm}$ de comprimento. Em resumo, pode-se dizer que na etapa inicial de aplicação, onde o porte das plantas invasoras era pequeno, o modo de aplicação dos extratos ocasionava o contato direto do bioerbicida no solo, diferentemente das demais etapas em que as plantas no sistema estavam em desenvolvimento e a área foliar em constante crescimento, diminuindo assim, o aporte bioerbicida no solo. A Tabela 29 apresenta os teores de acidez trocável no solo ao longo do experimento.

Tabela 29 - Teores de acidez trocável do solo ao longo do experimento com planta Emilia sonchifolia.

\begin{tabular}{ll}
\hline Coletas (dias) & Acidez trocável $\left(\mathrm{cmol}_{\mathrm{c}} \mathrm{kg}^{-1}\right)$ \\
\hline DAA15 & $0,66 \pm 0,03 \mathbf{a}$ \\
DAA30 & $0,43 \pm 0,05 \mathbf{b}$ \\
DAA45 & $0,55 \pm 0,11 \mathbf{a b}$ \\
DAA60 & $0,46 \pm 0,04 \mathbf{b}$ \\
DAA75 & $0,45 \pm 0,03 \mathbf{b}$
\end{tabular}

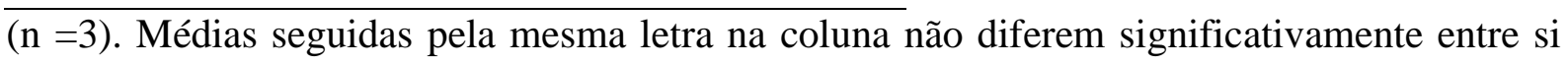
pelo teste de Tukey $(\mathrm{P}<0,05)$.

Pelos dados da Tabela 29, nota-se que os teores de acidez do solo não aumentaram proporcionalmente às aplicações dos extratos, em geral, os teores de acidez do solo aos DAA60 e DAA75 foram significativamente iguais, mesmo após a $5^{\mathrm{a}}$ e $6^{\mathrm{a}}$ aplicação dos extratos nas plantas, respectivamente. Considerando-se que o teor de acidez trocável no tempo zero $(0,11$ $\mathrm{cmol}_{\mathrm{C}} \mathrm{kg}^{-1}$ ) foi menor em relação à análise do solo aos DAA15, é possível afirmar que o contato dos extratos no solo causou essa alteração na acidez do solo. 


\subsubsection{Capacidade de troca catiônica (CTC)}

A CTC no solo está ligada à capacidade de retenção e disponibilidade de cátions/nutrientes às plantas. Na Figura 46 é mostrado o comportamento do solo durante as etapas do experimento, no tocante à CTC.

Figura 46 - Capacidade de troca catiônica no solo após incorporação do bioerbicida, na $1^{\mathrm{a}}, 2^{\mathrm{a}}$, $3^{\mathrm{a}}, 4^{\mathrm{a}}$ e $5^{\mathrm{a}}$ aplicação. Médias seguidas pela mesma letra na coluna não diferem significativamente entre si pelo teste de Tukey $(\mathrm{P}<0,05)$.

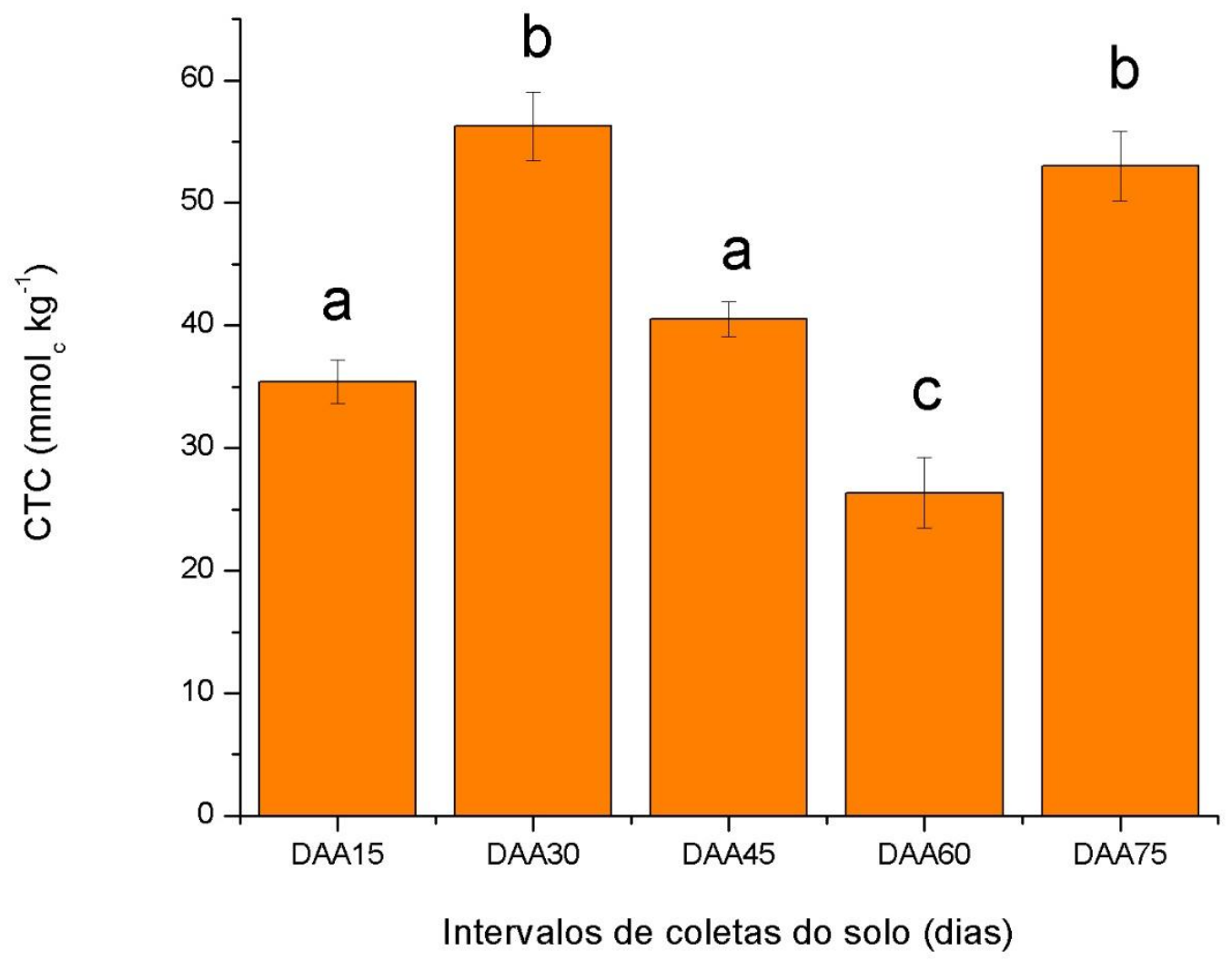

O tempo de coleta aos 15 dias apresenta um valor mais baixo em relação ao solo no tempo zero $\left(73,63 \mathrm{mmol}_{\mathrm{c}} \mathrm{kg}^{-1}\right)$, provavelmente devido ao fato de que nesta etapa as plantas estão se desenvolvendo, ou seja, nesta etapa são disponibilizados os nutrientes necessários para o desenvolvimento das plantas. Em consequência disto, nutrientes estão sendo consumidos de forma diferente para cada grupo plantas no experimento, considerando-se a quantidade de plantas invasoras que conseguiram germinar e a competição por nutrientes em relação à média de plantas de soja em cada vaso. 
A coleta ao DAA60 mostra um nível mais baixo da CTC do solo e estatisticamente diferente das demais análises do solo. Nesta etapa a soja já está bem estabelecida no solo e as plantas invasoras remanescentes às aplicações anteriores estão em processo de inibição do crescimento ou mortas, assim, podemos considerar o fato de uma $4^{\mathrm{a}}$ aplicação dos extratos e o possível acúmulo deste ao longo do experimento indicar um possível efeito deletério quanto a fertilidade do solo. Na Tabela 30 estão os teores da capacidade de troca catiônica (CTC) no solo ao longo do experimento.

Tabela 30 - Teores de capacidade de troca catiônica (CTC) do solo ao longo do experimento com planta Emilia sonchifolia.

\begin{tabular}{ll}
\hline Coletas (dias) & CTC $\left(\mathrm{mmol}_{\mathrm{c}} \mathrm{kg}^{-1}\right)$ \\
\hline DAA15 & $32,09 \pm 6,70 \mathbf{a}$ \\
DAA30 & $59,59 \pm 4,97 \mathbf{b}$ \\
DAA45 & $37,18 \pm 6,59 \mathbf{a}$ \\
DAA60 & $29,69 \pm 4,94 \mathbf{c}$ \\
DAA75 & $46,37 \pm 7,59 \mathbf{b}$ \\
\hline
\end{tabular}

$(\mathrm{n}=3)$. Médias seguidas pela mesma letra na coluna não diferem significativamente entre si pelo teste de Tukey $(\mathrm{P}<0,05)$.

Os dados de CTC mostram um solo com baixa capacidade de troca de cátions, entretanto, associando as variações nos níveis de CTC com os níveis de nutrientes e o próprio experimento, pode dizer que a adição dos extratos causaram alguma alteração nas características do solo, já que entre os intervalos de coleta DAA15 e DAA30 houve um aumento dos níveis de CTC, mesmo em função de uma segunda dose dos extratos contendo o bioerbicida e que não houve uma diminuição da CTC proporcional às aplicações cumulativas dos extratos. $\mathrm{Na}$ análise aos DAA75 é possível notar o restabelecimento dos níveis da CTC do solo e a semelhança estatística com os valores obtidos aos DAA30, logo, apesar de não ser observada uma tendência na diminuição da CTC com as aplicações adicionais do bioerbicida, há uma perturbação e, consequentemente, um prejuízo na fertilidade do solo quando comparamos os teores da CTC do DAA15 ao DAA75 com o valor obtido no tempo zero. 


\subsubsection{Carbono orgânico total}

A Figuras 47 apresenta os resultados dos teores de carbono orgânico do solo durante as etapas de aplicação e incorporação do bioerbicida em estudo.

Figura 47 - Teor de carbono orgânico no solo após incorporação do bioerbicida, na $1^{\mathrm{a}}, 2^{\mathrm{a}}, 3^{\mathrm{a}}$, $4^{\mathrm{a}}$ e $5^{\mathrm{a}}$ aplicação. Médias seguidas pela mesma letra na coluna não diferem significativamente entre si pelo teste de Tukey $(\mathrm{P}<0,05)$.

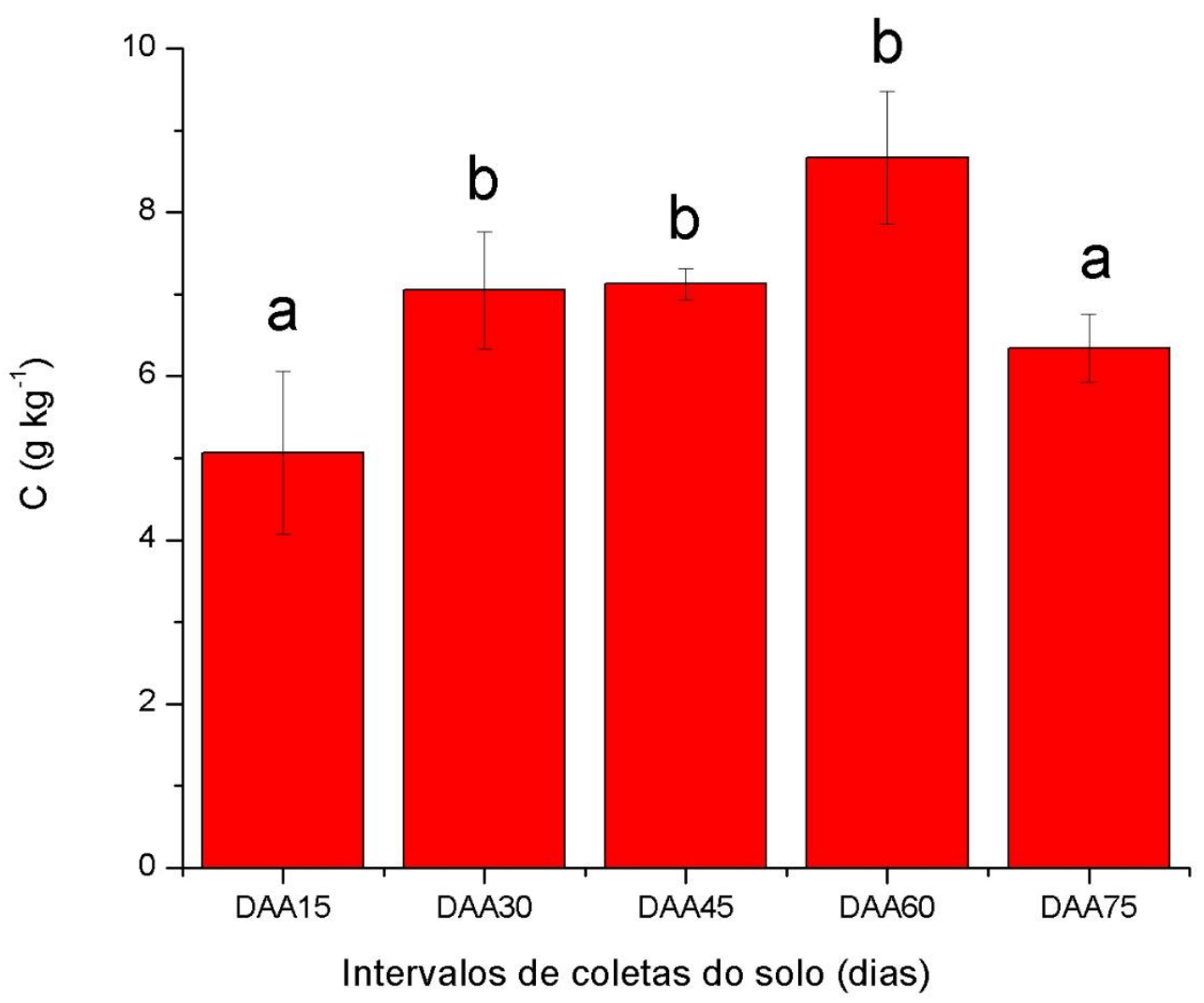


O ligeiro aumento nos níveis de carbono podem ser relacionados à matéria seca proveniente da queda das folhas no solo, já em processo de decomposição. A matéria orgânica presente no solo aumenta o poder tamponante do solo e diminui os perigos de desequilíbrios minerais. A coleta do solo aos DAA60 mostra a etapa do processo em que a maior parte das plantas invasoras combatidas pelo bioerbicida já estão mortas e a soja já está bem desenvolvida, terminando um ciclo da cultura e produzindo novas sementes. A queda das folhas da própria soja, restos de pequenos insetos e o acúmulo de material (pequenos galhos e folhas) da espécie invasora propiciam o aumento dos níveis de carbono nesta etapa, por meio da decomposição. Na Tabela 31 estão os teores de carbono orgânico total no solo ao longo do experimento.

Tabela 31 - Teores de carbono orgânico total no solo ao longo do experimento com planta Emilia sonchifolia.

\begin{tabular}{ll}
\hline Coletas (dias) & $\begin{array}{l}\text { Carbono orgânico } \\
\left(\mathrm{g} \mathrm{kg}^{-1}\right)\end{array}$ \\
\hline DAA15 & $5,06 \pm 0,99 \mathbf{a}$ \\
DAA30 & $7,04 \pm 0,72 \mathbf{b}$ \\
DAA45 & $7,12 \pm 0,19 \mathbf{b}$ \\
DAA60 & $8,67 \pm 0,80 \mathbf{b}$ \\
DAA75 & $6,34 \pm 0,41 \mathbf{a}$
\end{tabular}

$(\mathrm{n}=3)$. Médias seguidas pela mesma letra na coluna não diferem significativamente entre si pelo teste de Tukey $(\mathrm{P}<0,05)$.

Os teores de carbono não apresentaram uma tendência a diminuir com as aplicações cumulativas dos extratos, entretanto, a igualdade estatística observada principalmente do DAA30 até o DAA60, podem estar relacionadas ao acúmulo de folhas mortas afetadas pela ação do bioerbicida.

\subsection{Analise de variância dos dados (ANOVA)}

ANOVA é um tipo de método paramétrico para comparação de médias e é uma extensão do teste-t. Quando há mais que dois grupos para ser comparado o teste-t pareado não é apropriado e a ANOVA deve ser usada. A ANOVA requer a normalidade dos dados e um teste de igualdade de variância. A ANOVA é aplicada quando se quer averiguar a diferença estatística de um conjunto de dados. A principal aplicação da ANOVA é na comparação de médias oriundas de grupos diferentes, chamado também de tratamentos, como exemplo, 
aplicações de diferentes dosagens de analgésico em pacientes, entre outros (ORIGIN, 2007; VIEIRA, 2006).

Para se realizar o teste de ANOVA, é necessário que se tenham duas hipóteses: uma nula e uma alternativa. Como resposta, o valor de $\mathrm{P}$ é o indicativo. Se o valor de $\mathrm{P}$ for menor que 0,05 (95\% de confiança), a hipótese nula é confirmada, ou seja, todos os dados são estatisticamente diferentes entre si. Se o valor de $\mathrm{P}$ for superior a 0,05 , as médias dos dados são estatisticamente iguais entre si (MILONE, 2009).

Para a análise de variância é necessário haver uma variável de resposta contínua e pelo menos um fator categórico com dois ou mais níveis. As análises de variância exigem dados de populações normalmente distribuídas com variâncias iguais entre fatores. Entretanto, os procedimentos de análise de variância funcionam bem mesmo quando a pressuposição de normalidade é violada (MINITAB, 2015).

O nome 'análise de variância' é baseado na abordagem na qual o procedimento usa variâncias para determinar se as médias são diferentes. O procedimento compara a variância entre as médias do grupo à variância dentro dos grupos como para determinar se os grupos são todos parte de uma população maior ou população separadas com características diferentes (MINITAB, 2015).

O teste de normalidade é usado para determinar se os dados obtidos de uma amostra seguem uma distribuição normal. Uma das análises estatísticas para testar a normalidade é o método de Shapiro-Wilk (ORIGIN, 2007). A Tabela 32 mostra o teste de normalidade dos dados antes dos cálculos de variância estatística dos elementos no solo. 
Tabela 32- Distribuição normal dos dados obtidos da caracterização do solo referente ao uso do bioerbicida na planta invasora Emilia sonchifolia.

\begin{tabular}{lccc}
\hline & Graus de liberdade & $\begin{array}{c}\text { Estatística: Shapiro- } \\
\text { Wilk (W) }\end{array}$ & P-valor* \\
\hline $\mathrm{pH}($ água $)$ & 15 & 0,98066 & 0,97383 \\
$\mathrm{pH}\left(\mathrm{CaCl}_{2}\right)$ & 15 & 0,77127 & 0,00161 \\
$\mathrm{H}+\mathrm{Al}$ & 15 & 0,88275 & 0,05216 \\
Potássio & 15 & 0,96392 & 0,76015 \\
Fósforo & 15 & 0,83012 & 0,00927 \\
Cálcio & 15 & 0,83138 & 0,00957 \\
Nitrogênio & 15 & 0,86244 & 0,02617 \\
CTC & 15 & 0,93744 & 0,35127 \\
Carbono orgânico & 15 & 0,97473 & 0,92086 \\
$*(\mathrm{P}<0,05)$ & & &
\end{tabular}

$*(\mathrm{P}<0,05)$.

Pela regra de decisão do teste de Shapiro-Wilk, tendo como exemplo os dados do teor de potássio, temos $\mathrm{W}_{\text {calculado }}=0,96392>0,881_{(0,05,15)}$, com o valor de $\mathrm{P}$ calculado $=0,76015>$ 0,05. Assim, podemos afirmar com o nível de 5\% que a amostra provêm de uma população normal. O teste de normalidade Shapiro-Wilk foi realizado por meio do software Origin pro 8.

A ANOVA não pressupõe que toda a coluna de resposta siga uma distribuição normal. A ANOVA pressupõe que os resíduos do modelo sigam uma distribuição normal. Logo, mesmo quando a pressuposição de normalidade é violada, o procedimento ANOVA pode ser utilizado.

Na Tabela 33 estão dispostos os resultados da caracterização do solo após aplicação e incorporação do bioerbicida, por meio da análise de variância (ANOVA). Ao final do experimento, a caracterização do solo referência foi realizada e comparada estatisticamente com a amostra de solo da última coleta (75 dias). A Tabela 34 mostra a ANOVA dos dados da última coleta e do solo referência. 
Tabela 33 - Resultados da análise do solo após aplicação e incorporação do bioerbicida, durante os experimentos com a planta Emilia sonchifolia.

\begin{tabular}{|c|c|c|c|c|c|c|c|c|c|}
\hline $\begin{array}{c}\text { Tempo } \\
\text { de } \\
\text { coleta }\end{array}$ & $\begin{array}{c}\mathrm{pH} \\
\left(\mathrm{H}_{2} \mathrm{O}\right)\end{array}$ & $\begin{array}{c}\mathrm{pH} \\
\left(\mathrm{CaCl}_{2}\right)\end{array}$ & $\mathrm{H}+\mathrm{Al}$ & K & $\mathrm{P}_{\text {disp }}$ & $\mathrm{Ca}$ & $\mathrm{N}$ Total & CTC Total & $\mathrm{CO}$ \\
\hline Dias* & & & $\mathrm{cmol}_{\mathrm{c}} \mathrm{kg}^{-1}$ & -----mg & $\mathrm{n}^{-3}-----$ & $\mathrm{cmol} \mathrm{dm}^{-3}$ & $\mathrm{mg} \mathrm{kg}^{-1}$ & $\mathrm{mmol}_{\mathrm{c}} \mathrm{kg}^{-1}$ & $\mathrm{~g} \mathrm{~kg}^{-1}$ \\
\hline DAA15 & $5,65 \mathbf{a}$ & $4,67 \mathbf{a}$ & $0,66 \mathbf{a}$ & $2,90 \mathbf{a}$ & $0,11 \mathbf{a}$ & $17,11 \mathbf{a}$ & $4442,3 \mathbf{a}$ & $32,09 \mathbf{a}$ & $5,06 \mathbf{a}$ \\
\hline DAA30 & $5,53 \mathbf{a}$ & $4,66 \mathbf{a}$ & $0,43 \mathbf{b}$ & $2,83 \mathbf{a}$ & $0,14 \mathbf{a}$ & $16,94 \mathbf{a}$ & $1974,3 \mathbf{b}$ & $56,26 \mathbf{b}$ & $7,04 \mathbf{b}$ \\
\hline DAA45 & $5,58 \mathbf{a}$ & $4,66 \mathbf{a}$ & $0,55 \mathbf{a b}$ & $2,73 \mathbf{a}$ & $0,06 \mathbf{a}$ & $16,83 \mathbf{a}$ & $362,6 \mathbf{c}$ & $40,51 \mathbf{a}$ & $7,12 \mathbf{b}$ \\
\hline DAA60 & $5,63 \mathbf{a}$ & $4,83 \mathbf{a}$ & $0,46 \mathbf{b c}$ & $3,03 \mathbf{a b}$ & $0,02 \mathbf{a}$ & $21,54 \mathbf{a}$ & $3434,3 \mathbf{d}$ & $26,36 \mathbf{a}$ & $8,67 \mathbf{b}$ \\
\hline DAA75 & $5,80 \mathbf{a}$ & $4,76 \mathbf{a}$ & $0,45 \mathbf{b c}$ & $2,36 \mathbf{a c}$ & $0,38 \mathbf{b}$ & $13,27 \mathbf{a}$ & $355,6 \mathbf{c}$ & $53,03 \mathbf{b}$ & $6,34 \mathbf{a}$ \\
\hline
\end{tabular}

H+Al (acidez trocável), CTC (capacidade de troca catiônica), MO (matéria orgânica), CO (carbono orgânico). *intervalo de coleta e análise do solo após aplicação do bioerbicida. Médias seguidas pela mesma letra na coluna não diferem significativamente entre si pelo teste de Tukey $(P<0,05)$.

Tabela 34 - Resultados da análise do solo referência (R) e do solo analisado aos DAA75, durante os experimentos com a planta Emília sonchifolia.

\begin{tabular}{lccccccccc}
$\begin{array}{c}\text { Tempo } \\
\text { de } \\
\text { coleta }\end{array}$ & $\begin{array}{c}\mathrm{pH} \\
\left(\mathrm{H}_{2} \mathrm{O}\right)\end{array}$ & $\begin{array}{c}\mathrm{pH} \\
\left(\mathrm{CaCl}_{2}\right)\end{array}$ & $\mathrm{H}+\mathrm{Al}$ & $\mathrm{K}$ & $\mathrm{P}_{\text {disp }}$ & $\mathrm{Ca}$ & $\mathrm{N}$ Total & $\mathrm{CTC}$ Total & $\mathrm{CO}$ \\
\hline Dias* & & & $\mathrm{cmol}_{\mathrm{c}} \mathrm{kg}^{-1}$ & $----\mathrm{mg} \mathrm{dm}{ }^{-3}----$ & $\mathrm{cmol} \mathrm{dm}^{-3}$ & $\mathrm{mg} \mathrm{kg}^{-1}$ & $\mathrm{mmol}_{\mathrm{c}} \mathrm{kg}^{-1}$ & $\mathrm{~g} \mathrm{~kg}^{-1}$ \\
DAA75 & $5,80 \mathbf{a}$ & $4,76 \mathbf{a}$ & $0,45 \mathbf{a}$ & $2,36 \mathbf{a}$ & $0,38 \mathbf{a}$ & $13,27 \mathbf{a}$ & $355 \mathbf{a}$ & $53,03 \mathbf{a}$ & $6,34 \mathbf{a}$ \\
$\mathrm{R}$ & $5,91 \mathbf{a}$ & $4,71 \mathbf{a}$ & $0,45 \mathbf{a}$ & $2,70 \mathbf{a}$ & $0,40 \mathbf{a}$ & $11,06 \mathbf{a}$ & $627 \mathbf{b}$ & $72,81 \mathbf{b}$ & $5,38 \mathbf{a}$ \\
\hline
\end{tabular}

H+Al (acidez trocável), CTC (capacidade de troca catiônica), MO (matéria orgânica), CO (carbono orgânico). *Intervalo de coleta e análise do solo após aplicação do bioerbicida. Médias seguidas pela mesma letra na coluna não diferem significativamente entre si pelo teste de Tukey $(P<0,05)$. 
O solo referência foi utilizado para comparar as alterações químicas causadas ao longo do experimento com as aplicações sequenciais do bioerbicida. Logo, de acordo a Tabela 33, os níveis de nutrientes na amostra de solo coletada aos DAA75, correspondente a $5^{\text {a }}$ aplicação cumulativa do bioerbicida, foi estatisticamente igual ao solo sem aplicação dos extratos, com exceção dos níveis de nitrogênio e CTC. O teor de nitrogênio no solo referência pode estar relacionados ao bom desenvolvimento das culturas no solo, em outras palavras, ambas as plantas no vaso (soja e invasora) estavam bem desenvolvidas, o que justifica uma concentração maior de nitrogênio no solo. No solo aos DAA75, as plantas invasoras do sistema já tinham sido controladas, assim, a concentração baixa pode estar relacionada ao consumo de nitrogênio pela soja que nesta etapa do experimento começava um novo ciclo. Já os valores de CTC aos DAA75 indicam que o contato dos extratos no solo causou prejuízo quanto à fertilidade, apresentando níveis menores em relação aos determinados no solo referência analisados no mesmo tempo, ou seja, aos DAA75.

\subsection{Caracterização química das amostras de solo sob o cultivo da Sida spinosa}

Nesta etapa do experimento foram avaliadas as possíveis alterações no solo em relação as sucessivas aplicações do bioerbicida obtido das folhas da planta Canavalia ensiformis no combate à planta invasora Sida Spinosa (guanxuma) no cultivo de soja convencional.

\subsubsection{Ensaios em casa de vegetação}

Sobre condições de casa de vegetação, todas as plantas invasoras nos vasos foram tratadas com o bioerbicida na concentração de $200 \mathrm{~g} \mathrm{~L}^{-1}$ utilizando-se um volume de aplicação de $3 \mathrm{~mL}$ por planta, mostrando sintomas de fitotoxicidade (apoptose) em torno de 16 dias.

Sabendo-se que o bioerbicida causa injúria na cultura de soja e têm ação inibitória no desenvolvimento da planta invasora Emilia sonchifolia, uma nova metodologia foi avaliada. Nesta etapa, foram utilizados um total de 16 vasos, cada vaso constituído de soja + planta invasora (Sida spinosa), distribuídos em quatro triplicatas + um vaso controle (referência), associados a cada etapa de avaliação/coleta do solo (15, 30, 45 e 60 dias). Neste experimento o bioerbicida utilizado foi extraído em condições otimizadas e preparado na concentração de 200 $\mathrm{g} \mathrm{L}^{-1}$ para aplicação. Na Tabela 35 são apresentados os dados comparativos das características do solo, após a coleta e após 15 dias do início dos experimentos. 
Tabela 35 - Caracterização química inicial do solo e 15 dias após o início dos experimentos em casa de vegetação com a planta Sida spinosa.

\begin{tabular}{cccccccccc}
\hline & $\mathrm{pH}$ & $\mathrm{pH}$ & $\mathrm{H}+\mathrm{Al}$ & $\mathrm{K}$ & $\mathrm{P}_{\text {disp }}$ & $\mathrm{Ca}$ & $\mathrm{N}$ Total & $\mathrm{CTC}$ & $\mathrm{CO}$ \\
& $\left(\mathrm{H}_{2} \mathrm{O}\right)$ & $\left(\mathrm{CaCl}_{2}\right)$ & & & & & & Total & \\
\hline & & & $\mathrm{cmol}_{\mathrm{c}} \mathrm{kg}^{-1}$ & $-----\mathrm{mg} \mathrm{dm}^{-3}-----$ & $\mathrm{cmol} \mathrm{dm}^{-3}$ & $\mathrm{mg} \mathrm{kg}^{-1}$ & $\mathrm{mmol}_{\mathrm{c}} \mathrm{kg}^{-1}$ & $\mathrm{~g} \mathrm{~kg}^{-1}$ \\
$\mathrm{Solo}^{1}$ & $5,82 \mathbf{a}$ & $5,22 \mathbf{a}$ & $0,12 \mathbf{a}$ & $2,13 \mathbf{a}$ & $0,22 \mathbf{a}$ & $25,17 \mathbf{a}$ & $1951,6 \mathbf{a}$ & $85,76 \mathbf{a}$ & $5,48 \mathbf{a}$ \\
$\mathrm{Solo}^{2}$ & $5,86 \mathbf{b}$ & $5,20 \mathbf{a}$ & $0,09 \mathbf{b}$ & $2,90 \mathbf{b}$ & $0,24 \mathbf{a}$ & $17,32 \mathbf{b}$ & $825,6 \mathbf{b}$ & $31,06 \mathbf{b}$ & $6,16 \mathbf{a}$
\end{tabular}

${ }^{1}$ Solo analisado após a coleta. ${ }^{2}$ Solo analisado após 15 dias do início dos experimentos. Médias seguidas pela mesma letra na coluna não diferem significativamente entre si pelo teste de Tukey $(\mathrm{P}<0,05)$ 
Assim como no experimento anterior, algumas alterações nas características do solo com a implantação das culturas e o contato dos extratos foram observadas, neste caso, estatisticamente, os níveis de nitrogênio e CTC podem ser citados. De modo geral a diferença estatística dos dados remete ao consumo de nitrogênio e outros nutrientes e a disponibilidade destes (CTC) no desenvolvimento e implantação de uma cultura no solo. Quanto à CTC pode ser dito que a ação dos extratos nas plantas invasoras e, consequentemente, o contato deste no solo alteraram a fertilidade do solo. A Figura 48 mostra as médias das temperaturas e precipitação durante o experimento com a planta invasora Sida spinosa.

Figura 48 - Média das temperaturas e precipitação durante o experimento com a planta invasora Sida spinosa. Média t máxima (média das temperaturas máximas). Média t mínima (média das temperaturas mínimas).

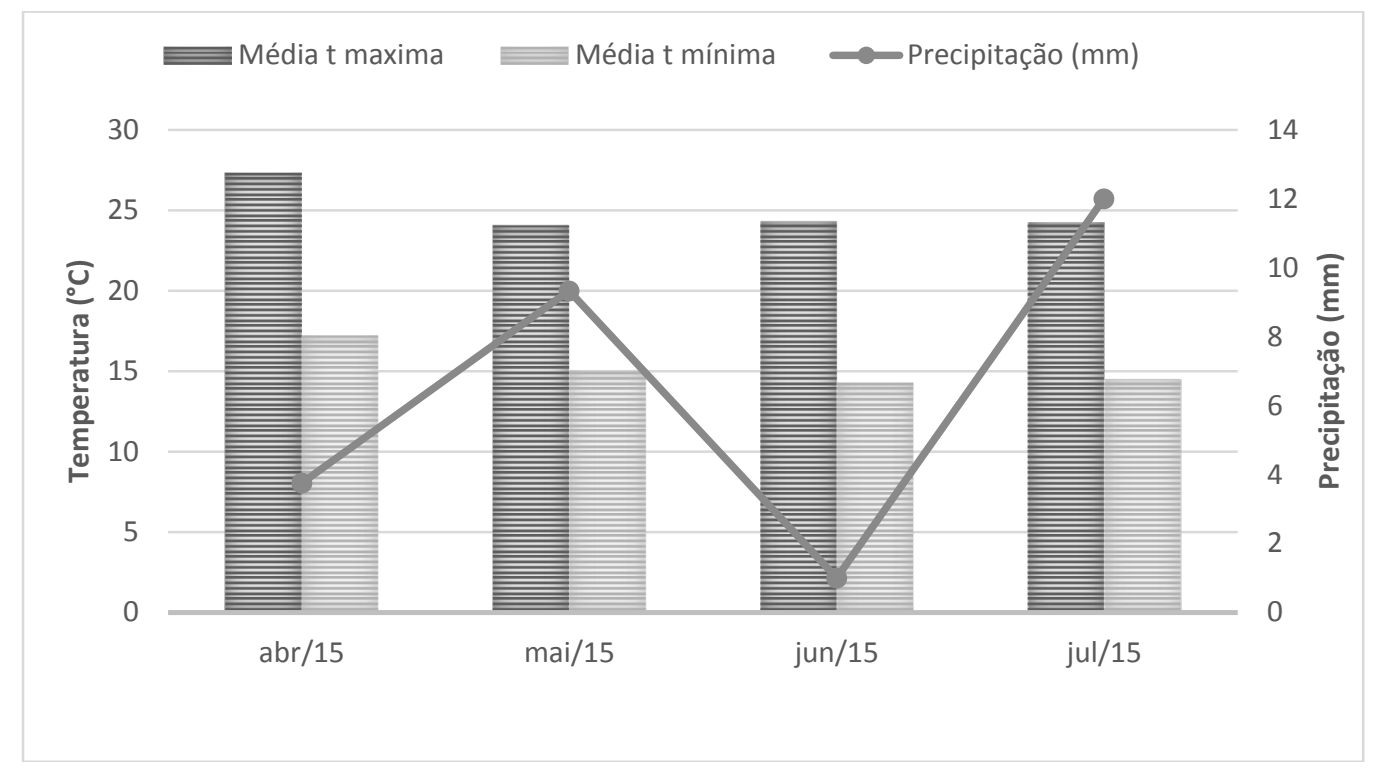

Pela Figura 48, nota-se que o experimento foi conduzido em um período de temperaturas amenas, com temperaturas máximas em torno de $25^{\circ}$ e mínimas em torno de $15^{\circ} \mathrm{C}$, com uma média de chuvas superior no mês de Junho, em relação aos demais meses.

Para a interpretação dos resultados foi feita uma análise de variância (ANOVA) dos dados para cada elemento dentro dos intervalos de coleta afim de se avaliar qualquer alteração nas características do solo com a aplicação do bioerbicida. 


\subsection{Análise do solo após aplicação do bioerbicida}

\subsection{1 pH}

A Figura 49 apresenta a análise do $\mathrm{pH}$ do solo durante as etapas de aplicação e incorporação do bioerbicida em estudo em comparação ao solo referência. Foram realizadas também medidas do $\mathrm{pH}$ do solo em água, pela similaridade dos valores, serão mostrados apenas os valores de $\mathrm{pH}$ em solução de $\mathrm{CaCl}_{2}$.

Figura 49 - pH $\left(\mathrm{CaCl}_{2}\right)$ no solo após incorporação do bioerbicida, na $1^{\mathrm{a}}, 2^{\mathrm{a}}, 3^{\mathrm{a}}$ e $4^{\mathrm{a}}$ aplicação. Médias seguidas pela mesma letra na coluna não diferem significativamente entre si pelo teste de Tukey $(P<0,05)$.

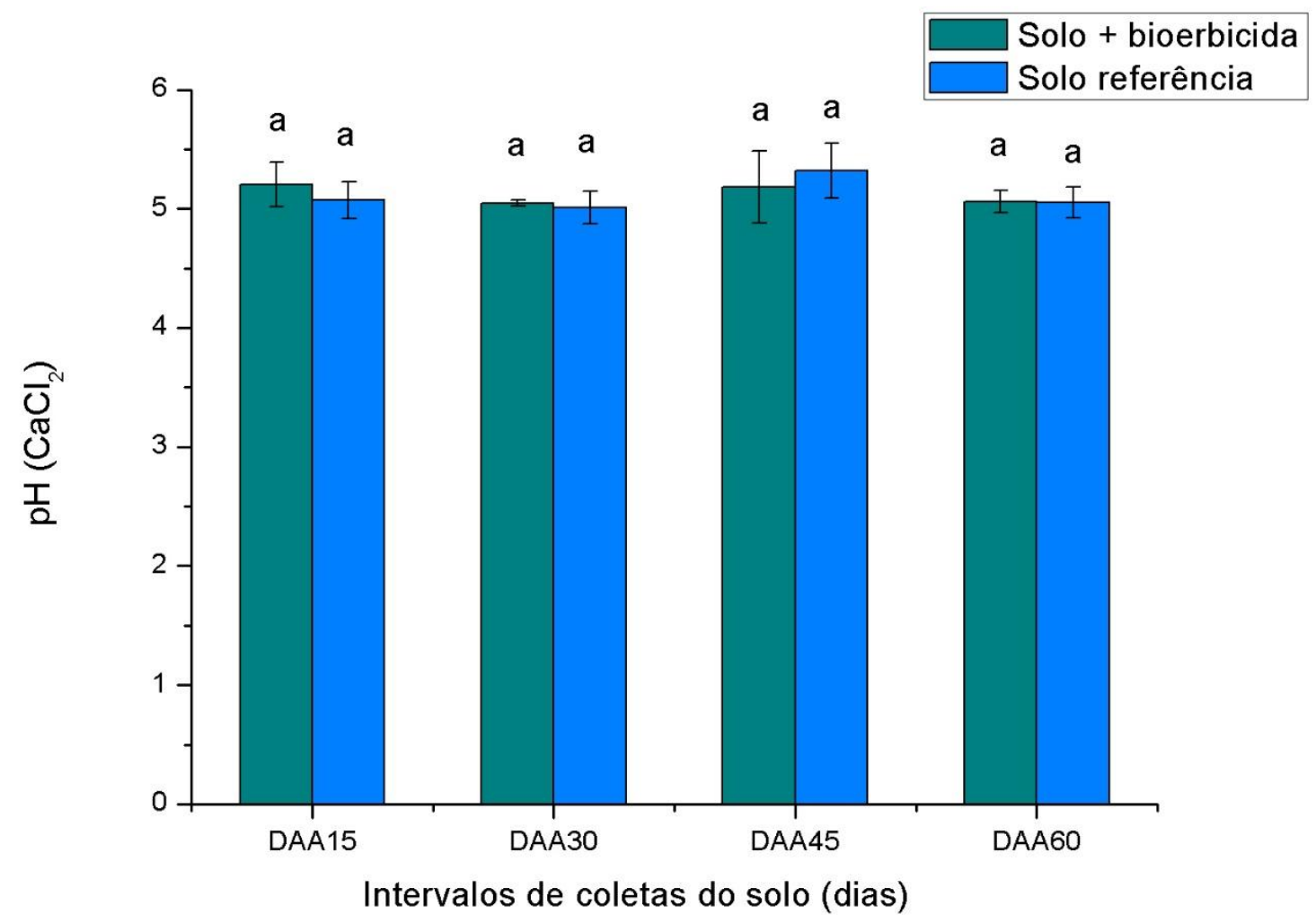

$\mathrm{O}$ pH fornece indícios das condições químicas gerais do solo. Solos com acidez elevada, geralmente são solos pobres em bases (cálcio e magnésio, principalmente), elevado teor de alumínio tóxico; alta fixação de fósforo e deficiência de alguns micronutrientes. Solos brasileiros são, em sua maioria, ácidos com níveis de Mn e Al tóxicos, baixos níveis de macronutrientes como cálcio e magnésio e baixo nível de fósforo disponível (CAIRES et al., 2008). 
Para as medidas do potencial hidrogeniônico $(\mathrm{pH})$ em água, foi observada diferença estatística apenas na análise do solo aos DAA30, sendo que para as demais etapas de avaliação, os valores obtidos do solo sujeito a ação do bioerbicida e do solo referência foram estatisticamente iguais.

Das medidas de pH em cloreto de cálcio, entre todas as etapas de avaliação (solo e solo referência), não houve diferença estatística entre as médias, ou seja, em ambos, o solo sujeito ao bioerbicida e o solo sem aplicação deste, os valores médios obtidos foram estatisticamente iguais. A Tabela 36 apresentam os valores médios de $\mathrm{pH}$ (água e $\mathrm{CaCl}_{2}$ ) do solo e a análise de variância (ANOVA) dos dados durante as etapas de aplicação e incorporação do bioerbicida em estudo em comparação ao vaso de referência.

Tabela 36 - Valores de $\mathrm{pH}$ do solo ao longo do experimento com a planta Sida spinosa.

\begin{tabular}{lllll}
\hline $\begin{array}{l}\text { Etapa de análise } \\
\text { do solo (dias) }\end{array}$ & $\mathrm{pH}$ (água) & $\mathrm{pH}$ (água) & $\mathrm{pH}\left(\mathrm{CaCl}_{2}\right)$ & $\mathrm{pH}\left(\mathrm{CaCl}_{2}\right)$ \\
\hline DAA15 & $5,86 \pm 0,05 \mathbf{a}$ & $5,89 \pm 0,04 \mathbf{a}$ & $5,20 \pm 0,18 \mathbf{a}$ & $5,10 \pm 0,04 \mathbf{a}$ \\
DAA30 & $5,80 \pm 0,06 \mathbf{a}$ & $5,64 \pm 0,06 \mathbf{b}$ & $5,04 \pm 0,02 \mathbf{a}$ & $5,04 \pm 0,03 \mathbf{a}$ \\
DAA45 & $5,53 \pm 0,34 \mathbf{a}$ & $5,60 \pm 0,06 \mathbf{a}$ & $5,18 \pm 0,30 \mathbf{a}$ & $5,28 \pm 0,04 \mathbf{a}$ \\
DAA60 & $5,32 \pm 0,20 \mathbf{a}$ & $5,54 \pm 0,06 \mathbf{a}$ & $5,06 \pm 0,09 \mathbf{a}$ & $5,05 \pm 0,04 \mathbf{a}$
\end{tabular}

*Vaso referência. Médias seguidas pela mesma letra na linha não diferem significativamente entre si pelo teste de Tukey $(P<0,05)$. $(\mathrm{n}=3)$.

\subsubsection{Capacidade de troca catiônica (CTC)}

A Figura 50 apresentam as análises da capacidade de troca catiônica (CTC) do solo durante as etapas de aplicação e incorporação do bioerbicida em estudo em comparação ao solo referência. 
Figura 50 - Capacidade de troca catiônica no solo após incorporação do bioerbicida, na $1^{\mathrm{a}}, 2^{\mathrm{a}}$, $3^{\mathrm{a}}$ e $4^{\mathrm{a}}$ aplicação. Médias seguidas pela mesma letra na coluna não diferem significativamente entre si pelo teste de Tukey $(P<0,05)$.

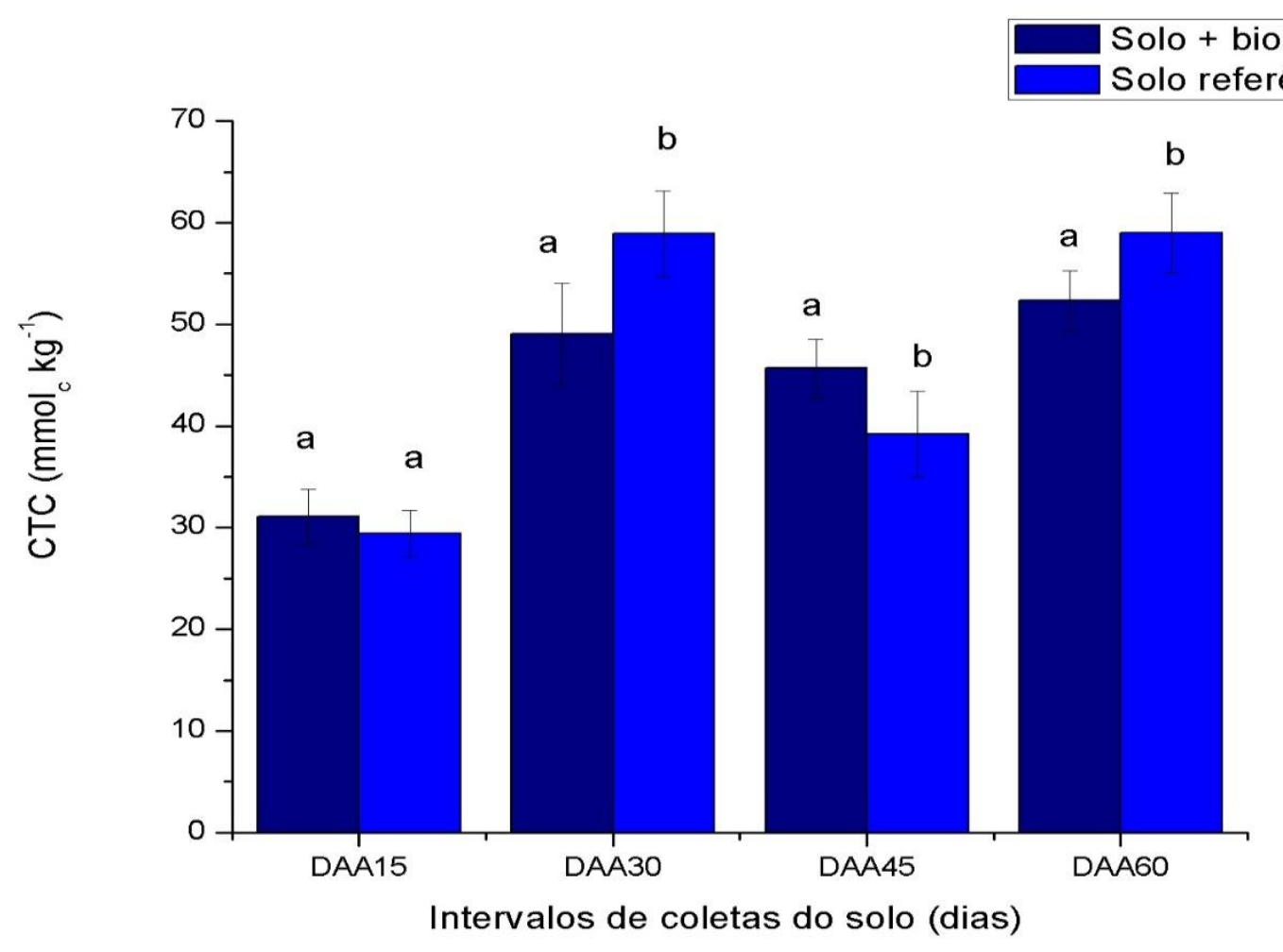

Nos tempos de coleta referentes $2^{\mathrm{a}}, 3^{\mathrm{a}}$ e $4^{\mathrm{a}}$ aplicação, as médias entre o solo e o solo referência apresentaram diferença estatística. Apesar do solo referência não receber a aplicação do bioerbicida, a questão da disponibilidade de nutrientes está ligada à quantidade de organismos presentes, ou seja, está relacionada às plantas que se desenvolvem e as com desenvolvimento tardio dentro da quantidade de plantas inicialmente plantadas (10 plantas de soja para 10 plantas da invasora). Em outras palavras, a capacidade de troca catiônica do solo é um mecanismo de liberação de nutrientes que é controlado pelo solo e depende da necessidade nutricional e da quantidade de plantas no sistema. A análise do solo aos DAA15 não apresentou diferença significativa, provavelmente pelo fato de que nesta etapa de análise, em ambos os casos, a necessidade e disponibilidade nutricional eram as mesmas, já que o processo inibitório ocasionado pela ação do bioerbicida é observado nas etapas seguintes do experimento, etapas estas em que as plantas invasoras sujeitas à ação do bioerbicida possivelmente já não necessitam dos mesmos níveis de nutrientes. A Tabela 37 apresenta os valores médios da CTC do solo e a análise de variância (ANOVA) estatística dos dados durante as etapas de aplicação e incorporação do bioerbicida em estudo em comparação ao vaso de referência. 
Tabela 37 - Teores da capacidade de troca catiônica (CTC) do solo ao longo do experimento com a planta Sida spinosa.

\begin{tabular}{lll}
\hline Coletas (dias) & CTC $\left(\mathrm{mmol}_{\mathrm{c} \mathrm{kg}}{ }^{-1}\right)$ & $\mathrm{CTC}^{*}\left(\mathrm{mmol}_{\mathrm{c}} \mathrm{kg}^{-1}\right)$ \\
\hline DAA15 & $31,06 \pm 2,71 \mathbf{a}$ & $28,50 \pm 0,90 \mathbf{a}$ \\
DAA30 & $49,03 \pm 5,00 \mathbf{a}$ & $57,50 \pm 1,45 \mathbf{b}$ \\
DAA45 & $45,69 \pm 2,87 \mathbf{a}$ & $39,20 \pm 1,75 \mathbf{b}$ \\
DAA60 & $52,36 \pm 2,90 \mathbf{a}$ & $57,80 \pm 0,98 \mathbf{b}$
\end{tabular}

*Vaso referência. Médias seguidas pela mesma letra na linha não diferem significativamente entre si pelo teste de Tukey $(P<0,05)$. $(\mathrm{n}=3)$.

Em geral, as variações nos teores de CTC não indicaram um prejuízo causado pelo contato dos extratos no solo, já que não houve uma diminuição proporcional da CTC com o aumento do número de aplicações dos extratos.

\subsubsection{Cálcio e potássio}

As Figuras 51 e 52 apresentam os teores de cálcio e potássio do solo durante as etapas de aplicação e incorporação do bioerbicida em estudo em comparação ao solo referência.

Figura 51 - Teor de cálcio no solo após incorporação do bioerbicida, na $1^{\mathrm{a}}, 2^{\mathrm{a}}, 3^{\mathrm{a}}$ e $4^{\mathrm{a}}$ aplicação. Médias seguidas pela mesma letra na coluna não diferem significativamente entre si pelo teste de Tukey $(P<0,05)$.

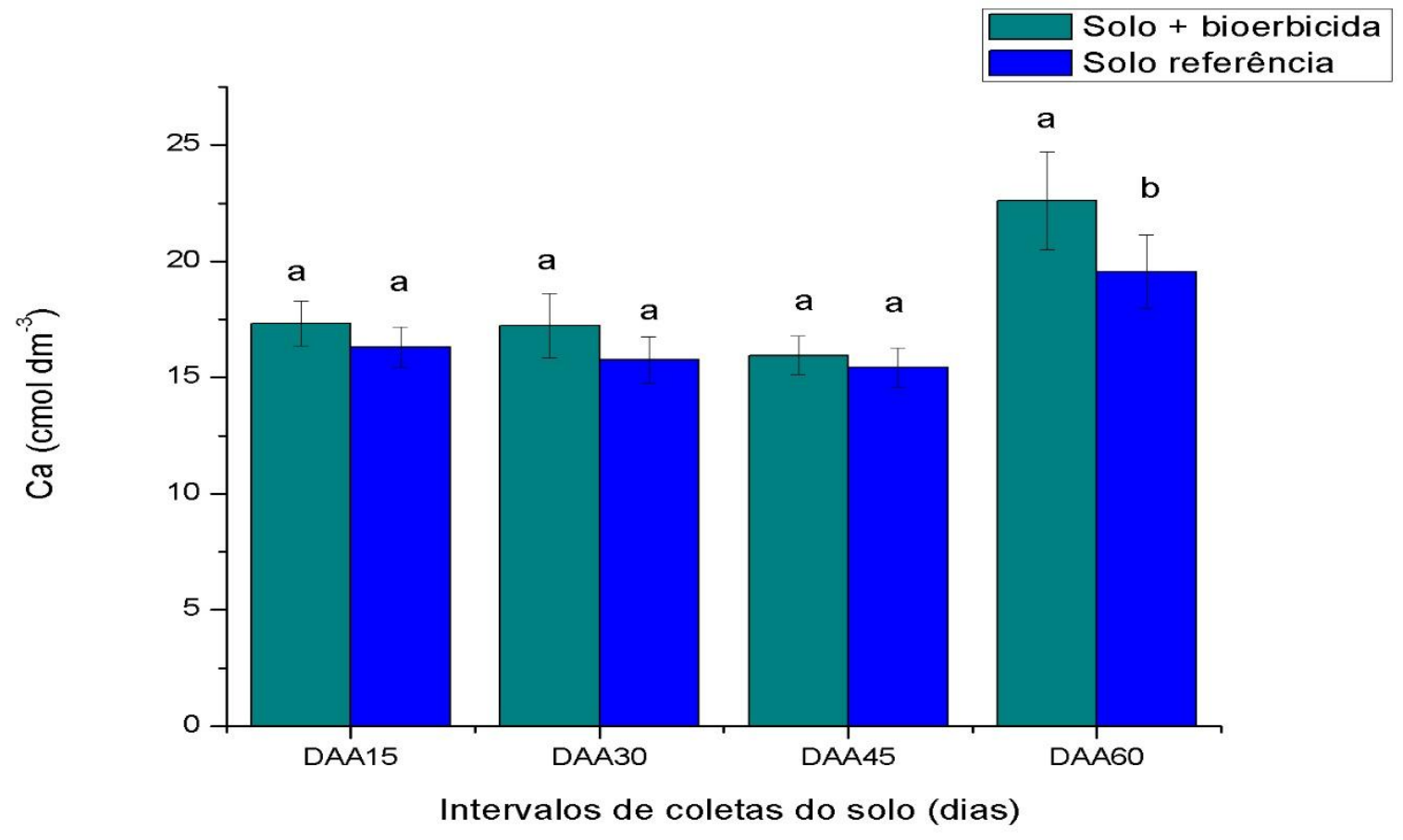


Figura 52 - Teor de potássio no solo após incorporação do bioerbicida, na $1^{\mathrm{a}}, 2^{\mathrm{a}}, 3^{\mathrm{a}}$ e $4^{\mathrm{a}}$ aplicação. Médias seguidas pela mesma letra na coluna não diferem significativamente entre si pelo teste de Tukey $(P<0,05)$.

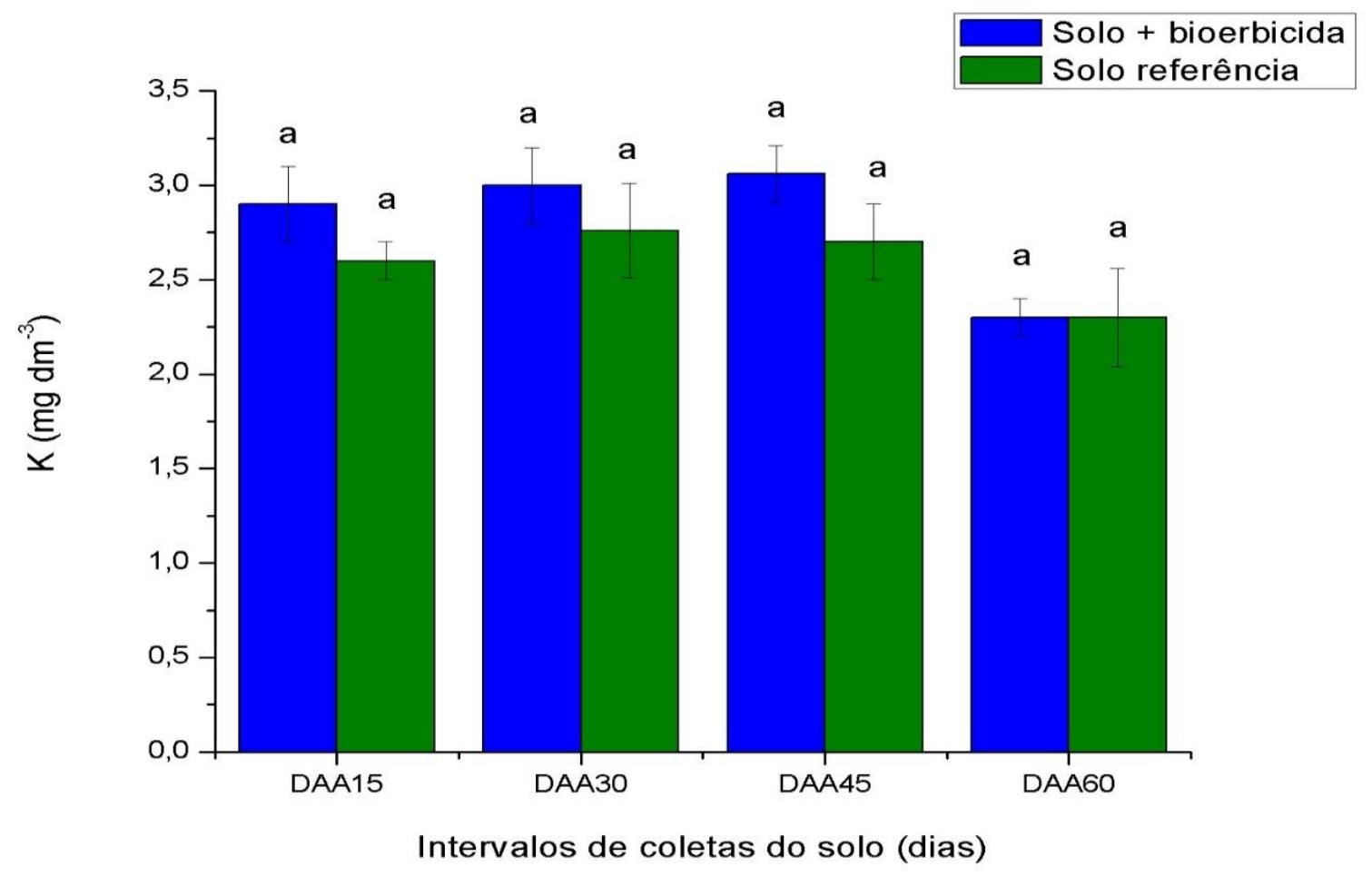

A análise do elemento potássio não apresentou diferença estatística em comparação à referência ao longo do experimento. O potássio é um elemento que se encontra livre na célula (na forma iônica), acumula-se no início do desenvolvimento da planta, sendo liberado quando a planta envelhece. Assim, não há a ideia de consumo gradual deste nutriente, paralelamente ao desenvolvimento, já que este elemento não é utilizado desta forma pelas plantas.

Para as análises do elemento cálcio, entre todas as determinações (solo e solo referência), a diferença estatística entre as médias foi observada apenas na etapa de coleta do solo aos DAA60. A diferença nos níveis mais baixos de cálcio entre o vaso referência e o vaso sujeito a ação do bioerbicida, mostra que nesta etapa do experimento o solo do vaso referência apresentava ainda um consumo deste elemento, já que existiam plantas em desenvolvimento. As sucessivas aplicações do bioerbicida e a avaliação do sistema nesta etapa do experimento $\left(60^{\circ} \mathrm{dia}\right)$ mostraram que as plantas invasoras já estavam mortas e/ou com o desenvolvimento inferior às plantas do vaso de referência, assim, os níveis mais altos do elemento cálcio no vaso em experimento com o bioerbicida indicam que nestas condições o consumo de nutrientes não é necessário, pois o desenvolvimento das plantas já foi prejudicado. 
O cálcio desempenha um papel nutritivo vital na produção de vários cultivos. Age também como corretor de solos em algumas situações. Nas plantas, o cálcio é classificado como um nutriente secundário que é necessário em grandes quantidades na forma de $\mathrm{Ca}^{2+}$.

O cálcio desempenha um papel principal na estrutura na parede celular e na integridade da membrana. Além disso, para a estabilidade das plantas, uma parede celular forte ajuda a prevenir a invasão de inúmeros fungos e bactérias. O cálcio também promove o prolongamento das células, participando de processos enzimáticos e hormonais, desempenhando também papel nos processos de absorção de outros nutrientes.

A quantidade total de cálcio está normalmente na faixa de 0,7 a 1,5\% em solos de clima temperado. Solos tropicais tipicamente tem baixo teor de cálcio $(0,1$ a $0,3 \%)$, enquanto solos calcários podem conter até $25 \%$ de Ca. A solubilidade de cálcio depende de vários fatores do solo, como: pH, solos mais básicos normalmente contêm mais Ca disponível nos sítios de troca de cátions; capacidade de troca catiônica (CTC), a disponibilidade do Ca é afetada pela capacidade de troca de cátions e pela saturação dos sítios de troca catiônica; presença de outros cátions no solo, o cálcio é preferencialmente adsorvido nos sítios de troca catiônica, sua solubilidade e disponibilidade na planta são influenciadas por outros cátions no solo (IPNI, 2015). A Tabela 38 apresenta os valores médios de cálcio e potássio do solo durante as etapas de aplicação e incorporação do bioerbicida em estudo em comparação ao solo referência.

Tabela 38 - Teores de cálcio e potássio no solo ao longo do experimento com a planta Sida spinosa.

\begin{tabular}{lllll}
\hline Coletas (dias) & $\begin{array}{l}\text { Cálcio } \\
\left(\mathrm{cmol} \mathrm{dm}^{-3}\right)\end{array}$ & $\begin{array}{l}\text { Cálcio* } \\
\left(\mathrm{cmol} \mathrm{dm}^{-3}\right)\end{array}$ & $\begin{array}{l}\text { Potássio } \\
\left(\mathrm{mg} \mathrm{dm}^{-3}\right)\end{array}$ & $\begin{array}{l}\text { Potássio* } \\
\left(\mathrm{mg} \mathrm{dm}^{-3}\right)\end{array}$ \\
\hline DAA15 & $17,32 \pm 0,95 \mathbf{a}$ & $22,65 \pm 0,87 \mathbf{a}$ & $2,90 \pm 0,20 \mathbf{a}$ & $2,60 \pm 0,10 \mathbf{a}$ \\
DAA30 & $17,24 \pm 1,38 \mathbf{a}$ & $15,76 \pm 0,98 \mathbf{a}$ & $3,00 \pm 0,20 \mathbf{a}$ & $2,76 \pm 0,25 \mathbf{a}$ \\
DAA45 & $15,95 \pm 0,83 \mathbf{a}$ & $15,44 \pm 0,84 \mathbf{a}$ & $3,06 \pm 0,15 \mathbf{a}$ & $2,70 \pm 0,20 \mathbf{a}$ \\
DAA60 & $22,60 \pm 2,10 \mathbf{a}$ & $19,56 \pm 1,56 \mathbf{b}$ & $2,30 \pm 0,10 \mathbf{a}$ & $2,30 \pm 0,26 \mathbf{a}$
\end{tabular}

*Vaso referência. Médias seguidas pela mesma letra na linha não diferem significativamente entre si pelo teste de Tukey $(P<0,05)$. $(\mathrm{n}=3)$.

Em geral, pode ser dito que a ação dos extratos não causou interferência na disponibilidade de cálcio e potássio, já que os teores obtidos foram estatisticamente iguais. 


\subsubsection{Fósforo disponível}

A Figura 53 apresenta as análises de fósforo disponível do solo durante as etapas de aplicação e incorporação do bioerbicida em estudo em comparação ao vaso de referência.

Figura 53 - Fósforo disponível no solo após incorporação do bioerbicida, na $1^{\mathrm{a}}, 2^{\mathrm{a}}, 3^{\mathrm{a}}$ e $4^{\mathrm{a}}$ aplicação. Médias seguidas pela mesma letra na coluna não diferem significativamente entre si pelo teste de Tukey $(P<0,05)$.

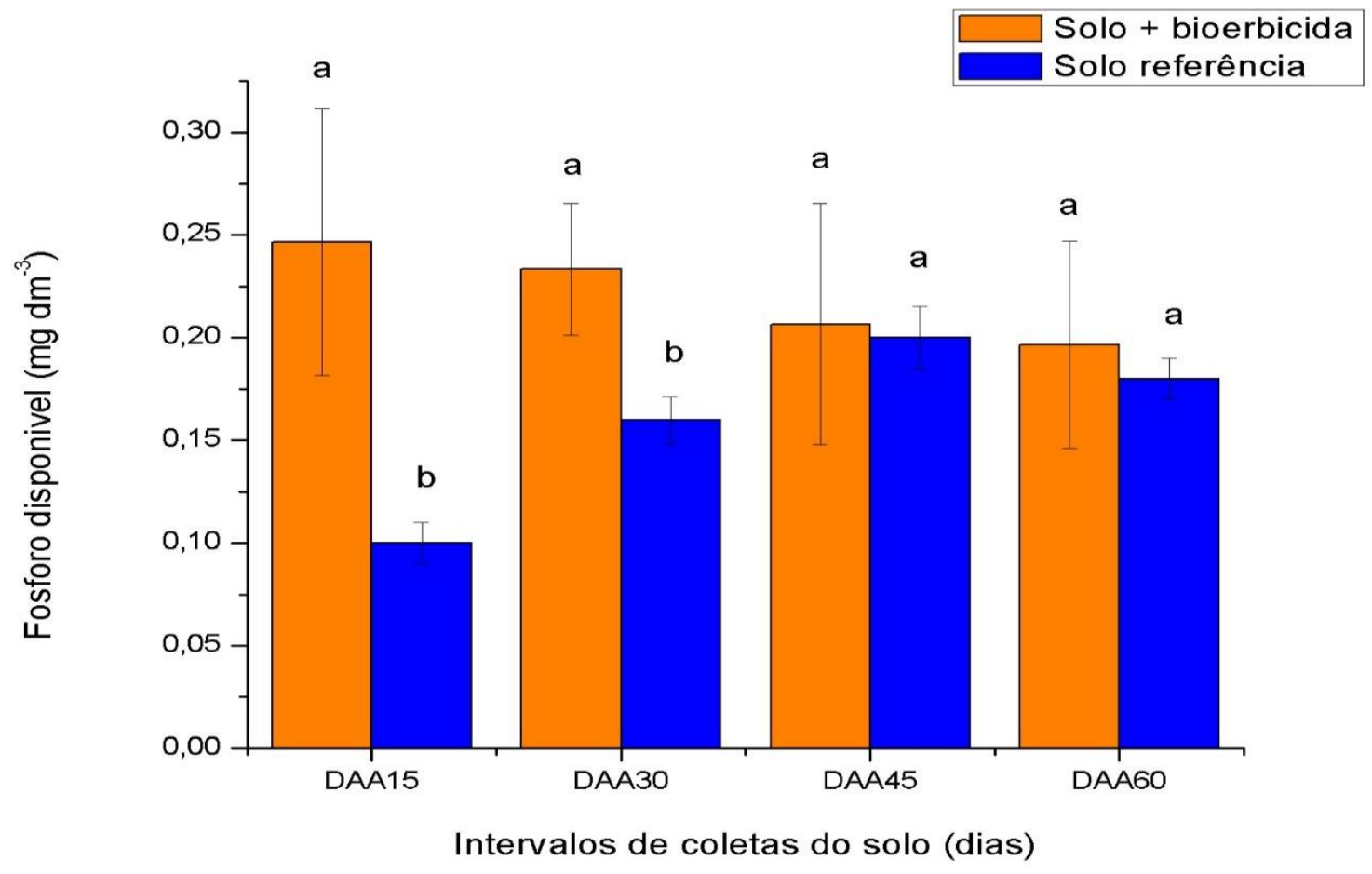

As análises do solo quanto ao teor de fósforo disponível apresentaram diferenças significativas entre si (no mesmo intervalo de coleta) apenas nos períodos iniciais de avaliação do solo. Inicialmente, levando-se em consideração o porte das plantas nesta etapa de análise, pode-se dizer que as plantas presentes no vaso referência estavam se desenvolvendo melhor, consequentemente absorvendo mais nutrientes do solo. Esse fato, pode ser exemplificado pelas médias menores em relação aos vasos sob ação do bioerbicida, ou seja, valores menores determinados no mesmo período mostram que as plantas sujeitas a ação dos extratos sofrem uma deficiência na absorção de nutrientes do solo em relação às plantas cultivadas sem aplicação dos extratos. Uma possível explicação para a igualdade de médias nos tempos DAA45 e DAA60 estaria no fato que as plantas invasoras já estavam em processo de inibição e a morte da planta era evidente, em outras palavras, já estavam sendo combatidas e o consumo deste 
nutriente era irrelevante. Já nos vasos de referência, havia um bom desenvolvimento e estavam bem estabelecidas no solo, não havendo mais consumo deste nutriente. A Tabela 39 apresenta os valores médios de fósforo disponível do solo durante as etapas de aplicação e incorporação do bioerbicida em estudo em comparação ao vaso de referência.

Tabela 39 - Teor de fósforo disponível no solo ao longo do experimento com a planta Sida spinosa.

\begin{tabular}{lll}
\hline Coletas (dias) & $\begin{array}{l}\text { Fósforo disponível } \\
\left(\mathrm{mg} \mathrm{dm}^{-3}\right)\end{array}$ & $\begin{array}{l}\text { Fósforo disponível* } \\
\left(\mathrm{mg} \mathrm{dm}^{-3}\right)\end{array}$ \\
\hline DAA15 & $0,24 \pm 0,06 \mathbf{a}$ & $0,11 \pm 0,01 \mathbf{b}$ \\
DAA30 & $0,23 \pm 0,03 \mathbf{a}$ & $0,15 \pm 0,01 \mathbf{b}$ \\
DAA45 & $0,20 \pm 0,06 \mathbf{a}$ & $0,19 \pm 0,01 \mathbf{a}$ \\
DAA60 & $0,19 \pm 0,05 \mathbf{a}$ & $0,18 \pm 0,01 \mathbf{a}$
\end{tabular}

*Vaso referência. Médias seguidas pela mesma letra na linha não diferem significativamente entre si pelo teste de Tukey $(P<0,05)$. $(\mathrm{n}=3)$.

Numericamente, pode ser visto que os valores do fósforo disponível no solo (vaso referência) foram menores, demonstrando a possível disponibilidade deste às plantas que não foram sujeitas a ação dos extratos, indicando uma possível relação entre a absorção de nutrientes e o contato do bioerbicida. Outra justificativa pode ser feita relacionando-se a CTC do solo à disponibilidade do fósforo no solo, onde se pode inferir que a ação dos extratos no sistema e, consequentemente, contato com o solo diminui a fertilidade do solo, conforme já discutido no item 4.5.6.

\subsubsection{Nitrogênio}

A Figura 54 apresentam as análises de nitrogênio do solo durante as etapas de aplicação e incorporação do bioerbicida em estudo em comparação ao vaso referência. 
Figura 54 - Teor de nitrogênio no solo após incorporação do bioerbicida, na $1^{\mathrm{a}}, 2^{\mathrm{a}}, 3^{\mathrm{a}}$ e $4^{\mathrm{a}}$ aplicação. Médias seguidas pela mesma letra na coluna não diferem significativamente entre si pelo teste de Tukey $(P<0,05)$.

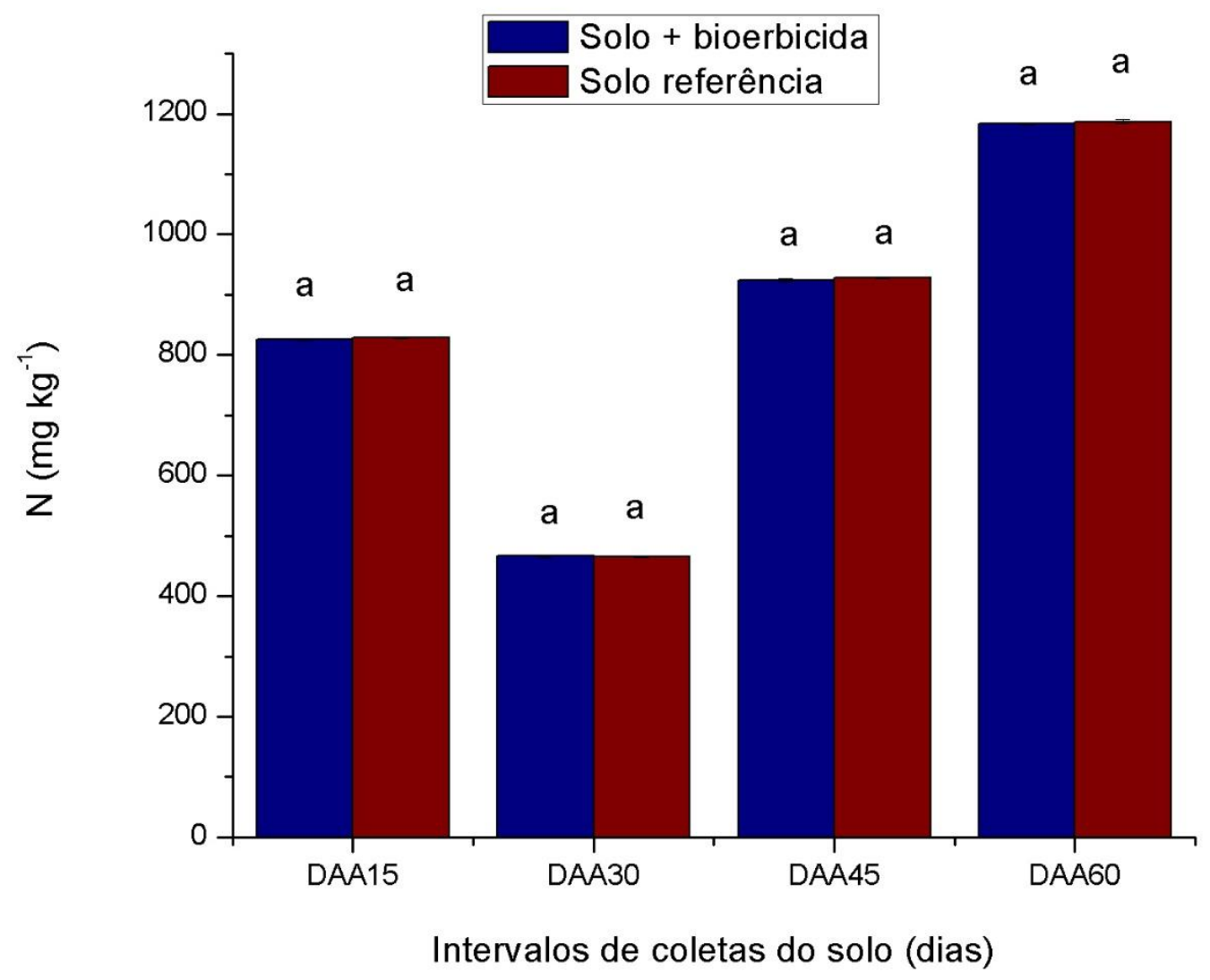

Estatisticamente, entre todas as determinações (solo e solo referência), não houve diferença entre as médias. Considerando-se o ciclo de nitrogênio e o consumo deste nutriente pelas plantas pode-se dizer que apesar das sucessivas aplicações do bioerbicida nas plantas invasoras os níveis de nitrogênio foram iguais ao vaso referência, isto provavelmente devido ao fato de que em ambos os sistemas havia plantas de soja + plantas invasoras, sendo que a soja, isenta da ação do bioerbicida, utiliza o nitrogênio do solo no seu desenvolvimento.

Nas plantas, o nitrogênio é exigido em maior quantidade pelas culturas do que qualquer outro nutriente essencial, com exceção do potássio. Algumas culturas necessitam mais do potássio do que do nitrogênio. Em solo, a quantidade de nitrogênio presente na matéria orgânica é grande, mas a quantidade disponível paras absorção pelas plantas é relativamente pequena. Pouco N é encontrado em rochas e minerais. A matéria orgânica libera lentamente nitrogênio, esta taxa de liberação é controlada pela atividade microbiana do solo, influenciada pela temperatura, umidade, $\mathrm{pH}$ e pela textura do solo (IPNI, 2015). A Tabela 40 apresenta os valores 
médios de nitrogênio no solo durante as etapas de aplicação e incorporação do bioerbicida em estudo em comparação ao vaso de referência.

Tabela 40 - Teor de nitrogênio no solo ao longo do experimento com a planta Sida spinosa. Coletas (dias) Nitrogênio $\left(\mathrm{mg} \mathrm{kg}^{-1}\right) \quad$ Nitrogênio* $\left(\mathrm{mg} \mathrm{kg}^{-1}\right)$

\begin{tabular}{lrr}
\hline DAA15 & $825,66 \pm 2,08 \mathbf{a}$ & $828,33 \pm 1,53 \mathbf{a}$ \\
DAA30 & $466,33 \pm 1,52 \mathbf{a}$ & $465,33 \pm 1,53 \mathbf{a}$ \\
DAA45 & $924,33 \pm 2,52 \mathbf{a}$ & $928,33 \pm 1,54 \mathbf{a}$ \\
DAA60 & $1184,33 \pm 1,53 \mathbf{a}$ & $1187,33 \pm 3,60 \mathbf{a}$
\end{tabular}

*Vaso referência. Médias seguidas pela mesma letra na linha não diferem significativamente entre si pelo teste de Tukey $(P<0,05)$. $(\mathrm{n}=3)$.

Numericamente, os teores de nitrogênio em ambos os solos apresentaram valores bem próximos, logo, podemos dizer que o possível contato dos extratos não alterou as características do solo.

\subsubsection{Acidez trocável}

A Figura 55 apresenta as análises da acidez trocável do solo durante as etapas de aplicação e incorporação do bioerbicida em estudo em comparação ao vaso de referência. 
Figura 55 - Acidez trocável do solo após incorporação do bioerbicida, na $1^{\mathrm{a}}, 2^{\mathrm{a}}, 3^{\mathrm{a}}$ e $4^{\mathrm{a}}$ aplicação. Médias seguidas pela mesma letra na coluna não diferem significativamente entre si pelo teste de Tukey $(P<0,05)$.

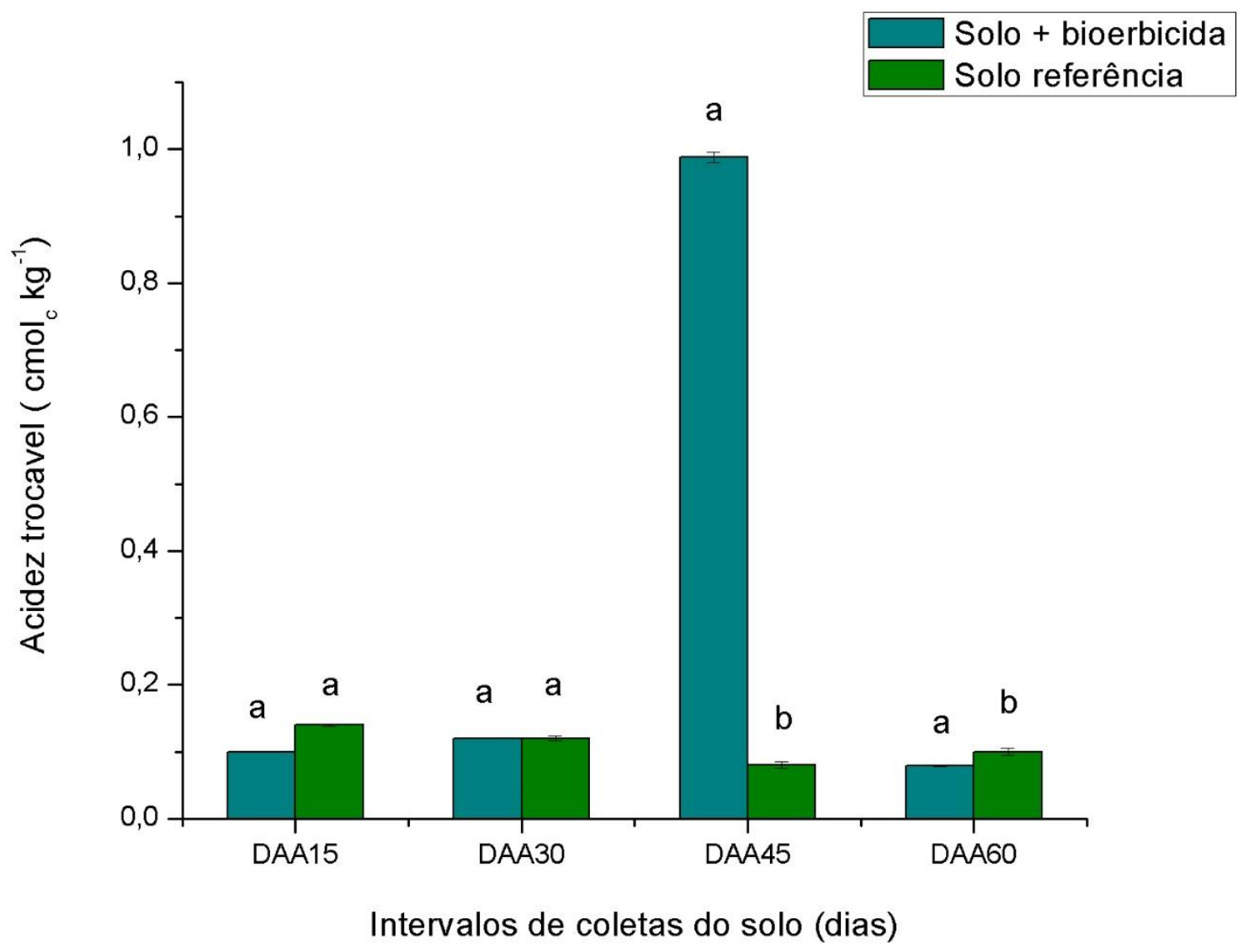

De acordo com a análise de variância dos dados das determinações entre o solo e o solo de referência as diferenças estatísticas foram notadas nas análises do solo aos DAA45 e DAA60, sendo que na análise do solo aos 45 dias após aplicação do bioerbicida ( $3^{\text {a }}$ aplicação), os níveis da acidez do solo foram mais altos em comparação aos demais, sendo esta observação, um indício da ação do bioerbicida no solo.

Em qualquer experimento existe um limite mínimo de detecção de efeitos; desse modo a ausência de significância estatística não pode ser tomada como sinônimo de ausência de efeito. O que pode ser dito, é que em torno de 30 dias (do DAA15 ao DAA45) o bioerbicida utilizado foi capaz de se acumular no solo, por meio das aplicações do mesmo. Em geral, a planta invasora em estudo (Sida spinosa) não apresentou um grande porte na etapa em que se iniciaram as aplicações.

Considerando-se o sistema composto por planta invasora + soja, e o porte das plantas invasoras presentes, em outras palavras, a área superficial a ser atingida por pulverização do 
bioerbicida na planta, é possível dizer que as aplicações feitas em, no mínimo, 5 plantas, tendo como base um volume de aplicação de $3 \mathrm{~mL}$ por planta, o volume total de extrato que provavelmente atingiu o solo até esta etapa de avaliação (DAA45) foi de aproximadamente 45 $\mathrm{mL}$, o qual pode ter contribuído para o aumento dos níveis da acidez no solo. O possível efeito deletério do bioerbicida às características do solo pode estar relacionada à baixa atividade da microbiota, o que possivelmente diminuiria a toxicidade no solo, já que fungos micorrízicos são capazes de degradar compostos fenólicos.

A acidez no solo diminui a população de micro-organismos que são responsáveis pela decomposição da matéria orgânica. Além disso, em solos ácidos, a CTC é baixa, o Ca e o Mg são limitantes, assim como a disponibilidade do P. Considerando-se que o solo utilizado não sofreu nenhum preparo e por apresentar níveis baixos de matéria orgânica, pode-se dizer que nestas condições, o contato do bioerbicida no solo não sofreu ação de micro-organismos que degradassem o princípio ativo e mascarassem a alteração da acidez. De acordo com Oliveira e Brighenti (2011), a adição de matéria orgânica e fertilizantes aumenta a atividade biológica dos solos, aumentando a degradação de compostos com características herbicidas.

A aplicação de fertilizantes não afeta apenas as plantas, mas também pode ter impactos sobre a população microbiana no solo. Segundo Linderman e Davis (2004), a aplicação controlada de fertilizantes com alto teor de fósforo elimina a colonização de fungos de micorriza arbuscular, considerando que fertilizantes orgânicos com baixo teor de fósforo apenas reduzem a colonização sem eliminá-la por completo (BAILEY et al., 2013).

No sistema plantio direto, a acidificação do meio é caracterizada pelo menor $\mathrm{pH}$ da camada superficial do solo. Alterações de pH no solo em sistema plantio direto afetam a solubilidade do alumínio, alterando sua absorção pelas plantas. Por outro lado, o aumento dos níveis de matéria orgânica neste sistema podem promover a redução da toxicidade do alumínio devido ao fenômeno de complexação de superfície e de complexação na solução de solo. O alumínio interage com os ácidos orgânicos de baixa massa molecular, ácidos húmicos e ácidos fúlvicos para formar complexos orgânicos solúveis ou insolúveis, dependendo do tipo de ácido e do pH do meio (ZAMBROSI, ALLEONI; CAIRES, 2007).

Estudos de solos com compostos alelopáticos sugerem que os fatores do solo como argila, óxidos, matéria orgânica, $\mathrm{pH}$, nutrientes e microbiotas têm um papel importante na concentração ativa destes compostos no solo (OLIVEIRA; BRIGHENTI, 2011; ZAMBROSI, ALLEONI; CAIRES, 2007). Logo, podemos dizer que a incorporação dos extratos em um solo (com baixa atividade microbiana) associados aos níveis baixos de matéria orgânica promove o aumento da toxidez do alumínio no solo. 
A Tabela 41 apresenta os valores médios de acidez trocável do solo durante as etapas de aplicação e incorporação do bioerbicida em estudo em comparação ao vaso de referência.

Tabela 41 - Teor de acidez trocável e porcentagem de saturação por alumínio (m\%) no solo ao longo do experimento com a planta Sida spinosa.

\begin{tabular}{llclc}
\hline Coletas (dias) & $\begin{array}{l}\text { Acidez trocável } \\
\left(\mathrm{cmol}_{\mathrm{c}} \mathrm{kg}^{-1}\right)\end{array}$ & $\mathrm{m} \%$ & $\begin{array}{l}\text { Acidez trocável* } \\
\left(\mathrm{cmol}_{\mathrm{c}} \mathrm{kg}^{-1}\right)\end{array}$ & $\mathrm{m} \%$ \\
\hline DAA15 & $0,09 \pm 1,15 \mathrm{E}-4 \mathbf{a}$ & 2,9 & $0,12 \pm 0,01 \mathbf{a}$ & 4,2 \\
DAA30 & $0,11 \pm 1,05 \mathrm{E}-4 \mathbf{a}$ & 2,2 & $0,10 \pm 0,01 \mathbf{a}$ & 1,7 \\
DAA45 & $0,98 \pm 0,007 \mathbf{a}$ & 21,4 & $0,09 \pm 0,01 \mathbf{b}$ & 2,2 \\
DAA60 & $0,08 \pm 0,001 \mathbf{a}$ & 1,5 & $0,02 \pm 0,01 \mathbf{b}$ & 0,3
\end{tabular}

*Vaso referência. Médias seguidas pela mesma letra na linha não diferem significativamente entre si pelo teste de Tukey $(P<0,05)$. $(\mathrm{n}=3)$.

A Tabela 42 mostra a classificação de toxicidade de acordo com os valores de porcentagem de saturação por alumínio no solo.

Tabela 42 - Interpretação dos valores de alumínio no solo (m\%). Segundo Osaki (1991).

\begin{tabular}{ll}
\hline $\mathrm{m} \% *$ & Classificação \\
\hline$<5$ & Muito baixo (não prejudicial) \\
$5-10$ & Baixo (pouco prejudicial) \\
$10,1-20$ & Médio (medianamente prejudicial) \\
$20,1-45$ & Alto (prejudicial) \\
$>45$ & Muito alto (altamente prejudicial) \\
\hline
\end{tabular}

$* \mathrm{~m} \%=\left[\mathrm{mmol}_{\mathrm{c}} \mathrm{kg}^{-1}(\mathrm{H}+\mathrm{Al}) \mathrm{x} \mathrm{100]} /\left[\mathrm{mmolc} \mathrm{kg}^{-1}(\mathrm{CTC})\right]\right.$.

Os valores numéricos mostram que a acidez no solo aos DAA45 foi aproximadamente 8 vezes maior em relação aos valores obtidos após a primeira etapa de aplicação do bioerbicida. O valor obtido para a porcentagem de saturação por alumínio $\left(21,4 \mathrm{cmol}_{\mathrm{c}} \mathrm{kg}^{-1}\right)$ foi alto indicando que houve um possível prejuízo ao solo. Analisando-se os dados do solo sob ação do bioerbicida é possível concluir que a persistência dos extratos está dentro do intervalo de 15 dias, como pode ser observado do DAA 45, onde a porcentagem de saturação por alumínio apresentou-se alta, ao DAA60, onde a porcentagem de saturação por alumínio voltou a níveis muitos baixos $\left(1,5 \mathrm{cmol}_{\mathrm{c}} \mathrm{kg}^{-1}\right)$. Logo, por se tratar de um composto natural, o processo de 
degradação do bioerbicida no solo pode ter sido causado por fatores externos como a temperatura.

\subsubsection{Carbono orgânico total}

A Figuras 56 apresenta as análises de carbono orgânico total do solo, durante as etapas de aplicação e incorporação do bioerbicida em estudo em comparação ao vaso referência.

Figura 56 - Teor de carbono orgânico no solo após incorporação do bioerbicida, na $1^{\mathrm{a}}, 2^{\mathrm{a}}, 3^{\mathrm{a}} \mathrm{e}$ $4^{\mathrm{a}}$ aplicação. Médias seguidas pela mesma letra na coluna não diferem significativamente entre si pelo teste de Tukey $(P<0,05)$.

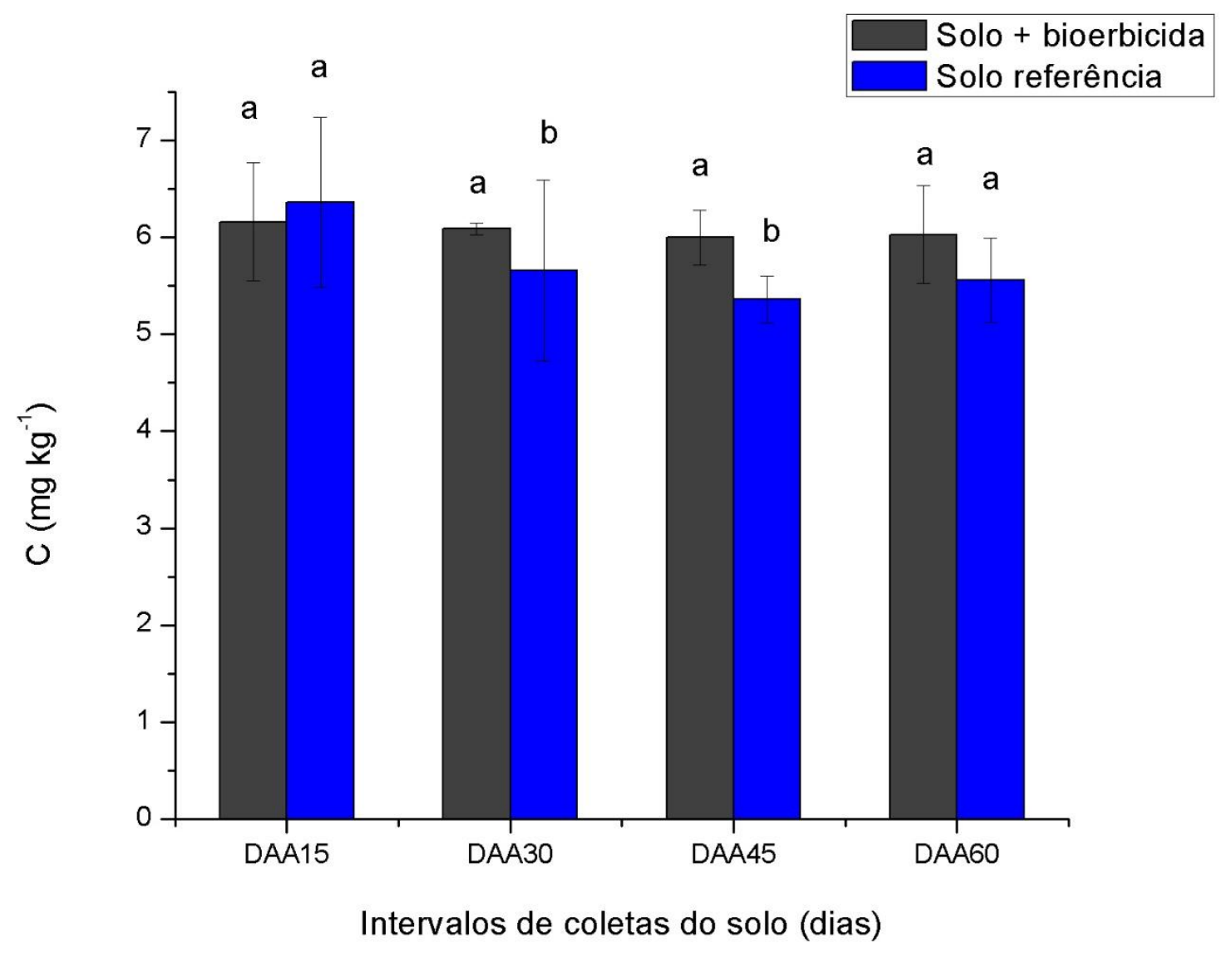


De acordo com os dados obtidos, as diferenças estatísticas entre as determinações foram notadas nos intervalos de coleta referente ao $30^{\circ}$ e $45^{\circ}$ dia de coleta do solo, sendo que os vasos sujeitos à aplicação dos extratos (nestas etapas de análise) apresentaram níveis de carbono mais altos em relação ao sistema que não recebeu a ação dos extratos.

O solo é uma das ferramentas capazes de sequestrar carbono da atmosfera, tornando-se assim uma forma de atenuar o aumento das concentrações de gases do efeito estufa. A atmosfera é o menor e o mais dinâmico dos reservatórios do ciclo de carbono. Entretanto, todas a mudanças que ocorrem na atmosfera tem relação com as mudanças do ciclo global de carbono e do clima. Grande parte do carbono presente na atmosfera ocorre na forma de dióxido de carbono. Qualquer atividade relacionada ao uso da terra que modifique a quantidade de biomassa na vegetação e no solo tem potencial de alterar a quantidade de carbono armazenada (ROSA; SANO; ROSENDO, 2014). Logo, os níveis de carbono no sistema que recebia o tratamento com o bioerbicida estão relacionadas ao desenvolvimento das plantas no meio, no caso, as plantas invasoras do sistema estavam em constante processo de inibição, não necessitando assim da absorção do carbono presente no solo, já que seu desenvolvimento estaria prejudicado. Já na análise do solo nos vasos de referência, os níveis mais baixos condizem com a ideia de consumo deste elemento, já que as plantas no sistema estavam se desenvolvendo sem a ação dos extratos. A Tabela 43 apresenta os valores médios de carbono orgânico total do solo durante as etapas de aplicação e incorporação do bioerbicida em estudo em comparação ao vaso de referência.

Tabela 43 - Teores de carbono orgânico total do solo ao longo do experimento com a planta Sida spinosa.

\begin{tabular}{lll}
\hline $\begin{array}{l}\text { Coletas } \\
(\text { dias })\end{array}$ & $\begin{array}{l}\text { Carbono orgânico } \\
\left(\mathrm{g} \mathrm{kg}^{-1}\right)\end{array}$ & $\begin{array}{l}\text { Carbono orgânico* } \\
\left(\mathrm{g} \mathrm{kg}^{-1}\right)\end{array}$ \\
\hline DAA15 & $6,16 \pm 0,61 \mathbf{a}$ & $6,36 \pm 0,02 \mathbf{a}$ \\
DAA30 & $6,09 \pm 0,06 \mathbf{a}$ & $5,61 \pm 0,06 \mathbf{b}$ \\
DAA45 & $6,00 \pm 0,28 \mathbf{a}$ & $5,42 \pm 0,13 \mathbf{b}$ \\
DAA60 & $6,03 \pm 0,50 \mathbf{a}$ & $5,53 \pm 0,07 \mathbf{a}$
\end{tabular}

*Vaso de referência. Médias seguidas pela mesma letra na linha não diferem significativamente entre si pelo teste de Tukey $(P<0,05)$. $(\mathrm{n}=3)$.

Não se pode considerar que o contato dos extratos tenha ação direta na variação dos teores de carbono no solo, logo, qualquer variação nos teores de carbono pode ser atribuída às condições ambientais (vento, clima, localização etc) em que o experimento foi realizado. 
Os testes de Shapiro-Wilk foram novamente realizados com base no que já foi discutido na página 138 (Tabela 32). A Tabela 44 apresenta os dados da distribuição normal da análise do solo referente ao uso do bioerbicida a planta invasora Sida spinosa.

Tabela 44 - Distribuição normal dos dados obtidos da análise do solo referente ao uso do bioerbicida na planta invasora Sida spinosa.

\begin{tabular}{lccc}
\hline & Graus de liberdade & Estatística: Shapiro- & P-valor* \\
& & Wilk (W) & \\
\hline $\mathrm{pH}($ água) & 12 & 0,86364 & 0,0543 \\
$\mathrm{pH}\left(\mathrm{CaCl}_{2}\right)$ & 12 & 0,81031 & 0,0123 \\
$\mathrm{H}+\mathrm{Al}$ & 12 & 0,58532 & $8,11355 \mathrm{E}-5$ \\
$\mathrm{P}_{\text {disp }}$ & 12 & 0,97260 & 0,93602 \\
Potássio & 12 & 0,89369 & 0,13148 \\
Cálcio & 12 & 0,86899 & 0,06329 \\
Nitrogênio & 12 & 0,91837 & 0,27266 \\
CTC & 12 & 0,85848 & 0,04680 \\
Carbono orgânico & 12 & 0,95312 & 0,68295
\end{tabular}
$*(\mathrm{P}<0,05)$.

Pela regra de decisão do teste de Shapiro-Wilk, tendo como exemplo os dados de $\mathrm{pH}$ $\left(\mathrm{CaCl}_{2}\right)$, temos $\mathrm{W}_{\text {calculado }}=0,81364<0,859_{(0,05,12)}$, com o valor de $\mathrm{P}$ calculado $=0,0123<0,05$. Assim, podemos afirmar com o nível de 5\% que a amostra não provém de uma população normal, devido a baixa aleatoriedade dos dados, o que não impede o cálculo da ANOVA, como já discutido.

Na Tabela 45 estão dispostos os resultados da caracterização do solo após aplicação e incorporação do bioerbicida, por meio da análise de variância (ANOVA). 
Tabela 45 - Resultados da análise do solo após aplicação e incorporação do bioerbicida no solo com a planta Sida spinosa.

\begin{tabular}{cccccccccc}
\hline $\begin{array}{c}\text { Tempo } \\
\text { de } \\
\text { coleta }\end{array}$ & $\begin{array}{c}\mathrm{pH} \\
\left(\mathrm{H}_{2} \mathrm{O}\right)\end{array}$ & $\begin{array}{c}\mathrm{pH} \\
\left(\mathrm{CaCl}_{2}\right)\end{array}$ & $\mathrm{H}+\mathrm{Al}$ & $\mathrm{P}$ disp & $\mathrm{K}$ & $\mathrm{Ca}$ & $\mathrm{N} \mathrm{Total}$ & $\begin{array}{c}\mathrm{CTC} \\
\text { Total }\end{array}$ & $\mathrm{CO}$ \\
\hline Dias* & & & & & & & & \\
DAA15 & $5,86 \mathbf{a}$ & $5,20 \mathbf{a}$ & $0,09 \mathbf{a}$ & $0,24 \mathbf{a}$ & $2,90 \mathbf{a}$ & $17,32 \mathbf{a}$ & $825,6 \mathbf{a}$ & $31,06 \mathbf{a}$ & $6,16 \mathbf{a}$ \\
DAA30 & $5,80 \mathbf{a b}$ & $5,04 \mathbf{a}$ & $0,12 \mathbf{b}$ & $0,23 \mathbf{a}$ & $3,00 \mathbf{a}$ & $17,24 \mathbf{a}$ & $466,3 \mathbf{b}$ & $49,03 \mathbf{b}$ & $6,01 \mathbf{a}$ \\
DAA45 & $5,53 \mathbf{a b}$ & $5,18 \mathbf{a}$ & $0,98 \mathbf{c}$ & $0,20 \mathbf{a}$ & $3,06 \mathbf{a}$ & $15,95 \mathbf{a}$ & $924,3 \mathbf{c}$ & $45,69 \mathbf{b}$ & $6,00 \mathbf{a}$ \\
DAA60 & $5,32 \mathbf{b}$ & $5,06 \mathbf{a}$ & $0,08 \mathbf{d}$ & $0,19 \mathbf{a}$ & $2,30 \mathbf{b}$ & $22,60 \mathbf{b}$ & $1184,3 \mathbf{d}$ & $52,36 \mathbf{b}$ & $6,03 \mathbf{a}$ \\
\hline
\end{tabular}

H+Al (acidez trocável), CTC (capacidade de troca catiônica), MO (matéria orgânica), CO (carbono orgânico). *Intervalo de coleta e análise do solo após aplicação do bioerbicida. Médias seguidas pela mesma letra na coluna não diferem significativamente entre si pelo teste de Tukey $(P<0,05)$. 
Quanto à análise de variância dos dados ao longo do experimento, podemos dizer que os valores de $\mathrm{pH}$, não apresentaram diferença significativa, de acordo com a Tabela 45, os valores de $\mathrm{pH}$ ao longo do experimento não foram significativamente diferentes, o que podemos deduzir que 4 aplicações sucessivas e cumulativas não alteraram o pH do solo

Os níveis de carbono e matéria orgânica não foram estatisticamente diferentes, ou seja, que a absorção deste nutriente pelas plantas de soja, provavelmente, não foi ideal. Os teores de fósforo, cálcio e potássio, em geral, não apresentaram diferenças estatísticas ao longo das aplicações dos extratos. A CTC foi afetada pelo contato dos extratos no solo, é possível notar que há um aumento no teor da CTC no intervalo entre DAA15 e DAA30 e uma igualdade estatística do DAA30 até o fim do experimento (DAA60), logo, não apresentando uma tendência a diminuir o teor de CTC após um total de 5 aplicações. Novamente, apenas o N apresentou variação estatística.

\subsection{Avaliação dos efeitos do bioerbicida na inibição do desenvolvimento da guanxuma (Sida spinosa)}

O experimento foi desenvolvido até o máximo de 60 dias. A principal característica observada durante o experimento foi a diferença no desenvolvimento da invasora guanxuma, que não alcançou um grande porte em comparação às plantas do vaso referência. Vale ressaltar que o desenvolvimento da soja não foi afetado, já que não foi submetida a aplicação direta dos extratos.

Baseados nos experimentos anteriores, utilizou-se o tratamento na concentração de $200 \mathrm{~g}$ $\mathrm{L}^{-1}$. Na Tabela 46 estão dispostos os conceitos das avaliações visuais para a planta invasora em estudo.

Tabela 46 - Resultado das avaliações visuais dos tratamentos sobre a Sida spinosa, de acordo com a escala de conceitos da SBCPD.

\begin{tabular}{ccccccc}
\hline Tratamento & $\begin{array}{c}\text { Dose por } \\
\text { planta }\end{array}$ & Modo de aplicação & \multicolumn{3}{c}{ Períodos de avaliação (dias) } \\
\hline $\mathrm{g} \mathrm{L}^{-1}$ & $\mathrm{~mL}$ & & 15 & 30 & 45 & 60 \\
200 & 3,0 & Dose única & $\mathrm{a}$ & $\mathrm{d}$ & $\mathrm{d}$ & $\mathrm{e}$ \\
\hline
\end{tabular}

(a)Sem injúria; (c) injúria moderada; (d) injúria severa; (e) destruição. 
A aplicação do bioerbicida no tempo zero foi definida com base no número de folhas e no porte alcançado pela planta invasora (31 dias após germinação das sementes). Avaliando-se as injúrias causadas após a aplicação do bioerbicida, observou-se que os extratos apresentaram efeito no $16^{\circ}$ dia, ou seja, após a $2^{\text {a }}$ aplicação dos extratos, onde, as folhas da planta apresentaram inicialmente uma coloração avermelhada que iniciada nas extremidades das folhas, distribuídas em toda área da folha (Figura 57).

Figura 57 - Estágio inicial de injúria na planta invasora Sida spinosa.

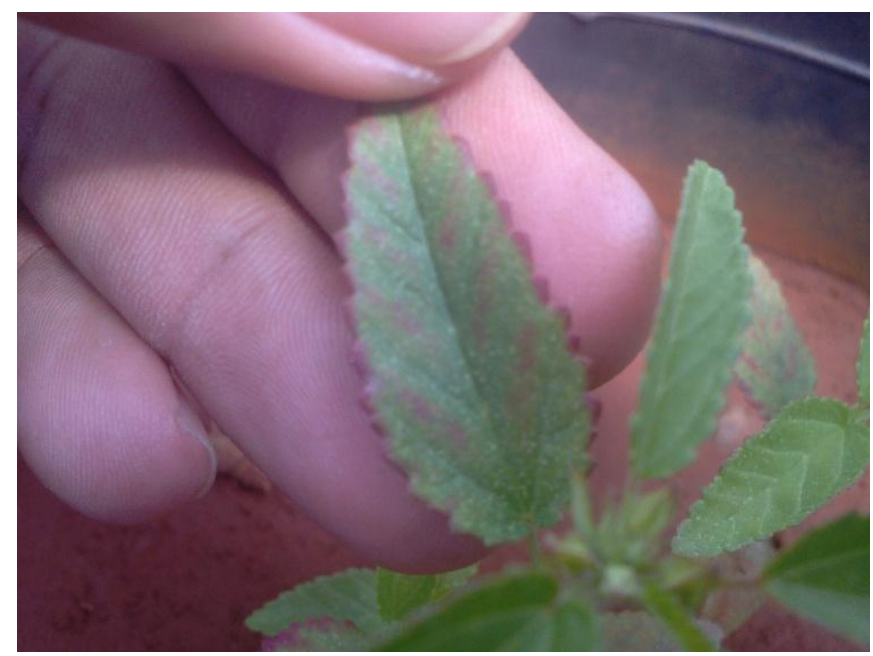

A Figura 58 apresenta as etapas de avaliação da ação do bioerbicida na planta invasora Sida spinosa.

Figura 58 - Etapas da avaliação do bioerbicida na planta invasora Sida spinosa. (a) sem aplicação do bioerbicida; (b)16 dias após aplicação; (c) 30 dias após aplicação. As fotos b e c estão ampliadas para melhor visualização das injúrias.
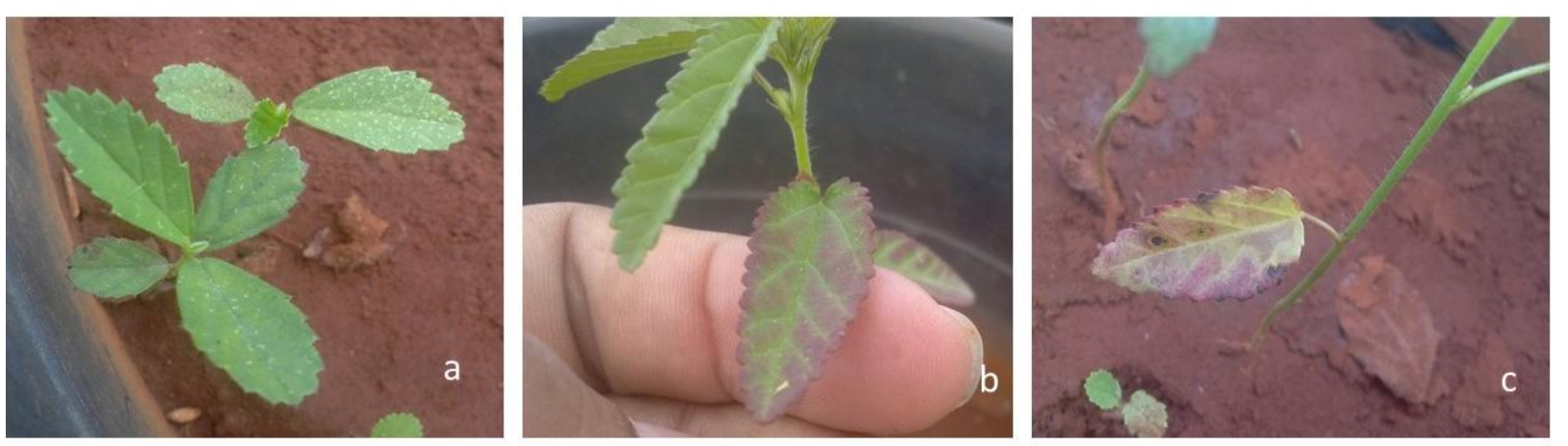

Com o início do tratamento, observou-se uma leve clorose nas folhas da planta, nas plantas menores, este efeito foi mais acentuado. 
O bioerbicida aplicado causa vulnerabilidade na superfície de contato, causando injúria foliar, que posteriormente poderá acarretar um processo de apoptose na planta. Como pode ser visto na Figura 58b, em plantas menores, a injúria causada pela ação dos extratos é maior, toda a área da folha torna-se avermelhada, posteriormente tornando-se amarelada, onde se inicia o processo de apoptose, acometendo toda a estrutura da planta, seguida das etapas de queda das folhas e finalmente a morte da planta. Em plantas mais desenvolvidas, a ação dos extratos causa injúria foliar caracterizada pela coloração vermelha das folhas, mas, não impedindo o desenvolvimento da planta (Figura 59), retardando, o processo apoptótico. Para continuar ou acelerar processo de apoptose, um número maior de aplicações se faz necessário.

Figura 59 - Planta invasora Sida spinosa 50 dias após aplicação do bioerbicida.

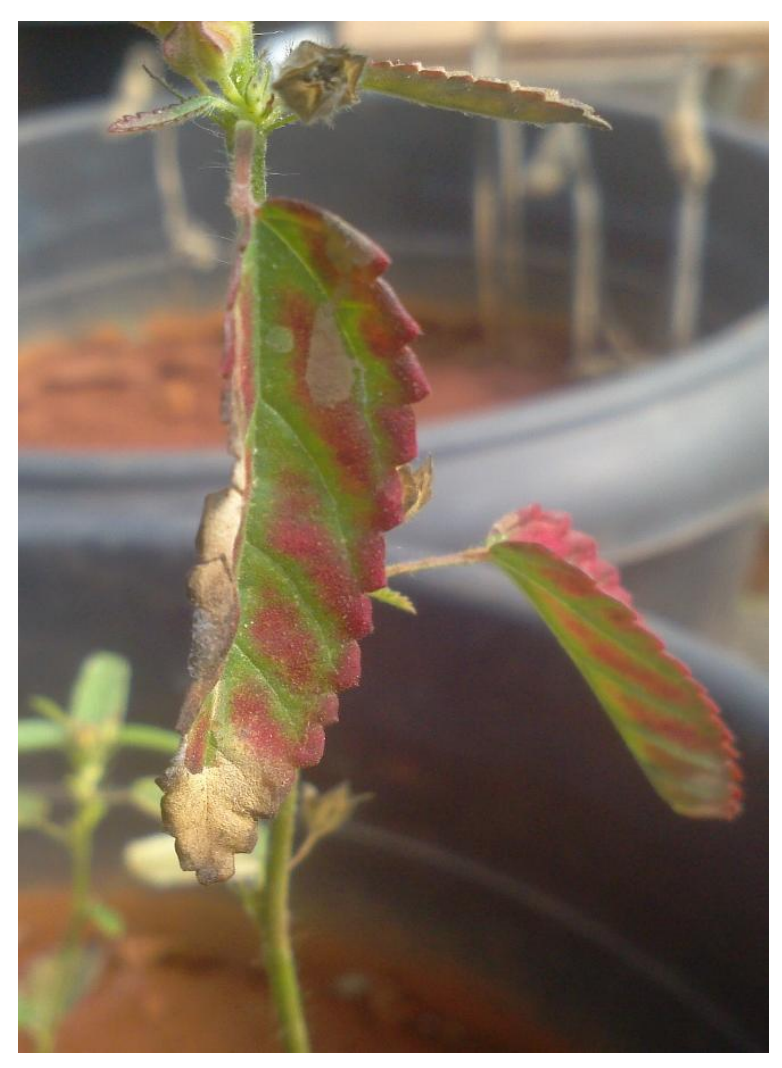

No $50^{\circ}$ dia do experimento as plantas mais desenvolvidas da Sida spinosa já apresentavam características de injúrias mais severas. Como pode ser visto na Figura 59 a coloração vermelha já se estende em grande parte da folha, a planta já está murcha e o início da morte do tecido vegetal na extremidade da folha já é visível. Assim, a aplicação tardia do bioerbicida implica em um controle deficiente e/ou a longo prazo. A Figura 60 apresenta a invasora Sida spinosa na última etapa do experimento (60 dias), sem a ação do bioerbicida. 
Figura 60 - Planta invasora Sida spinosa sem a ação do bioerbicida.

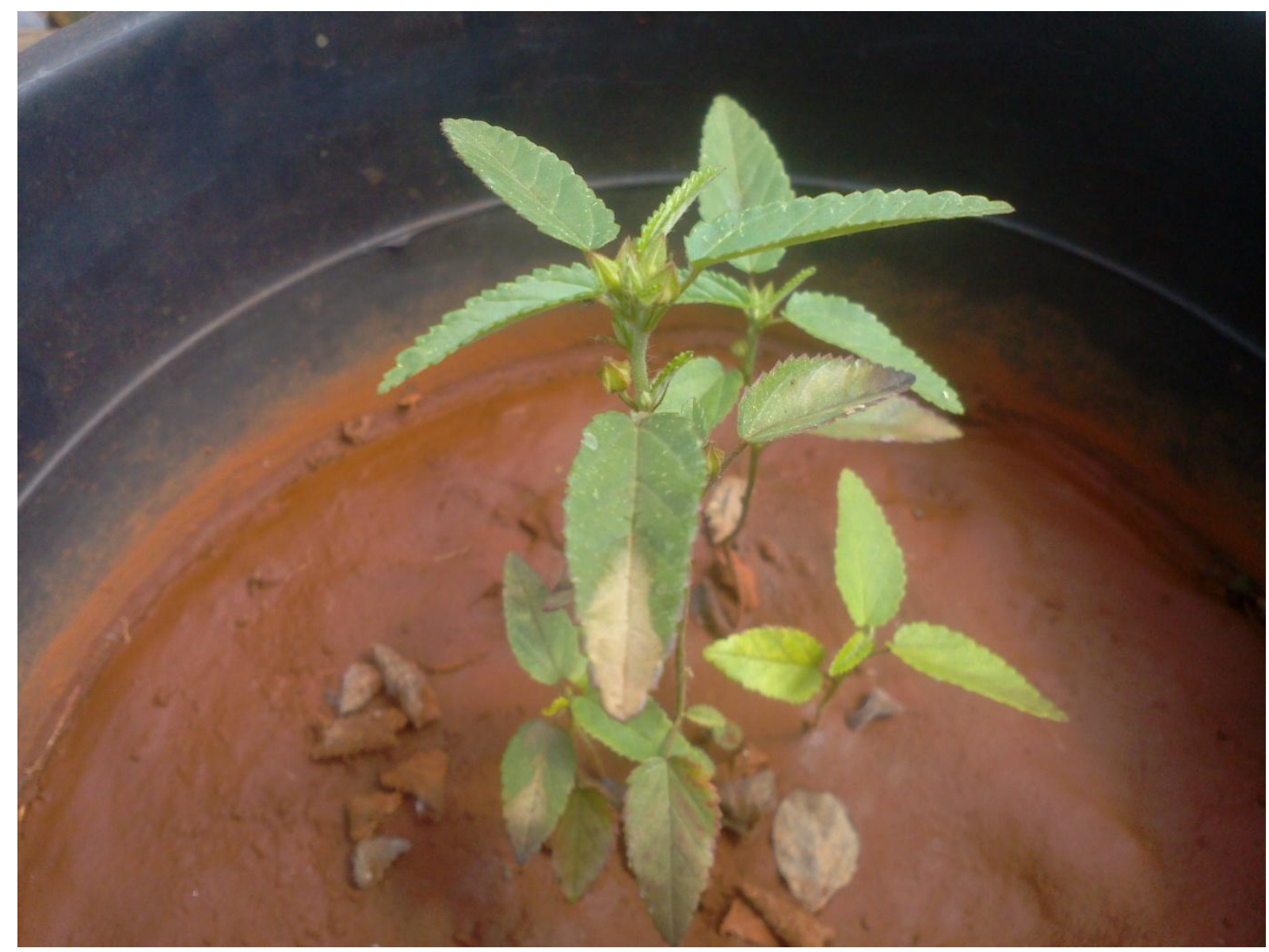

As plantas da guanxuma atingiram aproximadamente $21 \mathrm{~cm}$ de altura, suas folhas atingiram aproximadamente $7 \mathrm{~cm}$. Em comparação às plantas que foram sujeitas ao tratamento, pode-se afirmar que a ação dos extratos inibiu o crescimento desta invasora. A Tabela 47 apresenta as medidas das plantas e suas folhas durante as etapas de avaliação do experimento. 
Tabela 47 - Análise de variância (ANOVA) da altura e comprimento das folhas da planta invasora (Sida spinosa) sob aplicação do bioerbicida e no vaso referência.

\begin{tabular}{crrrr}
\hline $\begin{array}{c}\text { Período de } \\
\text { avaliação } \\
\text { (dias) }\end{array}$ & \multicolumn{2}{c}{$\begin{array}{c}\text { Altura da planta } \\
(\mathrm{cm})^{*}\end{array}$} & \multicolumn{2}{c}{$\begin{array}{c}\text { Comprimento das folhas } \\
(\mathrm{cm})^{*}\end{array}$} \\
& $\begin{array}{c}\text { Sob aplicação } \\
\text { do bioerbicida }\end{array}$ & Vaso referência & $\begin{array}{c}\text { Sob aplicação } \\
\text { do bioerbicida }\end{array}$ & Vaso referência \\
\hline DAA15 & $1,88 \pm 0,21 \mathbf{a}$ & $2,48 \pm 0,37 \mathbf{b}$ & $2,10 \pm 0,38 \mathbf{a}$ & $2,28 \pm 0,25 \mathbf{a}$ \\
DAA30 & $4,38 \pm 0,25 \mathbf{a}$ & $6,68 \pm 0,39 \mathbf{b}$ & $3,48 \pm 0,74 \mathbf{a}$ & $5,00 \pm 0,18 \mathbf{b}$ \\
DAA45 & $7,18 \pm 0,14 \mathbf{a}$ & $15,54 \pm 0,37 \mathbf{~ b}$ & $4,42 \pm 0,37 \mathbf{a}$ & $6,18 \pm 0,17 \mathbf{b}$ \\
DAA60 & $10,10 \pm 0,55 \mathbf{a}$ & $21,56 \pm 0,82 \mathbf{b}$ & $4,86 \pm 0,50 \mathbf{a}$ & $6,98 \pm 0,29 \mathbf{b}$
\end{tabular}

*Médias de 5 plantas. Médias seguidas pela mesma letra na linha não diferem significativamente entre si pelo teste de Tukey $(P<0,05)$.

As plantas invasoras sujeitas à ação do bioerbicida chegaram a uma altura máxima de aproximadamente $10 \mathrm{~cm}$. A planta invasora presente no vaso de referência conseguiu atingir aproximadamente $21 \mathrm{~cm}$, conforme mostrado na Tabela 47.

As plantas do vaso referência apresentaram um melhor desenvolvimento quanto à biometria. A medida do comprimento das folhas das plantas invasoras presente no vaso referência também se desenvolveu melhor, conseguindo atingir aproximadamente $7 \mathrm{~cm}$ em relação às medidas das plantas sob ação dos extratos, que alcançaram aproximadamente $5 \mathrm{~cm}$.

Estatisticamente as medidas das plantas do vaso referência foram diferentes das dos vasos sob aplicação do bioerbicida. A invasora Sida spinosa atingiu um tamanho próximo ao da soja $(20 \mathrm{~cm})$, apresentando o dobro do tamanho daquelas sujeitas às aplicações dos extratos. Quanto à biometria das folhas, foi verificado que apesar da injúria causada inicialmente, o desenvolvimento da planta só foi prejudicado após uma segunda aplicação do bioerbicida. A Figura 61 mostra o desenvolvimento da planta invasora ao longo do experimento 
Figura 61 - Desenvolvimento da planta invasora Sida spinosa.

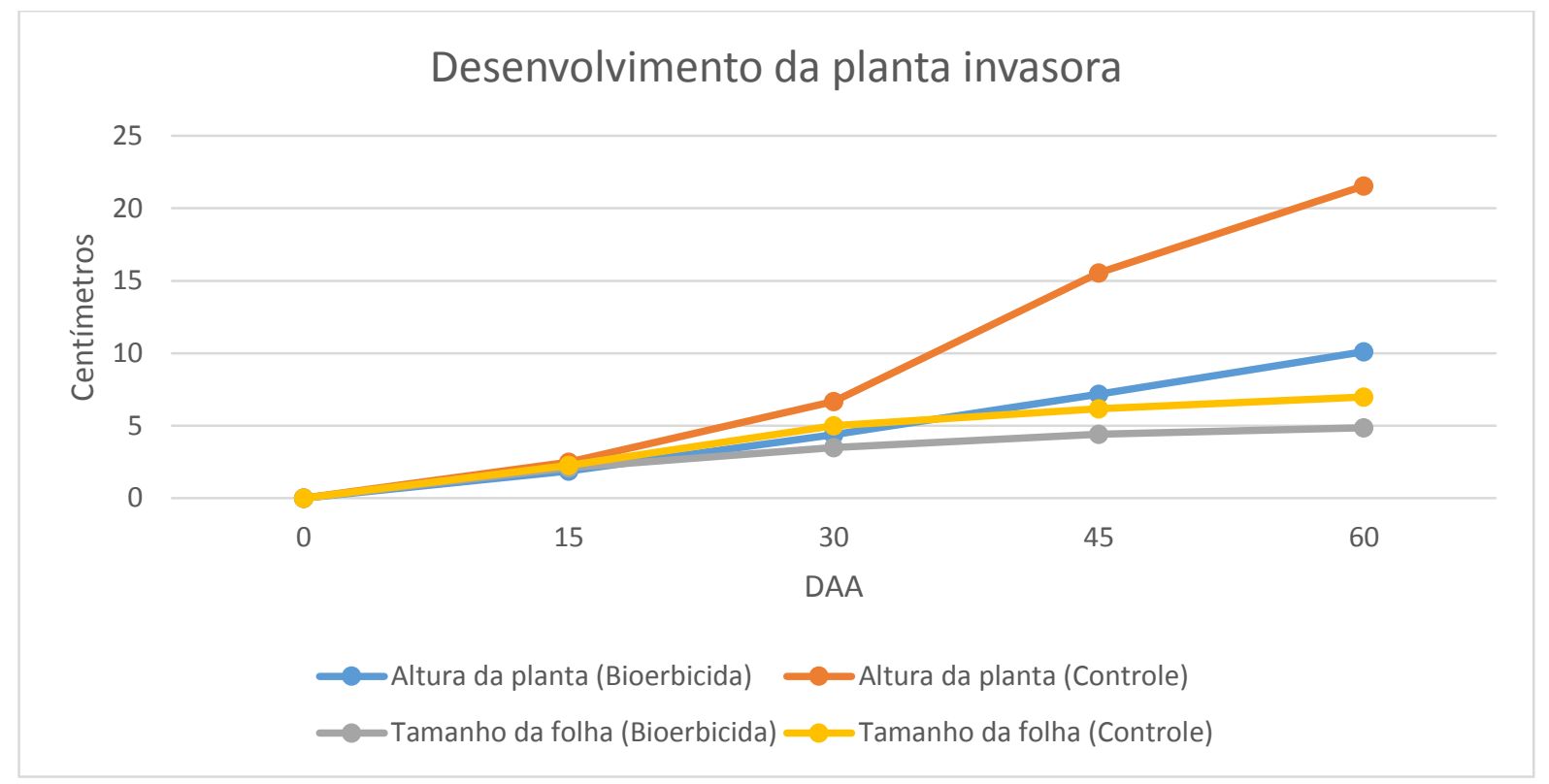

Das medidas do comprimento das folhas, a análise estatística foi semelhante às do experimento com a Emilia sonchifolia, ou seja, o desenvolvimento foi afetado a partir da segunda aplicação do bioerbicida, consequentemente após os primeiros sinais de injúrias causados pela ação dos extratos. Na Tabela 48, estão os valores médios de controle da planta invasora.

Tabela 48 - Valores médios da porcentagem de controle da Sida spinosa tratadas com 3,0 mL dos extratos aquosos da Canavalia ensiformis na concentração de $200 \mathrm{~g} \mathrm{~L}^{-1}$.

\begin{tabular}{ccc}
\hline $\begin{array}{c}\text { Período de } \\
\text { avaliação } \\
\text { (dias) }\end{array}$ & $\begin{array}{c}\text { Média } \\
(\%)\end{array}$ & $\begin{array}{c}\text { Conceito de } \\
\text { ALAM } \\
(1974)\end{array}$ \\
\hline DAA15 & 0,00 & Nenhum \\
DAA30 & 50,00 & Suficiente \\
DAA45 & 85,00 & Muito bom \\
DAA60 & 90,00 & Muito bom \\
\hline
\end{tabular}

$\mathrm{Na}$ avaliação referente ao DAA15, o tratamento não proporcionou qualquer injúria visível, sendo que o primeiro sintoma de dano à planta foi observado um dia depois após a segunda aplicação dos extratos. Tendo como base o início das injúrias causadas na planta e os sinais de mal desenvolvimento da planta, confirmadas pela biometria, aos DAA30, consideramos a ação dos extratos suficiente quanto ao controle da planta invasora. Nos dias 
seguintes de avaliação (DAA45 até o DAA60) o conceito de controle foi considerado muito bom, já que os dados da biometria indicaram a inibição do desenvolvimento da planta invasora e principalmente pelos sinais de fitotoxicidade na planta já estavam em um estágio bem avançado. Logo, o tratamento testado mostrou uma porcentagem de controle efetivo (90\%) no período final do experimento e controle muito bom, já que foi possível matar todas as plantas invasoras do sistema.

Depois de liberados no ambiente por meio de diversas rotas, os aleloquímicos podem causar efeitos diretos e indiretos sobre as plantas. Os efeitos indiretos constituem qualquer alteração nas características nutricionais do solo, como também, nas populações, atividades de micro-organismos e insetos. Os efeitos diretos compreendem as alterações no crescimento e metabolismo vegetal, englobando alterações em nível celular, fitormonal, fotossintético e respiratório, consequentemente, dificultando a absorção de nutrientes e água, entre outros (MARASHIN-SILVA; AQUILA, 2006).

Numa análise geral do nosso experimento, a ação dos extratos aquosos como potencial bioerbicida no combate de plantas invasoras na cultura de soja convencional foi satisfatória, considerando-se que ao longo do experimento o contato dos extratos aquosos não causou efeito deletério na composição do solo.

O desenvolvimento da soja não foi afetado pela ação dos extratos que atingiram o solo, sendo que apenas as plantas invasoras foram sujeitas à aplicação direta dos extratos. Avaliandose os níveis de nitrogênio no solo e as características do desenvolvimento da soja foi observado um ciclo dessa cultura, ou seja, morte da planta, liberação de novas sementes no solo e nova germinação.

Em geral, as principais alterações nas características do solo estão relacionadas à CTC e à acidez trocável. A CTC do solo em todos os experimentos apresentou variações ao longo das determinações, não mostrando uma tendência direta com as sucessivas aplicações dos extratos nas plantas invasoras. Quanto à acidez do alumínio, em geral, as aplicações cumulativas dos extratos não aumentaram a toxicidade no solo, considerando-se a baixa persistência do bioerbicida no solo. Dos demais elementos analisados, pôde-se inferir que as variações nos teores destes são resultado da dinâmica das plantas no sistema relacionadas à absorção de nutrientes pelas plantas.

Os principais problemas da utilização de agrotóxicos são a contaminação de águas usadas na irrigação, que assim poluem o solo e, consequentemente, o lenço freático. Assim, os aleloquimicos extraídos de plantas têm menor persistência no solo e, de acordo com o presente 
trabalho, são possivelmente menos tóxicos ao ambiente, considerando-se o tempo de meia vida dos compostos fenólicos que é menor comparado aos dos compostos obtidos sinteticamente.

A agricultura orgânica é um processo produtivo comprometido com a organicidade e sanidade da produção de alimentos para garantir a saúde dos seres humanos, é um modo de produção segura, que tem como objetivo fornecer alimentos saudáveis, mais saborosos e de maior durabilidade. A prática da agricultura orgânica implica também no uso de adubos orgânicos como o uso da compostagem da matéria orgânica; minhocultura, gerador de húmus com diferentes graus de fertilidade; rotação de culturas e o uso racional de águas de irrigação.

Logo, o processo de produção orgânica está ligado aos princípios agroecológicos que contemplam o uso responsável do solo, da água, do ar e dos demais recursos naturais, respeitando as relações sociais e culturais. O cultivo do feijão-de-porco promove a fertilidade do solo graças à sua capacidade de fixar nitrogênio e os bioerbicida dele extraídos são substitutos dos herbicidas sintéticos tão indiscriminadamente utilizados no Brasil. 


\section{CONCLUSÕES}

O objetivo geral deste trabalho foi avaliar o potencial bioerbicida dos extratos aquosos obtidos das folhas de feijão-de-porco (Canavalia ensiformis) via extração assistida por microondas nas plantas invasoras Emilia sonchifolia e Sida spinosa, avaliando também a seletividade dos extratos no cultivo de soja convencional. Como parte dos objetivos, o bioerbicida foi preparado e aplicado nas plantas invasoras em estudo, onde quinzenalmente foram realizadas as avaliações visuais e a biometria quanto às injúrias causadas nas plantas e paralelamente a análise do solo, como forma de avaliar os efeitos provocados com a utilização desses extratos após sucessivas aplicações.

O bioerbicida extraído das folhas do feijão-de-porco tem capacidade herbicida contra as plantas invasoras Emilia sonchifolia e Sida spinosa. O herbicida não é seletivo, portanto, seu uso deve ser feito em caráter pós-emergente, diretamente na planta invasora que se quer combater. Sucessivas aplicações do bioerbicida (totalizando 5 aplicações) na planta invasora, com a sua subsequente disponibilidade no solo, não afetaram drasticamente as características do solo, nos intervalos de tempo avaliados, entretanto, quanto menor a superfície de contato (tamanho da folha) maior a possibilidade dos extratos atingirem o solo, devido a uma maior dispersão do bioerbicida. Os primeiros sintomas foram notados 24 h após a primeira aplicação na Emilia sonchfolia e após 16 dias para a Sida spinosa.

Em geral, a acidez do solo não apresentou diferenças significativas ao longo dos experimentos com as plantas invasoras, não acarretando quaisquer prejuízos ao desenvolvimento das plantas de soja no sistema. As variações dos níveis de nutrientes no solo associadas à boa correlação dos níveis de matéria orgânica e à capacidade troca catiônica favoreceram a disponibilidade de nutrientes em todas as etapas do processo, não afetando as características de fertilidade do solo e, consequentemente, promovendo o desenvolvimento da cultura de interesse e das plantas invasoras no vaso referência. Da diferença estatística dos teores de fósforo, cálcio, potássio e pH, não se pôde identificar nenhuma tendência à diminuição ou aumento desses teores relacionados à incorporação dos extratos no solo.

O método desenvolvido para análise cromatográfica dos compostos fenólicos: ácido clorogênico, rutina, naringenina e ácido ferúlico foi adequado considerando-se as porcentagens de recuperações e desvios padrão numa faixa analiticamente aceitável.

Quanto à extração assistida por micro-ondas, a temperatura foi o principal parâmetro a afetar o processo, considerando-se a temperatura máxima utilizada de $100^{\circ} \mathrm{C}$ e o uso de água como solvente extrator. As superfícies de resposta foram adequadas para estimar o efeito das 
três variáveis independentes (temperatura, tempo e rampa). Os dados experimentais mostraram que os termos lineares e suas interações tiveram efeito significativo sobre a resposta obtida.

Os sintomas de injúria causados pela ação dos extratos foram distintos em relação ao tamanho da planta invasora. A invasora Emilia sonchifolia, aparentemente bem desenvolvida no momento da $1^{\mathrm{a}}$ aplicação, apresentou os primeiros sinais de injúria em um tempo menor em relação à Sida Spinosa que tinha um porte notavelmente menor. Outro fato interessante foi o tempo de controle menor da Sida spinosa (60 dias) em relação ao tempo de controle da Emilia sonchifolia (75 dias), onde pode-se inferir que o tamanho da planta tem relação direta com o tempo de controle, ou seja, quanto mais desenvolvida a planta estiver, menor será o efeito do bioerbicida e, consequentemente, maior será o tempo de controle da invasora. Em relação às injúrias, pode-se dizer que a invasora Sida spinosa mostrou-se mais resistente à ação do bioerbicida, em outras palavras, o processo de morte celular (apoptose) necessitou de um tempo maior para se tornar evidente (visível na planta), onde, pelas características apresentadas em cada invasora, pode-se dizer que o processo apoptótico é diferente de uma espécie para outra.

Quanto à seletividade do bioerbicida, considera-se adequada a aplicação direta apenas nas plantas invasoras, já que os primeiros testes na plantação de soja apresentaram injúrias com o uso da menor concentração dos extratos $\left(100 \mathrm{~g} \mathrm{~L}^{-1}\right)$, o que consequentemente prejudicou o desenvolvimento normal da cultura. No entanto, interrompendo-se a aplicação direta, a soja desenvolveu-se adequadamente, isto é, tanto o contato nas plantas de soja quanto a incorporação do extrato bioerbicida ao solo não afetaram a recuperação da soja. Assim, o bioerbicida obtido das folhas da Canavalia ensiformis tem seu modo de aplicação semelhante aos herbicidas sintéticos comercializados utilizadas para o controle de invasoras em pós-emergência. 


\section{CONSIDERAÇÕES FINAIS}

Considerando-se os parâmetros de otimização da metodologia de extração do bioerbicida, é possível fazer adaptações para que o pequeno agricultor realize o preparo do bioerbicida e o utilize em um sistema de produção orgânica.

Aplicações repetidas do mesmo princípio ativo numa mesma área podem selecionar uma microbiota específica. Micro-organismos utilizam compostos fenólicos como fonte de alimento para crescimento, assim como para o aumento de sua população através da rápida decomposição destes compostos. Nossa sugestão é que o bioerbicida seja utilizado dentro dos mesmos períodos avaliados durante o trabalho, ou seja, quinzenalmente, de forma a evitar qualquer possível ação adaptativa da microbiota.

Assim como muitos dos herbicidas não seletivos e de aplicação em pós-emergência disponíveis comercialmente, os extratos aquosos da Canavalia ensiformis com potencial bioerbicida poderiam ser utilizados da mesma forma, ou seja, utilizando-se doses de acordo com o estágio de desenvolvimento da planta invasora, doses menores para plantas no estágio inicial da atividade vegetativa e doses maiores para plantas perenizadas, sendo aplicados de forma direcionada via pulverização.

Considerando-se que o uso de fertilizantes e pesticidas sintéticos caracterizam uma prática proibida em agricultura orgânica, o uso da leguminosa feijão-de-porco seria uma forma de adubação verde, considerando-se as características do feijão-de-porco, como a boa adaptação, a tolerância a solos ácidos e às adversidades ambientais e principalmente a fixação de nitrogênio atmosférico. Logo, o cultivo do feijão-de-porco associado ao cultivo da soja, aumentaria a fertilidade do solo e promoveria a produção das folhas do feijão-de-porco para posterior obtenção dos extratos com capacidade bioerbicida. 


\section{Darlan Ferreira da Silva}

Graduado: Licenciatura em química pela Universidade Estadual do Maranhão - UEMA (2008)

Mestrado em Química Analítica pela Universidade Federal do Maranhão - UFMA (2010)

Doutorando pelo Instituto de Química da Universidade de São Paulo - IQSC-USP (2012-2016)

Publicações:

1. SILVA, D. F.; LANDGRAF, M. D. ; REZENDE, M. O. O. An expeditious method for determination of polychlorinated biphenyls in liquid humus using optimized microwaveassisted extraction methodology followed by gas chromatograph-mass spectrometry. American Open Chemistry Journal, v. 2, p. 1-13, 2016.

2. SILVA, D. F.; AZEVEDO, E. B. ; REZENDE, M. O. O. Optimization of MicrowaveAssisted Extraction of a Bioherbicide from Canavalia ensiformis Leaves. American Journal of Environmental Sciences, v. 12, p. 27-32, 2016.

3. SILVA, D. F.; LANDGRAF, M. D. ; REZENDE, M. O. O. Optimization of a microwaveassisted extraction method for the analysis of the persistent organic pollutant $\mathrm{p}, \mathrm{p}$ ?-DDT in domestic sewage sludge. American Open Chemistry Journal, v. 2, p. 14-26, 2016.

4. SILVA, DARLAN FERREIRA; LANDGRAF, MARIA DIVA ; REZENDE, MARIA OLIMPIA . Fast and Sustainable Determination of Persistent Organic Pollutants from Organic Fertilizer Using Optimized Microwave-Assisted Extraction Method and Gas Chromatography-Mass Spectrometry. OALib, v. 02, p. 1-8, 2015.

5. SILVA, D. F.; SILVA, F. E. P. S. S. ; SILVA, F. G. S. ; NUNES, G. S. ; BADEA, M. . Direct determination of methyl parathion insecticide in rice samples by headspace solid-phase microextraction-gas chromatography-mass spectrometry. Pest Management Science, v. 71, p. 1497-1502, 2014. 


\section{REFERÊNCIAS}

ABBOTT, M. P. Modificações oxidativas e proteínas em presença de complexos de cobre (II). 2007. 138 f. Tese (Doutorado) - Instituto de Química, Universidade de São Paulo, São Carlos, 2007.

AGÊNCIA NACIONAL DE VIGILÂNCIA SANITÁRIA (ANVISA). Guia para validação de métodos analíticos e bioanalíticos, Brasília, 2003.15 p.

AGÊNCIA NACIONAL DE VIGILÂNCIA SANITÁRIA (ANVISA). Seminário de mercado de agrotóxico e regulação. Brasília, 2012.

AGRA, M. F.; FREITAS, P. F.; BARBOSA-FILHO, J. M. Synopsis of the plants knows as medicinal and poisonous in Northeast of Brazil. Brazilian Journal Pharmacognosy, v. 17, p.114-140, 2007.

AGROLINK. Fertilizantes. 2016. Disponível em:

<http://www.agrolink.com.br/fertilizantes/nutrientes_fosforo.aspx>. Acesso em: 24 fev. 2016.

ALMEIDA, E. L.; MARCOS, F. C. C.; SCHIAVINATO, M. A.; LAGÔA, A. M. M. A.; ABREU, M. F. Crescimento de feijão-de-porco na presença de chumbo. Bragantia, v. 67, p. 569-576, 2008.

ANDRADE, S. A. L.; GRATÃO, P. L.; AZEVEDO, R. A.; SILVEIRA, A. P. D.; SCHIAVINATO, M. A.; MAZZAFERA, P. Biochemical and physiological changes in Jack bean under mycorrhizal symbiosis growing in soil with increasing $\mathrm{Cu}$ concentrations.

Environmental and Experimental Botany, v. 68, p. 198-207, 2010.

ARAKAWA, S.; NAKANOMYO, I.; KUDO-SAKAMOTO, Y.; AKAZAWA, H.; KOMURO, I.; SHIMIZU, S. Identification of a novel compound that inhibits both mitochondria-mediated necrosis and apoptosis. Biochemical and Biophysical Research Communications, v. 467, p. 1006-1011, 2015.

ARMENTA, S.; GARRIGUES, S.; DE LA GUARDIA, M. Green analytical chemistry. Trends in Analytical Chemistry, v. 27, 6, p. 497-511, 2008.

ARRUDA, M. A. Z.; SANTELLI, R. E. Mecanização no preparo de amostras por microondas: o estado da arte. Química Nova, v. 20, n. 6, p. 638-643, 1997. 
ARTURKI, A.; FANALI, S.; D’ ORAZIO, G.; ROCCO, A.; ROSATI. C. Analysis of phenolic compounds in extra virgin oil by using reversed-phase capillary electrochromatography. Electrophoresis, v. 29, p. 1643-1650, 2008.

ASKUN, T.; TUMEN, G.; SATIL, F., ATES, M. In vitro activity of methanol extracts of plants used as spices against Mycobacterium tuberculosis and other bacteria. Food Chemistry, v. 116, p. 289-294, 2009.

ASSOCIAÇÃO BRASILEIRA DE SAÚDE COLETIVA (ABRASCO). Dossiê ABRASCO: Um alerta sobre os impactos dos agrotóxicos na saúde. Rio de Janeiro, 2012. Parte 1 Agrotóxicos, Segurança Alimentar e Nutricional e Saúde.

ASSOCIAÇÃO DOS PRODUTORES DE SOJA DO BRASIL (APROSOJA). Uso da soja. 2014.Disponível em: <http://aprosojabrasil.com.br/2014/sobre-a-soja/uso-da-soja/>. Acesso em: 04 abr. 2016.

ASSOCIACIÓN LATINOAMERICANA DE MALEZAS (ALAM). Recomendaciones sobre unificación de los sistema de evaluación em ensayos de control de malezas. ALAM, v. 1, n. 1, p. 35-38, 1974.

ASSOCIAÇÃO BRASILEIRA DE NORMAS TÉCNICAS (ABNT). NBR: 7181: SoloAnálise granulométrica. Rio de Janeiro, 1984. 13 p.

ASSOCIAÇÃO BRASILEIRA DE NORMAS TÉCNICAS (ABNT). NBR: 6457: Amostras de solo - preparação para ensaios de compactação e ensaios de caracterização. Rio de Janeiro, 1986. 9 p.

BAILEY, K. L.; FALK, S.; DERBY, J-A.; MELZER, M.; BOLAND, G. J. The effect of fertilizer on the efficacy of the bioherbicide, Phoma macrostoma, to control dandelions in turfgrass. Biological Control, v. 65, p. 147-151, 2013.

BALLARD, T. S.; MALLIKARJUNAN, P.; ZHOU, K.; O’KEEFE, S. Microwave-assisted extraction of phenolic antioxidant compounds from peanuts skins. Food Chemistry, v. 120, p. 1185-1192, 2010.

BERNAL, J.; MENDIOLA, J.A.; IBÁÑ̂̂ZZ, E.; CIFUENTES, A. Advanced analysis of nutraceuticals. Journal of Pharmaceutical and Biomedical Analysis, v. 55, p. 758-774, 2010 .

CAIRES, E. F. Soil acidity, liming and soybean performance under no-till. Scientia Agrícola, v.65, n. 5, p. 532-540, 2008. 
CALLIHAN, B.; SMITH, L.; McCAFFREY, J.; MICHALSON, E. Yellow starthistie management for small acreages. Agricultural Experiment Station, CIS 1025, p. 8, 1995.

CAMEL, V. Microwave-assisted solvent extraction of environmental samples. Trends Analytical Chemistry, v.19, p. 229-248, 2000.

CARVALHO, L. B. Plantas daninhas. Lages: Bookman, 2013. 82 p.

CASAZZA, A. A.; ALIAKBARIAN, B.; MANTEGNA, S.; CRAVOTTO, G.; PEREGO, P. Extraction of phenolics from Vitis vinífera wastes using non-conventional techniques. Journal of Food Engineering, v. 100, p. 50-55, 2010.

CASPERSEN, S.; ALSANIUS, B. W.; SUNDIN, P.; JENSÉN, P. Bacterial amelioration of ferulic acid toxic to hydroponically grown lettuce (Lactuca sativa L.). Soil Biology $\boldsymbol{\&}$ Biochemistry, v. 32, p. 1063-1070, 2000.

CASTRO, O. M.; LOMBARDI NETO, F.; DE MARIA, I. C.; DECHEN, S. C. F. Evolução das perdas do solo e água em latossolo roxo cultivado com milho e soja sob diferentes sistemas de preparo. In: CONGRESSO BRASILEIRO DE CIÊNCIAS DO SOLO, 24., 1993, Goiânia. Programas e resumos...Goiás: Sociedade Brasileira de Ciência do Solo, 1993. p. 89-90.

CAVALHEIRO, M. C. H. T. Coletânea de riscos e normas de segurança em laboratório. São Carlos: IQSC, 2010. 140 p.

CHEN, H.; ZUO, Y.; DENG, Y. Separation and determination of flavonoids and other phenolics compounds in cranberry juice by high performance liquid chromatography. Journal of Chromatography A, v. 913, p. 387-395, 2001.

CHINNICI, F.; SPINABELLI, U.; RIPONI, C.; AMATI, A. Optimization of the determination of organic acids and sugars in fruit juices by ion-exclusion liquid chromatography. Journal of Food Composition and Analysis, v. 18, p. 121-130, 2005.

CHO, K. M.; HA, T. J.; LEE, Y. BOK.; SEO, W. D.; KIM, J. Y.; RYU, H. W.; JEONG, S. H.; KANG, Y. M.; LEE, J. H. Soluble phenolics and antioxidant properties of soybean (Glycine max L.) cultivars with varying seed coat colours. Journal of Functional Foods, v. 5, p. 1065-1076, 2013.

CIRALE, S.; LUCAS, L.; KEAST, R. Biological activities of phenolics compounds present in virgin olive oil. Internacional Journal of Molecular Science, v. 11, p. 458-479, 2010. 
CLARKE, P. G.; CLARKE, S. Historic apoptosis. Nature, v. 378, p. 230, 1995.

CLARKE, P. G. Developmental cell death: morphological diversity and multiple mechanisms. Anatycal Embryology, v. 181, p. 195-213, 1990.

COLLINS, C. H.; BRAGA, G. L. Introdução a métodos cromatográficos. 1a. ed. Campinas: Editora da Universidade de Campinas, 1987. 298 p.

COLLINS, C. H.; BRAGA, G. L.; BONATO, P. S. Fundamentos de cromatografia. Campinas: Editora da Unicamp, 2011. 453 p.

DARWISH, F. M.; REINECKE, M. G. Ecsdysteroids and others constituents from Sida spinosa L. Phtytochemistry, v. 62, p. 1179-1184, 2003.

DEPARTAMENTO DO AGRONEGÓCIO (DEAGRO). Safra Mundial de soja 2015/1610 $^{\circ}$ levantamento do USDA. Rio Grande do Sul, 2016. 4 p.

DEVOR, R. E.; CHANG, T.; SUTHERLAND, J. W. Statistical quality design and control - Contemporary concepts and methods. New York: Prentice Hall, 1992. p. 503-744.

DOBOR, J.; VARGA, M.; YAO, J.; CHEN, H.; PALKÓ, G.; ZARAY, G. A new sample preparation method for determination of acid drugs in sewage sludge applying microwave assisted solvent extraction followed by gas chromatography-mass spectrometry.

Microchemistry Journal, v. 94, p. 36-41, 2010.

DONG, Y. J.; BARTLAM, M.; SUN, L. ZHOU, Y.F.; ZHANG, Z.P.; ZHANG, C.G.; RAO, Z.; ZHANG, X.E. Crystal structure of methyl parathion hydrolase from Pseudomonas sp WBC-3. Journal of Molecular Biology, v. 353, p.655-663, 2005.

DOUBLET, J.; MAMY, L.; BARRIUSSO, E. Delayed degradation in soil o foliar herbicides glyphosate and sulcotrione previously absorbed by plants: Consequences on herbicides fate and risk assessment, Chemosphere, v. 77, p. 582-589, 2009.

EISENBERG-LERNER, A.; BIALIK, S.; SIMON, H.U.; KIMCHI, A. Life and death partners: apoptosis, autophagy and the cross-talk between them, Cellular Death \& Differency, v.16, p. 966-975, 2009.

EMPRESA BRASILEIRA DE PESQUISA AGROPECUÁRIA (EMBRAPA). Manual de métodos de análise de solo. $2^{a}$ edição. Rio de Janeiro. Embrapa- CNPS. 1997. 212 p. 
EMPRESA BRASILEIRA DE PESQUISA AGROPECUÁRIA (EMBRAPA). Tecnologias de produção de soja: Região Central do Brasil 2012 e 2013. Londrina. Embrapa Soja, 2011. $261 \mathrm{p}$.

EMPRESA BRASILEIRA DE PESQUISA AGROPECUÁRIA (EMBRAPA). Sistema brasileiro de classificação de solos. 2a edição, Brasília. Embrapa- SPI, 2006. 306 p.

ERASTO, P.; BOJASSE-MOLETA, G.; MAJINDA, R. R. Antimicrobial and antioxidant flavonoids from the root Wood of Bolusanthus speciosos. Phytochemistry, v. 65, p. 875-880, 2004.

ESKILSSON, C. S.; BJORKLUND, E. Analytical-scale microwave-assisted extraction. Journal of Chromatography A, v. 902, p. 227-250, 2000.

FERREIRA, E. G. B. S.; MATOS, V. P.; SENA, L. H. M.; SALES, A. G. F. A. Efeito alelopático do extrato aquoso de sabiá na germinação de sementes de fava. Revista Ciência Agronômica, v.41, n.3, p. 463-467, 2010.

FERROCHIO, L.; CENDOYA, E.; FARNOCHI, M.; MASSAD, W.; RAMIREZ, M. L. Evaluation of ability of ferulic acid to control growth and fumonisin production of Fusarium verticillioides and Fusarium proliferatum on maize based media. International Journal of Food Microbiology, v. 167, p. 215-220, 2013.

FILLY, A.; FERNANDEZ, X.; MINUTI, M.; VISINONI, F.; CRAVOTO, G.; FARID, C. Solvent-free microwave extraction of essential oil from aromatic herbs: From laboratory to pilot and industrial scale. Food Chemistry, v. 150, p. 193-198, 2014.

FONTES, J. R. A. Manejo integrado de plantas daninhas. Planaltina, DF: Embrapa Cerrados, 2003. 48 p.

FONTES, M. P. F.; CAMARGO, O. A.; SPOSITO, G. Eletroquímica das partículas coloidais e sua relação com a mineralogia de solos altamente intemperizados. Scientia Agricola, v. 58, p. 627-646, 2001.

GALDÁMEZ, E. V. C. Aplicação das técnicas de planejamento e análise de experimentos na melhoria da qualidade de um processo de fabricação de produtos plásticos. 2002. 133 f. Dissertação (Mestrado) - Escola de Engenharia de São Carlos, Universidade de São Paulo, São Carlos, 2002. 
GANZERA, M.; EGGER, C.; ZIDOM, C.; STUPPNER, H. Quantitative analysis of flavonoids and phenolic acids in Arnica Montana L by micellar electrokinetic capillary chromatography. Analitica Chimica Acta, v. 614, p. 196-200, 2008.

GAROFULIC, I. E.; DRAGOVIC-UZELAC, V.; JAMBRAK, A. R.; JUKIC, M. The effect of microwave assisted extraction on the isolation of a anthocyanins and phenolic acids from sour cherry Marasca (Prunus cerasus var. Marasca). Journal of Food Engineering, v. 117, p. 437-442, 2013.

GEVAO, B.; SEMPLE, K.T.; JONES, K.C. Bound pesticide residues in soil: a review. Enviromental Pollution, v.108, p. 3-14, 2000.

GOLSTEIN, P.; AUBRY. L.; LEVRAUD, J. P. Cell-death alternative model organisms: why and which? Nature Reviews Molecular Cell Biology, v. 4, p. 798-80, 2003.

GRAYER, R.; KOKUBUN, T. Plant-fungal interactions: the search for phytoalexins and other antifungal compounds from higher plants. Phytochemistry, v. 56, p. 253-263, 2001.

GUNATILAKA, A. A. L.; SOTHEESWARAN, S.; BALASUBRAMANIAM, S.;

CHANDRASEKARA, A.I.; SRIYANI, H.T.B. Studies on medical plants of Srilanka III: pharmacologically important alkaloids of Sida species. Planta Médica, v. 39, p.66-72, 1980.

GWYNNE, D. C.; MURRAY, R. B. Weed biology and control in agriculture and horticulture. London: Batsford Academic and Educational, 1985. 258 p.

HAHN, M. G. Microbial elicitors and their receptors in plants. Annual Review of Phytopathology, v. 34, p. 387-412, 1996.

HAMMERSCHMIDT, R. Phytoalexins: What have we learned after 60 years?. Annual Review of Phytopathology, v. 37, p. 285-306, 1999.

HARBONE, J. B. Phenolics compounds. In HARBONE, J. B (Ed.). Phytochemical methods: a guide to modern techniques of plants analysis. London: Chapman and Hall, 1998. p. $40-106$

HERNANDEZ-RODRIGUEZ, D.; SÁNCHEZ, J. E.; GUERRA NIETO, M.; MÁRQUEZROCHA, F. J. Degradation of endosulfan during substrate preparation and cultivation of Pleurotus pulmonarius. World Journal Microbiology and Biotechnology, v.22, p. 753-760, 2006. 
HUBERT, J.; BERGER, M.; NEPVEU, F.; PAUL, F.; DAYDÉ, J. Effects of fermentation on the phytochemical composition and antioxidant properties of soy germ. Food Chemistry, v.109, p.709-721, 2008.

INSTITUTO BRASILEIRO DE GEOGRAFIA E ESTATÍSTICA (IBGE). SISTEMA IBGE DE RECUPERAÇÃO AUTOMÁTICA (SIDRA). Brasil, série histórica de área plantada; série histórica de produção agrícola; safras 1998 a 2011. 2012. Disponível em <www.sidra.ibge.gov.br/bda/agric>. Acesso em: 14 abr. 2016.

INSTITUTO NACIONAL DE METROLOGIA NORMALIZAÇÃO E QUALIDADE INDUSTRIAL (INMETRO). Orientações sobre validação de métodos de ensaios químicos. São Paulo, 2003. 19 p.

INTERNACIONAL PLANT NUTRITION INSTITUTE (IPNI). Nutri-Facts, Agronomic fact sheets on crop nutrients. Nitrogen, n. 1, p. 14024, 2015.

INTERNACIONAL PLANT NUTRITION INSTITUTE (IPNI). Nutri-Facts, Phosphorus, n. 2, p. 14025, 2015.

INTERNACIONAL PLANT NUTRITION INSTITUTE (IPNI). Nutri-Facts, Potassium, n. 3, p. 14026, 2015.

INTERNACIONAL PLANT NUTRITION INSTITUTE (IPNI). Nutri-Facts, Calcium, n. 5, p. 15040, 2015.

JUNG, V.; OLSSON, E.; CASPERSEN, S.; ASP, H.; JENSÉN, P.; ALSANIUS, B. W. Response of young hydroponically grown tomato plants to phenolic acids. Scientia Horticulturae, v. 100, p. 23-37, 2004.

JURAN, J. M.; GRYNA JUNIOR., F. M; BINGHAM JUNIOR., R. S. Quality control handbook. 3a ed. New York: McGraw-Hill, 1951. Cap. 27, p. 1-49,

JUSTESEN, U.; KNUTHSEN, P. Composition of flavonoids in fresh herbs and calculation of flavonoids intake by use of herbs in tradicional Danish dishes. Food Chemistry, v. 73, p.245250,2001

KERR, J. F.; WYLLIE, A. H.; CURRIE, A. R. Apoptosis: a basic biological phenomenon with wide ranging implications in tissue kinetics. British Journal of Cancer, v. 26, p. 239257, 1972. 
KOSKINEN, W. C.; HARPER, S. S. The retention process: mechanisms. In: CHENG, H. H. (Ed). Pesticides in the soil environment: processes, impacts, and modeling. Madison, USA: Soil Science Society of America, 1990. p. 51-77.

LARA, J. F.; MACEDO, J. F.; BRANDÃO, M. Meadow holm pasture wedds in fields in State of Minas Gerais. Planta Daninha. v. 21, p. 11-20, 2003.

LARHED, M.; HALLBERG, A. Microwave-assisted high-speed chemistry: a new technique in drug discovery. Drug Discovery Today, v. 6, p. 406-416, 2001.

LEE, J. H.; CHO, K. M. Changes occurring in compositional components of black soybeans maintained at room temperature for different storage periods. Food Chemistry, v.131, p. 161$169,2012$.

LEE, J. H.; KANG, N. S.; SHIN, S. O.; SHIN, S. H.; LIM, S. M.; SUH, D. Y.; BAEK, I. Y.; PARK, K. Y.; HA, T. J. Characterization of anthocyanins in the black soybean (Glycine max L.) by HPLC-DAD-ESI/MS analysis. Food Chemistry, v.112, p.226-231, 2009.

LI, J.; ZU, Y. G.; FU, Y. J.; YANG, Y. C.; LI, Z. N.; WINK, M. Optimization of microwaveassisted extraction of triterpene saponins from defatted residue of yellow horn (Xanthoceras sorbifolia Bunge) kernel and evaluation of it antioxidant activity. Innovative Food Science Emerging technologies, v. 11, p. 637-643, 2010.

LINDERMAN, R. G.; DAVIS, E .A. Evaluation of commercial inorganic and organic fertilizer effects on arbuscular mycorrhizae formed by Glomus intraradices. Horticulturae Technology, v. 14, p. 196-202, 2004.

LOCHER, R.; MARTIN, H. V.; GRISON, R.; PILET, P. E. Cell wall-bound trans- and cisferulic acids in growing maize roots. Physiologia Plantarum, v. 90, p. 1219-1232, 1994.

LONDRES, F. Agrotóxicos no Brasil: um guia par ação em defesa da vida. Rio de Janeiro: Assessoria de Serviços a Projetos e Agricultura Alternativa, 2011. 190 p.

LORENZI, H. Plantas medicinais no Brasil: nativas e exóticas. Nova Odessa, SP: Plantarum, 2002. 544 p.

LORENZI, H. Plantas daninhas do Brasil: terrestres, parasitas, aquáticas e tóxicas. 3.ed. Nova Odessa, SP: Instituto Plantarum, 2000. 608 p. 
LUTTERODT, G. D. Responses of gastrointestinal smooth muscle preparation to a muscarinic principle present in Sida veronicaefolici. Journal of Ethnopharmacology. v. 23, p. 313-322, 1988.

MARASHIM-SILVA, F.; AQUILA, M. E. A. Contribuition to the study of nature species allelopathic potencial. Revista Árvore, Viçosa, v. 30, p. 547-555, 2006.

MARCHI, G; MARCHI, E. C. S.; GUIMARÃES, T. G. Herbicidas: mecanismos de ação e uso. Planatina, DF. Embrapa Cerrados, 2008. 36p.

MARIA, I. C.; ROSSETTO, R.; AMBROSANO, E. J.; CASTRO, O. M.; NEPTUNE, A. M. L. Efeito da adição de diferentes fontes de cálcio no movimento de cátions em colunas de solo. Scientia agrícola, v. 50, n. 1, p. 87-98, 1993.

MATOS, F. O.; CASTRO, R. M. S.; RUIVO, M. L. P.; MOURA, Q. L. Teores de nutrientes do solo sob sistema agroflorestal manejado com e sem queima do estado do Pará. Floresta e Ambiente, v. 19, n. 3, p. 257-266, 2012.

MEDEIROS, J. C.; ALBUQUERQUE, J. A.; MAFRA, A. L.; ROSA, J. D.; GATIBONI, L. C. Relação cálcio: magnésio do corretivo da acidez do solo na nutrição e no desenvolvimento inicial de plantas de milho em um Cambissolo Húmico Álico. Semina: Ciências Agrárias, v. 29, n. 4, p. 799-806, 2008.

MENDES, I. S. Avaliação dos extratos das folhas e sementes de feijão-de-porco (Canavalia ensiformis) aplicados como bioerbicidas pós-emergentes e identificação de aleloquímicos via cromatografia liquida de alta eficiência (HPLC). 2011. 74 f. Dissertação (Mestrado) - Instituto de Química de São Carlos, Universidade de São Paulo, São Carlos, 2011.

MENDES, I. S.; REZENDE, M. O. O. Assessment of the allelopathic effect of leaf and seed extracts of as postemergent bioherbicides: A green alternative for sustainable agriculture. Journal of Environmental Science and Health. Part B. Pesticides, Food Contaminants, and Agricultural Wastes, v. 49, p. 374-380, 2014

MENDONÇA, R. L. Determinação de aleloquímicos por HPLC/UV-Vis em extratos aquosos de sementes de Canavalia ensiformis e estudo da atividade alelopática. 2008. 100 f. Dissertação (mestrado) - Instituto de Química de São Carlos, Universidade de São Paulo, São Carlos, 2008. 
MILONE, G. Estatística geral e aplicada. São Paulo: Centage Learning, 2009. 240 p.

MINISTÉRIO DA AGRICULTURA, PECUÁRIA E ABASTECIMENTO (MAPA). Agrotóxicos. 2015. Disponível em: <http://www.agricultura.gov.br/vegetal/mercadointerno/agrotoxicos>. Acesso em: 03 mar. 2016.

MINITAB STATISTICAL SOFTWARE. What is ANOVA. 2014. Disponível em: $<$ http://support.minitab.com/pt-br/minitab/17/topic-library/modelingstatistics/anova/basics/what-is-anova/>. Acesso em: 23 fev. 2016.

MOLINA, M. R.; ARGUETA, C. E.; BRESSANI, R. Extraction of nitrogenous constituents from the Jack bean (Canavalia ensiformis). Journal of Agricultural and Food Chemistry, v. 22, p. 309-312, 1974.

MOLNÁR-PERL, I.; FÜZFAI, Z. Chromatographic, capillary electrophoretic and capillary electrochromatographic techniques in the analysis of flavonoids. Journal of

Chromatography A, v. 1073, n. 1-2, p. 201-227, 2005.

MONTGOMERY, D. C. Diseño y análisis de experimentos. Tradução de Jaime Delgado Saldivar. México: Iberoamérica, 1991. 692 p.

B. NETO, B.; SCARMINIO, I. S.; BRUNS, R. E. Como fazer experimentos: pesquisa e desenvolvimento na ciência e na indústria. Campinas, Editora da Unicamp, 2001. 412 p.

OMAR, S. H. Oleuropein in olive and its pharmacological effects. Scientia Pharmaceutica, v. 78, p. 133-154, 2010.

OLIVEIRA, M. F.; BRIGHENTI, A. M. Comportamento dos herbicidas no ambiente. In: OLIVEIRA JÚNIOR, R. S.; CONSTANTIN, J.; INQUE, M. H. (Ed.). Biologia e manejo de plantas daninhas. Curitiba: EMBRAPA, 2011. Cap. 11, p. 264-364.

ORIGINLAB. Origin 8 User Guide. Version v.80724 (B724). Northamptom. OriginLab, 2007. Programa de computador.

OSAKI, F. Calagem e adubação. Campinas: Instituto Brasileiro de Ensino Agrícola, 1991. $503 \mathrm{p}$.

PAIVA, L. B.; GOLDBECK, R.; SANTOS, W. D.; SQUINA, F. M. Ferulic acid and derivatives: molecules with potencial application in the pharmaceutical field. Brazilian Journal of Pharmaceutical Sciences, v. 49, n. 3, p. 395-411, 2013. 
PETERSON, D. E.; THOMPSON, C. R.; REGEHR, D. L.; AL-KHATIB, K. Herbicide mode of action. Topeka: Kansas State University, 2001. 24 p.

PIRES, N. M.; OLIVEIRA JR., R. S.; PAES, J. M.V.; SILVA, E. Avaliação do impacto ambiental causado pelo uso de herbicidas. Viçosa: Sociedade de Investigações Florestais, 1995. 22 p. (Boletim Técnico SIF, 11)

PORNPROM, T.; SUKCHAROENVIPHARAT, W.; SANSIRIPHUN, D. Weed control with pre-emergence herbicides on vegetable soybean (Glycine max L. Merrill). Crop Protection. v. 29, p.684-690, 2010.

PORTAL BRASIL. Produção de soja se aproxima de 100 milhões de toneladas. 2015. Disponível em: <http://www.brasil.gov.br/economia-e-emprego/2015/09/producao-de-sojase-aproxima-de-100-milhoes-de-toneladas\#>. Acesso em: 12 fev. 2016.

POTTER, K. N.; TORBERT, H. A.; MORRISON JUNIOR, J. E. Tillage and residues effects on infiltration and sediment losses on vertisols. Transactions of the ASAE, v. 38, p. 14141419, 1995.

PRAKASH, A.; VARMA, R. K.; GHOSAL, S. Alkaloid constituents of Sida acuta, S. humilis, S. rhombifolia and S. spinosa. Planta Medica. v. 43, p. 384-388, 1981.

PROCHNOW, L. I. Avaliação e manejo da acidez do solo. Informações Agronômicas, n. 146. 2014. Disponível em:

<http://www.abracal.com.br/arquivos/documentos/IPNI_Avaliação\%20e\%20Manejo\%20da\% 20Acidez\%20do\%20Solo_jun2014-1.pdf>. Acesso em: 23 fev. 2015.

PROESTOS, C.; SERELI, D.; KOMAITIS, M. Determination of phenolic compounds in aromatic plants by RP-HPLC and GC-MS. Food Chemistry, v. 95, p.44-52, 2006.

PROESTOS, C.; KOMAITIS, M. Application of microwave- assisted extraction to the fast extraction of plant phenolic compounds. LWT, v. 41, p.652-659, 2008.

QIU, X. H.; BAI, W. Q.; ZHONG, Q. Z.; LI, M.; HE, F. Q.; LI, B. T. Isolation and characterization of bacterial strain of the genus Ochrobactrum with methyl parathion mineralizing activity. Journal of Applied Microbiology, v.101, p.986-994, 2006. 
RAUA, J.-P.;REMES, S.; HEINONEN, M.; HOPIA, A.; KAHKONEN, M. KUJALAC, Y.; PIHLAJAC, K.; VUORELA, H.; VUORELA, P. Antimicrobial effects of Finish plant extracts containing flavonoids and other phenolic compounds. Internacional Journal Food Microbiology, v. 56, p. 3-12, 2000.

RECHNER, A. R.; PANNALA, A. S.; RICE-EVANS, C. A. Caffeic acid derivates in artichoke extract are metabolized to phenolic acids in vitro. Free Radical Reseach, v. 35, n. 2, p. 195-202, 2001.

RICE-EVANS, C. A.; MILLER, N. J.; PAGANGA, G. Antioxidant properties of phenolics compounds. Trend in Plants Science, v.2, p. 152-159, 1997.

RIJKE, E.; OUT, P.; NIESSEN, W. M. A.; ARIESE, F.; GOOIJER, C.; BRINKMAN, U. A. TH. Analytical separation and detection methods of flavonoids. Journal of Chromatography A, v. 1112, n. 1-2, p. 31-63, 2006.

ROCKENBACH, I. I. Compostos fenólicos, ácidos graxos e capacidade antioxidante do bagaço da vinificação de uvas tintas (Vitis vinifer L. e Vitis labrusca L.). 2008. 113 f. Dissertação (Mestrado) - Centro de Ciências Agrárias, Universidade Federal de Santa Catarina, Florianopólis, 2008.

RONHEDE, S.; SEBASTIAN, B.; SORENSEN, R.; JENSEN, B.; AAMAND, J. Mineralization of hydroxylated isoproturon metabolites produced by fungi. Soil Biology and Biochemistry, v. 39, p. 1751-1758, 2007.

ROSA, R.; SANO, E. E.; ROSENDA, J. S. Estoque de carbono em pastagens cultivadas na bacia hidrográfica do Rio Paranaíba. Sociedade \& Natureza, v. 26, n. 2, p. 333-351, 2014.

ROSS, M. A.; CHILDS, D. J. Herbicide mode-of-action summary. West Lafayette: Purdue University, $1998.11 \mathrm{p}$.

RUEDA, A.; ROMAN, Y.; LOBO, M.; PELAEZ, C. Analysis of tomato seedling cell death in response to copper and paraquat induction. Tropical Plant Pathology, v. 36, n. 3, p. 169-177, 2011.

RUMBOLD, K.; BIELY, P.; MASTIHUBOVA, M.; GUDEL, J.; GUBITZ, G.; ROBRA, K. H.; PRIOR, B. A. Purification and properties of a feruloyl esterase involved in lignocellulose degradation by Aureobasidium pullulans. Applied and Environmental Microbiology, v. 69, n. 9, p. 5622-5626, 2003. 
SANTOS, S. Potencial alelopático e avaliação sistemática de compostos secundários em extratos provenientes de Canavalia ensiformis utilizando eletroforese capilar. 2004. 185 f. Tese (Doutorado) - Instituto de Química de São Carlos, Universidade de São Paulo, São Carlos, 2004.

SANTOS, W. D.; FERRARESE, M. L. L.; NAKAMURA, C.V.; MOURÃO, K. S. M.; MANGOLIN, C. A.; FERRARESE-FILHO, O. Soybean (Glycine max) root lignification induced by Ferulic Acid. The possible mode of action. Journal of Chemical Ecology, v. 34, $\mathrm{n}^{\circ}$ 9, p.1230-1241, 2008.

SANTOS, S.; MORAES, M. L.; SOUZA FILHO, A. P. S.; REZENDE, M. O.O. Allelopathic potential and systematic evaluation of organic extracts from Canavalia ensiformis leaves (Jack beans). Journal Environmental Science Health B, v. 40, n. 1, p. 77-84, 2005.

SANTOS, S.; MORAES, M.L.L.; SILVA-FILHO, A.P.S.; REZENDE, M.O.O. Potencial alelopático e avaliação sistemática de compostos secundários em extratos provenientes das folhas de Calopogonium mucunoides. Anais Associação Brasileira de Química, v. 52, n. 4, p. 43-47, 2005.

SANTOS, S.; MORAES, M. L. L.; REZENDE, M. O. O. Allelopathic potential and systematic evaluation of secondary compounds in extracts from roots of Canavalia ensiformis by capillary electrophoresis. Eclética Química (Araraquara), v. 32, p. 13-18, 2007.

SCAPINI, C. A.; REINERT, D. J.; SILVA, V. R.; ZANETTE, A. Evolução da estabilidade estrutural de solo degradado por dois anos de preparo convencional e plantio direto contínuo. In: REUNIÃO BRASILEIRA DE MANEJO E CONSERVAÇÃO DO SOLO E DA ÁGUA, 12., 1998, Fortaleza. Anais... Ceará, 1998. p. 177-178.

SERVILI, M.; ESPOSTO, S.; FABIANI, R.; URBANI, S.; TATICCHI, A.; MARIUCCI, F.; SELVAGGINI, R.; MONTEDORO, G. F. Phenolics compounds in olive oil: Antioxidant, health and organoleptic activities according to their chemical struture.

Inflammopharmacology, v. 17, p. 76-84, 2009.

SFREDO, G. J. Soja no Brasil: Calagem, adubação e nutrição mineral. Londrina: Empresa Brasileira de Pesquisa e Agropecuária, Embrapa Soja, 2008.148 p.

SHAH, M. D.; HOSSAIN, M. A. Total flavonoids content and biochemical screening of leaves of tropical endemic medicinal plants Merremia borneeensis. Arabian Journal of Chemistry, v.7, p.1034-1038, 2014.

SHAHIDI, F.; WANASUNDARA,P. K. J. P. D. Phenolic antioxidants. Critical Reviews in Food Science and Nutrition, v. 32, p. 67-103, 1992. 
SHANN, J. R.; BOYLE, J. J. Influence of plant species on situ rhizosphere degradation. In: ANDERSON, T. A.; COATS, J. R. (Ed.). Bioremediation through Rhizosphere Tecnology. Washington: American Chemical Society, 1994. p. 70-81. (ACS Symposium Series, 563).

SHIMIZU, S.; KANASEKI, T.; MIZUSHIMA, N.; ARAKAWA-KOBAYASHI, S.; THOMPSOM, C. B.; TSUJIMOTO, Y. Role of Bcl-2 family proteins in a non-apoptotic programmed cell death dependent on autophagy genes, Natural Cellular Biology, v. 6, p. 1221-1228, 2004.

SHYLESH, B. S.; NAIR, S. A.; SUBRAMONIAM, A. Induction of cell-specific apoptosis and protection from Dalton's lymphoma challenge in mice by an active fraction from Emilia sonchifolia. Indian Journal of Pharmacology, v. 37, p. 232-237, 2005.

SILVA, D. F.; AZEVEDO, E. B.; REZENDE, M. O. O. Optimization of microwave-assisted extraction of a bioherbicide from Canavalia ensiformis leaves. American Journal of Environmental Sciences, v.12, n.1, p. 27-32, 2016.

SILVA, F. M.; AQUILA, M. E. A. Contribuição ao estudo do potencial alelopático de espécies nativas. Revista Árvore (Visçosa-MG), v. 30, p. 547-555, 2006.

SILVA, D. D.; PRUSKI, F. F. Recursos hídricos e desenvolvimento sustentável da agricultura. Viçosa: MMA, 1997. 252 p.

SINDICATO NACIONAL DAS INDÚSTRIAS DE DEFENSIVOS AGRÍCOLAS (SINDAG). Vendas de defensivos agrícolas são recordes e vão a USS\$ 8,5 bi em 2011. 2012. Disponível em: <http://www.sindag.com.br/noticia.php?News_ID=2256>. Acesso em: 14 abr. 2016.

SINDICATO NACIONAL DAS INDÚSTRIAS DE DEFENSIVOS AGRÍCOLAS (SINDAG). Dados de produção e consumo de agrotóxicos. 2012. Disponível em: <www.sindag.com.br>. Acesso em: 14 abr. 2016.

SINGH, A.; GHOSHAL, N. Impact of herbicides and various soil amendments on soil enzymes activities in a tropical rainfed agroecosystem. European Journal of Soil Biology, v. 54, p. 56-62, 2013.

SIQUEIRA, J. O.; NAIR, M. G.; HAMMERSCHMIDT, R.; SAFIR, G. R. Significance of phenolic compounds in plant-soil-microbial systems. Critical Reviews in Plant Sciences, v.10, p. 63-121, 1991. 
SKOOG, D. A.; HOLLER, F. J.; NIEMAN, T. A. Princípios de análise instrumental. São Paulo: Bookman, 2006. 836 p.

SOCIEDADE BRASILERA DA CIÊNCIA DAS PLANTAS DANINHAS (SBCPD)-. Procedimento para instalação e análise de experimentos com herbicidas. Londrina: SBCPD. 1995. 42 p.

SONG, J.; LI, D.; LIU, C.; ZHANG, Y. Optimized microwave-assisted extraction of total phenolics (TP) from Ipomoea batatas leaves and its antioxidant activity. Innovative Food Science and Emerging Technologies, v. 12, p. 282-287, 2011.

SPARLING, G. P.; ORD, B. G.; VAUGHAN, D. Changes in microbial biomass and activity in soil amended with phenolic acids. Soil Biology and Biochemistry, v. 13, p. 455-460, 1981.

TEPE, B.; DAFERERA, D.; SOKMEN, M.; POLISSIOU, M.; SOKMEN, A. In vitro antimicrobial and antioxidant activities of the essential oils and various extract of Thymus eigii. Journal of Agricultural Food Chemistry, v. 52, p. 1132-1137, 2004.

TIGRE, R. C.; PEREIRA, E. C.; SILVA, N. H.; VICENTE, C.; LEGAZ, M. E. Potential phenolic bioherbicides from Cladonia verticillaris produce ultrastructural changes in Lactuca sativa seedlings. South African Journal of Botany, v. 98, p. 16-25, 2015.

TSUJIMOTO, Y. Cell death regulation by the Bcl-2 protein family in the mitochondria, Journal Cellular Physiology, v. 195, p. 158-67, 2003.

TSUKUI, A.; REZENDE, C. M. Extração assistida por micro-ondas e química verde. Revista Virtual de Química, v. 6, n. 6, p. 1713-1725, 2014.

TORRES-RODRÍGUES, D. A.; ROMERO-IBARRA, I. C.; IBARRA, I. A.; PFEIFFER, H. Biodiesel production from soybean and Jatropha oils using cesium impregnated sodium zirconate as a heterogeneous base catalyst. Renewable Energy, v. 93, p. 323-331, 2016.

TURNER, J. A.; RICE, E. L. Microbial decomposition of ferulic acid in soil. Journal of Chemical Ecology, v. 1, p. 41-58, 1975.

UNIÃO BRASILEIRA DO BIODISEL E BIOQUEROSENE (UBRABIO). Biodiesel de soja polui 70\% menos do que o diesel. 2014. Disponível em:

<http://www.ubrabio.com.br/1891/documentos/biodieseldesojapolui70menosdoquediesel_183 760/>. Acesso em: 14 abr. 2016. 
UPADHYAY, R.; RAMALAKSHMI, K.; RAO, L. J. M. Microwave-assisted extraction of chlorogenic acids from coffee beans. Food Chemistry, v. 130, p. 184-188, 2012.

VIDAL, R. Herbicidas: mecanismos de ação e resistência de plantas. Porto Alegre: Ed. do autor, 1997. $165 \mathrm{p}$.

VIEIRA, S. Análise de variância: ANOVA. São Paulo: Atlas, 2006. 588 p.

VOLL, E.; GAZZIERO, D. L. P.; BRIGHENTI, A. M.; ADEGAS, F. S.; GAUDÊNCIO, C. A.; VOLL, C. E. A dinâmica das plantas daninhas e práticas de manejo. Londrina:

Embrapa soja, 2005. 85 p.

ZAMBROSI, F. C. B.; ALLEONI, L. R. F.; CAIRES, E. F. Teores de alumínio trocável e não trocável após calagem e gessagem em latossolo sob sistema plantio direto. Bragantia, v .66, n.3, p. 487-495, 2007.

ZHANG, D-Y.; ZU, Y-G.; FU, Y-J.; WANG, W.; ZHANG, L.; LUO, M.; MU, F-S.; YAO, $\mathrm{X}-\mathrm{H}$.; DUAN, M-H. Aqueous two-phase extraction and enrichment of two main flavonoids from pigeon pea roots and the antioxidant activity. Separation and purification Technology, v. 102, p. 26-33, 2013.

ZHAOA, T.; DAVIS, L.; VERPOORTEC, R. Elicitor signal transduction leading to production of plant secondary metabolites. Biotechnology Advances, v. 23, p. 283-333, 2005.

ZHOU, W.; YUAN, J. Necroptosis in health and diseases, Seminars in cell and developmental biology. Seminars in Cell and Development Biology, v. 35 p. 14-23, 2014.

ZHOU, X.; WU, F. Effects of amendments of ferulic acid on soil microbial communities in the rhizosphere of cucumber (Cucumis sativus L.). European Journal of Soil Biology, v. 50, p.191-197, 2012.

ZUO, Y.; WANG, C.; ZHAN, J. Separation, characterization, and quantification of benzoic and phenolic antioxidants in American cranberry juice by GC-MS. Journal of Agricultural and Food Chemistry, v.50, p. 3789-3794, 2002.

WAGNER, E. P.; LAMBERT, P. D.; MOYLE, T. M.; KOEHLE, M. A. Diesel vehicle performance on unaltered waste soybean oil blended with petroleum fuels. Fuel, v. 107, p. 775-765, 2013. 
WALTON, B. T.; HOYLMAN, A. M.; PEREZ, M. M.; ANDERSON, T. A.; JOHNSON, T. R.; GUTHRIE, E. A.; CHRISTIMAN, R. F. Rhizosphere microbial communities as a plant defense against toxic substances in soil. In: ANDERSON, T. A.; COATS, J. R. (Ed.).

Bioremediation through rhizosphere tecnology, Washington: American Chemical Society, 1994. p. 82-92. (ACS Symposium Series, 563).

WANG, L. J.; WELLER, C. L. Recent advances in extraction of natural products from plants. Trends in Food Science and Technology, v. 17, p. 300-312, 2006.

WANG, H.; DING, J.; REN, N. Recent advances in microwave-assisted extraction of trace organic pollutants from food and environmental samples. Trends in Analytical Chemisty, v. 75, p. 197-208, 2016.

WU, H-S.; LUO, J.; RAZA, W.; LIU, Y-X.; GU, M.; CHEN, G.; HU, X-F.; WANG, J-H.; MAO, Z-S.; SHEN, Q-R. Effects of exogenously added ferulic acid on in vitro Fusarium oxysporum f. sp. niveum. Scientia Horticulturae, v. 124, p. 448-453, 2010.

YAMASHITA, O. M.; GUIMARÂES, S. C.; SILVA, J. L.; CARVALHO, M. A. C.; CAMARGO, M. F. Fatores ambientais sobre a germinação de Emilia sonchifolia. Planta Daninha, Viçosa-MG, v. 27, n. 4, p. 673-681, 2009.

YIN, X.; DUAN, X.; YOU, Q.; DAI, C.; TAN, Z.; ZHU, X. Biodiesel production from soybean deodorizer distillated using calcined duck eggshell as catalyst. Energy Conversion and Management, v. 112, p. 199-207, 2016. 


\section{ANEXOS}

Anexo A- Classificação dos solos

Anexo B- Classificação dos herbicidas quanto à forma de aplicação e aos mecanismos de ação 


\section{ANEXO A - Classificação dos solos}

A definição de classes deve ter por base características diretamente relacionadas com o crescimento de plantas, principalmente o que concerne ao desenvolvimento radicular, relações solo-água-planta e propriedades importantes nas interpretações para fins de engenharia, geotecnia e ambientais. Os nomes das treze classes são formados pela associação de um elemento formativo com a terminação "ssolos". A Tabela 1 apresenta os nomes das classes e os respectivos significados.

Tabela 1 - Nomenclatura da classificação dos solos

\begin{tabular}{|c|c|}
\hline Classe & Significados \\
\hline ARGISSOLO & $\begin{array}{l}\text { Argila. Acumulação de argilas (de baixa ou } \\
\text { alta atividade) }\end{array}$ \\
\hline CAMBISSOLO & $\begin{array}{l}\text { Cambiare- trocar ou mudar. Horizonte B } \\
\text { incipiente. }\end{array}$ \\
\hline CHERNOSSOLO & Preto, rico em matéria orgânica. \\
\hline ESPODOSSOLO & Spodos- cinza vegetal. Horizonte B espódico. \\
\hline GLEISSOLO & Glei. Horizonte glei \\
\hline LATOSSOLO & $\begin{array}{l}\text { Lat- material muito alterado. Horioznte B } \\
\text { latossólico. }\end{array}$ \\
\hline NEOSSOLO & Novo. Pouco desenvolvimento genético. \\
\hline NITOSSOLO & Nitidus- brilhante. Horizonte B nítido. \\
\hline ORGANOSSOLO & Orgânico. Horizonte H ou O hístico. \\
\hline PLANOSSOLO & Planus. Horizonte B plânico. \\
\hline PLINTOSSOLO & Plinthus. Horizonte plíntico. \\
\hline VERTISSOLO & Vertere- inverter. Horizonte vértico. \\
\hline
\end{tabular}

Fonte: EMBRAPA, 2006. 
A seguir são apresentadas as definições de horizontes diagnósticos superficiais e subsuperficiais do solo, segundo Embrapa (2006):

\section{Horizontes diagnósticos superficiais}

\section{Horizonte Hístico}

Horizonte constituído predominantemente de material orgânico contendo $80 \mathrm{~g} \mathrm{~kg}^{-1}$ ou mais de carbono orgânico, resultante de acumulações de resíduos vegetais depositados superficialmente, ainda que, possa ser encontrado recoberto por horizontes ou depósitos minerais e mesmos por camadas orgânicas mais recentes. Compreende materiais depositados no solo sob condições de excesso de água, por longos períodos ou durante todo o ano.

\section{Horizonte A Chernozêmico}

Horizonte mineral superficial, relativamente espesso, de cor escura, com alta saturação por bases. A estrutura do solo é suficientemente desenvolvida, com agregação e grau de desenvolvimento moderado ou forte. A saturação por bases é de $65 \%$ ou mais, com predomínio do íon cálcio e/ou magnésio. O conteúdo de carbono orgânico é de $6 \mathrm{~g} \mathrm{~kg}^{-1}$ ou mais em todo o horizonte.

\section{Horizonte A Proeminente}

Possuem características próximas às do horizonte A chernozêmico, no que se refere a cor, teor de carbono orgânico, consistência, estrutura e espessura, diferindo apenas na saturação por bases que é inferior a $65 \%$.

\section{Horizonte A Húmico}

É um horizonte mineral, com solo úmido e saturação por bases inferior a $65 \%$, apresentando espessura e conteúdo de carbono orgânico dentro dos limites específicos de espessura mínima igual ao horizonte A chernozêmico $(10 \mathrm{~cm})$ e teor de carbono orgânico igual ao limite mínimo do horizonte hístico $\left(80 \mathrm{~g} \mathrm{~kg}^{-1}\right)$. 


\section{Horizonte A Antrópico}

É um horizonte formado ou modificado pelo uso continuo do solo, como lugar de residência ou cultivo, por longos períodos, com adição de material orgânico em mistura ou não com material mineral, em alguns casos com fragmentos de cerâmica e restos de ossos. Possui características semelhantes ao horizonte A chernozêmico ou A húmico e difere por destes por apresentar teor de $\mathrm{P}_{2} \mathrm{O}_{5}$ solúvel em ácido cítrico mais elevado que na parte inferior do solo.

\section{Horizonte A Fraco}

É um horizonte fracamente desenvolvido, seja pelo reduzido teor de coloides ou orgânicos ou por condições externas de clima e vegetação, como as que ocorrem na zona semiárida com vegetação de caatinga. Caracteriza-se pela estrutura dos grãos simples, maciça ou com grau fraco de desenvolvimento; teor de carbono orgânico inferior a $6 \mathrm{~g} \mathrm{Kg}^{-1}$ ou espessura menor eu $5 \mathrm{~cm}$.

\section{Horizonte A Moderado}

Este horizonte não se enquadra nas definições dos demais horizontes superficiais. Em geral, este horizonte difere dos horizontes A chrenozêmico, proeminente e húmico pela espessura e/ou pela cor e do horizonte A fraco pelo teor de carbono orgânico e estrutura.

\section{Horizontes diagnósticos subsuperficiais}

\section{Horizonte B textural}

Horizonte mineral subsuperficial com textura franco arenosa ou mais fina, onde houve incremento de argila (fração $<0,002 \mathrm{~mm}$ ). Este horizonte pode ser encontrado à superfície e o solo foi parcialmente truncado por erosão. A natureza coloidal da argila a torna susceptível de mobilidade com a água no solo se a percolação for relevante. A cerosidade é constituída por revestimento de materiais coloidais minerais que, se bem desenvolvidos, são facilmente perceptíveis pelo aspecto lustroso e brilho graxo. 


\section{Horizonte B Latossólico}

Horizonte mineral subsuperficial, cujos constituintes evidenciam avançado estágio de intemperização, caracterizada pela alteração quase completa dos minerais primários menos resistentes ao intemperismo e/ou de minerais de argila. Em geral, é constituído por quantidades variáveis de óxidos de ferro e de alumínio, minerais de argila, quartzo e outros minerais mais resistentes ao intemperismo. O horizonte B latossólico pode apresentar fraca cerosidade. Pode conter mais argila do que o horizonte sobrejacente, porem o incremento da fração argila com o aumento da profundidade é pequeno.

\section{Horizonte B Incipiente}

Horizonte subsuperficial, subjacente ao A, Ap ou AB, que sofreu alteração física e química em grau não muito avançado, mas suficiente para o desenvolvimento de cor ou de unidades estruturais. Dentre as principais características estão: espessura mínima de 10 cm; não apresentar consistência quebradiça quando úmido; apresentar dominância de cores amareladas e avermelhadas; textura franco-arenosa ou mais fina;

\section{Horizonte B Nítico}

É um horizonte não hidromórfico, de textura argilosa ou muito argilosa, sem incremento de argila do horizonte superficial, com espessura de $30 \mathrm{~cm}$ ou mais. A estrutura, de grau de desenvolvimento moderado a forte, é em blocos subangulares, angulares ou prismática, que pode ser composta por blocos. Apresentam superfícies normalmente reluzentes, o que se pode ser descrito como cerosidade.

\section{Horizonte B Espódico}

Horizonte mineral subsuperficial, com espessura mínima de $2,5 \mathrm{~cm}$, que apresenta acumulação iluvial (proveniente da remoção de partículas de outros horizontes) de matéria orgânica, associada a complexos de sílica-alumínio ou húmus-alumínio, podendo ou não conter ferro, com poucas evidências de matéria orgânica iluvial. Ocorre normalmente sobre qualquer tipo de horizonte A. 


\section{Horizonte B Plânico}

É um tipo de horizonte B textural, com ou sem caráter sódico, subjacente a horizontes A, apresentando transição abrupta para os horizontes suprajacentes, normalmente associada a mudança textural. Apresenta estrutura prismática, colunar ou em blocos angulares e subangulares grande ou médios; com cores acinzentadas ou escurecidas. Apresenta teores elevados de argila dispersa e pode ser responsável pela formação de lençol de água suspenso.

\section{Horizonte Álbico}

É um horizonte mineral comumente subsuperficial, no qual a remoção ou segregação de material coloidal mineral e orgânico progrediu até a formação de cor. A cor do horizonte é determinada principalmente pelas partículas primárias de areia e silte e não por seu revestimento. Apresenta espessura de no mínimo $1 \mathrm{~cm}$. O horizonte E álbico, normalmente precede um horizonte B espódico, B textural, B plânico, plíntico, glei, fragipã ou uma camada impermeável que restrinja a percolação da água.

\section{Horizonte B Plíntico}

O horizonte plíntico caracteriza-se pela presença de plintita em quantidade igual ou superior a $15 \%$ (por volume) e espessura de pelo menos $15 \mathrm{~cm}$. É um horizonte mineral que apresenta cores vermelhas, acinzentadas ou brancas. Possui textura franco-arenosa ou mais fina. A estrutura é variável, podendo ser maciça ou em forma de blocos fraca ou moderadamente desenvolvida. Quando seco, o horizonte plíntico apresenta-se compacto, extremamente duro; quando úmido, é firme, podendo ter partes extremamente firmes; quando molhado, a consistência varia de ligeiramente plástica a muito pegajosa.

\section{Horizonte B Concrecionário}

Horizonte constituído de $50 \%$ ou mais de material grosseiro com predomínio de petroplíntita, do tipo nódulos ou concreções de ferro ou de ferro e alumínio. Apresenta no mínimo $30 \mathrm{~cm}$ de espessura. 


\section{Horizonte B Litoplíntico}

O horizonte lipoplíntico é constituído por petroplintita contínua ou praticamente contínua, engloba uma seção do perfil do solo fraturada mas que tem o predomínio de blocos de petroplintita com tamanhos mínimos de $20 \mathrm{~cm}$. Apresenta espessura de $10 \mathrm{~cm}$ ou mais. Este horizonte impede a penetração das raízes e o livre fluxo de água.

\section{Horizonte Glei}

É um horizonte mineral subsuperficial ou eventualmente superficial, com espessura de $15 \mathrm{~cm}$ ou mais, com $15 \%$ de plintita e é caracterizado pela redução do ferro e prevalência do estado reduzido no todo ou em parte, devido água estagnada, com cores neutras ou próximas de neutra. É um horizonte fortemente influenciado pelo lençol freático, virtualmente livre de oxigênio dissolvido em razão da saturação por água durante o ano todo.

\section{Horizonte Glei}

É um horizonte mineral subsuperficial ou eventualmente superficial, com espessura de $15 \mathrm{~cm}$ ou mais, com $15 \%$ de plintita e é caracterizado pela redução do ferro e prevalência do estado reduzido no todo ou em parte, devido água estagnada, com cores neutras ou próximas de neutra. É um horizonte fortemente influenciado pelo lençol freático, virtualmente livre de oxigênio dissolvido em razão da saturação por água durante o ano todo.

\section{Horizonte Cálcico}

É formado pela acumulação de carbonato de cálcio. Apresenta espessura de $15 \mathrm{~cm}$ ou mais, é enriquecido com carbonato de cálcio secundário e contem $150 \mathrm{~g} \mathrm{Kg}^{-1}$ ou mais de carbonato de cálcio, contendo no mínimo $50 \mathrm{~g} \mathrm{Kg}^{-1}$ a mais de carbonato que o horizonte ou camada subjacente.

\section{Horizonte Petrocálcico}

É um horizonte continuo, resultante da consolidação e cimentação de um horizonte cálcico por carbonato de cálcio ou carbonato de magnésio. O horizonte é continuamente cimentado em todo o perfil, a tal ponto que fragmentos secos imersos em água no fraturam, 
nem desprendem pedaços. Quando seco, não permite a penetração da pá ou do trado, por ser extremamenteduro; quando úmido é extremamente firme.

\section{Horizonte B Sulfúrico}

Este horizonte possui $15 \mathrm{~cm}$ ou mais de espessura e é composto de material mineral orgânico cujo valor de $\mathrm{pH}$ em água é 3,5 ou menor, o que evidencia a presença do ácido sulfúrico. Um horizonte sulfúrico forma-se pela oxidação de materiais minerais ou orgânicos ricos em sulfetos, como resultado da drenagem, mais comumente artificial, apresentando condições de acidez altamente tóxicas para a maioria das plantas.

\section{Horizonte B Vértico}

É um horizonte mineral subsuperficial que, devido à expansão e contração das argilas, apresenta características pedológicas (ciência que estuda o solo) típicas. A textura mais comum varia de argilosa a muito argilosa, com uma faixa mínima de $300 \mathrm{~g} \mathrm{Kg}^{-1}$ de argila. O horizonte vértico pode coincidir com outros horizontes e apresentar cores escuras, acinzentadas, amareladas ou avermelhadas.

\section{Fragipã}

É um horizonte mineral subsuperficial, endurecido quando seco, contínuo ou presente em $50 \%$ ou mais do volume do outro horizonte, geralmente com textura média. Pode estar subjacente a um horizonte B espódico, B textural ou álbico. Tem conteúdo de matéria orgânica muito baixo e é aparentemente cimentado quando seco, tendo consistência dura ou extremamente dura. Quando úmido, é de fraca a moderada quebradicidade. O fragipã dificulta ou impede a penetração das raízes e da água no horizonte em que ocorre.

\section{Duripã}

É um horizonte mineral subsuperficial, cimentado, contínuo ou presente em $50 \%$ ou mais do volume de outro horizonte com grau variável de cimentação por sílica e podendo ainda conter óxido de ferro e carbonato de cálcio. Apresentam consistência firme quando úmido e quebradiços quando sujeitos a prologado umedecimento. É um horizonte que apresenta 
cimentação suficientemente forte, onde os fragmentos não se desfazem. Os revestimentos de sílica, presentes em alguns poros e em algumas faces estruturais, são insolúveis em solução de $\mathrm{HCl} 1 \mathrm{~mol} \mathrm{~L}^{-1}$, mesmo durante prolongado tempo de saturação. As raízes e a água não penetram na parte cimentada, a não ser ao longo de fraturas verticais que distanciam de $10 \mathrm{~cm}$ ou mais. A seguir são apresentados os conceitos para cada classe de solo.

\section{Argissolos}

Grupamento de solos com horizonte B textural, com argila de atividade baixa ou alta conjugada com saturação por bases baixa ou caráter alítico (referente ao teor de alumínio extraível). São de profundidade variável, desde forte a imperfeitamente drenados, de cores avermelhadas ou amareladas, sendo raramente acinzentadas. São solo que variam de forte a moderadamente ácidos. Tem evolução avançada com atuação incompleta do processo de ferratilização, em conexão com paragênese caulinítica-oxídica ou virtualmente caulinítica, ou com hidroxi-Al entre camadas, na vigência de mobilização de argila de parte mais superficial do solo, com acumulação em horizonte subsuperficial (EMBRAPA, 2006).

\section{Cambissolos}

Grupamento de solos pouco desenvolvidos com horizonte B incipiente. São solos de imperfeitamente drenados, de cor bruna ou bruna-amarelada até vermelho escuro, de alta e baixa atividade da fração argila. É originado da pedogênese pouco avançada evidenciada pelo desenvolvimento da estrutura do solo, alterações do material de origem espessa pela quase ausência da estrutura da rocha ou da estratificação dos sedimentos, croma mais alto, matrizes mais vermelhas ou conteúdo de argila mais elevado que os horizontes adjacentes (EMBRAPA, 2006).

\section{Chernossolos}

São grupamentos de solos com horizontes A chernozêmico, com argila de atividade alta e alta saturação por base, com ou sem acumulação de carbonato de cálcio. São solos normalmente pouco coloridos (escuros ou com pouca tonalidade), imperfeitamente drenados, apresentando caráter carbonático. São solos moderadamente ácidos a fortemente alcalinos, com argila de atividade alta, com capacidade de troca catiônica alta, com predomínio de cálcio e magnésio entre os cátions trocáveis. Teve evolução pouco avançada, segundo atuação 
expressiva de processo de bissalitização, manutenção de cátions básicos divalentes, principalmente o cálcio, conferindo alto grau de saturação dos coloides e eventual acumulo de carbonato de cálcio, promovendo reação aproximadamente neutra com enriquecimento em matéria orgânica, o que favorece a complexação e floculação de coloides minerais e orgânicos (EMBRAPA, 2006).

\section{Espodossolos}

São grupamentos de solos com B espódico. A textura do solo é predominantemente arenosa e raramente argilosa. São solos, em geral, muito pobres em fertilidade, moderada a fortemente ácidos, ocasionalmente com altos teores de alumínio extraível. Tem sua formação de processos de podzolização com eluviação de compostos de alumínio com ou sem ferro em presença de ácidos húmicos e consequente acumulo iluvial desses constituintes (EMBRAPA, 2006).

\section{Gleissolos}

São grupamentos de solos com expressiva gleização. São solos permanentes ou periodicamente saturados por água. Caracterizam-se pela forte gleização, em decorrência do ambiente redutor, livre de oxigênio dissolvido, em razão da saturação por agua durante todo o ano ou por longos períodos. O processo de gleização implica na manifestação de cores acinzentadas, azuladas ou esverdeadas devido à redução e solubilização do ferro. Sua formação é hidromórfica, expressa por forte gleização, resultante de processos de intensa redução de compostos de ferro, em presença de mateia orgânica, com ou sem alternância de oxidação, por efeito de flutuação do nível do lençol freático, em condições de regime de excesso de umidade permanente ou periódico (EMBRAPA, 2006).

\section{Latossolos}

São grupamentos de solos com B latossólico. São solos com baixa capacidade de troca de cátions da fração argila. São solos, em geral, fortemente ácidos, com baixa saturação por bases ou alumínico. Sua formação é muito avançada com atuação expressiva de processos de latolização (ferralitização ou laterização), resultando em intemperização intensa dos constituintes minerais primários e secundários menos resistentes; da concentração relativa de 
argilominerais resistentes e, de óxidos e hidróxidos de ferro e alumínio, com fraca mobilização ou migração de argila, ferrólise, gleização ou plintitização (EMBRAPA, 2006).

\section{Luvissolos}

São grupamentos de solos com B textural, atividade alta da fração argila e saturação por base alta. São solos moderadamente ácidos a ligeiramente alcalinos, com teores de alumínio extraível baixo ou nulo. Sua formação vem da atuação de processos de bissialitização, conjugada a produção de óxidos de ferro e mobilização de argilas da parte mais superficial, com acumulações em horizonte subsuperficial (EMBRAPA, 2006).

\section{Neossolos}

São grupamentos de solos pouco evoluídos, sem horizonte B definido. São solos em via de formação, seja pela reduzida atuação dos processos pedogenéticos ou por características inerentes ao material originário (EMBRAPA, 2006).

\section{Nitossolos}

São grupamentos de solos com horizonte B nítido, com argila de atividade baixa ou alítica. São solos moderadamente ácido a ácidos. Sua formação pedogenética vem da atuação de ferralitização com intensa hidrolise, originando composição caulinítica-oxídica ou virtualmente caulinítica, ou com hidroxi-Al entre camadas (EMBRAPA, 2006).

\section{Organossolos}

São grupamentos de solos orgânicos. Em ambientes sujeitos a forte hidromorfismo, devido ao lençol freático permanecer elevado por grande parte do ano, as condições anaeróbicas restringem os processos de mineralização da matéria orgânica e limitam o desenvolvimento pedogenético, conduzindo à acumulação de restos vegetais. Este tipo de solo é de consttuiçao orgânica (H ou $\mathrm{O}$ ), com grande proporção de resíduos vegetais em grau variado de decomposição. Usualmente são solos fortemente ácidos, apresentando alta capacidade de troca de cátions e baixa saturação por bases. São solos que os conteúdos de constituintes orgânicos predominam em relação aos constituintes minerais (EMBRAPA, 2006). 


\section{Planossolos}

São grupamentos de solos minerais com horizonte B plânico (de permeabilidade lenta ou muito lenta), subjacente a qualquer tipo de horizonte A, podendo ou não apresentar horizonte E. É formado da desargilização vigorosa da parte mais superficial e acumulação ou concentração intensa de argila no horizonte subsuperficial (EMBRAPA, 2006).

\section{Plintissolos}

São grupamentos de solos com expressiva restrição a percolação de água (plintitização). São solos de cores pálidas, com alguns tons de alaranjado a vermelho. São solos fortemente ácidos, com saturação por bases baixa e atividade da fração argila baixa. São formados da segregação localizada de ferro, atuante como agente de cimentação, com capacidade de consolidação acentuada (EMBRAPA, 2006).

\section{Vertissolos}

São grupamentos de vertissolos. São solos de consistência muito plástica e muito pegajosa, devido à presença de argilas expansíveis ou mistura delas com outros argilominerais. Tem seu desenvolvimento restrito a grande capacidade de movimentação do material construtivo do solo em consequência dos fenômenos de expansão e contração associados à alta atividade das argilas (EMBRAPA, 2006). 
ANEXO B- Classificação dos herbicidas quanto à forma de aplicação e aos mecanismos de ação

Com relação à forma de aplicação e ao mecanismo de ação, os herbicidas podem ser classificados de acordo com Tabela 1.

Tabela 1 - Classificação dos herbicidas quanto à forma de aplicação e aos mecanismos de ação

\begin{tabular}{l|l}
\hline Classe & Descrição \\
\hline I & $\begin{array}{l}\text { Aplicados ao solo: deslocam-se das raízes para as folhas (translocadas via } \\
\text { xilema) }\end{array}$ \\
II & $\begin{array}{l}\text { Aplicados às folhas (contato): reagem rapidamente no ponto de contato e não } \\
\text { se movem nos sistemas internos das plantas (não translocados) }\end{array}$ \\
III & $\begin{array}{l}\text { Aplicados às folhas (sistêmicos): movimentam-se das folhas para os pontos de } \\
\text { crescimento das plantas (translocados via floema). }\end{array}$ \\
\hline
\end{tabular}

Fonte: Marchi, 2008.

\section{Herbicida aplicados ao solo}

Os herbicidas aplicados ao solo movimentam-se ao longo da superfície das raízes por fluxo de massa na solução do solo em resposta a transpiração (Gwynne e Murray, 1995). Além disso, movem-se por difusão e podem entrar em contato com as raízes por interceptação radicular. Esses herbicidas são translocados pelo xilema e são eficientes quando aplicados ao solo, entretanto, são utilizados também em tratamento em pós-emergência. A vantagem deste tipo de herbicida é a longa vida útil, fazendo com que estes permaneçam ativos no solo até que sejam degradados; são fáceis de aplicar, na forma granulada ou pulverizada (Gwynne e Murray, 1985).

Entretanto, a efetividade desses herbicidas depende do teor de agua do solo, ou seja, a falta de umidade torna o processo menos efetivo, pois a dissolução na solução do solo é pequena e consequentemente os torna indisponível para as plantas (Gwynne e Murray, 1985). 


\section{Herbicidas aplicados às folhas (herbicidas de contato)}

Os herbicidas de contato são preferidos aos sistêmicos por matarem as plantas invasoras muito rapidamente e como não serem persistentes, uma cultura pode ser plantada logo após o tratamento. A maioria destes herbicidas funciona destruindo a membrana celular. A desvantagem é que uma boa cobertura das plantas invasoras pelo jato aplicador é fundamental. Em geral, somente algumas plantas invasoras anuais são controladas, ao passo que plantas perenes com raízes profundas não morrem, pois a ação do herbicida atinge somente a parte aérea das plantas, enquanto a porção subterrânea fica inalterada e pode dar início a um novo ciclo de crescimento (Gwynne e Murray, 1985; Peterson et al, 2001).

Esses herbicidas são mais efetivos em plantas invasoras de folha larga em relação as gramíneas, pois o ponto de crescimento das gramíneas jovens está no verticilo, ponto de difícil acesso por meio de aplicação de herbicida. Em contraste, o ponto de crescimento das plantas de folha larga é mais fácil de ser atingido pelo jato de aplicação do herbicida (Peterson et al, 2001).

\section{Herbicidas aplicados às folhas (sistêmicos)}

Os herbicidas sistêmicos causam efeito fitotóxico por penetração na cutícula (membrana cerosa, repelente à agua). Há três rotas nas quais os herbicidas podem se difundir através da cutícula para chegar às células: por meio dos poros da cutícula, para herbicidas solúveis em agua (apolares); uma rota para os polares e uma rota pelo ectodesma, para todos os herbicidas (Gwynne e Murray, 1985).

Após a penetração pela cutícula das folhas, os herbicidas sistêmicos precisam ganhar acesso ao sistema de transporte de longa distância do floema para atingir áreas remotas do local de contato de sua aplicação. Porém os compostos sistêmicos se movimentam pelo floema e também pelo xilema (Vidal, 1997). O xilema é um tecido morto pelo qual a planta transporta água e nutrientes absorvidos pela raiz para as partes aéreas. O floema é um tecido vivo no qual fotossintatos e outras substâncias se movem nos dois sentidos. O floema transporta fotoassimilados que são produzidos nas folhas para as raízes e para as áreas de crescimento (Peterson et al, 2001). 


\section{Mecanismos de ação dos herbicidas \\ Inibidores da enzima Acetil Coenzima-A Carboxilase (ACCase)}

Estes herbicidas têm efeito sobre espécies da familia Poaceae (gramíneas) e seletivos para várias espécies dicotiledôneas. A ACCase é uma enzima-chave na síntese de lipídios, componentes importantes de estruturas como a membrana celular. Após a aplicação, nota-se a paralização do crescimento, descoloração dos pontos de crescimento e clorose das folhas jovens. Folhas mais velhas podem ficar arroxeadas, alaranjadas ou vermelhas (Fontes, 2003). Os principais compostos com capacidade de inibir a enzima ACCase são:

- Arifenoxipropiantos: diclofop, fenoxaprop, fluazifop, haloxyfop, propaquizafop, quizalofop;

- Ciclohezanodionas: butroxydin, clethodin, sethoxydim, tepraloxydim.

\section{Inibidores da enzima Acetato Lactatosintase (ALS)}

Estes herbicidas têm efeito, principalmente, sobre espécie dicotiledôneas. Algumas imidazolinonas têm efeito sobre as gramíneas e algumas sulfoniluréias sobre ciperáceas. A ALS é uma enzima importante na síntese de alguns aminoácidos (leucina, valina e isoleucina). Alguns dias após a aplicação percebe-se a paralisação do crescimento, descoloração das folhas jovens, necrose de nervuras e dos pecíolos e queda de folhas. As raízes das plantas crescem pouco e as raízes secundarias são curtas (Fontes, 2003). Os principais herbicidas com capacidade inibitória da ALS são:

- Imidazolinonas: imazamox, imazapyr, imazapic, imazaquin, imazethapyr;

- Sulfoniluréias: azinsulfuron, chlorimuron, flazasulfuron, halosulfuron, metsulfuron, nicosulfuron, oxasulfuron, pyrazosulfuron;

- Sulfoanilidas: cloransulam, diclosulam, flumetsulam. 


\section{Inibidores da enzima 5-enolpiruvilshiquimato-3-fosfatosintase (EPSPs)}

Os herbicidas pertencentes a esse grupo têm efeito sobre espécies monocotiledôneas e dicotiledôneas e não são seletivos, exceto à soja tolerante ao glifosato. A EPSPs é uma enzima importante na síntese de alguns aminoácidos (fenilalanina, tirosina e triptofano). O herbicida tem efeito rápido, paralisando o crescimento da planta. Dentre os sintomas apresentados estão a clorose dos pontos de crescimento e das folhas jovens, que dentro de três semanas se tornam necrosadas (secas) (Fontes, 2003). Os principais herbicidas desse grupo são o glifosato e o sulfosato.

\section{Hormônios ou reguladores de crescimento}

Estes herbicidas têm efeito sobre espécies dicotiledôneas e são seletivos para gramíneas. Eles provocam um desbalanço na atividade hormonal da planta sensível causando crescimento desordenado dos tecidos vegetais. Os sintomas mais comuns são a curvatura ou enrolamento do ápice da planta (epinastia), espessamento do caule e do pecíolo. A planta morre por volta de quatro a cinco semanas após aplicação (Fontes, 2003). Os principais herbicidas hormonais são:

- Dicamba (derivado do ácido benzoico);

- 2,4-D (derivado do ácido fenoxiácetico);

- Fluroxipyr, picloran, triclopyr (derivados do ácido picolínico) e o quinclorac.

\section{Inibidores do fotossistema I}

Estes herbicidas controlam espécies mono e dicotiledôneas e são não seletivos. Interrompem o transporte de elétrons no processo fotossintético e impedem a produção de energia aos processos metabólicos da planta. Os principais sintomas são a murcha e a necrose da planta, horas após a aplicação (Fontes, 2003). Os herbicidas inibidores de fotossistema I são diquat e o paraquat.

\section{Inibidores do fotossistema II}

Estes herbicidas controlam plantas invasoras dicotiledôneas e são seletivos para culturas mono e dicotiledôneas. Interrompem o fluxo normal de elétrons durante o processo 
fotossintético provocando uma sobrecarga nas moléculas de clorofila. Os principais sintomas são: a descoloração das folhas, surgimento de manchas aquosas e posterior necrose. A planta morre dentro de cinco dias após aplicação (Fontes, 2003). Os principais herbicidas inibidores do fotossistema II são: as triazinas (ametrin, atrazina,...); as uréias substituídas (diuron, linuron,...); as uracilas (bromacil) dentre outros.

\section{Inibidores da enzima protoporfirinogênio oxidase (PROTOX)}

Estes herbicidas controlam plantas invasoras dicotiledôneas em várias culturas, em especial o feijão e a soja. A enzima protorfirinogênio oxidase está envolvida na síntese de clorofila. A inibição desta enzima leva ao acumulo de protoporfirinogênio, que em níveis elevados passa interagir com o oxigênio formando radicais livres que causam a peroxidação de lipídios de membranas celulares. Os principais sintomas são: a descoloração das folhas com posterior necrose, levando a planta à morte em poucos dias (Fontes, 2003). Os herbicidas inibidores da PROTOX são: as difeniléteres; as ftalimidas e as triazolinonas.

\section{Inibidores da síntese de caroteno}

Estes herbicidas controlam espécies monocotiledôneas e dicotiledôneas anuais e algumas perenes. Eles atuam interferindo na rota metabólica de terpenóides, essenciais na síntese de vários outros compostos, entre eles os carotenos. Eles protegem as clorofilas do excesso de energia. Os principais sintomas apresentados são o branqueamento da planta quando emerge do solo e, posteriormente necrose e morte (Fontes, 2003). Os principais herbicidas inibidores da síntese de caroteno são o clomazone, o isoxaflutole e o norflurazon.

\section{Inibidores de divisão celular}

\section{Inibidores de crescimento da parte aérea}

Estes herbicidas controlam gramíneas e algumas dicotiledôneas. Têm efeito negativo no desenvolvimento das plantas devido a eventos como: inibição da síntese de lipídios, elongação celular, síntese de alguns hormônios, flavonóides e proteínas. As sementes das espécies sensíveis germinam, mas grande parte das plântulas não emergem. Os sintomas são: folhas retorcidas com coloração verde-escura intensa. Nas dicotiledôneas, as folhas apresentam 
encurtamento da nervura central e depressão nas pontas (Fontes, 2003). Os principais herbicidas são: as amidas (acetochlor, alachlor, metalachor, ...)

\section{Inibidores de crescimento de raízes}

Estes herbicidas controlam espécies gramíneas e algumas dicotiledôneas. O mecanismo de ação desses herbicidas é a inibição da síntese de tubulina, proteína importante no processo de divisão celular. A tubulina é responsável pela separação dos cromossomos durante a divisão celular. Os sintomas são encurtamento e espessamento da raiz principal, sem a formação de raízes secundárias, que acarretam no atrofiamento da parte áreas da planta (Fontes, 2003). Os herbicidas inibidores da síntese da tubulina são o oryzalin, o trifluralin, o pendimethalin e o thiazopyr.

\section{Inibidores da enzima glutamina sintetase (GS)}

A glutamina sintetase é uma enzima-chave no processo de incorporação de amônia nos tecidos vegetais. Ela promove a união da amônia e do glutamato formando a glutamina, composto precursor de vários aminoácidos. Os sintomas são a murcha e a clorose da planta, que posteriormente levam a necrose intensa e morte (Fontes, 2003). O herbicida pertencente a esse grupo é o amônio-glufosinato. 